\title{
Vader, raadgever en beschermer : Petrus Regout en zijn arbeiders 1834-1870 : stijlen van werving, behoud en beheersing van arbeid in fabrieksregimes in de beginjaren van de Westeuropese Industriele Revolutie
}

Citation for published version (APA):

van Iterson, A. T. M. (1992). Vader, raadgever en beschermer : Petrus Regout en zijn arbeiders 18341870 : stijlen van werving, behoud en beheersing van arbeid in fabrieksregimes in de beginjaren van de Westeuropese Industriele Revolutie. [Doctoral Thesis, Maastricht University]. Datawyse / Universitaire Pers Maastricht. https://doi.org/10.26481/dis.19920626ai

Document status and date:

Published: 01/01/1992

DOI:

10.26481/dis.19920626ai

Document Version:

Publisher's PDF, also known as Version of record

Please check the document version of this publication:

- A submitted manuscript is the version of the article upon submission and before peer-review. There can be important differences between the submitted version and the official published version of record. People interested in the research are advised to contact the author for the final version of the publication, or visit the DOI to the publisher's website.

- The final author version and the galley proof are versions of the publication after peer review.

- The final published version features the final layout of the paper including the volume, issue and page numbers.

Link to publication

\footnotetext{
General rights rights.

- You may freely distribute the URL identifying the publication in the public portal. please follow below link for the End User Agreement:

www.umlib.nl/taverne-license

Take down policy

If you believe that this document breaches copyright please contact us at:

repository@maastrichtuniversity.nl

providing details and we will investigate your claim.
}

Copyright and moral rights for the publications made accessible in the public portal are retained by the authors and/or other copyright owners and it is a condition of accessing publications that users recognise and abide by the legal requirements associated with these

- Users may download and print one copy of any publication from the public portal for the purpose of private study or research.

- You may not further distribute the material or use it for any profit-making activity or commercial gain

If the publication is distributed under the terms of Article $25 \mathrm{fa}$ of the Dutch Copyright Act, indicated by the "Taverne" license above,

Download date: 26 Apr. 2023 
VADER, RAADGEVER EN BESCHERMER

PETRUS REGOUT EN ZIJN ARBEIDERS 1834-1870 



\section{VADER, RAADGEVER EN BESCHERMER PETRUS REGOUT EN ZIJN ARBEIDERS 1834-1870}

Stijlen van werwing, behoud en beheersing van arbeid in fabrieksregimes in de beginjaren van de Westeuropese Industriële Revolutie

\section{PROEFSCHRIFT}

ter verkrijging van de graad van doctor aan de Rijksuniversiteit Limburg, op gezag van de Rector Magnificus, Prof. mr M.J. Cohen, volgens het besluit van het College van Dekanen, in het openbaar te verdedigen op vrijdag, 26 juni 1992 om 14.00 uur

door

Andreas Theodorus Marie van Iterson.

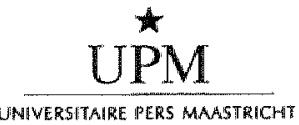


Promotor:

Beoordelingscommissie: Prof. dr A.M. Sorge (voorzitter)

Dr P.K. Keizer

Prof. dr C.J. Lammers (Rijksuniversiteit Leiden)

Prof. dr J.H.R. van de Poel

Prof. dr A.C. Zijderveld (Erasmusuniversiteit

Rotterdam)

Iterson, Andreas Theodorus Marie Van

Vacer", raadgever en beschermer : Petrus Regout en zijn arbeiders 1934-1970: stijlen var werving behoud en beheersing van arbeid in fabrieksregimes in de beginjaren van de westeuropese Industriele Revolutie / Andreas

meodorus Marie van Itercon. - Mastricht : Universitaire Pers Mastricht

proefschrift Mastricht. - Met lit. opg. - Met samenvattirg in her Engels.

$\operatorname{Ts} \operatorname{sen} 90-5278-030-7$

I'retw. Regout, Petrus Dominicus/Limburg; sociad-economische geschiedenis: 190 eeuw industriadisatie : west-Europa ; geschiedenis.

(c) Ad van Iterson, Maastricht

Grafische vormgeving: J. Hulscher, Berchem

Omslag: Geert Setola, Oirsbeek

Druk: DATAWYSE I Universitaire Pers Maasticht 


\section{INHOUDSOPGAVE}

0. VOORWOORD wii

1. INLEIDING 1

2. HET GEVAL: DE GESCHIEDENIS VAN DE GLAS-, KRISTALEN AARDEWERKFABRIEKEN VAN PETRUS REGOUT

3. DE CONTEXT: INDUSTRIELE REVOLUTIE EN INDUSTRIALISERING IN WEST-EUROPA

$\begin{array}{ll}3.0 \text { Inleiding } & 29\end{array}$

3.1 De Industriële Revolutie in Engeland 31

3.2 De Industriële Revolutie op het continent 35

3.3 De Industriële Revolutie in de Lage Landen:
de ongelijke verdeling

3.4 De stedelijke context:

de Industriële Revolutie in Maastricht

4. PROBLEMEN VAN WERVING, BEHOUD EN BEHEERSING VAN ARBEID IN HET MODERNE FABRIEKSSYSTEEM

IN DE EERSTE DECENNIA VAN DE

INDUSTRIELE REVOLUTIE

4.1 De geboorte van het fabriekssysteem

4.2 Problemen van werving, behoud (en kosten) van (geschoolde en ongeschoolde) (mannelijke, vrouwelijke en minderjarige) arbeid

4.3 Problemen van beheersing:

het disciplineren en coördineren van arbeidskrachten

4.4 Problemen van werving, behoud en beheersing als dimensies

4.5 Stijlen van werving, behoud en beheersing

4.6 Twee ideaaltypen van wervings-, behoud-en beheersingsstijlen: de paternalistische en de liberale stijl

4.7 Legitimering van stijl 
5. DE STIJL VAN PETRUS REGOUT

5.1 Wervings-, behoud - en beheersingsstijl in de fabrieken van Petrus Regout

5.2 Arbeiderswoningbouw door Petrus Regout: de 'Cité Ouvrière' in de Sint-Anthoniusstrat

5.3 Regout's 'Cité Ouvrière' als legitimerend symbolisch artefact

5.4 Legitimering door idealisering: Regout's publicaties over het 'Pauperisme-vraagstuk'

6. TOT SLOT

LITERATUUR 


\section{VOORWOORD}

De reis die 'proefschrift schrijven' heet, is eenzamer dan de gebruikelijke dankwoorden suggereren. Toch moet ik, bij de eindbestemming terugkijkend, tot mijn vreugde constateren dat ik op menige viersprong door wijze en hartelijke mensen de weg ben gewezen. Zij verdienen dank en dat krijgen ze ook. Op de eerste plaats noem ik mijn promotor, prof. dr Geert Hofstede. Hij heeft me aangeleerd hoe je structuur in onderzoek en verslaglegging kunt aanbrengen en afgeleerd de lezers te vervelen met te veel nescio's en relativeringen.

Voorts wil ik leden van de beoordelingscommissie bedanken: prof. dr A.M. Sorge (voorzitter), dr P.K. Keizer, prof. dr C.J. Lammers, prof. dr J.H.R. van de Poel en prof. dr A.C. Zijderveld. Ik bedank ook alle anderen met wie ik over mijn onderwerp heb gepraat of die mij met commentaar hebben verblijd. Ik noem - met excuses voor wie ik per abuis oversla - : prof. dr Anton Blok, Willem Buyink lic., drs. Bas van Diepen, prof. dr Norbert Elias ( $t$ ), prof. dr Johan Goudsblom, drs Paul Kunst, prof. dr A.J.J. Mekking, drs René Olie, drs Sjoerd Romme, drs Eugène Schenk, prof. dr Hein Schreuder, dr Sjo Soeters, drs Tom van Veen, prof. dr Arjen van Witteloostuijn en drs Geert Woltjer. Dank ook aan Anne-Wil Harzing, Jolanda Koetsier, Aad van Mourik, Geert Setola en Mieke van Zutphen voor hun bijgedragen in de facilitaire sfeer. Verder wil mw. A. Knoups, public relations manager van de NV Koninklijke Sphinx, bedanken, die de archieven van het bedrijf voor me opende en me daarmee de ontdekking van mijn leven schonk: het contract dat de hoofdpersoon van mijn proefschrift, Petrus Regout, heeft afgesloten met meester metselaar Haenen uit Lanaken voor het bouwen van de beroemde cité ouvrière in de St.-Anthoniusstraat. Omdat de aannemer niet kon schrijven, waren twee buitenstaanders erbij gehaald die met hun handtekening getuigden dat het kruisteken onder het contract daadwerkelijk van meester metselaar Haenen uit Lanaken was. De ene getuige was een schipper uit Utrecht, die ongetwijfeld met zijn schip aan de overkant van de fabriek in het Bassin lag; de andere was mijn betovergrootvader Elias Roessingh van Iterson, die netjes in het vage ten tonele wordt gevoerd als 'de Heer... etc.', terwijl de schipper bij zijn beroep wordt genoemd. Van de 30 à 40.000 inwoners die Maastricht in 1855 telde, was de opa van mijn opa degene die over de Boschstraat liep toen Regout's boekhouder naar buiten kwam om iemand met een deugdelijke handtekening te vinden. Of zat hij met de Utrechtse schipper in het café? En kregen de twee een borrel voor de dienst die van hen werd gevraagd? (voor een uitgebreider verslag zie: Maastricht in dertig polemieken, Maastricht: Studium Generale, 1992: 78-81).

Tot slot bedank ik - nee, niet mijn vrouw Christiane en mijn kinderen Elise, Emma, Albertine en Louis. Dat heeft de eerste mij verboden en ik deel haar bezwaren tegen dit paternalistisch wetenschapsritueel: 'papa heeft jarenlang geen goeie papa kunnen zijn omdat hij moest promoveren, 
viii

maar vanaf nu zal hij alle tijd voor jullie hebben'. Wie zóveel moeite heeft met het schrijven van een bock, kan beter een ander vak kiezen. Maar ik noem wel mijn moeder. Om mij te laten studeren heeft zij zich heel wat moeten ontzeggen. Aan mijn veel te vroeg overleden vader draag ik dit boek op.

Maastricht, 26 april 1992 


\title{
HOOFDSTUK 1
}

\author{
INLEIDING
}

Deze studie is begonnen met de waarneming van een beeld. Op de omslag van The making of the English working class van de sociaal-historicus E.P. Thompson (1980) staat een afbeelding van een mijnwerker uit Costumes of Yorkshire, 1814 van G. Walker (British Museum, Londen). Deze 'Yorkshire collier' is een man van onbestemde leeftijd, een pijpje in de mond, een lichtblauwe sjaal om de hals, op zijn hoofd een vilten hoed met slappe randen. In zijn rechterhand houdt hij een lange wandelstok; aan zijn linkerarm hangt een rieten mandje. Op de achtergrond rijdt een stoomlocomotief voorbij die een aantal wagens trekt. Nog verder op de achtergrond is een heuvel, met bovenop een huisje, dat de suggestie wekt de verblijfplaats van de man te zijn.

De blik van de man is goedmoedig, onbewolkt, argeloos en bovenal ruraal. Wat bracht hem ertoe de heuvel af te dalen? Wat weerhield hem ervan de heuvel weer te beklimmen? Wat werd met hem gedaan daar beneden, wat probeerde men van hem te maken? Uit deze vragen vloeide een nieuwe voort: wie waren de mensen die deze onschuldige ziel trachtten binnen te halen, te behouden en te beheersen?

Wat moet een industrieel ondernemer kunnen? In bedriffseconomische leerboeken vindt men doorgaans als antwoord het volgende rijtje: a) initieel kapitaal vergaren; b) markten ontdekken, penetreren en zich erop handhaven; c) produkten ontwikkelen waarnaar vraag bestaat dan wel kan worden gecreëerd; d) een produktieproces ontwerpen en bewaken; e) technische vernieuwingen op hun waarde schatten en inpassen in het produktiesysteem; f) werkkrachten werven, behouden ${ }^{2}$ en motiveren of beheersen.

"In A.D. de Groot's standaardwerk Methodologie (1961) is 'waarneming' de eerste fase in de empirische cyclus bij het wetenschappelijk denken (pp. 1-9); in deze fase worden uitspraken op een laag algemeenheidsniveau tentatief geformuleerd. Op waarneming volgen 'vermoeden', 'verwachten', 'toetsen' en 'evalueren'.

2 Het afvoeren ('lozen') van werkkrachten zal men in deze leerboeken vergeefs zoeken. Ook in deze studie wordt weinig aandacht besteed aan het beëindigen van de werkrelatie van de kant van de fabrikant. Ik hoop dit verzuim in een latere publikatie goed te maken. 
Dit proefschrift gaat over $f$ ). Maar dan $f$ in een quasi-experimentele situatie: in de beginjaren van de Westeuropese Industriële Revolutie toen de problemen van werven, behouden en beheersen nog nieuw waren - althans in deze vorm en omvang - en fabrikanten nog niet of nauwelijks beproefde recepten konden gebruiken.

In zijn klassieke studie Der moderne Kapitalismus uit 1921 schrijt de socioloog Wemer Sombart dat de essentiële kenmerken van het kapitalisme het winstmotief en rationaliteit zijn. Wat een ondernemer in eerste instantie moet kunnen, is calculeren en sparen. Sombart's visie op de kapitalistische ondernemer is een heldere, maar beperkte. De industriële entrepreneur, ten minste, moest niet alleen zichzelf scholen en leren beheersen, opdat hij kon calculeren en sparen, maar ook anderen: de mensen die de 'produktiefactor arbeid' worden genoemd.

Beheersing van grondstoffen, van kapitaal, van arbeid, van produktieprocessen, van kwaliteit en kwantiteit, en ook van de externe omgeving: markten, belanghebbenden en instituties - al deze wijzen van beheersing vormen samen een hoofdtaak wan entrepreneurs en managers. '[..] [C]ontrol is indeed the central concept of all management systems, as has been recognized implicitly or explicitly by all theoreticians of management (1974: 68), stelt Harry Braverman in Labor and Monopoly Capital. Hij haalt daarbij Leffingwell (1925) aan: 'Effective management implies control. The terms are in a sense interchangeable, as management without control is not conceivable."

Decennia vóór de zegetocht van het scientific management, de organisatietheoretische methode die dienst deed als een vehikel voor gestage vergroting van de beheersing ${ }^{3}$ van de interne bedrijfswereld (bv. Braverman, 1974: 90-914; Coriat, 1981: 12 \& 39; en andere schrijvers uit de anti-kapitalistische traditie, die vaak eerder van onderwerping - Coriat, p. 26 - dan van beheersing spreken), zagen industriële pioniers zich voor de opgave gesteld (nieuwe) arbeiaskrachten te werven, behouden, coördineren en disciplineren. Daarbij stonden hun geen wetenschappelijke 'rationele' modellen ten dienst. De enige voorbeelden waarnaar men zich kon richten waren i) de traditionele oplossingen van de (vaak kleinschalige) pre-

${ }^{3}$ Om tot een eerste afbakening van beheersing (van organisaties) te komen volgt hier een handboekdefinitie: 'Beheersing is het proces waarbij managers beinwloeden of bepalen wat de leden van de organisatie doen, temeinde de doelen van de organisatie te kumnen realiseren' (Kunst et al. 1991: 72)

${ }^{4}$ Een citaat: 'Control has been the essential feature of management throughout its history, but with Taylor it assumed unprecedented dimensions' (p. 90 ) 
modeme produktie-bedrijven en ii) de traditionele instituten van het leger, het klooster, de gevangenis en het arm- en wezenhuis (vgl. Foucault, 1977), maar in deze laatste organisaties speelde produktie een ondergeschikte rol. ${ }^{5}$ En wat andere industriêle entrepreneurs reeds hadden ontwikkeld, werd of uit angst en behoudzucht niet meteen overgenomen of was niet terstond beschikbaar: pas toen, na opheffing van het Britse verbod op uitvoer van expertise, in de jaren twintig van de negentiende eeuw enkele duizenden Engelse technici en geschoolde arbeiders als adviseur naar het continent trokken, konden nieuwe technieken (en naar men mag aannemen ook nieuwe managementtechnieken ${ }^{6}$ ) door de meest ambitieuze fabrikanten worden overgenomen.

Via de Yorkshire collier ben ik geboeid geraakt door, wat badinerend werd genoemd, de schoorsteenaristocraten. De Industriële Revolutie is geschapen door - en schiep - een nieuwe klasse van ondernemers. De opkomst van deze klasse had een drastische wijziging in bestaande machtsongelijkheden tot gevolg. Het betekende het einde van de hegemonie van de landadel, die vooral op het continent onaantastbaar leek; - het betekende ook dat de overheidspolitiek meer en meer werd bepaald door de belangen van fabrikanten en hun kapitaalverstrekkers; - dat deze opkomende elite zich via huwelijken en vrijblijvender allianties vermengde met gevestigde elites; - dat de stille deugden (die met name in de middeleeuwse kloosters werden ontwikkeld tot praktijken) en de ridderlijke deugden van trots en eer grotendeels weken voor de rationalistische godsdienst van streven en werken ${ }^{7}$; - het betekende ten slotte ook dat grote groepen mensen door deze nijvere strevers binnen de fabrieksmuren werden gehaald en gehouden, en gekneed tot een werk- en leefritme waaraan ze niet gewend waren.

De schoorsteenaristocraten zijn, zonder dat ze dat nu voor ogen hadden, belangrijke medescheppers van de welvarende en pluriforme Westerse samenlevingen geworden. Hun rationaliteit (aanpassing van de middelen aan het doel) en hun eerzucht (ambitie om dat doel te bereiken) maakten dat ze als winnaars (zo niet morele, dan toch materiële) te voorschijn kwa-

5 Duidelijker misschien dan in de structurering van het werk kan men in de architectuur en layout van de fabrieken elementen van kazernes en kloosters herkennen. Fabrikanten hadden geen tijd om op een eigen fabrieksarchitectuur te wachten.

6 Vgl. Kemp die spreekt van '[..] a diffusion of technology and organizational forms from Britain to the Continent [...]" (1984: xi).

${ }^{7}$ De vroeg-negentiende-eeuwse conservatieve denker Thomas Carlyle sprak van een Religion of Work. 
men uit deze grote omwenteling en Umwerturng die ruwweg tussen 1750 en 1900 in West-Europa (maar ook elders) heeft plaatsgevonden. Op rationaliteit kan men zich met goed fatsoen laten woorstaan; zelfs de extreme romantici erkennen de waarde van een rationele benadering. Maar eerzucht is nog steeds omstreden, zelfs in de competitieve jaren tachtig en negentig van deze eeuw. Daarom was (en is) het vooral de ambitie van fabrikanten die legitimering vorderde (vordert). De buitenwereld vroeg erom, de fabrikanten voelden het. Ik zal hier vooral aandacht hebben voor de legitimering van de ambitie om anderen naar een systeem van moderme industrièle produktie te voegen.

Mijn vermoeden en verwachting was dat ook in het rationeel en eerzuchtig streven van fabrikanten de mogelijkheden bestonden om (consistente) accenten te leggen. Dat heb ik hier proberen te toetsen. In één zin samengevat luidt het argument ${ }^{8}$ van deze studie: bij het werven, behouden en beheersen van arbeid ${ }^{9}$ in de beginjaren van het moderne fabriekssysteem bestond er voor fabrikanten als Petrus Regout ruimte om een specifieke stijl aan te wenden - een stipl die zich onder meer kenmerkte door ambigue drijfveren, hetgeen weer de behoefte vergrootte deze stijl te legitimeren.

De negentiende-eeuwse fabriek lijkt niet de meest geschikte lokatie om 'stijl' een rol te laten spelen. Misschien vindt iemand het ongepast: zo'n frivool begrip toe te laten waar zoveel is geleden onder uitbuiting en onderdrukking - in de "gematigde tuchthuizen', zoals de Franse utopisch socialist Charles Fourier fabrieken noemde, in het bagno in mildere vorm", zoals de Duitse econoom/socioloog Karl Marx het formuleerde, in

${ }^{8}$ In dit proefschrift heb ik eerder bestaande kennis in een nieuw verband proberen te presenteren dan deze kennis wit te breiden. Het meeste materiaal is al uit de archieven en andere vindplaatsen opgediept en gepubliceerd. Betreffende de glas-, kristal- en aardewerkfabrieken van de Petrus Regout is A.J.Fr. Maenen's proefschrift, Perns Regout 1801-1878 (1959) een gedegen (bedrijfs)historische bron. Er is als bezwaar aangetekend dat deze bedrijfsgeschiedenis (overigens één van de weinige in Nederland) een sterk apologetisch karakter heeft. Dat valt moeilijk te loochenen, maar het laat, in dit geval, de nauwkeurigheid in de behandeling van de primaire bronnen onverlet. Ik heb, ter verifiëring en verdieping, een deel wan het bedrijfsarchief van de NV Koninklijke Sphinx bestudeerd en werd keer op keer getroffen door Maenen's correcte weergave en parafrasering van de documenten.

9 Arbeid die niet direkt aan de produktie kan worden gerelateerd, zoals het werk van kantoorbeambten en agenten, laat ik buiten beschouwing. Maar ook chefs (opzichters en hoofdopzichters) zullen hier grotendeels onbesproken blijven (zie voor enige opmerkingen over zowel kantoorbeambten als opzichters in Regout's fabrieken: Maenen, 1959: 359-364). 
het "moordhol", zoals Petrus Regout's fabrieken zijn genoemd.

'Stijl' wordt in eerste instantie geassocieerd met kunst, sport en amusement. Aan geleerden en wetenschappelijke scholen wordt ook wel een bepaalde stijl toegeschreven. Als heuristisch concept bij de bestudering van organisaties doet het begrip pas de laatste decennia opgang. Denk aan: 'managementstijlen' (bv. Peters \& Waterman, 1982), 'leiderschapsstijlen' (voor een overzicht zie: McCall, 1983), 'stijl van bedrijfsvoering', enz. 'Stijl", in deze $z$ in, betreft dan ook aktiviteiten van managers van moderne organisaties.

'Stijl' en 'negentiende-eeuwse fabrikanten', daarentegen, lijken onverenigbaar, of temminste ongepast. Maar daar staat tegenover dat een begrip dat doorgaans wordt gehanteerd in een andere (hier: hedendaagse) context een nieuw licht kan werpen op een probleem. Deze vorm van surrealistische techniek - want zo zou men het kunnnen bestempelen - wordt door de kunsthistoricus Kenneth Burke genoemd het "perspectief door onverenigbaarheid' (aangehaald in Gouldner, 1973: 17, de Amsterdamse oratie van deze Amerikaanse socioloog): 'stijl' en 'negentiende-eeuwse fabrikanten' openen, op elkaar betrokken, misschien een nieuw perspectief. Vergelijk ook Alvin Gouldner's eigen opmerking dat '[..] begrip voor en inzicht in een bepaald deel van de samenleving kan worden verkregen door dit deel te bezien vanuit een ongewoon en onverwacht standpunt' (ibid., p. 17). Een souteneur beschouwen als een 'gewone' handelaar, het afwijkende op één lijn stellen met het respectabele, zoals men in de Chicago School (de sociologische) heeft gedaan, is een voorbeeld van het hanteren van het perspectief door onverenigbaarheid. Het toepassen van het agentprincipaalmodel ${ }^{10}$ op criminele praktijken is een ander voorbeeld. Met het introduceren van de begrippen wervingsstijl, behoudstijl en beheersingsstijl wil ik bij deze traditie aansluiten.

De Industriële Revolutie wordt vaak samengevat in een aantal technische veranderingen: vervanging van menselijke vaardigheden door mechanische apparaten; vervanging van menselijke en dierlijike kracht door levenloze kracht, in het bijzonder stoom; een duidelijke vooruitgang in het vinden en exploiteren van grondstoffen, in het bijzonder in de metaal-en

10 Het agent-principalmodel, dat in de valgende hoofdstukken een parar keer te hulp wordt geroepen, heeft betrekking op de coördinatie- en controleproblemen die kunnen optreden als een (economische) actor (de principaal) werkzamheden delegeert aan een andere (de agent), terwijl de eerste de gangen van de tweede niet volledig kan nagaan. In de agency-theorie, zoals dit model wordt genoemd, zijn de belangrijkste problemen: informatie-onzekerheid, informatieasymmetrie (de ene partij weet meer dan de andere) en het 'shirking'-probleem (het zich-drukken van de agent). Voor een overzicht van de theorievorming rondom deze begrippen, zie bijvoorbeeld: Van de Poel, 1986: 116-126. 
de chemische industrie. Niet minder essentieel zijn de veranderingen in organisatie van deze produktie, die parallel aan deze technische veranderingen optraden. Machines en stoomkracht vereisten - en maakten mogelijk - concentratie van fabricage. Daardoor namen de produktie-eenheden in omvang toe. De werkplaats en werkkamer maakten plaats voor de fabriek. Maar er traden ook grote veranderingen in taken en bevoegdheden van de deelnemers in het produktieproces op. Aan de ene kant was er de industriële entrepreneur, die niet alleen arbeiders in dienst nam en het produkt op de markt bracht, maar ook de kapitaalgoederen inbracht en bewakte en daardoor ongekende (financiële) risico's liep. Aan de andere kant stonden de arbeiders, vrijwel allemaal beroofd van het eigendom van de produktiemiddelen en in meerderheid gereduceerd tot de positie van, zoals het in het Engels heet, "hand" - helpende hand. ${ }^{11}$ Wat beide partijen bij elkaar bracht en hield, was i) een marktrelatie, die onder andere uitdrukking vond in het arbeidsloon, en ii) een hiërarchische relatie, die onder andere uitdrukking vond in coördinering en disciplinering. In dit proefschrift probeer ik de verwevenheid van beide relaties -'markt' en 'hiërarchie' - te verkennen, te weten: uit het gezichtspunt van de werkgevende partij.

Mijn keuze voor de glas-, kristal- en aardewerkfabrieken van Petrus Regout (1801 - 1878) in Maastricht als historische casus ${ }^{12}$ vraagt motivering. De Amerikaanse econoom met Nederlandse wortels Joel Mokyr spreekt van een 'fascinating case' (1976: 121). Dat is waar en dat heeft

${ }^{11}$ Het zijn vooral de marxistische of door Marx geïnspireerde auteurs die op deze reductie de nadruk leggen. Zoals Braverman: 'The early phases of industrial capitalism were marked by a sustained effort on the part of the capitalist to disregard the difference between labor power and the labor that can be gotten out of it, and to buy labor in the same way he bought his raw materials: as a definite quantity of work, completed and embodied in the product' (1974: 60). Andere auteurs hebben gewezen op het voordeel van specialisatie. Zo stelt Mckendrick met betrekking tot de arbeiders in Wedgwood's aardewerkfabriek Etruria: "Division of labour did not destroy skill; it limited its field of expression to a particular task, but within those limits it increased it [..]' (1966: 67). Maar deze aanspraak betreft slechts een minderheid van de arbeiders.

12 Over de problematiek van case studies en hun generaliseerbaarheid zie de klassieke methodische bespiegelingen in Lipset et al. (1956). Yin (1984) maakt een verhelderend onderscheid tussen statistische en theoretische generaliseerbaarheid. Bij het eerste generaliseert men gevonden frequenties naar een hele populatie of heel universum; bij het tweede ontwikkelt men inzichten die elders, in ongelijksoortige 'gevallen', toepasbaar kumnen zijn. In de menswetenschappen ziet Yin alleen mogelijkheid voor de tweede soort generalisatie (zie ook: Van Iterson, 1987a, 1990). 
meegespeeld. Maar er is méér, want er is zoveel dat fascineert.

Zoals de Industriële Revolutie een van de belangrijkste keerpunten van de geschiedenis van de mensheid was, was de komst van de glas- en aardewerkindustrie in Maastricht een keerpunt in de geschiedenis van deze stad: een moment vanaf welk de samenlevingsverbanden een andere structuur krijgen. ${ }^{13}$ In de wereld zowel als in Maastricht bleek de Industriële Revolutie als Adam's proeven van de appel: een gebeurtenis waarna alles er volkomen anders kwam uit te zien. Ook vór de komst van de econoom Joseph Schumpeter was het bekend dat verandering schept èn vernietigt. De Industriële Revolutie heeft veel mensen veel ellende gebracht: van vervreemding tot vroegtijdige dood. Maar het alternatief géén modernisering - had waarschijnlijk nog rampzaliger uitgepakt: zie Ierland, dat door armoe en honger geteisterd leegstroomde.

"Als niet door de energie van mijn vader fabrieken in Maastricht waren opgericht, dan zou men eens zien wat een armzalig plaatsje Maastricht zou wezen,' zei Eugène Regout (één van Petrus' zonen en opvolgers) tegen de commissie van de Parlementaire Enquête van 1887 (vraag 7360; in: Giele, 1981). De antwoorden die Regout's zonen op vragen van de commissie hebben gegeven, zijn berucht geworden als cynische uitingen van harde liberale fabrikanten, maar deze opmerking bevat veel waarheid.

Het is hier niet de bedoeling om een winst- en verliesrekening op te maken van Maastricht's vroege industrialisering. De constatering volstaat dat Regout's aktiviteiten iedere Maastrichtenaar hebben beroerd, zij het in verschillende mate. Ook de Maastrichtenaar die deze studie heeft geschreven weet zich door de industriële geschiedenis van de stad beïnvloed, al kent hij van de fabrieken alleen de buitenmuren goed.

We might [...] take a hint from the social anthropologists and scrutinize our industrial mythology as one of the clearest unconscious signals of underlying cultural attitudes" (Hannah, 1984: 227). Petrus Regout is een relatief onbekende in de Nederlandse industriële mythologie, die toch al weinig tot de verbeelding sprekende helden en schurken kent (vgl. Van Iterson \& Olie, 1992) ${ }^{14}$ Maar in Maastricht is zijn nagedachtenis levend.

13 De invloed van gebeurtenissen, zoals bijzondere daden van individuen, mag niet worden verwaarloosd. Evenementen zijn niet slechts, zoals sommige Franse geschiedkundigen zeggen, 'l'écume des jours', het schuim van de dagen.

14 Een citaat: 'In general, charismatic or heroic leadership is not a common phenomenon in the Netherland, nor is it something considered worth striving for. Biographies of Dulch captains of industry are more or less nom-existent [...]'. Zie ook: Franke \& Whitlau, 1979: 112. 
Bij velen leeft hij voort als schurk; bij een kleine groep als held ${ }^{15}$, maar niet als wat hij in de eerste plaats is geweest: de belangrijkste Nederlandse industrieel van de negentiende eeuw en zeker de belangrijkste economische actor in de geschiedenis van de stad. Hoewel ik het geloof in ontmythologiseren als belangrijkste taak van de sociale wetenschappen de meest antipathieke trek van hun beoefenaren vind, denk ik dat men deze entrepreneur beter begrijpt als men de morele schijnwerpers van hem wegdraait.

Het huis van de economische en sociale wetenschappen kent vele kamers. Steeds meer beoefenaren van die vakken vinden dat het huis erop vooruit gaat als hier en daar een tussenmuur wordt uitgebroken. Dit boek is geen strikt sociologische studie, al is de sociologie mijn achtergrond; noch een strikt historische studie, al betreft het de beginjaren van de Industriële Revolutie; noch een strikt economische studie, al werk ik nu aan een economische faculteit. Dit proefschrift beweegt zich, om opnieuw de economische historicus Leslie Hannah aan te halen, in 'the unoccupied territory bordered by economics, history, and sociology. Historische organisatie-economie en -sociologie kan het beste worden bedreven door historici, economen en sociologen tezamen.

Dit boek is voor een belangrijk deel de vrucht van uren tegenover het computerscherm. Deze uren waren gewijd aan, om de essayist K.L. Poll aan te halen, 'het vinden van de passende formule' (NRC-Handelsblad, 1212-1986). Misschien is 'het vinden van de passende formulering' correcter, maar dan is men de aardige vergelijking met de natuurwetenschappen kwijt. Hopelijk kan in deze formuleringen dienstbaarheid aan het centrale thema worden herkend. Ik heb anekdotiek zoveel mogelijk vermeden (al ging dat soms met een spijtig gevoel). Niettemin beweegt ook deze studie zich in het grote grijze gebied tussen kroniek en logica. Men moet oog hebben voor de contingentie, maar er niet mismoedig van worden. Men moet zoeken naar patronen en regelmatigheden zonder het echte leven te kort te doen. Het aspect van toeval sluit verklaringen niet uit; verklaringen moeten toeval kunnen tolereren.

In 1834 besluit Petrus Regout, die tot dat jaar in onder meer glas en kristal had gehandeld, zelf een fabrieksmatige slijperij ${ }^{16}$ te beginnen. Vier jaar later richt hij een eigen blazerij op. Twee belangrijke beslissingen in een

15 Merkwaardig genoeg was het De Volkstribune, het Socialistisch Weekblad woor de Zuidelike Provincim, van 12 oktober 1895, die sprak van den door de arbeiders geliefden en geprezen "oude Regout" (geciteerd in: Perry, 1983: 57).

16 Al vanaf $1826 / 27$ had Regout vier slijpers in dienst, maar zij werkten met niet-mechanisch aangedreven slipstoelen. 
reeks: in de jaren dertig en veertig begint Regout ook nog een spijkerfabriek (1834; samen met broer Thomas en zijn zwager J.G. Lambriex), een aardewerkfabriek (1836), een geweerfabriek (1842) en een gasfabriek (1847).

Het was een reeks van beslissingen om zelf fabrieksmatig te gaan verwerken en produceren, en wel op verschillende fronten, zoals Regout ook op verschillende fronten kocht en verkocht. In de economische aktiviteiten van Regout trad een doorslaggevende verschuiving op van produkten kopen naar produkten maken. In het organisatietheoretische jargon heet dat: van 'buy' naar 'make'. Een groot aantall transakties wordt niet meer via de markt (in dit geval de inkoopmarkt van goederen) afgesloten, maar in de zelf gecreëerde hiërarchie (Williamson, 1975). Kortweg: van 'markt" naar hiërarchie", ofwel: van markt naar plan, ofwel: van markt naar organisatie (het begrippenpaar waaraan o.a. Herbert A. Simon de voorkeur geeft, 1991: 21), ofwel: van Adam Smith's onzichtbare hand die de markttransakties regelt naar Alfred Chandler's zichtbare hand die de coördinatie birnen organisaties tot stand brengt (1977, i.h.b. pp. 1-12).

De verschuiving naar het hiërarchisch coördineren van economische beslissingen hield tevens in dat de inspanningen die moesten worden geleverd om ook menselijke aktiviteiten (geschoolde en ongeschoolde arbeid) te coördineren drastisch toenamen. De verschuiving betekende echter ook dat Regout's vraag op de arbeidsmarkt groeide. Daarom worden hier deels marktproblemen, deels organisatieproblemen beschreven en geclassificeerd.

Zoals in het volgende hoofdstuk zal worden beschreven, nam Regout zijn eerste 'make'-besluit onder bijzondere omstandigheden: tijdens de Belgische Opstand (1830-1839) was de vestingstad Maastricht een Nederlandse egelstelling en daarmee ook economisch geïsoleerd. Omdat in een geheim rescript van 1833 werd bepaald dat het in Noord-Nederland in te voeren glas en kristal uit Maastricht ter stede diende te worden geslepen (met de opzet een eind te maken aan doorvoer van eindprodukten uit de opstandige gebieden), was handel op het Noorden voor Regout nog slechts mogelijk als hij zelf ruw glas en kristal ging bewerken. Het is de

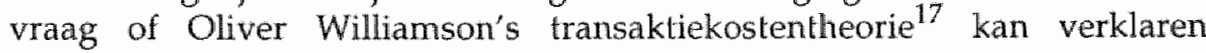

${ }^{17}$ In één zin: als de kosten van markttransakties (transaktiekosten) hoger zijn dan de kosten van afstemming binnen de eigen organisatie (coördinatiekosten), zal ervoor worden gekozen de aktiviteit binnen de organisatie te laten plaatsvinden - en vice versa. De belangrijkste transaktiekosten zijn kosten verbonden. aan het zoeken van een tegenpartij, aan het opstellen van contracten en kosten ter vermijding van contractbreuk. De belangrijkste coördinatiekosten zijn de extra loonkosten verbonden aan afstemming en kosten van vergaderruimtes, telefoongebruik, papier, enzovoort (Williamson, 1975, 1985; zie bijvoorbeeld ook: Douma 
waarom Regout in dit geval besloot de markt deels in te ruilen voor de bewuste onderlinge afstemming van de organisatie. Waren de (handelsipolitieke ontwikkelingen en bepalingen niet dermate belemmerend dat Regout als inkoper niet eens meer transaktiekosten kón maken? Dit incident mag aantonen dat institutionele gegevenheden en veranderingen zó dwingend kunnen zijn dat moeilijk nog kan worden gesproken van individuele keuzen tussen markt en organisaties op basis van afweging tussen transaktiekosten en coördinatiekosten. Terecht noemt de kunsthistoricus Aart Mekking Regout een 'industrieel-uit-noodzaak' (1975 : 11).

Bij andere fabrieken die Regout heeft opgericht, is het beter mogelijk aan te tonen dat ze zijn ontstaan in situaties dat de transaktiekosten hoger werden dan de coördinatiekosten: zie de beschrijving van de oprichting van de blazerij in hoofdstuk 2. Anders gezegd, in die gevallen is het gemakkelijker om te abstraheren van de meer specifieke demografisch-economische, politiek-bestuurlijke en sociaal-culturele omstandigheden waardoor de transaktiekosten van een en ander op bepaalde momenten in bepaalde plaatsen veranderden. Maar mijn argument is juist dat sociaalinstitutionele factoren ${ }^{18}$ - die soms worden beschouwd als een additionele produktiefactor - onvoldoende recht wordt gedaan als ervan wordt geabstraheerd. Het is steeds een uitdaging te beschrijven en verklaren hoe, bijvoorbeeld, een 'make-or-buy'-beslissing samenhangt met andere ${ }^{19}$ plaats- en tijdgebonden sociale en economische veranderingen.

Dat ook het begrip 'context' idealiter dynamisch wordt opgevat, hoeft amper betoog. De meest constante eigenschap van de 'werkelijkheid' is haar veranderlijkheid. Maar de allesoverheersende nadruk die door sommige sociologen op het veranderlijke karakter van sociale verschijnselen

\& Schreuder, 1991, h. 7).

18 Het is een klein satanisch genoegen te overwegen dat Williamson's theorie zelf, universeel en abstrakt als deze mag lijken, gekleurd is door de nationale cultuur waarvan de bedenker deel uitmaakt. De Amerikaanse econoom Williamson ziet het sociale leven als een verzameling economische transacties tussen individuren. In andere landen is deze visie veel minder vanzelfsprekend. Hofstede: "What is interesting about this theory from a cultural point of view is that the "warket" is the point of departure or base model, and the organization is explained from market failure' (1991: 149).

${ }^{19}$ De meeste beslissingen zijn sociale veranderingen. Veel beslissingen worden genomen door mensen en voor (of tegen) mensen, en betekent voor beide partijen een verandering. Zelfs een beslissing dat iets niet zal veranderen of een beslissing die nooit ten uitvoer wordt gebracht, brengt doorgaans consequenties met zich nee zowel voor de persoon of de groep die deze beslissing wilde nemen als voor degenen die ermee te maken zouden lrebben gekregen, en is derhalve een sociale verandering. 
wordt gelegd ${ }^{20}$, ontneemt hen vaak het zicht op belangrijke subtiliteiten. $^{21}$ Deze subtiliteiten, die soms verwijzen naar aspecten van grote reikwijdte, komen beter tot hun recht in een meer statische, interpretatieve beschrijving (vgl. de omschrijving van 'thick description' door de antropoloog Clifford Geertz, 1973: 3-3022) - net zoals sommige details alleen tot je doordringen als je de film stilzet of in slow motion afdraait.

In de literatuur over organisatiecultuur - een begrip dat in het afgelopen decennium tot veel en soms boeiend onderzoek heeft geinspireerd wordt meermalen gewezen op het gewicht van de oprichter(s) van een organisatie in deze. Niet alleen hebben zij de eerste, belangrijke stap gezet in het ontwikkelen van een organisatie-specifiek systeem van waarden en normen (bv. Schein, 1983), ze zijn ook voor latere leden vaak het voorbeeld van hoe het moet of soms hoe het niet moet (bv. Hofstede, die helden/anti-helden, naast symbolen en rituelen, rekent tot de belangrijkste cultuurelementen, 1991: 7-8). ${ }^{23}$ Het onderwerp van stijlen en legitimaties van industriële pioniers als onderdeel van de wording van organisatieculturen is echter nog nauwelijks ontgonnen. Het verkennende karakter van deze studie is eveneens een reden geweest om te kiezen voor een tamelijk statische beschrijving en ordening. ${ }^{24}$ Het hanteren van een onwikkelingsperspectief lijkt voor het moment te moeilijk. Daarom zal het woord 'patronen' vaker voorkomen dan het even lelijke 'processen'.

20 Wat naar voren komt in onder andere het hanteren van een vogelvluchtperspectief - een 'bird's eye view' dat vaak over eeuwen scheert.

21 En op wat slechts uiterst langzaam verandert ondat het tot routine is geworden.

Als men een forse stap achteruit doet, ziet men natuurlijk dat alles in beweging is - net zoals we op de lange termijn allemaal dood zijn. Maar voor het moment leven. we nog en gaan elke dag naar de fabriek of het kantoor, bijvoorbeeld. En als we daarvan te zeer op een afstand gaan staan zien we de - voor het fabrieksen kantoorleven zo belangrijke - routines niet.

22 Een mooi citaat: "It is not against a body of uninterpreted data, radically thinned descriptions, that we must measure the cogency of our explications, but against the power of the scientific imagination to bring us in touch with the lives of strangers. It is not worth it, as Thoreau said, to go round the world to count the cats in Zanzibar" (ibid., p. 16).

${ }^{23} \mathrm{Om}$ verwarring te voorkomen wil ik hier graag de waarschuwing van B.J. Loasby aanhalen: 'In the great majority of large firms the entrepreneur' does not exist. In his place there is an organization; and a organization is not a collective entreprenewr" (1967: 171).

$24 \mathrm{Zo} z a \mathrm{l}$ in het vierde, meest theoretische hoofdstuk een permanent evenwicht worden verondersteld tussen markt en hierarchie, met het fabriekssysteem als dominante organisatie van de industriële ondernemingen. Ook zal een onbeperkte toegankelijkheid tot deze nieuwe organisatievorm worden aangenomen. 
Eerder dan naar dynamisering van de context wordt hier gestreefd naar het winden van het juiste midden in de hoeveelheid context. De aspecten van werven, behouden en beheersen van arbeid in het vroege fabriekssysteem worden slechts tot op zekere hoogte gezien tegen hun institutionele achtergrond. Door er meer context bij te halen, kan men de "waarheid" omtrent, bijvoorbeeld, een beslissing wat "voller" maken. Maar de volledig 'volle waarheld' kan men niet bereiken. En dat niet alleen: aan de volledig volle waarheid zou men wetenschappelijk niet veel hebben. Een bedrijfseconomische beslissing in een meer specifieke sociale en institutionele context plaatsen levert winst op: verbreding van het perspectief, verdieping van kennis en begrip. Maar het houdt ook verlies in: de reikwijdte van een formulering wordt drastisch ingeperkt als men die formulering stelt in een idioom dat directer verwijst naar meer specifieke veranderingen.

In de meer algemene terminologie van een relatief beperkt perspectief krijgt men een beter antwoord op de vraag: waarom richt iemand een fabriek op? In de meer specifieke terminologie van een breder perspectief kan men een nauwkeuriger antwoord krijgen op de vraag: waarom richtte Petrus Regout in de jaren dertig en veertig van de vorige eeuw in Maastricht een glas- en kristalfabriek, een spijkerfabriek, een aardewerkfabriek, een geweerfabriek en een gasfabriek op?

"Was ist das Allgemeine?/Der einzelne Fall./Was ist das Besondere?/Millionen Fälle,' schreef Johann Wolfgang von Goethe in Wilhelm Meisters Wanderjahte.

Dit is dus de schijnbare paradox: een verklaring in meer algemene termen verwijst slechts naar een specifiek aspect van een verschijnsel. Wil men een groter aantal aspecten verklaard zien, dan moet men in meer concrete termen gaan spreken, dan moet er meer context bij worden betrokken. De meest vruchtbare taktiek is die van de tussenkoers, want als men te hoog op de "abstractieladder" (Hayakawa, 1972: 152-3) klimt, wordt te weinig van het bestudeerde verschijnsel verklaard. Men maakt zich dan schuldig aan découpage: '(..) het uit zijn verband rukken van verschijnselen die juist aan dit verband hun betekenis ontlenen' (Blok, 1982: 204): een deel van een bepaalde werkelijkheid isoleren (en in een andere context plaatsen), hetgeen een vervreemdend effect kan teweegbrengen, want 'd)ezelfde dingen kunnen in een verschillende context een verschillende betekenis hebben' (ibid.). Men kan ook zeggen: des te minder context, des te meer stereotypie. De mogelijkheden tot vergelijkingen nemen toe, maar wel ten koste van een zekere simplificering van het portret. Als deze simplificering drastische vormen aanneemt, dreigt het gevaar van stereotypie. Stereotypen - halfwaarheden, aldus Hofstede (1991: 253) - zijn verleidelijk: ze lijken gemakkelijker op elkaar en ze verschillen gemakkelijker van elkaar, omdat men slechts op een aantal kenmerken hoeft te letten. 
Klimt men daarentegen te ver de abstractieladder af - betrekt men er veel context bij - dan boet men te veel aan reikwijdte in en wordt systematische vergelijking moeilijk. Bovendien dreigt men dan in idiosyncratie en descriptie te verzanden. In de taktiek van de tussenkoers wil zoveel mogelijk recht worden gedaan aan de 'volle waarheid', maar in dusdanige bewoordingen dat men nog vergelijkingen kan trekken. Ook om bedrijfseconomische problemen te bestuderen lijkt het snijvlak van een breed perspectief met geringe reikwijdte en een beperkt perspectief met grote reikwijdte de vruchtbaarste uitgangspositie.

De onderzoekseenheid in deze studie wordt gevormd door Petrus Regout in zijn hoedanigheid van industriële entrepreneur uit de beginjaren van de Industriële Revolutie. Omdat in het derde en vierde hoofdstuk het perspectief wordt verbreed naar de gehele groep van industriële entrepreneurs in West-Europa tussen 1780 en 1870 , kan men ook zeggen dat zij mijn onderzoekseenheid vormen. Deze 'early factory masters', om de titel van S.D. Chapman's studie naar de textielfabrikanten in de Midlands aan te halen, kan men beschouwen als pioniers. Er bestaan pioniers in de ruimte (mensen die verder kwamen dan anderen, zoals frontier people, ontdekkingsreizigers en ruimtevaarders) en er bestaan pioniers in de tijd (mensen die eerder waren dan anderen, zoals uitvinders, kunstenaars, geleerden en ook industriëlen). Beide soorten pioniers zijn, in de letterlijke zin van het woord, marginalen. Zij moeten beslissingen nemen in situaties die zich niet eerder hebben voorgedaan, die minstens één stap verder gaan. Daarbij is de keuzevrijheid relatief groter, want er is nog geen praxis ontwikkeld van standaardoplossingen. Het is hier dat het begrip 'stijl' een belangrijke rol speelt.

Marginaliteit betekent vaak ook onzekerheid en onduidelijkheid, in de eerste plaats voor de marginalen zelf. Maar ook anderen, de belanghebbenden, is het niet (helemaal) duidelijk welke motieven hun keuze voor marginaliteit bepalen, hoe hun gedachten, daden en nieuw ontwikkelde praktijken kunnen worden geduid en waar deze pioniers in de bestaande statushiërarchie zijn te plaatsen (vgl. Stanworth \& Curran, 1973, over de sociale marginaliteit van entrepreneurs). Vanwege deze onduidelijkheid, die onzekerheid schept, is 'ambiguiteit' het tweede kernbegrip (na 'stijl') waarom het in de verklarende hoofdstukken zal draaien. Om onzekerheid en onduidelijkheid te reduceren zullen velen hun nieuwe marginale positie willen legitimeren. Dat kan men ook bij de industriële pioniers herkennen. Daarom is 'legitimatie' het derde kernbegrip.

Aangaande entrepreneurs (dus ook industriële pioniers) vroeg Joseph Schumpeter (1934) bijzondere aandacht voor hun bekwaamheden en wilskracht. Hij introduceerde het denkbeeld van nieuwe combinaties ('neue Kombinationen'). Entrepreneurs brengen verandering teweeg door be- 
staande evenwichten te vernietigen. Door andere produkten en technieken te introduceren, nieuwe markten open te leggen ${ }^{25}$, kunnen er grote winsten worden gemaakt. Deze nemen weer af als er zich navolgers aankondigen, wat de entrepreneur op zijn beurt weer aanspoort tot het zoeken naar nieuwe winstkansen. Aldus opererend vormen ondernemers een 'dynamische kracht' in de samenleving.

In het leggen van nieuwe combinaties kunnen ook vernieuwingen van organisatiestructuren een belangrijke rol spelen. Schumpeter: "The fundamental impulse that sets and keeps the capitalist engine in motion comes from the new consumers' goods, the new methods of production or transportation, the new markets, the new forms of industrial organization that capitalist enterprise creates' (1981: 83). En verderop: '[..] the organizational development from the craft shop and factory to such companies as U.S. Steel illustrate[s] the same process of industrial mutation - if I may use that biological term - that incessantly revolutionizes the economic structure from within, incessantly destroying the old one, incessantly creating a new one.'

Ook het structureren van organisaties speelt in het voortgalande proces van creatieve destructie een essentiele rol. In de jaren dertig stond het concept organisatiecultuur nog niet in de belangstelling. Maar het is geen gewaagde veronderstelling dat Schumpeter ook nieuwe organisatieculturen (gevormd door de stijl van de pionier of het resultaat van een latere culturele revolutie of, in jargon, "tumaround') had beschouwd als mogelijk element van een nieuwe vruchtbare combinatie. Hetzelfde geldt voor nieuwe vormen van werving, behoud en beheersing van arbeid.

Met het erkennen van het doorslaggevende belang van moeilijk grijpbare kwaliteiten als bekwaamheid, wilskracht en creativiteit stuiten we op een ander methodologisch probleem: modelleerbaarheid van menselijk gedrag. Leslie Hannah: 'It may be that in many fields we cannot progress to greater theoretical precision, for the analysis of change - and that is at the heart of the entrepreneurial function - is the most difficult problem the social sciences face. The logical consequence of granting entrepreneurs the creative role in transforming production and consumption functions [.] is, in fact, to reduce the determinacy of their actions, and hence to increase the difficulty of rnodelling them in a way that captures their essence

25 Het lijkt erop dat grote beslissingen, zoals de evenwichtsvernietigende nieuwe combinaties, minder gemakkelijk uit hun context kunnen worden gehaald dan kleinere, meer routinematige beslissingen (die zich eenvoudiger in een abstract idioom laten beschrijven en verklaren). Anders gezegd: Schumpeter's 'entrepreneurial function' ('making strategically important or innovating decisions') verdient meer plaats- en tijdgebonden verklaring dan diens 'managerial funcfion' ('maintaining the more routine operations of a business organizations')(Ibid.). 
Onderkenning van het creatieve element in het vinden van oplossingen voor bedrijfsproblemen maakt de vraag 'waarom is voor deze oplossing gekozen en niet voor andere?" moeilijker te beantwoorden. Maar hier wordt alleen naar externe waaroms gekeken: mogelijkheden en beperkingen voortwloeiend uit markten, instituties, techniek en de factor arbeid zelf. De psychologie van de entrepreneurs blijft bijna helemaal buiten beschouwing.

Daarmee wil niet gezegd zijn dat beslissingen van individuen slechts een minimale rol worden toegekend. Opnieuw moet hier stelling worden genomen tegen de sociale wetenschappers die een sterke nadruk leggen op verandering - of preciezer: op de structuur van veranderingen - zoals de figuratiesociologen die zich door het werk van Norbert Elias laten inspireren. Evenals de populatie-ecologen in de Amerikaanse organisatietheorie, met Michael T. Hannan en John Freeman als grondleggers, neigen zij ernaar slechts oog te hebben voor het blinde karakter van processen, de onbedoelde gevolgen waar individuen nauwelijks greep op hebben. Dit gezichtspunt staat haaks op het (in de economie nog steeds belangrijke) concept van de homo economicus - een individu dat na (perfect dan wel gelimiteerd) rationele afweging to individuele beslissingen komt. In extremo zijn beide gezichtspunten werkelijkheidsvreemd. Het is niet alleen uit romantische overwegingen dat het belang van creativiteit, persoonlijkheid en stijl hier wordt onderstreept. Wat ook meespeelt is het vermoeden dat economen en sociologen worden afgeschrokken door de donkerte van dit gebied en daarom afzien wan beschrijving, ordening en modellering.

Ook hier lijkt het bewandelen van een tussenweg de meest belovende route. Men moet oog hebben voor de (suprarationele) entrepreneuriële bekwaamheden en talenten zonder echter uit het oog te verliezen dat bekwamen en getalenteerden het geluk moeten hebben 'de omstandigheden' mee te hebben. Bijvoorbeeld: een ontluikende markt voor massaconsumptie-artikelen, zoals koffie en thee, die weer de vraag naar goedkoop aardewerken serviesgoed deed stijgen. Of: subsidies van de overheid en/of kredieten van een financiële instelling. Of: een forse erfenis die kan worden aangewend als startkapitaal. Zonder marktgeluk, institutioneel geluk of particulier geluk kunnen zelfs de meest creatieven geen vruchten wan hun gaven plukken. It take's two to win: talenten en kansen, zoals ook een artikel van de organisatiedeskundige John Langton over Josiah Wedgwood en de Britse aardewerkindustrie duidelijk heeft gemaakt (1984). Leslie Hanmah (1984) merkt terecht op dat entrepreneurs niet simpelweg optimaliserende actoren zijn binnen de onwrikbase grenzen wan bepaalde beperkingen, maar mensen met de potentie om deze beperkinger te overwinnen of veranderen door nieuwe technieken of organisaties te ontwikkelen of door nieuwe industrieenn te betreden (1984). 
Niettemin wordt deze potentie ingeperkt door beperkingen van de markt, de omgeving ${ }^{26}$ en de eigen fysieke persoon. ${ }^{27}$

Deze opmerkingen leiden tot de probleemstelling van deze studie:

in hoevere waren patronen van weroen, behouden en beheersen wan arbeid door industrielle entrepreneurs in de begintijd van de Westeuropese Industrielle Revolutie - in het bijzonder Petrus Regout - een resultante van i) de markt-en ongeringsfactoren (en de eigen fysieke beperkingen) en ii) hun persoonlijke stijl wan denken, zoelen en handelen?

In het vijfde hooldstuk zal een poging worden ondernomen een antwoord op deze vraag te formuleren, nadat in het derde en vierde hoofdstuk respectievelijk de sociaal-economische historische context van de opkomst van het moderne fabriekssysteem in West-Europa is geschetst en een organisatie-theoretische analyse van problemen van werving, behoud en beheersing van arbeid is gegeven. Daarvóor in het volgende hoofdstuk, moet echter een (globale) beschrijving worden gegeven van het 'geval' dat me tot de probleemstelling heeft gebracht: de geschiedenis van de glas-, kristal- en aardewerkfabrieken van Petrus Regout in de periode van 1834 tot 1870 .

26 Daarbij moet echter wel aangetekend dat in de beginjaren de entrepreneurs nog nauwelijks lijn- en stafmanagers hadden, met wier mening enigermate rekening alliende te worden gehouden. (Pas toen de bedrijven te groot werden om door één individu te worden beheerst, werden meesterknechten en andere geschoolde arbeiders gerecruteerd on dergelijke functies te gaan bekleden). Ook de arbeiders- en vakbeweging stond in de eerste decennia nog in haar kinderschoenen. Overheidsbemoeienissen en invloed van de publieke opinie waren beide geringer dan in latere jaren. Het aantal en het gewicht van belanghebbenden was eveneens klein. De belangrijkste partij die invloed uitoefende was vaak de vrouw of de risicodragende familieleden van de entrepreneur. Al met al lijkt de "managerial discretion' - een belangrijke factor bij de bepaling van de aard van het bedrijf (Whitley, 1991) - voor de Westeuropese fabrikanten in de formatieve jaren van de industrialisering hoog.

27 Men moet her denken aan het simpele feit dat een individu slechts over een bepaalde mate van (arbeids)energie beschikt, dat hij maar op éen plaats tegelijk kam zijn, dat hij kan worden getroffen door ziekte, enz. 


\section{HOOFDSTUK 2}

\section{HET GEVAL: DE GESCHIEDENIS VAN DE GLAS-, KRISTAL- EN AARDEWERKFABRIEKEN VAN PETRUS REGOUT}

Petrus Laurentius Regout liet de wereld heel wat na, toen hij in 1878 op zijn landgoed Vaeshartelt overleed. Een fabrieksimperium, om te beginnen, dat een 70 gebouwen bevatte en 9,8 ha van de binnenstad van Maastricht besloeg en waar 2573 arbeiders werkten. Daamaast een vermogen van bijna drie miljoen gulden, waarvan ongeveer 2,5 miljoen in zijn ondernemingen was geinvesteerd. Petrus Regout heeft ook een naam nagelaten of meerdere namen: gunstige en ongunstige. Hij wordt geroemd als eerste 'grootindustrieel' van Nederland, die zijn tijd, een Jan Salietijd, ver vooruit was, een man met een opmerkelijk talent voor ondernemen, aldus Joel Mokyr (1976: 121-4). Maar Petrus Regout wordt tevens verguisd als uitbuiter - al moet gezegd dat velen hem verwarren met zijn oudste zoon, pretendent en naamgenoot.

Petrus Regoul, geboren in 1801 in de Maastrichtse Nieuwstraat, stamt uit een familie van kooplieden, die in de tweede helft van de zeventiende eeuw van Luik naar Maastricht verhuisde. ${ }^{1}$ Zijn ouders dreven een grooten kleinhandel in Engels aardewerk en Frans kristal en porselein. Omdat zijn vader vroegtijdig kwam te overlijden, werd Petrus op dertienjarige leeftijd van school genomen om in de zaak mee te helpen. Op zijn achttiende ging hij zich toeleggen op de import en groothandel. ${ }^{2}$ Zijn werk-

${ }^{1}$ Tenzij anders aangegeven zijn deze gegevens afkomstig uit Maenen's proefschrift, Petrus Regowt 1801 - 1878, Nijmegen, 1959, i.h.b. hoofdstuk 2 en 3. Over de familie Regout wordt in het Economisch Archief van Nederland en Koloniën geschreven: [..] une famille ou la fabrication et le commerce du verre et de la faïence étaient une tradition et qui s'implanta à Maestricht dans la seconde moitié du 17ème siècle, venant du pays de Liège, où déjà elle avait importé de Venise la fabrication des verres si réputés' (1936: 3-4). Deze familie van handelaren behoorde bepaald niet tot het Bildungsbïrgertum. In dat opzicht verschilde Petrus Regout zeer van Josiah Wedgwood, die zich bewoog in kringen van liberal reformers - men who read and gave him to read the works of Priestley, Price, Paine, Rousseau, Cartwright, Howard and Malthus. From these he formed his decided views of society' (McKendrick, 1966: 77).

${ }^{2}$ Zijn moeder en zijn twee broers concentreerden zich op de detailhandelsaktiviteiten van de handelszaak 'De Weduwe P. Regout en Zoonen'. 
terrein lag voornamelijk in de Zuidelijke Nederlanden ${ }^{3}$, in het bijzonder in het (voorheen daarvan onafhankelijke) Luikse, waar, evenals in Henegouwen, het moderne fabriekssysteem al zijn intrede had gedaan. ${ }^{5}$ De belangrijkste lange-termijnrelaties bouwde hij op met de Cristallerie de Vonêche (in de huidige provincie Namen) die in 1803 was gesticht door de Fransman Aimé Gabriel d'Artigues, die al spoedig de leidende glasfabrikant in het Franse Keizerrijk werd (Chambon, 1955: 285) en met de in een ontruimde Cisterciënzer abdij bij Seraing, in de buurt van Luik, gehuisveste Verreries et Cristalleries du Val St.Lambert, in 1826 opgericht door twee medewerkers van d'Artigues, F. Kemlin en A. Lelièvre, respectievelijk administrateur en onderdirecteur (Lebrun et al., 1981). De Val St.Lambert groeide in de jaren dertig uit tot de grootste glas-en kristalfabriek van België (zie ook: Mokyr, 1976: 77).

Nadat Petrus in 1825 was getrouwd met Maria Aldegonda Hoeberechts (1798-1878), uit een familie van hoedenmakers, betrok het echtpaar in 1827 een huis aan de Boschstraat, dat door Regout's moeder was gekocht (nr. 1303), vanwaaruit het fabriekscomplex werd opgebouwd dat een behoorlijke vlaaipunt van de binnenstad zou gaan beslaan. In deze allesbehalve krappe woning ${ }^{6}$ kregen zij vier dochters en zes zonen - Petrus, Eduard, Eugène, Louis, Victor en Gustaaf, die allen (behalve de op tweejarige leeftijd overleden Victor) aan de fabrieken van hun vader zouden worden verbonden. In een gedeelte van dit pand, dat tegenover het Bassin, de nieuwe havenkom van het kanaal naar Den Bosch, lag, vestigde Regout zijn handslijperij van glas en kristal. In deze slijperij werkten vier vaklieden - drie Zuid-Nederlanders en één buitenlander - die het vak hoogstwaarschijnlijk in de Cristallerie de Vonêche hadden geleerd en die - even-

3 Conform het besluit van het Congres van Wenen werd het huidige Belgie in 1815 bij de Noordelijke Nederlanden gevoegd, die samen het Koninkrijk der Nederlanden gingen vormen onder Koning Willem 1.

In Luik opende Petrus een magazijn.

5 Hierbij moet aangetekend dat de Zuidnederlandse industrie na de Franse tijd werd geplaagd door een terugslag, die tot eind jaren twintig van de negentiende euw duurde.

${ }^{6}$ In de Joumat de la prozmce de Limbourg van 10 februari 1827 wordt het pand te koop aangeboden met deze kwalificaties: 'cette maison est solidement bâtie, à la moderne; elle a de nombreux appartements, porte-cochère, écuries, grandes caves, jardin etc. etc' en: '(..) elle conviendrait fort bien pour y établir un hôtel, maison de commission ou quelqu'autre branche de commerce (..)" (geciteerd in Regout, 1959: 17). 
eens hoogstwaarschijnlijk - bij de Regouts in huis woonden. ${ }^{7}$

Voor Regout waren deze nijverheidsaktiviteiten volledig ondergeschikt aan zijn handelsaktiviteiten. Dat veranderde drastisch, zoals in het vorige hoofdstuk al is aangestipt, toen in 1830 in Brussel de Belgische Opstand uitbrak, die het begin was van de afscheiding van de zuidelijke provincies. In een brief uit 1834 aan Buitengewoon Commissaris ${ }^{8}$ Gericke van Herwijnen schrijft Regout, die toen al 33 was, over zijn reden om zelf fabrieks matig glas te gaan slijpen: "[I]k heb moeten besluiten eene slijperij met beduidende opoffering alhierop te rigten, wilde ik mijne glashandel (door mijne voorouders en mij gedreven) niet zien te niet gaan' (geciteerd in Maenen, 1959: 185).

Door de rebellie van de zuidelijken ondervond Regout's handel ernstige moeilijkheden. Niet alleen werd de stad Maastricht enkele maanden belegerd - vanaf september 1830 mocht niemand de vesting in of uit zonder een speciale pas - ook werden produkten uit Maastricht afkomstig in Noord-Nederland voor Belgische aangezien en opgehouden. Het gebrek aan transportwegen (de routes over opstandig gebied waren afgesloten) en de hoge in- en uitvoerrechten die zowel Zuid- als Noord-Nederlanders hieven, deden Regout's afzet eveneens drastisch dalen. De in- en uitvoerrechten werden bij geheim rescript in 1833 en bij Koninklijk Besluit in 1834 weliswaar opgeheven, maar het eerste besluit bevatte een belangrijke bepaling: het in Noord-Nederland in te voeren glas en kristal wit Maastricht diende ter stede te worden geslepen. Maenen: 'De handel in glas en kristal op Noord-Nederland was voor Regout dus nog maar alleen mogelijk voor zover het zelf geslepen produkten betrof. Wilde hij die handel echter doen floreren, dan moest het nadeel van de assortimentsbeperking (de Val St.-Lambert had in deze een flinke voorsprong, avi) genivelleerd worden. Petrus heeft dit in prijsverlaging van de geslepen artikelen gezocht, een verlaging, die alleen dán verkregen kon worden indien hij op grote schaal en machinaal ging slijpen' (ibid., p. 185). Bij John Cockerill in Seraing kocht Regout een stoommachine van acht pk, die op 31 januari 1835 in werking werd gesteld, niet alleen ten behoeve van de slijperij, maar ook voor zijn pas opgerichte spijkerfabriek. De machine kwam te staan in een nieuw opgericht gebouw, achter zijn woonhuis, waar hij ook nagenoeg alle 37 slijpers, die hij in dat eerste jaar had aangenomen, huis-

7 In het Bevolkingsregister van 1828 van Maastricht staan de volgende slipers vermeld: Johan Mausen, geboren in Tienen; Joseph Masson, geboren in Visé; Jaques Raphin, geboren in Montblanc (Spanje) en Henri Dubois, geboren in Her. dinnen. Volgens het Gedenkboek 125 N.V. Sphinx-Céramique 100 hebben zij misschien ook al bij Regout in zijn vorige woonhuis in de Jodenstrat gewoond, waar hij wellicht zijn slijperij is begonnen.

${ }^{8}$ Deze functie werd in 1841 ongezet in die van Gouverneur van het Hertog* dom Limburg. 
vestte (Regout, 1959: 25). Dit gebouw werd door een belastinginspecteur in 1834 omschreven als 'collossaal'. Om een idee van deze kolossaliteit te geven: in zijn woonhuis bevonden zich acht slijpstoelen, in het nieuwe gebouw was plaats voor tachtig.

Regout's beslissing om zelf fabrieksmatig te gaan slijpen wekte wrevel bij directeur F. Kemlin van de Val St.-Lambert. Toen Regout geen gehoor gaf aan het verzoek deze aktiviteiten te staken, zegde Kemlin de samenwerking op. Regout zocht contact met een nieuwe leverancier, de firma $L$. Zoude \& Cie in Namen, die een tweede glasoven installeerde. De overname van deze firma in 1838 door de S.A. des Manufactures de Glaces, die daarmee de hele Belgische glasnijverheid ging beheersen en de Nederlandse concurrentie graag geëlimineerd zag, betekende het einde van het contract. Daarop richtte Regout een eigen kristal- en glasblazerij op. Ook hier kostte het Regout 'aanmerkelijk groote opofferingen' om Franse en Zuidnederlandse geschoolde arbeiders naar Maastricht te lokken. Hij moest alle hunnen reiskosten, en vrij vervoer van huisboedel [..] betalen, buitendien de zeer sterke verhoging van arbeidsloon en hunne wrije woning en geneesheer, ingeval van ongesteldheid" (geciteerd in Maenen, 1959: 200-1). Hen moest 'une meilleure position' en 'un meilleur avenir' dan in hun eigen land worden gegarandeerd (ibid., p. 200). Mede dankzij de builtenlandse vakkennis - mogelijk heeft d'Artigues zelf bij Regout de technische leiding van de glastabriek in handen gehad - werden al spoedig produkten van goede kwaliteit vervaardigd.

Eerder, in 1836, was Regout een aardewerkfabriek begonnen. Wat voor de invoer in Noord-Nederland van glas en kristal uit Maastricht gold, gold ook voor aardewerk. Maenen: 'Ongetwijfeld heeft ook hier de wens om de handel te redden er toe geleid, dat Regout een aardewerkfabriek stichtte' (1959: 216). Tegen die tijd was het probleem van het initieel kapitaal - voor de aanschaf van een aardewerkoven, bijwoorbeeld - al niet meer zo nijpend: bovenop wellicht reeds gemaakte en niet-gereinvesteerde winsten en bovenop de bruidsschat van zijn vrouw ontving hij in 1835 bij het overlijden van zijn moeder een erfdeel van ruim 35.000 gulden. Daardoor was zijn beginkapitaal gestegen tot 45.000 gulden. Ook in deze fabriek moest Regout beginnen met geschoolde arbeiders van buiten de stad, van wie de meesten afkomstig uit het Naamse Andenne, een vindplaats van grondstoffen voor de zogenaamde Belgische fayence, ofwel volksaardewerk - al acht Maenen het niet ondenkbaar dat ook enkele Maastrichtse vaklieden van een fabriekje in Wyck naar Regout zijn overgestapt. ${ }^{9}$ De belangrijkste problemen bij de produktie van deze goederen

9 Met betrekking tot de aardewerkindustrie staat in het Gedenkboek 125 N.V. Sphinx-Cérnmique 100 vermeld: "Ook hiervoor trok hij vreemde werklieden uit België, Luxemburg, Frankrijk en Duitsland aan. Het is echter niet uitgesloten, dat 
waren technisch van aard: de kwaliteit van het succesvolle Wedgwoodaardewerk kon bij lange niet worden geevenaard; dat lukte pas halverwege de jaren vijftig, met behulp van Engelse vakkennis, methoden en kapitaallgoederen.

In 1842 volgden nog een geweerfabriek (waar op bestelling van het Rijk vuursteengeweren tot repercussiegeweren werden omgebouwd door uit de Luikse wapenindustrie weggelokte vaklieden) en in 1847 een gasfabriek (aanvankelijk slechts bedoeld als eigen toeleveringsbedrijf). De glas-, kristal- en aardewerkfabrieken ${ }^{10}$ zijn echter het meest succesvol gebleken. Van cruciaal belang in de geschiedenis van Petrus Regout's industriële initiatieven waren de late jaren veertig. Toen in 1847 en 1848 - het jaar van politieke woelingen in verschillende Europese landen (maar niet in Nederland) - een internationale economische crisis ook Regout's afzet deed stagneren, gokte hij erop dat de recessie, net als in 1843, van korte duur zou zijn. In het voorjaar van ' 48 kwamen de bestellingen vrijwel helemaal stil te liggen. Regout ontsloeg 136 werklieden, maar liet de overige 461 voor halve dagen doorproduceren, zodat zijn magazijnen volraakten. De legende wil dat ook de losplaats aan het Bassin en zelfs zijn woonhuis werden overwoekerd met manden vol glas en aardewerk. Maar Regout had goed gegokt. Toen het getij eind 1849 keerde, kon hij zijn voorraden vlot tegen profijtelijke prijzen verkopen. Hij had 'de slag van zijn leven' geslagen. Of deze kwalificatie terecht is, zou een gedegen analyse moeten uitmaken. De jaren vijftig lieten in ieder geval een opmerkelijke groei zien: op 1 april 1853 besloeg de personeelsomvang al 1046 personen en waren elf stoommachines in bedrijf, met een totaal vermogen van zo'n $130 \mathrm{pk}$. Op de Lijsten van de hoogst-aangeslagenen in de Provincie Limburg in 's Rijks directe belastingen steeg Regout van de elfde plaats in 1853 naar de derde in 1854. In die jaren ook kocht hij het landgoed Vaeshartelt in de gemeente Meerssen aan en wist hij door verwerving van panden zijn fabrieksterrein uit te breiden tot ruim 2 ha. Ook liet hij door gerenommeerde architecten een aantal woonhuizen aan de Boschstraat (ver)bouwen, onder meer om zijn erfgenamen in te huisvesten. Om de hoek, in de St.-Anthoniusstraat, in de stadswijk waar een groot deel van zijn arbeiders woonde, liet Regout een cité ouvrière bouwen. Geen arbeidersstad of woningencomplex, wat de naam doet vermoeden, maar een

naast die vreemde ook Maastrichtse vaklieden zijn te werk gesteld, werklieden, die in de in 1825 en 1829 te Maastricht bestaan hebbende porceleinfabrieken gewerkt hadden. De eerste lag aan de Rechtstraat, de tweede aan de Hogebrugstraat in Wijk' (Regout, 1959: 26). Die tweede fabriek moet de fabriek van Marchal zijn geweest, die volgens een melding uit 1828 elf werklieder telde.

10 En de daarmee samenhangende secundaire fabriekjes, zoals een zandwasserij, een potasfabriek, een kroezenfabriek, een meniefabriekje en een kalkbrande rij. 
woonkazerne van zeven verdiepingen, die aan 70 arbeidersgezinnen (circa 350 personen) onderdak bood. In de rechterzijvleugel van het gebouw bevonden zich halwerwege de verdiepingen insteekkamers, waarvan er éen dienst deed als lijkenhuis, zodat de bewoners niet langer een aantal dagen met cen overledene op de kamer hoefden door te brengen. Deze cité, in Maastricht 'de groete bốw' (grote bouw) genoemd, schreef Petrus Regout in een brief aan de gemeenteraad een 'Phillantropische bestemming' toe (Archief Petrus Regout, Contractenboek 26, p. 122-4), maar het gebouw zou later, in 1917, door hoofdaalmoezenier Henri Poels, de katholieke vakbondsvoorman, in een beroemde rede worden vervloekt als het in Nederland wellicht nergens zijn weerga vindend menschenpakhuis in de St. Anthoniusstratat (...) (Poels, z.j.: 111). Opmerkelijk is in elk geval de gevel van de Cité Ouvrière. De Duitse architect Wilhelm Wickop gaf er, geinspireerd door de neo-gotische mode van die tijd, een opvallende geleding aan. De kunsthistoricus Aart Mekking zag er een middeleeuwse stad in verkort perspectief in en meent dat deze suggestie met opzet gewekt. De middeleeuwse stad zou de bescherming en geborgenheid van een christelijke werkgemeenschap symboliseren.

In het vette derde kwart van de eeuw - waarin glazen en aardewerken gebruiksvoorwerpen steeds méér eettafels versierden - ging Petrus Regout zich van lieverlede minder bezighouden met de interne organisatie van zijn ondernemingen. ${ }^{11}$ Dat liet hij meer en meer over aan zijn zoons, zijn experts, zijn voormannen, zijn meesterknechten. Als jonge koopman reisde hij veel en dat deed hij nog steeds: beurzen, tentoonstellingen en potentiële alnemers waren zijn belangrijkste bestemmingen. Behalve in het (buiten)land verbleef hij ook steeds vaker op zijn buitenverblijf, dat hij een aristocratisch allure probeerde te geven met allegorische wandschilderingen en gevelversieringen, fonteinen en watervallen in het park en een herdenkingsmonument voor Koning Willem II. Eveneens legendarische proporties heeft de viering van het vijftigjarig huwelijksfeest van het echtpaar Regout aangenomen: al zijn arbeiders zouden zijn uitgenodigd op het 'bal Champêtre', dat tot diep in de nacht duurde. In een optocht van verschillende afdelingen - elk achter een zelfvervaardigd kunstwerk - trok men naar het landgoed: 'Zingende bereikte de massa Vaeshartelt, waar zij voor de terrassen in eerbiedige adoratie voor den industriekoning knielde', aldus het socialistische provinciale-statenlid Geel Ubachs in zijn in 1934 verschenen geromantiseerde aanklacht Een eeuw modern kapitalisme. De Regouts. Leed en strijd van Maastricht's proletariaat (Ubachs, 1976: 51-3).

11 Gedurende de eerste decennia van zijn industriële loopbaan nam zijn wrouw Aldegonda al een belangrijk deel van dit werk voor haar rekening. Zij was verantwoordelijk voor de financiële administratie, beheerde de kas en betaalde de lonen en de ziekenkasuitkeringen uit (Maenen, 1959: 86). De opvoeding wan haar negen kinderen zal ze gedeeltelijk hebben uitbesteed. 
Naast zijn ondernemerschap heeft Regout verschillende publieke functies vervuld en mengde hij zich volop in handelspolitieke en maatschappelijke kwesties. Van 1841 tot 1847 was hij lid van de Commissie van Contrôle van de Aken-Maastrichtse Spoorwegmaatschappij, van 1844 tot 1852 lid van de Kamer van Koophandel voor Maastricht, van 1849 tot 1859 lid van de Eerste Kamer van de Staten-Generaal, van 1851 tot 1853 lid wan de Maastrichtse gemeenteraad en van 1861 tot 1865 president van de (mede door hem opgerichte) Vereniging van en voor Nederlandsche Industriëlen. Zijn standpunt in diverse kwesties bracht hij naar voren in raad en kamer, maar legde hij ook neer in tientallen rekesten, open brieven en brochures, waarin hij niet aflatend het belang van de industrie voor de stad, de provincie en het koninkrijk verdedigde. De kwesties varieerden van het probleem van de aftappingen van Maaswater door de Belgen tot de controverse tussen de voorstanders van vrijhandel en de voorstanders van protectionisme (tot welke laatste groep ook Regout behoorde, die meende dat vrijhandel alleen wenselijk zou zijn als alle landen hun beschermingsmaatregelen lieten varen - een mening die hem zijn kamerzetel kostte). Het betrof lokale onenigheden, bijvoorbeeld over een door Regout aangevraagde concessie in Maastricht glazen gasbuizen te leggen, maar ook nationale discussies als het vraagstuk van het pauperisme of de kinderarbeid. Overigens zag men deze nationale ideologische tegenstellingen weerspiegeld in de persoonlijke ruzies op stedelijk niveau: Regout's tegenstrever, burgemeester W.H. Pijls, bediende zich van liberale retoriek, Regout zelf van een (katholiek-)conservatief idioom. Beide partijen hadden daarvoor hun eigen medium: Le Courrier de la Meuse was de spreekbuis van de Pylsiens, l'Ami du Limbourg die van Regout en de zijnen. De eerste was vurig Thorbeckiaans; de tweede even vurig antiThorbeckiaans.

Vanaf het begin van zijn industriële carrière stond Petrus Regout bekend als overtuigd orangist en pausgezinde ${ }^{12}$ - wat niet helemaal voor de hand lag in een stad waar onder de elites sympathie bestond voor de Belgische Opstand en een anti-clericale gezindheid niet vreemd was. ${ }^{13}$

${ }^{12}$ Een opvallende combinatie, want bij ultramontanen - hevige pausgezinden ging hun affectie voor de geest en opvattingen van Rome (dat ultramontanus lag: aan gene zijde van de bergen) ten koste wan hun eigen vaderland. Bedenk ook dat de Nederlandse monarch protestant was.

13 Maenen: 'De verbondenheid van het negentiende eeuwse Maastricht met België demonstreerde zich ook weer in het Maastrichtse liberalisme, dat als het ware een liberalisme van Belgische huize was: het anti-clericalisme viel hierbij als haar meest kenmerkende eigenschap op' (1959: 88). Dit anti-clericalisme was overigens niet alleen een vrucht van de Franse Verlichting, maar werd eerder al in de hand gewerkt door de cultuurpolitiek wan de Oostenrijkers, die institutionele hervormingsplannen voor Zuidelijke Nederlanden zagen gedwarsboomd 
Met hoge geestelijken, zoals aartsbisschop mgr. F. Graaf de Mérode, en met leden van het koningshuis onderhield Regout persoonljjke banden. Koning Willem I - die de industrie méér dan goedgezind was - verleende hem een krediet bij oprichting van zijn blazerij. waarop Regout uit dankbaarheid de eerste produkten van die blazerij aan de koning schonk, waarop Willem I weer een aantal grote orders plaatste. Regout's relatie met koning Willem II kwalificeert Maenen als 'welhaast vriendschappelijk" (1959: 111). Bij zijn bezoek in 1841 aan Maastricht - waar hij ook de glasen aardewerkfabrieken bezocht - werd hij begeleid door een erewacht van burgers, waarvan Regout een wan de commandanten was. Had ik maar een dozijn van zulke buitengewone mannen in het land, dan zou de voor ons verloren gegane Belgische industrie hier gemakkelijk weer worden teruggewonnen, moet Willem II over Regout hebben gezegd (aldus Petrus' zoon Gustaaf Regout, 1919). Het staat in ieder geval vast dat de koning het peterschap aanvaardde van het kind dat Aldegonda Regout toen in 1841 verwachtte, nadat hij Regout zelf al had geridderd. Ook plaatste hij, net als zijn vader, aanzienlijke orders bij Regout, waaronder twee paar kristallen kandelabers van in totaal 24.000 gulden.

Behalve tot ridder in de orde van de Nederlandse Leeuw werd Petrus Regout benoemd tot ridder van het (Franse) Légion d'Honneur en commandeur van het Heilig Graf, om de belangrijkste te noemen. Maar de begeerde verheffing in de adelstand bleef achterwege. Dit was waarschijnlijk des te teleurstellender omdat Belgische en met name Akense industriëlen, met wie Regout contacten had sinds de plannen voor een spoorlijn tussen beide steden, deze vorm van erkenning vaak well werd vergund (Mekking, 1975: 21). Eveneens moeilijk verteerbaar moet zijn geweest dat Regout nooit is geaccepteerd door de gevestigde elites van Maastricht en Limburg. "Hij (Petrus Regout, avi) leefde als een burger-edelman, maar werd door de oude elites als parvenu beschouwd,' meent de antropoloog Dick van den Bosch, die Regout 'de meest opmerkelijke nouveau riche uit de negentiende eeuw' noent (1979: 345).

Na 1870 begint Petrus Regout zich terug te trekken uit zijn ondernemingen. In zijn laatste jaren schijnt een zekere sentimentele megalomanie van hem bezit te hebben genomen, die zich uitte in praalzucht en lichtgeraaktheid. Typerend is het ambod dat Regout in 1872 aan Pius IX deed. Mocht deze uit het Vaticaan moeten wijken dan stond niet alleen kasteel Vaeshartelt tot zijn beschikking, maar ook Regout's hele fortuin: 'car c'est aux Bénédictions célestes que je dois mes biens temporels' (geciteerd in Maenen, 1959: 94). Toen Petrus Regout in 1878 stierf vermoedde hij zeer waarschijnlijk niet dat hij zou uitgroeien tot de meest controversiële persoon in de geschiedenis van Maastricht.

door kerkelijke tegenstand (De Vroede, 1981: 12-3). 
Het zijn de arbeidsverhoudingen in de fabrieken van Petrus Regout en zijn opvolgers - die de gemoederen omtrent deze fabrikant en zijn familie het meest in beroering houden. Het beeld dat in Maastricht 'toestanden werden aangetroffen, die veel geleken op de beruchte Engelse" (Brugmans, 1975: 105) is wijdverbreid.

Hoewel het garnizoen en de verdedigingswerken aan velen werk bood, kende Maastricht, door de gestage neergang van nijverheidsaktiviteiten zoals de leerlooierij en lakenweverij, een groot arbeiderspotentieel. In het begin van de negentiende eeuw was het aantal bedeelden in Maastricht groot. Uit een landelijk onderzoek naar de omvang van de armoede in het Koninkrijk der Nederlanden (toen nog inclusief het latere België) bleken Maastricht en Amsterdam de uitschieters naar de ongunstige kant: in beide steden leefde één op de drie inwoners van de bedeling. Ter vergelijking: in het Koninkrijk als geheel was de verhouding 1:9. Luik scoorde ook relatief ongunstig, maar was nog altijd twee keer zo gunstig als Maastricht: 1:6 (Regout, 1959: 104-5). Van de Maastrichtse bedeelden kwam veertig procent uit de Matthiasparochie (het Boschstraatkwartier) en vijfentwintig procent uit de St. Nicolaasparochie (het Stokstraatkwartier) (ibid., 106): de buurten waar later de meeste arbeiders van de fabrieken van Regout woonden. Het percentage bedeelden in Maastricht bleef ook in de jaren twintig en dertig van de negentiende eeuw uitzonderlijk hoog. Zo werd in de winter van 1830/31 32 procent van de bevolking ondersteund. En in 1841 bevond zich het aandeel bedeelden nog steeds in de buurt van één-derde van de bevolking (ibid., 105). ${ }^{14}$

De historicus Jos Perry spreekt van '[..] een immens reservoir goedkope ongeschoolde arbeidskrachten' (1983: 43). En de socioloog J.A.A. van Doorn meent dat 'men bij Maastricht waarschijnlijk kan zeggen, dat de grootindustrie voor een deel haar ontstaan dankt aan de ruime aanwezigheid van arbeidskrachten' (1947: 8).

Maar we hebben al gezien dat Regout zijn eerste werklieden buiten de stadspoorten moest halen ${ }^{15}$ : slijper, blazer, vormer en decorateur zijn

14 Zelfs in de jaren vijftig en zestig, toen de stedelijke industrie een snelle groei doormaakte, bleef het aanbod wan ongeschoolde arbeid hoog. Dat kwam doordat het gamizoen gestaag kleiner werd, parallel an het afnemende belang van de stad als vesting, die in 1867 werd ontmanteld.

$15 \mathrm{Vgl}$.: Des ouvriers habiles de differents pays furent engagés à Maestricht: des souffleurs de verre de Venise, des polisseurs de Bohème, des potiers d'Angleterre, etc. dont l'expérience et les connaissances techniques étaient évidemment d'une importance capitale non seulement pour l'introduction de nouveaux modèles, mais encore pour les méthodes de fabrication' (Economisch Archicf vam Nederland en Koloniën, 1936: 5) Misschien wordt met de vermelding van Engelse pottenbakkers ook gerefereerd aan een zekere Crisp, de deskundige die Regout rond 1845 heeft aangetrokken. 
beroepen die een betrekkelijk lange leertijd vergen. Deze geschoolde arbeiders waren in Maastricht amper aanwezig. Bij afwezigheid van beroepsonderwijs ter stede moesten lokalle arbeidskrachten door uitheemse vaklieden worden geschoold. Een belangrijk deel van het werk in de fabrieken van Regout werd verricht in groepjes van zeven blazers of vormers, onder wie vier leerjongens ${ }^{16}$, die onder leiding stonden van een maitre-outrier, ofwel meesterknecht, die de andere leden vam deze 'plaatsen' niet alleen het vak leerde, maar ook waakte over hun gedrag en taalgebruik. ${ }^{17} \mathrm{De}$ maitre-ouviler was verder verantwoordelijk voor het aannemen van de leerjongens en voor de uitbetaling van het loon.

Maar Petrus Regout besteedde niet àlle vormingswerk uit aan zijn meesterknechten. Zowel op als buiten de werkvioer betoonde hij zich zeer aktief. Hij betaalde in de beginjaren niet dagelijks of wekelijks, zoals te doen gebruikelijk, maar maandelijks uit - een systeem dat voor de stukloners tot in de jaren vijftig van de negentiende eeuw bleef gehandhaafd, met dien verstande dat zij halverwege de maand een voorschot (de kleine kizjem', naar het franse quinzaine) kregen uitgereikt, twee weken later gevolgd door een afrekening (de 'groete kèzjem'). Hij verplichtte bepaalde werklieden een tegoed op te bouwen, dat kon worden verspeeld of teruggewonnen. Hij garandeerde werk en een minimumloon voor wie minstens vijf jaar bleef. Hij stelde een verplichte spaarkas in. Hij verbood arbeiders hun eigen gereedschap mee naar huis te nemen. Hij maakte - zelfs voor die tijd - strenge reglementen, met zware geldboetes voor vergrijpen als vloeken en het onrespectvol bejegenen van opzichters. Hij verstrekte gratificaties voor goed gedrag, vlijt en trouw. Hij liet aantekeningen maken in het livret d'ouvrier, het in Nederland in onbruik geraakte 'zakboekje voor' ambachts-gezellen of maats'. Hij verplichtte leden van de ziekenkassen om de jaarmis bij te wonen voor de zielerust van de overleden leden. Hij liet een zondagsdienst instellen waar, special ten behoeve van de vele Franstalige arbeiders, in het Frans moest worden gepreekt. Hij richtte eer bedrijfsharmonie op, de Société l"Hamonie des Ouvriers Réunies, om hel bezoek van koning Willem II luister bij te zetten, en een daaraan verbonden muziekschool, die werd bekostigd uit verplichte werknemersbij. dragen. Hij stelde een conciërge aan in zijn cité ouvrièré, met de opdrach hel gedrag van de bewoners in de gaten te houden; en hij trok de huu:

16 De eerste, tweede, derde en vierde gamin.

17 Zo werkte die glasblazerij net groepen die zeven functies hadden, toegewe zen an een wattre oworier, een soufleur, een carrw, een eerste, tweede, derde e vierde gamin. De eerste gamin bevond zich op de drempel van de volwasse arbeid': hij was al lets ouder. De werkzaambeden wan de tweede, derde e vierde gamin bestonden uit het aanreiken, wegzetten of schoonmaken de voorwerpen' (Maenen, 1959: 274). 
van het loon af. Mythische proporties hebben zijn (al dan niet echt gebeurde) nachtelijke bezoeken aan zijn "onderhoorigen' in zijn fabrieken aangenomen: in nachtgewaad, de slaapmuts op en met een kaars in de hand zou hij zich over de Boschstraat hebben bewogen (Van Iterson, 1980: 20).

Zonder te willen suggereren dat deze initiatieven uit filantropische motieven voorkwamen, kan worden gesteld dat dit patroon in tegenspraak lijkt met 'de beruchte Engelse' toestanden. Wat als typisch 'Engels' wordt gezien, is een hard, cynisch liberalisme, dat zich laat samenvatten in het bekende: voor-jou-tien-anderen. Bemoeienissen - met welke bedoelingen ook - die verder reiken dan het contract warin slechts de prijs voor geleverde arbeid is vastgelegd, worden eerder geassocieerd met de meer bevoogdende Franse fabrikanten.

Brugmans verwijst naar de regeringsenquête van 1860 naar kinderarbeid (De Vries Robbé, 1860), die aan de hoofdcommissaris van de Maastrichtse politie deze uitspraak over nachtarbeid ontlokte: Met innig leedwezen ziet men hier de jeugdige fabrieksarbeiders als schimmen en in hunne opvoeding veel gelijkende naar redelooze schepselen, langs de straten loopen" (geciteerd in Brugmans, 1975: 105). De resultaten van deze enquête zijn vrijwel onopgemerkt gebleven, zoals Brugmans zelf schrijft (ibid., p. 232). In scherp contrast daarmee staat de parlementaire enquête van 1887, die eveneens de kinderarbeid als uitgangspunt had. In 1874 was het 'kinderwetje' van Sam van Houten aangenomen, dat arbeid van kinderen beneden de twaalf verbood ${ }^{18}$, en de enquête was mede ingesteld om naleving te controleren. Mede: de verhoren van de commissie bestreken het gehele scala aan 'toestanden in fabrieken en werkplaatsen'. Het onderzoek werd verricht in Amsterdam, Tilburg en Mastricht. Naast deskundig geachte onderwijzers, artsen en geestelijken kwamen ook de fabrikanten en arbeiders zelf aan het woord. De protocollen werden meteen gepubliceerd. Het waren vooral de antwoorden van de zonen van Petrus Regout die velen schokten ${ }^{19}$ en die de geschiedenis zijn ingegaan als zuivere voorbeelden van het harteloos kapitalistisch cynisme waarvan in hoofdstuk 1 al gewag is gemaakt. Zo reageerde Petrus II op vragen over nachtwerk in de blazerij door jongens: 'Och, ik weet wel dat de studenten ook wel eens niet naar bed gaan zonder daarom ziek te worden' (Giele, 1981: 215). Over de Kinderwet merkt hij slechts op dat deze de prijzen van de jongens zoveel duurder heeft gemaakt. Ook diens meer filosofische uitspraken geven weinig blijk van consideratie met hen die in

18 Er werd een uitzondering gemaakt voor huiselijke diensten en veldarbeid (Brugmans, 1975: 245).

19 Eerder al, in 1874, was er een ophefmakende brochure verschenen van J.H. Wijnen, kapelaan van de nabijgelegen St-Matthiaskerk, waarin werd beschreven hoe vaders hun zoontjes "s nachts 'schreiend' de fabriek binnendroegen. 
het donker leven: 'Alle menschen zijn in de wereld niet even gelukkig; de een heeft het harder dan de ander' (ibid., p. 206).

Volgens Recht woor Allen, het orgaan van de Sociaal-Demokratische Partij, ging 'een rilling van afgrijzen' door het land (geciteerd in Perry, 1983: 53). Louis Regout, de vierde zoon, probeerde in een open brief door nuanceringen de commotie te sussen (afgedrukt in Giele, 1981), maar dat kwam te laat: de slechte reputatie was gevestigd. Driekwart eeuw later nog zouden in Maastricht de emoties hoog oplopen toen de N.V. Koninklijke Sphinx een standbeeld van Petrus Regout wilde plaatsen. Het standbeeld is er gekomen, zij het niet op de Markt of een ander Maastrichts plein, maar op fabrieksterrein: voor de ingang van het hoofdkantoor, waar het menigmaal is beklad. En een straat of woonerf is tot op heden niet naar hem vernoemd.

In het liberalisme - of dat nu hard en cynisch is of niet - is de kerngedachte: keuzevrijheid. Wat echter eveneens oprijst uit de parlementaire enquette van 1887 (althans waar het gaat over de fabrieken van Regout) is een beeld van mechanistisch reagerende fabrikanten. Het lijkt of de zonen Regout in hun antwoorden zich pavloviaans conformeren aan het stereotype van de gewetenloze kapitalist. Ze lijken de ideaaltypische personificaties en verdedigers van het kwaad. Het is alsof ze worden gedreven door machten waarop ze geen invloed kunnen uitoefenen.

Bestonden er dan geen vrijheidsmarges? De zonen Regout lijken slechts een ontkenning van het gegeven dat men zelfs in het kwade eigen accen. ten kan leggen. En dit is met terugwerkende kracht voor Petrus I gaar gelden. Ook hij is in de legendevorming via scripties en borrelpraat eer liberale kapitalist geworden die geen andere wet kon volgen dan die vau de rechtstreekse en onmiddellijke bevrediging van zijn materiële eigen belang, wat onder andere impliceert dat arbeiders uitsluitend wordes gezien als een kostenfactor die zo laag mogelijk moet worden gehouder Deze voorstelling van zaken lijkt te simpel.

Het vermoeden dat Petrus Regout rumte heeft gehad en benut in $d$ manier waarop hij in zijn bedrijven met arbeid omging, heeft tot $d$ probleemstelling geleid waarmee het vorige hoofdstuk is afgesloten. A gezegd, in het volgende hoofdstuk schets ik de context van de opkom: van het moderne fabriekssysteem, waarna ik me in hoofdstuk 4 en 5 aa een analyse en verklaring van het probleem waag. 


\section{HOOFDSTUK 3}

\section{DE CONTEXT: \\ INDUSTRIELE REVOLUTIE EN INDUSTRIALISERING IN WEST-EUROPA}

\subsection{Inleiding}

To get things moving, any kind of appropriate incident $[. .$.$] can be$ imagined [...] it seems right that the event is small and occurs only to a few people onlly [...] Its exact nature does not much matter. It will be quickly submerged in past history"

Bensusan-Butt, D.M., On Economic Growth. An Essay in Pure Theory, Oxford: Oxford U.P., 1963: 16

De opkomst van het moderne fabriekssysteem in West-Europa is een aspect van een bredere ontwikkeling die gewoonlijk de Industriële Revolutie wordt genoemd. Dit begrip is ontstaan naar analogie van 'Franse Revolutie' (Williams, 1976: 229-30). Wie 'Industriële Revolutie' heeft geintroduceerd, is niet bekend. Het wordt meestal toegeschreven aan de Engelse historicus en hervormer Arnold Toynbee, die het in 1881 in lezingen gebruikte (verzameld in Lectures on the Industrial Revolution of the Eighteenth Century in England, 1884). Maar in het Frans en Duits duikt het begrip decennia eerder op. In Frankrijk werden 'révolution' en 'industrielle' al rond 1810 met elkaar in verband gebracht, zij het dat ze toen een andere inhoud hadden dan aan het eind van de eeuw (ibid., p. 138). Aanvankelijk verwees 'industriële revolutie' slechts naar technische veranderingen in de produktie. In de jaren dertig van de negentiende eeuw wijzigde zich de betekenis van Industriële Revolutie met de veranderde betekenis van 'revolutie'. Had 'revolutie' eerst alleen op politieke omwentelingen betrekking, in deze jaren begon men het ook te gebruiken om diepgaande veranderingen buiten de strikt politieke context aan te duiden. Zo kreeg 'revolutie' - en daarmee ook 'industriële revolutie' - de betekenis van een fundamentele verandering die een nieuwe samenlevingsorde met zich brengt.

De oudere betekenis - Industriële Revolutie als technische verandering is echter nooit verloren gegaan. Beide betekenissen bestaan tot op heden naast elkaar en overlappen elkaar ook. Een voorbeeld is de informa- 
ticarevolutie: een technische verandering die tevens een fundamentele verandering van de samenleving is.

Het is opvallend dat voor de overgang van een hoofdzakelijk agrarische naar een hoofdzakelijk fabrieksmatige produktiewijze in verschillende Aziatische, Afrikaanse en Zuidamerikaanse landen het begrip 'industriële revolutie' nauwelijks wordt gebruikt. Vaak hanteert men in het Westen hef meer neutrale 'industrialisering". ${ }^{1}$ Ondertussen blijft "Industriële Revolutie' voor wie zich met industrialisering in West-Europa bezighoudt een problematisch begrip, juist omdat 'revolutie' nog steeds óók de associatie wekt van gewelddadige omwenteling, naast die van technische en maatschappelijke verandering (vgl. Eisenstadt, 1978: 2-4, 45). Bij 'revolutie' denken nog velen in eerste instantie aan straattumult, resulterend in een bestorming. De Franse en Russische Revolutie, met de bestorming van de Bastille en het Winterpaleis, zijn de klassieke voorbeelden. In die zin zijn revoluties doorgaans beperkt tot de grenzen van een natie en een jaartal (1789, 1917). Ze betekenen een wisseling van (de) politieke macht en daarmee ook een fundamentele verandering van staatsbestel. Al gaan aan revoluties een lange tijd van onderhuidse veranderingen vooraf en hebben ze ook een lange nawerking, men kan ze met recht opvatten als drama's: bewogen keerpunten in de geschiedenis van een volk, een land.

De Industriële Revolutie vond niet plaats in een bepaald land (na Engeland volgden België, Frankrijk, Duitsland en andere landen van het Europese continent) en ook niet in een bepaald jaar (in Engeland duurde het bijna een eeuw voor deze revolutie voltooid kon worden genoemd ${ }^{2}$ ) Er werd niemand uit zijn macht ontzet of plotseling ermee bekleed. Pas na decennia van gestage opmars kon men de burgerij beschouwen als de klasse die als overwinnaar uit deze revolutie te voorschijn was gekomen Maar dramatisch is de Industriële Revolutie, in retrospectief, wel. Dt verandering was voor alle betrokkenen - niet alleen fabrikanten en arbei ders - van ingrijpende aard. De socioloog Robert A. Nisbet spreekt, in zijr schets van de Franse en Industriële Revolutie, dan ook over de 'cataclys mic nature of each' (1970: 22).

Als 'Industriële Revolutie' niet de meest gelukkige wetenschappelijke tern is, welke dan? Industrialisering'? Het beladen 'revolutie' wordt vermedeI

1 Angst om voor etnocentrisch te worden versleten, is hier misschien debr aan: als men zegt dat bepaalde landen in de Derde Wereld nú hun industriël revolutie doormaken, zegt men tevens dat ze één tot twee eeuwen achterlopen.

2 Velen nemen het jaar 1760 als beginpunt en 1830 als eindpunt; andere geven de voorkeur aan de periode 1750-1850 (zie voor een overzicht bv. Hughe 1970: 44-5). 
en door de uitgang '-isering' wordt het dynamische karakter mér recht gedaan. Maar er kleeft één nadeel aan: de historische uniciteit van de veranderingen die met 'Industriële Revolutie' worden aangeduid, raakt onderbelicht. Dat onheil lijkt groot genoeg om, met erkenning van de nadelen, hier 'Industriële Revolutie' te blijven gebruiken. Zoals E.P. Thompson het nuchter stelt: 'the term is serviceable enough in its usual connotations' (1980: 212). Dit lijkt triviaal, maar het raakt het hart van datgene waar het hier om gaat. Deze terminologische excursie is gemaakt om nadruk te leggen op het unieke karakter van de Westeuropese industrialisering - anders: om de uniciteit van de context waarbinnen de werving, behoud en beheersing van arbeid in het moderne fabriekssysteem gestalte kreeg, te kunnen accentueren.

\subsection{De Industriële Revolutie in Engeland ${ }^{3}$}

De Amerikaanse historicus William McNeill heeft er één zin voor nodig: the English Midlands and London developed the new commercial and industrial patterns - above all more extensive use of mechanically powered machinery - that we lump together as the industrial revolution" (1976: 214).

Waarom begon de Industriele Revolutie in Engeland? Een aantal ${ }^{4}$ begunstigende ontwikkelingen en omstandigheden is vaak genoemd (een overzicht geeft Hartwell, 1967). Tot de belangrijkste lijkt te horen: de geringe macht van gilde en overheid op het economische leven. ${ }^{5}$ De Engelse proto-industrie had de vrijheid om zich aan te passen aan een veranderende vraag, om te innoveren ook, en kon daardoor goedkopere produkten op de markt brengen. In de lichte industrie is van deze vrijheid het eerst en het meest geprofiteerd, omdat de slagvaardigheid van de ondernemers daar zwaarder weegt dan de beschikbaarheid en prijs van

${ }^{3}$ Deze en de volgende paragraaf zijn voor een belangrijk deel gebaseerd op The Unbound Prometheus (1969) van de Britse historicus David S. Landes.

${ }^{4}$ Met het noemen van meerdere begunstigende factoren wordt al kritiek geleverd op de 'één-oorzaaktheorieën', die de Industriële Revolutie willen verklaren met én causale factor: de uitvinding van de stoommachine, of kapitaalaccumulatie, of de bevolkingsgroei. De dwangmatigheid van de causaliteit en thet reductionisme van het voorvoegsel 'één' lijken geweld te doen aan de complexiteit en vervlechting van een veelomwattend proces als de Industriële Revolutie.

5 Zo groeide de Engelse wolindustrie in de achttiende eeuw gestaag, terwijl het daarmee in Italie, Frankrijk en Nederland bergafwaarts ging. Weliswatar genoot Engeland het voordeel de grootste leverancier van ruwe wol van Europa te zijn, belangrijker was dat de Engelse proto-industrie, ongehinderd door restricties en reguleringen, dit voordeel kon uitbuiten. 
grond-en hulpstoffert.

Andere oorspronkelijke en ontwikkelde factorvoordelen van Engeland waren: de grote toegankelijkheid van de produktiecentra tot de zee en daarmee verre markten; de langdurige vrijwaring van oorlogen; de ontwikkelde infrastructuur en de verstedelijking; de hoge sociale mobiliteit, vooral beroepsmobiliteit; de relatief hoge mate van kennis en bekwamheden van de arbeiders; de bereidheid van banken - zoals de country banks (Presnell, 1956) - tot het verstrekken van kredieten waarmee entrepreneurs hun werkkapitaal financierden (dat zelfs in de zware industrie groter was dan het vast kapitaal). Meer algemeen: de commerciële oriëntatie - een alertheid aangaande mogelijkheden rijkdom te verwerven in handel en nijverheid; de traditioneel lage onzekerheidsvermijding (zie ook Hofstede, 1980, 1991) ofwel hoge risico-bereidheid; de eveneens traditionele hoge mate van individualisme (zie opnieuw Hofstede, 1980, 1991, ook: Dahrendorf, 1982: 24-32 en: Macfarlane, 1978); de geringe macht der gewoonte - kortweg, de open tijdgeest, of: een klimaat van ondernemingszin. ${ }^{6}$

Aan de vraagzijde speelde - naast een snel groeiende binnenlandse populatie (maar dat kon men op het continent ook constateren) met groeiende behoeften (maar die deden zich op het continent ook gevoe$l^{7} n^{7}$ ) - opnieuw de afwezigheid van overerfde restricties een belangrijke rol: de bimmenlandse markt werd niet belemmerd door tolheffingen uit de feodale tijd. Van groter gewicht nog was de toegankelijkheid en groei van de buitenlandse markten. In de Oriënt, de drie Amerika's en Afrika

${ }^{6}$ Hiermee wil niet gezegd zijn dat, bijvoorbeeld, in de Middeleeuwen "hel kapitalisme' niet zou hebben kunnen opkomen, omdat de middeleeuwse gees! zich kenmerkte door nederigheid en een oriëntatie op het geestelijke en dal daartegenover het nieuwe geestelijke klimaat werd gekenmerkt door vrijheid er individualiteit en een oriëntatie op het praktische (vgl. Willems, 1977:60-1). Dezt voorstelling van zaken is te eenvoudig. Zo geformuleerd lijkt het alsof het ene geestelijke klimaat simpelweg werd vervangen door een ander. Niet alleen word voorbijgegaan aan Max Weber's inzichten omtrent juist de samenhang tusser religieuze (i.c. protestantse) ethiek en de geest van het kapitalisme (Weber, 1976) maar ook an het gegeven dat de waarden die hier aan de Middeleeuwer worden 'gekoppeld' ook nog worden beleden in latere tijden. Zo spelen in di negentiende eeuw nog feodale opvattingen - een andere middeleeuwse erfenis in arbeidsverhoudingen een rol. Paternalistische praktijken (die in hoofdstuk \& worden behandeld) waren er sterk door geinspireerd.

${ }^{7}$ Al dient gezegd dat de koopkracht en levensstandaard in Engeland reed: voór de Industriële Revolutie beduidend groter respectievelijk hoger waren dat op het continent. Engelse arbeiders aten beter, maar konden ook meer gelc besteden aan kleding, kortom: een consumptiepatroon ontwikkelen dat gunstiy was voor de groei van proto-industrie. 
ontstond een ruime vraag naar goedkope gebruiksartikelen, vooral confectie goederen.

Doordat de groei van de binnenlandse, maar vooral buitenlandse markten een op massaproduktie gerichte industrie begunstigde, constateert men vanaf het einde van de achttiende eeuw een opmerkelijke technische vernieuwingszucht, die men weer kon aflezen aan de toename van investeringen. Deze vernieuwingen - niet alleen de bekende grote uitvindingen, maar ook vele gepatenteerde micro-innovaties, die de informatie opleverden zonder welke de grote technische doorbraken niet hadden kunnen optreden (Inkster, 1988: 188 ${ }^{8}$ ) - betekenden weer een nieuwe impuls in de richting van voortschrijdende standaardisatie en daarmee produktiviteitsstijging.

Aan de aanbodzijde werden technische vernieuwingen in Engeland begunstigd door een reeds bestaand hoog nationaal niveau van technische vaardigheden, dat zijn gelijke in Europa niet kende. In de woorden van de Britse econoom Alfred Marshall: The British inventor had access to a great variety of highly skilled artisans [..] thus every experiment cost him less; and it was executed more quickly, and far more trully, than it could have been anywhere else' (1919: 62-3). Bovendien had de wijdverbreide belangstelling voor machines en werktuigen in de middenklasse, waaruit de meeste uitvinders voortkwamen (Bendix, 1963: 27), een vruchtbare institutionele bodem in een onderwijssysteem dat meer mogelijkheden tot technische bekwaming bood. Het meeste gewicht in de schaal legde het zelfversterkend effect van de industrie: The inventions came in part because the growth and prosperity of the industry made them imperative; and the growth and prosperity of the industry helped make their early and widespread utilization possible' (Landes, 1969: 66). Het is daarom moeilijk houdbaar te stellen dat technische vernieuwingen de belangrijkste - zo niet enige - oorzaak zijn geweest van het ontstaan van de Industriële Revolutie. Terecht merkt de Britse historicus $\mathbb{K}$. Bruland op: "If a conjunction of technological feasibility and need are sufficient, then how does one explain (a) the timing of British industrialisation (for most of the crucial innovations had been feasible for some time, and presumably needs also existed) and (b) the fact that Britain was first (were textile innovations not within human capabilities in France and Germany? Did they have fewer needs?) (1985: 191). Landes stelt dat, om de Industriële Revolutie voort te brengen, er een 'huwelijk' nodig was van: a) machines, die niet alleen voor een belangrijk deel handenarbeid vervingen, maar ook noodzaakten

${ }^{8}$ De Industriële Revolutie zou dan zijn begonnen in Engeland, aldus Inkster * omdat in andere landen niet op dergelijke schaal dat innovatieve gedrag werd vertoond, behalve dan na enige tijd. De oorzaak van dat gedrag in Engeland dient niet in de eerste plats te worden gezocht in vraagfactoren, maar in een serie van sociale factoren. 
dat de produktie in fabrieken moest worden geconcentreerd ${ }^{9}$ en b) een omvangrijke industrie die produkten vervaardigde waarnaar een aanzienlijke en elastische vraag bestond, zodat i) de mechanisatie van één van haar produktieprocessen een aanmerkelijke pressie op de andere processen betekende en ii) het gewicht van verbeteringen in deze industrie zich zou doen gevoelen in de hele economie (1969: 81).

Veel technische vernieuwingen waren ondenkbaar of onbruikbaar zonder de aanwending van stoom - een krachtbron, onathankelijk van natuurlijke omstandigheden als droogte, vorst en windstilte en waarmee mensen hun eigen produktiviteit meer dan honderd maal konden vergroten. ${ }^{10}$ De aanwending van stoom veronderstelde een exploitatie van steenkool op ongekend grote schaal. ${ }^{11}$ Het is volgens Landes geen toeval dat industrialisering overal opkwam waar steenkool werd gedolven, of dat de groei van kapitaal evenredig groeide met het verbruik van minerale brandstoffen. Daarmee is, opnieuw, niet gezegd dat kolen en stoom de Industriële Revolutie máákten; zij maakten alleen haar buitengewone ontwikkeling en verspreiding mede mogelijk.

Naast technische vernieuwingen wordt kapitaalaccumulatie vaak genoemd als principale veroorzaker van de Industriële Revolutie. Twijfel aan de verklaringskracht van mono-causale modellen, zoals hier is geuit, wil niet zeggen dat het reinvesteringspatroon geen belangrijke factor is geweest. Hoe opbrengsten werden benut, verklaart veel van de nationale tempoverschillen in industrialisering. Engelse industriëlen wendden hun winsten veel meer aan in investeringen dan continentale entrepreneurs, die meer in land en hypotheken belegden, of in de accumulatie van statuskapitaal (vgl. Bourdieu \& De Saint-Martin, 1978) door bijvoorbeeld een in

${ }^{9}$ Hij drukt het plastisch uit: "[.] machines whose appetite for energy was too large for domestic sources of power and whose mechanical superiority was sufficient to break down the resistance of the older forms of hand production' (1969: 81).

Deze machines zelf betekenden reeds een krachtige impuls in de richting wan massa-produktie: 'De sterke toeneming van de vaste kostencomponent noopte tot produktie op grote schaal, waardoor - anders dan voorheen = produktie moest ontstaan voor een meer anonieme markt, die inmiddels - in het begin van de negentiende eew - veelal reeds per spoorweg bereikt kan worden' (Willems, 1977: 64-5). Zie b).

10 Het accent in de stoontechnologie kwam méér op verhoging van de efficiëntie (de hoeveelheid arbeid verricht per eenheid ingevoerde energie) te liggen dan op vergroting van het vermogen van de machines (de hoeveellheid arbeid verricht per tijdseenheid); hoewel beide uiteraard met elkaar samenhingen.

11 Daar trad een 'double-loop-effect' op: de kolenmijnbouw zelf werd de grootste verbruiker van stoomenergie. 
het oog springend consumptiepatroon aan te nemen (Conspicious comsumption noemde de Amerikaanse socioloog Thorstein Veblen dat in een beroemd hoofdstuk van zijn in 1899 gepubliceerde The Theory of the Leisure Class', 1967). ${ }^{12}$ Anderzijds wordt het belang van een hoge reinvesteringscoëfficient overschat. In het laatste decennium van de achttiende eeuw, toen de industrialisering in Engeland in volle gang was, vormden de geaggrereerde investeringen slechts een bescheiden acht procent van het nationaal inkomen. Toegenomen kapitaalmobiliteit lijkt minstens van even groot belang.

Doordat Engeland deze enorme voorsprong in produktie en consumptie, in marktaandeel en logistiek, in techniek en organisatie had genomen, kreeg de Industriële Revolutie op het continent een ander verloop: er was immers een voorbeeld waaraan men zich al dan niet kon spiegelen.

\subsection{De Industriële Revolutie op het continent}

Een aantal continentale landen liep bij het begin van de Industriële Revolutie niet ver achter op technisch gebied en hun welvaartspeil was niet veel lager. In de scholing van elites waren ze Engeland zelfs vooruit. Ook voerden Frankrijk, het Habsburgse rijk en vooral Pruisen een aktieve industriepolitiek. Deze overheden richtten staatsondernemingen op, namen deel in investeringen, verstrekten leningen en subsidies, schonken belastingvoordelen, gaven technisch advies, stelden arbeidsaanbod zeker. Deze krachtige en alomvattende staatsbemoeienis kon worden uitgeoefend doordat de staat zelf centralistisch was.

Daar staat tegenover dat door de uitgestrektheid van deze continentale landen de transportkosten hoger waren en de markten meer gefragmenteerd. Dat werd tevens in de hand gewerkt door een weinig ontwikkelde infrastructuur en grotere landschappelijke obstakels. Ook werd er meer goederenbelastingen geheven, met name in Duitsland. Ongunstig was tevens de extreem ongelijke inkomensverdeling. Vooral in geisoleerde rurale streken konden de armen de consumentenmarkt niet betreden; ze

12 Reeds in de jaren vijftig en zestig hebben economen als W.J. Baumol, R. Marris en O.E. Williamson erop gewezen dat economische actoren (preciezer: managers) niet uitsluitend naar winstmaximalisatie streven, maar ook worden gedreven door andere motieven als: groei en absolute omwang van de omzet en personeelsgrootte. Deze niet-winstmotieven hebben Baumol, Marris en Williamson getracht in de neo-klassieke theorievorming te integreren. Later hebben anderen hetzelfde gedaan met betrekking tot preferentie voor bepaalde patronen van consumptie en vrije-tijdsbesteding (voor een overzicht zie: Van Witteloostuijn \& Van Lier, 1991). Aangezien het spectrum van menselijke wensen en voorkeuren breed is, kan daar nog veel werk worden verzet. 
produceerden zelf of kochten van lokale ambachtslieden. Daardoor leefde een aantal ondernemingen slechts van opdrachten van hof, kerk en haute bourgeoisie, en betraden evenmin de nationale markt.

Recrutering van fabrikanten op het continent werd belemmerd door gewoonte en wet. De aristocratie liet zich weinig met industriële aktiviteiten in." Ook in de middenklassen werd de voorkewr gegeven aan een carriere in overheidsdienst of in de gevestigde beroepen. En degenen die uit gebrek aan opleiding, gedwongen door religieuze discriminatie, of omdat er zich een bijzondere kans voordeed, tòch kozen voor handel en/of nijverheid zagen zich - naast het stigma van parvenu en buitenstaander te moeten verdragen - geconfronteerd met weerstanden van banken om kredieten te verlenen. Over kapitaal beschikten alleen degenen die het hadden geërfd of zelf geaccumuleerd. Bekwame en ambitieuze onbemiddelden vonden niet de mogelijkheden die in Engeland door de country banks werden geboden.

Daarbij kampte de ontluikende continentale industrie met andere weerstanden: eigenaars van landerijen en gebouwen wilden niet verhuren; er werden hoge belastingen geheven; er bestonden beperkende veiligheidsmaatregelen met betrekking tot nieuwe machines; delfplaatsen waren niet zelden in bezit van overheid, die hoge pachtprijzen bedong. Mercantilistische- en gildenrestricties aangaande produktie-omvang en gebruikte technieken werden aan het eind van de achttiende eeuw alleen maar strikter, ten dele uit de overtuiging daarmee de kwaliteit van de produkten te waarborgen, ten dele ondat het lucratieve bronnen van revenuen waren.

Ook de afwijkende visie op ondermemen was een obstakel voor effectief entrepreneurschap. Op het continent waren veel meer ondernemingen in familiehanden dan in Engeland en werden zij ook onverbrekelijk met die familie geassocieerd. Fusies volgden vaak op huwelijken; sterfgevallen dus erfenissen - betekenden daarentegen vaak het opsplitsen van het bedrijf in een aantal zelfstandige divisies. Voor de Britse entrepreneurs was een onderneming een middel tot een doel, een rationele manier om geld te verdienen. Men kan Engelse bedrijven als 'open' kwalificeren: Engelse ondernemers, ook degenen die zich aan hun familie gebonden wisten - waren veel meer bereid zich te associëren met vrienden of

13 Uitzonderingen daargelaten: waar landbezit een voorwaarde was tot ontplooing van industriële aktiviteiten - in de ijzer-en steenkool - nam de adel wè deel. Ook in investeringen was men niet inactief. 
vrienden van vrienden (zie ook: Clough \& Rapp, 1975: 348). ${ }^{14}$ Voor de continentale entrepreneurs was een onderneming, in relatie met de familie wier reputatie het hielp te bevestigen of vergroten, een doel in zich. Daarom hielden de Franse familiebedrijven het front gesloten. ${ }^{15}$

In continentale ondernemingen had men moeite technieken en produkten als iets onpersoonlijks te zien, om zonodig kwaliteit op te offeren voor kwantiteit, om traditionele paden te verlaten als meer efficiënte en winstgevende gereedschappen en methoden beschikbaar kwamen. Dit gedragspatroon was congruent aan de dominante waarden in de samenleving. De hoge onzekerheidsvermijding - identificatie met wat men had en weerstanden tegen vernieuwingen - bij de continentale bourgeoisie hing nauw samen met het permanente gevoel van bedreiging, gevoed door de vele oorlogen, dat een dempend effect op de experimenteerlust had. De preferentie van winstmaximalisatie per eenheid produkt boven grotere totale winst door een hogere output was in overeenstemming met een algemene veroordeling van competitie - vooral prijscompetitie - als onbillijk en zelfs subversief. De totale produktie en de totale vraag werden als een gegeven beschouwd, slechts groeiend met de bevolkingsaanwas. Je kon alleen rijk worden ten koste van je buren, die, hoe inefficiënt ze mochten zijn, het recht hadden hum positie te blijven bekleden zo lang ze produkten van acceptabele kwaliteit bleven afleveren en daarmee de behoeften van hun eigen gemeenschap bevredigden. De rijke die zijn fortuin bouwde op de ruines van minder produktieve of getalenteerde mededingers was niet een iemand die iets heeft bereikt, maar een 'mangeur d'hommes'. Wegconcurreren was uit den boze. Het onderhouden van vriendschappelijk connecties werd hoog gewaardeerd. Competitie en eliminatie waren natuurlijk miet helemaal afwezig. Niettemin werd de ruimende werking van het prijsmechanisme door de continentale waarden ernstig belemmerd. In investeringsbeslissingen had vooral de bovenmatige risico-aversie een belemmerend effect. Ook waren veel continentale entrepreneurs afkerig van vreemd kapitaal, vooral in de vorm van langlopende leningen en deelnemingen. Ze spáárden liever voor uitbreidingen.

14 Een veel voorkomende vorm van samenwerking was die van een persoon met talent en/of kennis en vaardigheden en een persoon met geld. Zo zocht Richard Arkwright financiële steun bij zijn vrouw en bij Jededial Strutt.

15 Dezelfde David S. Landes in een studie over de textielfabrikanten van Roubaix en Tourcoing: 'L. I the pace and character of French enterpreneurship was set by family firms, owned and managed by blood relabons, whose primary concerns were safety, continuity, and privacy (1976: 42). Landes spreekt van een patriciaat aan elkaar geklonken door gemeenschappelijk economisch belang, uniforme opwoeding en huwelijken - een "[..] remarkably homogenous, highly con" formist, mutually sustaining cousinhood" (ibid., p. 63). Tegenover het Engelse individualisme steken deze waarden en praktijken als collectivistisch af. 
Aan het einde van de achttiende eeuw waren or op het continent slechts een paar uitzonderingen op de louter voor de lokale semi-autarke markt, op kleine schaal producerende fabrikanten. Een paar industrieèn, zoals bepaalde takken van de chemische industrie en de metaalindustrie, waren om technische redenen tot produktie op grotere schaal gedwongen. Ook in de wolindustrie kwam een aantal fabrieken (in Frans-Vlaanderen, Verviers, Saksen, Normandië en de Languedoc) tegemoet aan een vraag die niet door de streekgrenzen werd beperkt. Het waren de centra die het minst te maken hadden met gildenrestricties die het hardst groeiden (vgl. Braverman, 1974: 60). De Luikse wolindustrie, bijvoorbeeld, altijd door de gilden gecontroleerd, ging gestaag neer. Maar in Verviers, waar geen gildenrestricties golden, ging het de beginnende wolfabrikanten voor de wind. In Aken dreef regulatie de meest belovende ondernemers naar de periferie van Burtscheid, waar groei kon worden geconstateerd (Bruckner, 1949).

Voor de industrie betekende de Franse Revolutie aanvankelijk slechts verlies van arbeid en kapitaal, inflatie en politieke instabiliteit. ${ }^{16}$ De achterstand op Engeland werd groter. De meeste continentale fabrikanten werden daardoor eerder ontmoedigd dan uitgedaagd. De continentale familiebedrijven werden, door tegenslagen als inflatie, grondstoffentekorten en terugvallende vraag geplaagd, nog banger om te mislukken. Ten tijde van de Restauratie bleef die angst groot. Ze durfden niet de allermieuwste machines te kopen om daarmee de Engelsen voorbif t $t$ streven. Omdat het continent na de val van Napoleon opnieuw een staat kundige lappendeken werd, waardoor de markt weer versplinterde er handelsbarrières terugkeerden, werd het inhalen van Engeland's voor sprong moeilijker ná het Congres van Wenen dan ervóór. De kloof ir techniek was groter geworden en de sociale, economische en culturel obstakels voor imitatie of verbetering waren gebleven.

Wegwerking van deze obstakels van de kant van de staat, maar mee nog van de kant wan de fabrikanten kleurde de sociaal-economisch continentale geschiedenis van de eerste post-napoleontische decennia. $\mathrm{He}$ gebrek aan technologische know-how werd vooral bestreden met he kopen van Engelse machines (of onderdelen) en het (aanvankelijk doc

16 Daar stat tegenover dat een aantal traditionele belemmeringen van c mobiliteit van kapitaal en arbeid werden afgezwakt of opgeruimd, zaals de g: den, die in 1791 in Frankrijk werden afgeschaft. Tet verval van het gildenstelse: intern al geplatgd door overregulering en nepotisme - heet de komst van a Industriele Revolutie zonder twrifel begunstigd. Maar zoals in het vorige hoof stuk al is aangestipt, is de organisatiestructuur van de gilden in sommige (sem moderne fabrieken overgenomen: kleine produktie-eenheden met een systee van meester en leerlingen als, on zo te zeggen, ambachtelijke eilanden. 
Engeland verboden) inhuren van Engelse expertise. ${ }^{17}$ In 1825 waren al 2000 Britse technici en geschoolde arbeiders op het continent werkzaam, waardoor een direkte overdracht op de werkvloer van technische kennis en bekwaamheden mogelijk werd gemaakt. Op de lange termijn was de komst van het lager, middelbaar en hoger technisch onderwijs ${ }^{8}$, van staatswege gefinancierd, van groter belang in de groei naar technologische onafhankelijkheid. ${ }^{19}$ Naast scholen betekenden exposities veel voor de verspreiding van technologische kennis.

Zo vormde zich in de eerste decennia van de negentiende eeuw geleidelijk toch een groep entrepreneurs met het talent, de wilskracht en bekwaamheid om de motor te vormen van de continentale Industriële Revolutie. Zij wisten profijt te trekken uit de institutionele en economische veranderingen na 1815, waar nog bij kwamen: infrastructurele verbeteringen en verruiming van kredietmogelijkheden via de overheid, de aandelenmarkt en speciaal daartoe opgerichte banken (eerst in België, daarna in Frankrijk en vervolgens, het meest verspreid, in Duitsland).

Tussen 1850 en 1873 maakte de industrialisering op het continent een ongekend snelle groei door: er traden veei (ook buitenlandse) bedrijven toe, bestaande bedrijven breidden zich uit, wettelijke bepalingen aangaande het vrije ondernemen werden verruimd, tarieven tussen leidende landen werden verminderd, in de textielindustrie werd vrijwel volledig en definitief overgestapt op het mechanisch aangedreven weefgetouw, in de ijzerindustrie op toepassing van minerale brandstoffen en de stoommachine verscheen in vrijwel alle fabrieken, de macht der gewoonte, belichaamd in traditionele instituties, holde verder uit en het optimisme in een vrije kapitalistische produktrewijze nam toe. Landes: "It was as though the very expansiveness of the economy, the general euphoria of growth and prosperity, had persuaded nations and people to let their guard down, to trade control for freedom, parochialism for universalism, tradition for change, the safety of exclusiveness for the danger yet potential profit of the open world' (1969:200).

17 Zo was de revolutionaire steenkooloven, waarop direkteur Kemlin van de Val St.-Lambert als eerste patent verwierf, gebouwd met de hulp van Engelse deskundigen (Chambon, 1955: 169-70).

18 Op het middenniveau kan men denken aan de Duitse Gewerbeschule en de Franse Ecoles des arts et métiers; op hoog niveau aan de Franse Ecole Polytechnique, aan het Berlinse Gewerbe-Institut en het Pruisische Hauptbergwerks-Institut.

19 Door de hoge initiéle kosten en de niet-meteen-zichtbare baten konden entrepreneurs zich slechts permitteren steun te verlenen aan scholing op lager niveau, waar men in korte tijd werden geprepareerd voor het fabriekswerk. 
Evenaring, in kwantitatief opzicht, van de industriele produktie van Engeland werd pas later bereikt, en slechts in enkele sectoren. Ook in schaal en effucientie van produktie werd Engeland vooralsnog niet ingehaald noch in de mate van industrialisering zelf. De Engelse Industriele Revolutie was rond 1850 immers pas voltooid - het moment dat de continentale landen hun inhaalmanoeuvre begonnen. Maar Engeland's groeicapaciteit nam af en die van de continentale landen toe, zodat ten slotte België, Frankrijk, Duitsland en ook Nederland op sommige gebieden met Engeland konden wedijveren, of het zelfs overvleugelen.

\subsection{De Industriële Revolutie in de Lage Landen: de ongelijke verdeling}

De factoren die hier zijn aangedragen ter verklaring van de verschillen in industrialisering tussen Engeland en de continentale landen kunnen slechts voor een deel worden herkend in de ongelijke ontwikkeling tussen de Noordelijke en de Zuidelijke ${ }^{20}$ provincies van het Koninkrijk der Nederlanden. Beide - Engeland vs continent, België vs Nederland - zijn belangrijk wil men de geschiedenis van de fabrieken van Petrus Regout begrijpen

Waarom was België het eerste Westeuropese land waar de Industriële Revolutie begon en Nederland het laatste? Dit probleem is des te boeiender, omdat beide landen op een aantal punten op elkaar lijken. Ze zijn ongeveer even groot, liggen beide aan zee, in dezelfde geografisch bevoorrechte hoek van Europa en ook in demografisch opzicht komen ze overeen. Hieronder zal voornamelijk de gedachtengang worden gevolgd die de Amerikanse econoom Joel Mokyr heeft ontwikkeld in zijn vergelijkende studie Industrialization in the Low Countries, 1795-1850 (1976). ${ }^{21}$

In de achttiende eeuw was de economische situatie voor de Noordelijke Nederlanden (gemakshalve zal verder met terugwerkende kracht Neder-

20 Inclusief het prins-bistom Luik.

21 Mokyr meent ook dat Nederland en Belgie in politiek sociaal en cultureel opzicht veel op eikaar leken, maar daar wil hij teveel ceteris parbus bereiken. Zo noent hij de Noderlandse taal die op Wallonie na in beide landen wordt gesproken, maar dan gaat hij voorbij aan de diepgaande verfransing van Vlaanderen die pas na de Tweede Wereldoorlog werd gekeerd. Tot die tijd was het Frans de taal van de overheid, de hogere klassen en het secundair en hoger onderwijs. De grote scoreverschillen op de rationale cultuurdimensies van Hofstede wijzen eveneens al in een andere richting - sterker nog: [...] no two countries [..] with a common border and a common language are so far culturally apart [..] as Belgium and the Netherlands' (1980: 335) 
land" en 'België' worden gebruikt) verre van ongunstig. De achteruitgang wan de Republiek is te dramatisch afgeschilderd - te diep betreurd in eigen land, te luid toegejuicht in het buitenland. Tot 1795 was de neergang van handel en zeevaart slechts relatief. Het comparatieve voordeel dat de Republiek in de zeventiende eeuw genoot, werd, mede door een effectieve tariefpolitiek van de grootste concurrenten, Engeland en Frankrijk, rechtgetrokken. Na een verstoring door een klein, ondernemend land werd een nieuw evenwicht bereikt. Handel en zeevaart in de achttiende-eeuwse Republiek vertoonden geen achteruitgang, maar stagneerden. De trafieken, waar ruwe goederen werden bewerkt of verfijnd, stagneerden door lhun afhankelijkheid eveneens. De manufacturen vertoonden in die tijd wèl al een absolute neergang. De Leidse wolindustrie, de Delftse aardewerkindustrie en de Zaanse zaagmolens maakten een zware crisis door. Oorzaak: opnieuw de Engelse en Franse tariefpolitiek en, belangrijker, het niet overnemen dan wel mislukken van technische vernieuwingen.

Commerciële stagnatie en industriële neergang deden velen hun heil zoeken in kapitaaltransakties. De gewezen grote handelsmogendheid ontwikkelde zich tot een renteniersstaat' (De Vroede, 1981: 11). Deze ontwikkelingen ten spijt ging Nederland de negentiende eeuw binnen met een ormvangrijke nijverheidssector, zij het een kwetsbare, éen die gekenmerkt werd door stagnatie (de trafieken) en neergang (de manufacturen). Deze sector was voomamelijk geconcentreerd in de maritieme provincies, zoals Mokyr ze noemt, in het bijzonder de beide Hollanden. In de perifere prom vincies was nijverheid zo goed als afwezig.

De landbouw - naast handel en zeevaart de derde pijler waarop de welvaart van de Republiek rustte - bleef ook in de achttiende eeuw in de maritieme provincies op een ongekend hoog peil. De zandgronden van de perifere provincies waren ongeschikt om deze geavanceerde agricultuur over te nemen. Samen met de afwezigheid van fabrieken draagt dit bij aan een verklaring voor het ontstaan van huisindustrie in, met name, Twente en Noord-Brabant. Bij teleurstellende landbouwopbrengsten was huisindustrie de enige alternatieve bron van inkomsten.

België stond er in de vroeg-moderne tijd minder gunstig voor. De Spaanse overheersing in de zeventiende eeuw had desastreuze effecten op de bloeiende economieën van Brabant, Vlaanderen en de Waalse provincies gehad. Huurlegers hadden het land verwoest, hoge belastingen de economie. Door de onderdrukking van de protestanten waren veel ambachtslieden naar het Noorden gevlucht. Ook de afsluiting van de Schelde door de Republiek had een klap toegebracht. Later werden nog de oorlogen van Lodewijk de Veertiende op Belgisch gebied uitgevochten.

Toen de Zuidelijke Nederlanden in 1713 Oostenrijks werden, trad er een langzaam herstel in. Door de introductie van de aardappel en nieuwe landbouwtechnieken nam de produktiviteit in de landbouw toe en daar- 
mee ook de plattelandsbevolking (in de steden bleef deze nagenoeg gelijk). Dit was de grote stimulans voor de groei van de proto-industrie" , die een verdere toename van de bevolkingsomvang mogelijk maakte, maar ook cruciaal was voor de ontwikkeling van België als industrieland. De centra van Zuidnederlandse proto-industrie waren de Vlaamse linnenindustrie, de wolindustrie in de vallei van de Vesdre (Verviers) en de melaalindustrie in Luik, Namen en Henegouwen. In de linnenindustrie werkten halverwege de achttiende eeuw wel 250.000 spinners en wevers. Het uitbesteedsysteem heeft er zich niet ontwikkeld: doorgaans werden alle werkzaamheden verricht in economisch zelfstandige gezinnen. Het moderne fabriekssysteem kwam in deze tak wan nijverheid pas in de negentiende eeuw tot ontplooiing, enkele decennia na een ingrijpende crisis aan het eind van de achttiende eeuw.

De wolindustrie in en rond Verviers (verderop uitgebreider behandeld) groeide in de achttiende eeuw langzamer dan de linnenindustrie; er werkten ook minder arbeiders op het totaal van de regionale bevolking. Maar hier komt vanaf de tweede helft van de eeuw wèl concentratie op gang. Fasen in het produktieproces, zoals het kaarden, schonen, verven en weven, werden in toenemende mate in één ruimte verricht, zodat men gebruik kon maken van de watermolens die langs de Vesdre werden gebouwd. ${ }^{23}$ De wevers werden ook bij elkaar gezet om verduistering tegen te gaan en kwaliteitscontrole te vergemakkelijken. Bovendien drukte concentratie de 'overhead'-kosten, zoals verwarming en verlichting, en konden er bepaalde belastingvoordelen worden behaald. Niettemin bestond de wolindustrie rond 1800 nog voornamelijk uit huisindustrie. Spinnen geschiedde uitsluitend ruraal; weven nog voor 40 procent. Dit huisindustriële werk werd verricht om dezelfde reden die Twentse, Noord-Brabantse en Vlaamse boeren ertoe dreef: om tegenvallende opbrengsten op te vangen. De ruwe wol werd geïmporteerd uit Spanje en het eindprodukt werd grotendeels weer geëxporteerd op een competitieve

22. De protomindustrie werd ook nog bevorderd door het bestaan van een tot de Middeleeuwen teruggande traditie van huisindustrie in de wolproduktie in Vhanderen, de anwezigheid van vruchtbare grond voor vlasindustrie in OostVlaanderen en het bestaan van een traditionele band met Spanje, die de mogelijkheid gaf op de Spanse markt en die van haar koloniën af te zetten.

23 Waarmee niet is gezegd dat dit een eanvoudig proces was. De vroege gedeeltelijke mechanisering is des te verwonderlijker als men bedenkt dat dit ir de wolindustrie nog moeilijker was dan in de katoenindustrie. Dit kwam, onde] andere, door de eigenschappen van de vezel. Mechanisering van het spinnen was nog het minst gecompliceerd - zodat er begin jaren twintig van de negentiend eeuw nog slechts in enkele achtergebleven streken op het wiel of de "jenny" werc gesponmen - maar het weven leverde grote problemen op. De lage loonkosten eI de Engelse concurrentie waren een nog groter obstakel voor mechanisatie. 
wereldmarkt, die de Vervierse fabrikanten dwong prijsnemers te worden. Dankzij de lage lonen konden zij marges behalen.

Weliswaar bestond er in de Vesdrestreek een traditie in wolproduktie, maar doordat Verviers, als gezegd, geen gildentraditie kende, hoefde de moderne wolindustrie geen lokale concurrentiestrijd te voeren. In de stad heerste een absolute ondernemersvrijheid. Men kan de industrialisering van Verviers beschouwen als een bijna zuiver experiment van ongehinderde ontwikkeling van een aantal lokale kapitalistische organisaties. ${ }^{24}$

Aan het einde van de achttiende eeuw kwam het familiebedrijf BiolleySimonis als leidende wolfabrikant uit de competitie. Het assortiment kaard- en spinmachines dat William Cockerill ${ }^{25}$ in 1798 voor de som van 25.000 francs aan de fabriek leverde, werd, hoe primitief ook, een groot succes. Het contract dat Cockerill met Biolley-Simonis had gesloten, hield in dat hij zich aan geen andere firma mocht verbinden. Maar de winsten voor Biolley-Simonis waren zó groot dat niet kon worden verhinderd dat de vindingen zich snel onder de lokale concurrenten verspreidden. Over hoe dat precies ging, verschillen de anecdotes (vgl. Lebrun, 1948, met Henderson, 1965: 109). In 1812 waren er al 21 producenten van textielmachines in de provincie, met 2578 arbeiders, die in dat jaar 3062 spinmachines voor fijne draad, 554 voor grove draad, 554 kaardmachines, 1650 knipmachines en verschillende andere mechanische werktuigen vervaardigden. De input van arbeid kon door deze mechanisatie met bijna tweederde worden verminderd. Bij een min of meer gelijk blijvend aantal arbeiders kon een grote produktiviteitstoename worden gerealiseerd. Niettemin werden oudere produktiemethoden niet meteen terzijde geschoven: in 1812 waren slechts zes van de 144 wolfabrikanten overgegaan tot aanwending van het gehele Cockerill-assortiment, al hadden de meesten wel één machine - doorgaans diens 'flying shuttle' - opgesteld.

Vooral in het eerste anderhalve decennium van de negentiende eeuw

24 Het marktmechanisme wekte in het Vervierse nog de meeste weerstand onder de arbeiders. Met name in de achttiende eeuw was er veel arbeidsonrust. Tussen arbeiders die in de stad woonden (en dus in de ateliers werkten) en degenen die op het platteland woonden (de thuisspinners en-wevers) botste het herhaaldelijk.

Toen de stadswevers zonder werk kwamen, eisten ze het alleenrecht op weefarbeid ten behoeve van de Vervierse fabrieken en het verbod om werk aan plat" telandswevers a an te bieden. Omgekeerd is het ook voortgekomen dat plattelandsarbeiders de stad introkken en de arbeiders daar dwongen hun werk te verlaten.

25 Voor een biografie wan William Cockerill zie: Henderson, 1965. In 1807 vestigde hij zich in Luik, waar hij een atelier voor textielmachines opende. In 1812 had hij al 2000 arbeiders in dienst. Zijn jongste zoon, John Cockerill, werd de meest prominente figuur in de Luikse machine-jndustrie. 
krijgt, mèt de mechanisering van het weven, de trend naar centralisatie van produktie, en daarmee urbanisering van rurale arbeiders, nog meer gewicht. Het weefgetouw met flying shuttle (die de produktiviteit van de wever verdubbelde) was vier keer zo duur als oudere modellen: 400 francs, ongeveer gelijk aan het bruto jaarloon van de gemiddelde wever. Thuiswevers moesten daarom wel naar de fabrieken komen omdat dit nieuwe weefgetouw voor hen onbetaalbaar was. Maar het bleek moeilijk vakarbeiders binnen de fabrieksmuren te houden. In een enquête uit 1816 beklaagden Vervierse wolfabrikanten zich erover dat ze hun geschoolde krachten nauwelijks wan emigratie konden weerhouden en ze verzochten de overheid maatregelen te nemen.

Het verlies van de Franse markt was een aderlating. Pas in 1830, toen nieuwe afzetmarkten als de Verenigde Staten en, dank zij koning Willem I, het Nederlandse leger waren gevonden, werd het peil van rond 1812 weer bereikt. Door deze langdurige inzinking wierpen de technische vernieuwingen niet optimaal hun vruchten af. De eerste stoommachine werd geintroduceerd in 1816 (aanvankelijk werd stoom alleen gebruikt om de glans van de wol te halen), maar pas vanaf het midden van de jaren twintig vond deze vorm van mechanische aandrijving wijdverbreide toepassing. Begin jaren dertig kon de afhankelijkheid van Engeland op technisch gebied als verleden tijd worden beschouwd.

In de proto-ijzerindustrie rond Namen en Luik en in de provincie Henegouwen, die rond 1800 werk bood aan tienduizenden arbeiders, werden voornamelijk kleinere produkten vervaardigd, zoals spijkers en gespen. Net als in Vlaanderen was het hele gezin bij de produktie betrokken en waren de lonen laag. Ook de produkten van deze proto-ijzerindustrie waren voornamelijk bestemd voor de export.

Resumerend: terwijl de hele Belgische proto-industrie zich kenmerkte door gerichtheid op export, lage lonen en participatie van plattelandsbevolking die tegenvallende agrarische opbrengsten moesten compenseren, bestonden er opmerkelijke verschillen in de organisatie van arbeid: het werk werd verricht in economisch zelfstandige arbeidersgezinnen, in van uitbesteders afhankelijke gezinnen en in fabrieksruimten.

Doordat de Nederlandse visvangst en zeevaart ernstig werden belemmerd door de Napoleontische oorlogen en de Britse blokkade van de Bataafse Republiek, ondervond ook de daarvan afhankelijke nijverheid een terugslag. De stagnatie verkeerde in neergang. Maar dat kan niet verklaren waarom de Nederlandse industrieën zich na de Franse tijd niet aanpasten aan de veranderde techniek. De papier-, textiel-, tabaks- en jeneverindustrie, en aanvankelijk ook de scheepsbouw, raakten in de wersukkeling. De suikerraffinaderijen vormden een uitzondering; daar werd vrij spoedig stoomkracht ingeschakeld. De enige nieuwe industrie in de jaren twintig werd gevormd door de machinefabrieken van G.M. Roentgen in Rotter- 
dam en Paul van Vlissingen in Amsterdam. Maar beide fabrieken werden kunstmatig in leven gehouden en die van Roentgen bleek snel een fiasco. Overheidssteun aan de textielindustrie in het westen mislukte eveneens.

De economisch-historicus I.J. Brugmans $(1925,1975)$ heeft de balans opgemaakt van de Nederlandse industrialisering vóór 1820. Zijn bevindingen in trefwoorden: géén stoommachines, géén export, géen produktie afgestemd op een onbekende markt, géén levering op voorraad, géen consequent winststreven, géén rationalistische levenshouding. Rond 1825 werkten, op een beroepsbevolking van ongeveer 1 miljoen 38.000 mensen in het midden- en grootbedrijf (waartoe ook nog de thuiswerkers werden gerekend): 12.000 in de westelijke provincies, 26.0000 in de perifere provincies (De Jonge, 1971: 212). Men mag concluderen dat in het eerste kwart van de negentiende eeuw de nijverheid stagneerde of slechts een geringe stijging te zien gaf (De Meere, 1982, samenvatting hoofdstuk 1, par. 4).

Tot 1850 bleven bedrijven met minder dan tien arbeiders overheersend. Van fabrieksmatige produktie en aanwending van stoomkracht was ternauwernood sprake: in 1837 waren er slechts 37 stoommachines in werking, in 1853 waren er dat nog niet meer dan een schamele 400 (voornamelijk in katoenspinnerijen, suikerraffinaderijen en de diamantnijverheid). Men bleef vrijwel volledig op bestelling werken, naar ambachtelijke methodes, voor de lokale of binnenlandse markt. Niettemin kan er in sommige bedrijfstakken een produktiestijging worden geconstateerd, zoals in de bouwnijverheid, de kleding- en textiel, de schoen- en leernijverheid, de metaal en de scheepsbouw en de voedings- en genotmiddelenindustrie (Griffiths, 1979: 189).

Twente was een geval apart. De proto-industrie in dit gewest was redelijk gespaard gebleven van de beproevingen van de Franse tijd. Al in de eerste decennia na 1815 kon men de traditionele produktie aanmerkelijk verbeteren. Dat modernisering van de produktietechnieken achterwege bleef, moet ten dele worden gezocht in het beleid van de Nederlandsche Handelmaatschappij, dat, op advies van de Engelsman Ainsworth, was gericht op handhaving van de traditionele methoden. De firma Spanjaard te Borne, bijvoorbeeld, stapte pas in 1865 over op mechanische weefgetouwen. Ook een als voorloper beschouwde firma als Salomonson ging pas in de jaren vijftig mechaniseren.

In de Noord-Brabantse proto-nijverheid liep de Tilburgse wolindustrie voorop. In 1809 al werden er twee assortimenten van Cockerill geinstalleerd, waarmee mechanische wolbewerking in het Noorden werd geintroduceerd. Na een periode van neergang, ingezet in 1813, werd in 1827 de eerste stoommachine in gebruik genomen. Ondanks vertraging en terugval zijn in Twente en Noord-Brabant in de jaren dertig en veertig de fundamenten gelegd voor een moderne textielindustrie. 
Mokyr noemt als eerste ware modeme industrieen in Nederland: de suikerraffinaderijen en scheepsbouw in het Westen, de wolindustrie in Tilburg en de glas- en aardewerkindustrie in Maastricht. En De Jonge noemt als 'industriële enclaves' rond 1850: 'enkele toenmalige moderne ondernemingen in de metalnijverheid, voorts de ondernemingen van Regout te Maastricht, alsook de suikerraffinaderijen' (1976: 245).

Daarna kwam het grootbedrijf aarzelend op gang in de gasfabricage, de diamantnijverheid, de ijzergieterijen, de papierindustrie, de broodbakkerijen en, nog iets later, de aardappelmeelfabrieken (Brugmans, 1975: 335). Maar het zou overdreven zijn te spreken van een structurele macroeconomische verandering in het produktieproces. "Het beeld dat van de periode 1814 - 1850 blijft hangen is dat van stagnatie, van kwijnende welvaart, van oude vormen, van een volkshuishouding in een vroegkapitalistisch stadium' (Fischer, 1983: 11).

In de jaren tussen 1799 en 1810/11 werd in de Zuidelijke Nederlanden en het prinsbisdom Luik - al vanaf 1795 bij Frankrijk ingelijfd - een sprong voorwaarts gemaakt. Van de continentale landen industrialiseerde België in het hoogste tempo. Na een korte depressie van 1814 tot 1820 , toen het Zuiden bij het Koninkrijk der Nederlanden werd gevoegd, trad er opnieuw een periode van technische vernieuwing en groei van vast kapitaal in. Ook de neergang in de jaren dertig, een nevenwerking van de Belgische Opstand, was van voorbijgaande aard. Niet alleen in de industrie, maar ook in de handel, het transport, het geldverkeer en de landbouw kan er in deze periode tot 1850 een opmerkelijke groei worden geconstateerd (vgl. Coppejans-Desmedt, 1955: 261-86).

Naast Verviers werd Gent een speerpunt in de Belgische Industriële Revolutie, met als grote pionier de katoenfabrikant Lieven Bauwens (voor een biografie zie: Leleux, 1969; voor een levensschets: Nationaal Biografisch Woordenboek, 1964: 98-107). In 1801 richtte hij de eerste moderne spinfabriek van de Lage Landen op. In 1812 al waren in de hele Vlaamse katoenindustrie, geconcentreerd in Gent, 10.000 mensen werkzaam. Ondanks Bauwens' monopoliestreven waren spoedig concurrenten toegetreden. Ook deze industrie kenmerkte zich door een export-georiënteerdheid.

Enige jaren later ontwikkelde zich rond Luik en Namen en in Henegouwen uit de proto-industrie een moderne zware industrie. De ijzergieterij kwam voornamelijk op in Henegouwen en Namen; de produktie van wapens, machines, spijkers en spoorwegrails rond Luik, waar men vooral bij de wapenfabricage kon profiteren van een oude ambachtelijke traditie. In deze industrie, mér nog dan in de textielindustrie, waren in het bedrijf teruggestorte winsten de belangrijkste kapitaalbron.

Naast de klassieke fenomenen van accumulatie van kapitaal en concen- 
tratie van arbeid, technische vernieuwing in gereedschappen en machines, snel groeiende, voornamelijk buitenlandse afzetmarkten en een groep gedreven en bekwame entrepreneurs lijkt de Belgische vroege Industrièle Revolutie zich te kenmerken door een opvallende rekrutering van arbeid: deze kwam waarschijnlijk grotendeels uit de proto-industrie. Het is tenminste opmerkelijk dat de moderne industrieën opkwamen in streken waar de proto-industrie ver ontwikkeld was: in Oost-Vlaanderen en rond Charleroi, Luik en Verviers. Ook opmerkelijk is dat deze traditionele nijverheid, zoals de Vlaamse linnenfabricage, naast de moderne industrie bleef voortbestaan en het enkele decennia redelijk wist vol te houden. In de eerste helft van de negentiende eeuw nam het relatieve belang van de textielindustrie af, waardoor het zwaartepunt van de Belgische industrie werschoof van Gent en Verviers naar Luik en Henegouwen. Toch was de textielindustrie halverwege de eeuw nog verreweg de grootste werkverschaffer.

Hoe is de geschetste ongelijkheid in industriële ontwikkeling tussen België en Nederland te verklaren? Bij afwezigheid van vergelijkbare gegevens over beider bruto nationaal produkt, of van wat als een schatting daarvan kan worden gebruikt, heeft Mokyr de ongelijke ontwikkeling afgelezen van indirecte indicatoren. In 1850 was de export-import ratio van voedsel in Belgiè 0.46 en in Nederland 1.42, maar de export-import ratio van fabrikaten was 2.64 in België tegen 0.43 in Nederland (voor wat betreft ruwe materiallen waren de ratio's resp. 1.16 en 0.40). Een andere door Mokyr uitgerekende ratio is het aantal aangewende stoommachines. Deze was, eveneens in $1850,1: 5.2 .^{26}$ Een derde indicator is het aantal prijzen dat op de Wereldtentoonstelling van 1851 werd verworven. De ratio Nederland-België was $1: 6$.

Ook Mokyr is een aanhanger van een 'éen-oorzaaktheorie": hij beschouwt accumulatie van kapitaal als de belangrijkste drijvende kracht wan de Industriële Revolutie. Als cruciale variabele van deze kapitaalaccumulatie ziet hij de inkomenswerdeling: als de lonen laag zijn, verloopt het proces van industrialisering snel; zijn ze hoog, is het industrialiseringstempo laag. De lonen in België waren gemiddeld aanmerkelijk lager dan die in Nederland. Dat us niet verwonderlijk, want de lonen in Nederland waren en bleven in de eerste helft van de negentiende eeuw hoog dankzij, onder meer, de hoog ontwikkelde armenzorg (die het arbeidsaanbod zou drukken) en de hoge arbeidsproduktiviteit in de landbouw (nog steeds

26 Houdt men rekening met de capaciteit dan zakt de verhouding tot 1:3.1, ondat in de Nederlandse scheepsbouw een aantal zware stoommachines werd gebruikt. 
hoger dan waar ook op het continent). ${ }^{27}$ In 1819 lag het gemiddelde loon in de noordelijke provincies van het Koninkrijk 56.5 procent hoger dan in de zuidelijke. Vooral de maritieme provincies sprongen eruit. $\mathrm{Na}$ een abrupte verhoging rond 1800 stabiliseerden de lonen in de zuidelijke provincies zich daarentegen op hun relatief lage niveau, omdat daar de bevolkingsgroei wèl een toenemend arbeidsaanbod betekende, terwijl ook de uitbreiding van de Engelse textielproduktie (vooral katoen) zich deed gevoelen.

Alternatieve hypothesen over de ongelijke ontwikkeling verwerpt Mokyr. Verschillen in aanwezigheid van natuurlijke bronnen acht hij niet van wezenlijk belang. Weliswaar had België ijzer- en kolengebieden, maar Nederland had wind en turf als energiebronnen en bovendien was het belang van kollen en ijzer in de industrie vóor 1850 niet zo groot. In de textielindustrie was het percentage kosten uitgegeven aan brandstoffen zeer laag: in de Vervierse wolindustrie nog geen twee procent.

De verschillen in overheidsbeleid tussen beide landen vindt Mokyr eveneens van ondergeschikt belang. Over de industriepolitiek van Koning Willem I (vgl. Demoulin, 1938) merkt Mokyr op dat de 'kanalenkoning' juist in België investeerde omdat het daar méér opbracht (en niet andersom).

Een terechte opmerking of niet, het is onbetwistbaar dat ná de afscheiding de (voorlopige) Belgische regering een aktieve industriepolitiek ging voeren. In 1834 werden hoge protectietarieven ingesteld ${ }^{28}$, in 1835 werd, naast de Société Générale, de Banque de Belgique opgericht, waarmee verstrekking van langlopende kredieten aan de industrie werd uitgebreid, en het spoorwegnetprogramma werd gesubsidieerd. Tussen 1834 en 1850 werd 861,4 kilometer spoorlijn aangelegd. Voorts werden er nog enkele kanalen gegraven: het Canal de la Campine en het Kanaal Maastricht Luik.

De Société Générale - een van de eerste bank n.v.'s ter wereld, in 1822 opgericht door Koning Willem I - ging, na de benoeming door de voorlopige regering van een nieuwe directeur, in de jaren dertig behalve als

27 Zowel de hoog ontwikkelde armenzorg als de zorg voor de ontwikkeling en instandhouding van een hoogwaardige landbouw ziet Hofstede in het licht van de extreem hoge score van Nederland op femininiteit (een masculiniteitsscore van slechts 14; alleen Noorwegen en Zweden scoren feminiener)(1987: 11).

28 Vanaf 1815 al werd er binnen het nieuw gevormde Koninkrijk gestreden tussen voor- en tegenstanders van protectionisme, van wie de eersten voornamelijk in de zuidelijke provincies waren te vinden en de tweeden voornamelijk in het Noorden. De Tariefwet van 1822 was een kleine triomf voor het protectionisme. Na de afscheiding ging België voort op de protectionistische koers en Nederland op de vrijhandel. 
kredietverlener ook als voertuig dienen varn fusies en stichting van nieuwe bedrijven. Weldra begon de Société kleine familiebedrijfjes in grotere eenheden samen te smelten, die de n.w.-vorm kregen en van dat punt naar de oprichting van nieuwe n.v.'s was het maar een kleine stap. Daarmee was de Société in korte tijd geëvolueerd naar de zogenaamde industriepromotie, een tot nog toe ongekend intensieve vorm van bemoeienis' (Buist. 1978: 217). Dat deze politiek succes had, bewijst het voorbeeld van de glasindustrie. In 1836 ging de Société nationale pour entreprises industrielles et commerciales, een dochter van de Société, over tot de vorming van de Societé Anonyme des Manufacture de glaces, verres à vitres, cristaux et gobeleteries. Hierbij werd de Val St. Lambert gefuseerd met de glasfabriek van Mariemont, opgericht in 1828. In de jaren daarna kwamen de meeste andere Belgische glasfabrieken erbij. In die tijd bestonden er, naast de Société Générale zelf en een aantal verzekeringsmaatschappijen, nog maar weinig naamloze vennootschappen in België (de eerste dateerde van 1819) en het mag opvallend heten dat de Belgische glasindustrie zo snel uit de beslotenheid van de familiebedrijven werd getrokken. De export van glas groeide onstuimig: van een jaargemiddelde van 820.000 francs in de jaren. 1831-35 steeg de export naar een hoogte van 13.698.000 francs in de jaren 1846-1850 (Mokyr, 1976: 77). Tegen 1850 was België de leidende glasproducent van het continent, een gegeven dat Regout's concurrentiepositie niet onberoerd liet.

Daartegen stak de Nederlandse industriepolitiek bleek af. Met spoorwegaanleg bemoeide de regering zich niet; deze werd overgelaten aan particulieren. In 1850 was de verhouding tussen Nederland en België in aantal aangelegde kilometers spoorlijn $1: 5$. En àls de overheid iets aan industriebevordering deed, bijvoorbeeld via de Nederlandsche Handelmaatschappij ten behoeve van de Twentse textielindustrie, droeg dat meer een filantropisch karakter: binnen deze NHM vond men dat de functie van industrie bestond uit werkverschaffing voor paupers en werklozen.

Tenslotte bestonden er verschillen in perceptie van het ondernemerschap. De mentaliteit van de Nederlandse entrepreneur kenmerkte zich volgens meerdere auteurs door een afkeer van risico en techniek, een voorkeur voor vrije tijd, door kortzichtigheid, gezapigheid en berusting. De opvatting dat apathie de hoofdoorzaak van de verlate industrialisering is geweest wordt, in verschillende mate van nuances, gedeeld door I.J Brugmans (1975, vooral pp. 66-71), H.F.J.M. van den Eerenbeemt (1965), P.J. Bouman (in: J. en A. Romein, 1955, dl. 3: 82-4), P.W. Klein (1966: 3-4) en W.J. Wieringa (1955: 8-11). In zijn oratie drukt Klein zich in niet mis te verstane woorden uit: "(.) de leiders van de industriële bedrijven uit deze periode treden ons tegemoet als tot de fatsoenlijke stand behorende, slome dikbuikige ambachtsbazen, wier aan een geestelijke vervetting lijdend brein hen verhinderde de sprong uit de traditionalistische bedrijfsvoering 
te wagen' (1966: 3). Ook Brugmans noemt de behoudzucht, gezapigheid en honkvastheid - het ontbreken van de kapitalistische geest - de belangrijkste reden warom de Nederlandse entrepreneurs de buitenlandse concurrentie niet aankonden. Hij wijst erop dat de angst om te investeren, die daarop volgde, de Nederlandse industriëlen in een neerwaartse spiraal van defaitisme trok. Risicodragend kapitaal ging bijna uitsluitend naar buitenlandse staatsleningen en naar het verwerven van land (zie ook: De Vroede, 1981: 12). ${ }^{29}$ Maar Brugmans wijst ook op ongunstige 'harde' factoren, zoals gebrekkige transportmiddelen, hoge brandstofaccijnzen en de belasting die op invoering van stoommachines werd geheven. Een belangrijk deel van de veranderingen na 1850 schrijt hij toe aan het wegvallen van enkele beperkende bepalingen (1975: 218).

Mokyr vindt apathie een te gemakkelijke verklaring. Het zijn eerder sociaal-economische omstandigheden die de mentaliteit van de Nederlandse entrepreneurs verklaren dan andersom. Weliswaar was door het tekortschietende onderwijssysteem het gebrek aan technische kennis schrijnend (vgl. Goudswaard, 1981), maar adequate scholing was ook in Engeland een probleem (wat niet door Landes wordt onderschreven). Het onderwijs aan lagere klassen was evenmin toegesneden op industrie (vgl. Wleringa, 1955: 10; Brugmans, 1975: 141 \& 169-72), maar ook hier kan men aandragen: dat gold ook voor Engeland. Toch, zegt Mokyr, werden inadequate scholingsmogelijkheden een 'bottle-neck' voor Nederland's industrialisering, zeker naarmate een (toegepaste) wetenschappelijke benadering steeds belangrijker werd in industriële ondernemingen. Ook stelt Mokyr dat de risico-aversie van de entrepreneurs (en ook hun voorkeur voor vrije tijd) tot een geringe mate van investeren leidde.

Al met al geeft Mokyr een aantal 'niet-economische' factoren toch meer gewicht dan zijn uitgangspunt - kapitaalaccumulatie als enige beweger toelaat. Zijn conclusie dat de verlate Nederlandse industrialisering uiteindelijk volledig is toe te schrijven aan het lage reïnvesteringscoëfficient, vat ik op als een polemische stelling. Immers, ook Mokyr, die vermoedelijk het laatste woord heeft willen spreken in het debat over "economische oorzaken' versus 'psychische factoren', heeft zich verplicht gezien aan beide verklaringscomplexen ruimte te geven.

In dit debat was J.G. van Dillen's oratie Onstandigheden en psychische foctoren in de economische geschiedenis van Nederland (1949/64) een belangrijk moment. Ook in latere artikelen (1.964; waarin de oratie uit 1949 is opgenomen) wijst hij op het belang van de 'omstandigheden', die voor een

29 Eerenbeent ziet de afzijdigheid van de haute finance jegens de nationale nijwerheid als een belangrijke factor die een vroege ontwikkeling heeft vertraagd (1965: 32). 
belangrijk deel de 'psychische factoren' hadden beinvloed. Er was zeker wel ondernemingsgeest in het vroeg-negentiende-eeuwse Nederland, maar deze werd gesmoord door de afwezigheid van eigen bodemertsen, de mercantilistische handelspolitiek van de omringende landen, de gebrekkige infrastructuur als gevolg van de bodemgesteldheid, waardoor aanleg van spoorwegen technisch en financieel moeilijk werd, de ruime arbeidsmarkt die niet tot mechanisering uitnodigde, het weinig bekwame en energieke arbeidsaanbod. Bovendien betekende de Franse tijd - toen Nederland bijna twee decennia was afgesloten van de zee - de nekslag voor de stapelmarkt, waardoor ook de trafieknijverheid voor een groot deel verdween. Genoemde omstandigheden hadden ook weer een negatieve weerslag op het kapitaalbezit en het bankwezen. De geest van behoudzucht en berusting die over de Nederlandse entrepreneurs kwam, was een gevolg van ongunstige omstandigheden: het trage economische herstel van Nederland in de negentiende eeuw was vooral te wijten aan de grote materiële moeilijkheden, die moesten worden overwonnen (1964: 53-79).

Hiertegen bracht W.J. Wieringa (1955) in dat de genoemde omstandigheden niet het fallen van de Nederlandse entrepreneurs konden verklaren. Ondernemers met een modern-kapitalistische instelling waren in staat al deze omstandigheden (en Wieringa voegt er nog een paar bij, zoals de accijnzen op brandstof en het gemaal) te overwinnen. Maar dezen bestonden in Nederland nauwelijks. Het land was voorbestemd een handelsnatie te zijn, vond men algemeen. De diepere oorzaak van de weerzin om te industrialisering lag in de maatschappelijke verstarring die in de achttiende eeuw was opgetreden. ${ }^{30}$ Dus toch weer 'psychische factoren"? Niet uitsluitend. Wieringa wijst erop dat de economische ontwikkeling van Nederland in de negentiende eeuw het resultaat is van een groot aantal met elkaar samenhangende 'economische en niet-economische factoren' en men kan niet uitmaken welke van de twee verklaringscomplexen de zwaarst wegende invloed heeft gehad.

Wieringa noemt voorts het gebrekkige technische en (bedrijfs)economische onderwijs en, evenals Van Dillen, de kwaliteit van de beschikbare arbeid, die uit een oogpunt van vakbekwaamheid, arbeidzaamheid en verstandelijke ontwikkeling beneden peil was. Toch - en dat bewijst dat de onstandigheden niet onoverkomelijk waren - nam de moderne nijverheid in de eerste helft van de eeuw een aanvang. Roentgen, Van Vlissingen,

30 Men herkent hier misschien Jan Romein's beroemde "wet van de remmende voorsprong. Toegepast op Nederland's verlate industrialisering juist doordat de Republiek in de zeventiende eeuw in de overzeese handel een voorsprong had genomen op de omringende landen was het land later niet in stat - noch zag men de noodzaak - nieuwe vormen van commerciele aktiviteiten, zoals moderne fabrieksindustrie, te ontplooien. (Zie ook Lammers, 1984, die Romein's dialektische wettegen het licht van de organisatiesociologie theeft gehouden.) 
Salomonson en Regout waren daar om Wieringa's gelijk kracht bij te zetten. Maar voor het gemiddelde type van de toenmalige ondernemer waren de omstandigheden blijkbaar een te grote hinderpaal om van de vroeg-in de modern-kapitalistische tijd over te stappen' (ibid., p. 12).

Brugmans sluit zich aan bij Wieringa. Op de vraag naar de verlate Nederlandse industrialisering schrijt hij in Paardenkracht en mensenmacht: "Het antwoord kan (..) slechts dit zijn, dat een samenwerking van economische omstandigheden en psychische factoren tot het vermelde resultaat heeft geleid' (1961: 213). Net als Van Dillen noemt hij de omstandigheid van de ontbrekende ertsen en steenkolen (dat laatste nagenoeg), waardoor de machinebouw zich pas latat kon ontwikkelen en men afhankelijk was van invoer uit Engeland. Ook noemt Brugmans de hoge brandstofaccijns, die pas in 1864 werd afgeschaft, de ongunstige bodemgesteldheid voor de ontwikkeling van een spoorwegennet en - wat Van Dillen niet noemde de brede natuurlijke waterwegen die infrastructurele vooruitgang remde.

Net als Wieringa wijst Brugmans op de behoudzuchtigheid en berusting van de Nederlandse ondernemers en noemt deze naar Hildebrand: de geest van Oom Stastok, 'de personificatie wan alles wat duf, middelmatig en zelfvoldaan was in de tijd van de trekschuit en diligence' (Zonneveld, 1980). Maar Brugmans stelt dat 'psychische factoren' nooit uit het luchtledige komen. Als oorzaken van de Hollandse mentaliteit noemt hij het (ook door Van Dillen genoemde) ontbreken van een adequaat bankwezen en kapitaalmarkt, de afwezigheid van vernieuwing en energie brengende buitenlanders en het vrijwel ontbreken van een middenklasse, zodat de eliten daarboven geen voedingsbodem en stimulans hadden. Dat Nederlandse fabrikanten hun - beperkte - kansen niet grepen, kan ook worden toegeschreven aan deze sociale immobiliteit, het inadequate onderwijs, de gerichtheid van het bankwezen op buitenlandse beleggingen en - nieuw argument - het nagenoeg ontbreken van de rechtsvorm van de naamloze vennootschap.

Tot dan was alleen de vraag gesteld welke factoren de stagnatie konden verklaren. Had deze op haar beurt ók consequenties voor de "omstandigheden' en 'psychische factoren'? Volgens J.H. van Stuijvenberg (1967) geeft Van Dillen zelf al voorbeelden van hoe het ontbreken van economische groei de mentaliteit van ondernemers en arbeiders negatief beinvloedde (vgl. Van Dillen, 1949: 21). Als de nijverheid reeds een eeuw exportmogelijkheden ziet alnemen, is het dan verwonderlijk dat de ondernemingsgeest een knauw krijgt? Hoe kan men van arbeiders bekwaamheid en energie verwachten als zij, door een stagnerend bedrijfsleven, al decennia door werkloosheid en pauperisme worden geteisterd? (Stuijvenberg, 1967: 200) Ook de 'omstandigheden" ondervonden de negatieve effecten van industriële stagnering. Kan men aanleg van spoorwegen verwachten als er onvoldoende vraag naar dit vervoersmiddel is? En pas 
toen de industrialisering goed op gang kwam, wist men ook het obstakel van het invoeren (en incidenteel delven) van delfstoffen te overwinnen.

Ook de psychische factoren en de omstandigheden onderling kan men volgens Van Stuijvenberg niet los wan elkaar zien. 'Of een bepaald feit als een, de economische expansie belemmerende omstandigheid optreedt, hangt er namelijk mede vanaf, of het als zodanig door de ondernemers wordt beleefd en aanvaard. Of dit laatste zal plaatsvinden, is mede psychisch bepaald' (ibid., p. 201). Omstandigheden zijn geen 'objectieve factoren', zoals Wieringa meent. Van Stuijvenberg constateert een wederkerige beinwloeding. Deze heeft een versterkende werking: er zijn weinig startkansen voor entrepreneurs en doordat er daarom niemand begint, komen er ook geen kansen. Slechts uitzonderlijk wilskrachtige enkelingen -Van den Eerenbeemt (1965) noemt weer Roentgen, Van Vlissingen, Salomonson en Regout - vormen de uitzonderingen, die, misschien, de neerwaartse spiraal omzetten in een opwaartse - als tenminste de 'omstandigheden' en de 'psychische factoren' bij de minder wilskrachtigen niet te belemmerend werken. Dat de genoemde enkelingen in het algemene beeld geen wijzigingen hebben kunnen brengen, kan misschien gelijkelijk op het conto van 'de economische omstandigheden' en de 'psychische factoren" worden geschreven.

In 1968 verscheen J.A. de Jonge's De industrialisatie in Nederland tussen 1850 en 1914. Fischer (1983: 17) spreekt van de 'grote doorbraak in de industrialisatie-discussie'. De Jonge heeft kracht gezocht in onderzoek van een grotere systematiek (zo behandelt hij de industrialisering per bedrijfstak) en in veelvuldig gebruik van kwantitatief bronnenmateriaal en statistische bewerking daarvan. Hij heeft ook de economische ontwikkeling in andere sectoren onderzocht en de samenhang met bevolkingsgroei, welvaart, opleiding, beroepsstructuur en overheidspolitiek. Het is jammer dat De Jonge 1850 als vertrekpunt heeft genomen, zodat zijn licht niet schijnt over de beginjaren van de Nederlandse industrialisering. Dat hebben onderzoekers na hem wèl gedaan. Met name de oorzaken van de achterstand De Jonge had meer aandacht voor het verloop - kregen na 1968 weer meer nadruk. Naast de vergelijkende studie gebaseerd op loonkostenverschillen van Mokyr verschenen studies van R.W.J.M. Bos (1979) en R.T. Griffiths (1979). Beiden zochten eveneens naar verklaringen door analyse van factorkosten, maar dan van alle factorkosten (Fischer, 1983: 20), die bovendien werden gedifferentieerd naar bedrijfstak en regio. Hun bevinding: de oorzaken van Nederlands achterstand kunnen niet worden gegeven, want: 'Het uitblijven van mechanisatie in twee verschillende regio's kan per regio verschillende oorzaken hebben' (ibid., p. 19). Hetzelfde geldt voor bedrijfstakken. Fischer: 'Dit zou tevens een verklaring kunnen zijn voor de dikwijls van elkaar afwijkende en soms zelfs tegenstrijdige verklaringsgronden die door de verschillende auteurs naar voren zijn gebracht om 
het uitblijven of relatief achterblijven van de mechanisatie in Nederland te verklaren" (ibid, p. 19).

In een latere publikatie stelt Griffiths (1980) dat er van een Nederlandse achterstand helemaal geen sprake is geweest. Hij wordt daarin bijgevallen door J.J.M. de Meere (1982), Camijn (1987) en Van Zanden, die van een 'mythe' spreekt (1989). Zij menen dat de periode $1825-1850$ te somber is afgeschilderd. Betrekt men de niet-industriële sectoren in het beeld, dan overtrof het gemiddelde groeipercentage van de produktie de procentuele bevolkingsgroei. De inkomensontwikkeling per hoofd van de bevolking is ook een interessante indicator: de jaarlijkse stijgingspercentages van de perioden 1802-1850 en 1850-1909 ontlopen elkaar nauwelijks: 1,04\% en $1,08 \%$. De conclusies van deze studies laten echter onverlet dat het fabriekssysteem in Nederland vóór 1850 nog maar sporadisch ingang had gevonden.

In de eerste helft van de negentiende eeuw streefde België Nederland voorbij - ondanks de crisis in Vlaanderen in de jaren veertig, ondanks de verbeterde handelsvoorwaarden waarvan de Nederlandse landbouw kon profiteren, ondanks de toenemende opbrengsten van koloniale exploitatie, die de maritieme economie in leven hield. De glorie en rijkdom van handel en zeevaart verbleekte in een wereld die meer en meer toebehoorde aan de labriek en de spoorweg, schrijft Mokyr (1976: 261).

Ook over aanvang en voltooiing van de Nederlandse inhaalmanoeuvre is geredetwist. Brugmans noemt de periode van 1850 tot 1870 een overgangsperiode tussen het vroeg- en modern-kapitalistisch tijdperk (1975: 214). De stagnatie maakte plaats voor groei; de ondernemingsgeest ontwaakte. Het fabriekssysteem werd de overheersende organisatievorm (Brugmans, 1961: 201). Fabrieksstaten uit 1857 tonen aan dat naast de bovengenoemde bedrijfstakken waar vóór 1850 het grootbedrijf zijn intrede had gedaan, nu ook, onder meer, verschillende steenbakkerijen, metaalbedrijven, glasblazerijen, wagenmakerijen en lettergieterijen meer dan 40 arbeiders in dienst hadden (Brugmans, 1975: 39). Ook veranderingen in de samenstelling van de beroepsbevolking wijzen in de richting van toenemende industrialisering.

Dat conjunctuurgolven zich tot 1870 in Nederland slechts in verzwakte vorm deden gevoelen, beschouwt Brugmans als een bewijs dat het moderne kapitalisme hier nog niet tot een overheersende positie was gekomen. Pas rond 1870 begint volgens Brugmans in Nederland de echte industriële bloei.

De Duitser E. Baasch spreekt van het begin van een 'wirtschaftliche Neugeburt' rond 1850, die zich langzaam maar gestadig heeft doorgezet (1927: 590). Ook Verberne situeert de start van de overgangsfase rond de eeuwhelft: "Omstreeks 1870 kan de wijziging ongeveer voltooid heten, al 
was nog zo weinig beslist" (1959: 12). Maar eerder schrifft hij dat de industriële bloei pas aan het eind van de eeuw kan worden herkend (1938: 122). Anderen situeren de start van de inhalmanoeuvre minstens twintig jaar later. Van Dillen wijst erop dat Nederland slechts in geringe mate wist te profiteren van de gunstige internationale conjunctuur tussen 1849 en 1873, die weer was omgeslagen toen de voorwaarden in Nederland voor een nieuwe economische expansie eindelijk waren vervuld. 'De grote opleving kwam pas, toen omstreeks 1895 de internationale economische omstandigheden snel verbeterden' (1949/1964: 22). Van Dillens 'grote opleving' heet bij Wieringa 'versnelling in de ontwikkeling', maar hij is het met de eerste eens: al was de mechanisatie op gang gekomen en begon het fabriekssysteem opgang te maken, terecht is het Nederland van $\mathbb{1 8 7 0}$ een onderontwikkeld gebied genoemd. En de decennia daarna verliep de ontwikkeling slechts zeer geleidelijk. Pas tegen het eind van de eeuw trad de genoemde versnelling op. De Jonge situeert de 'versnelling in de groei' tussen 1890 en 1910. Het voorafgaande decennium is een overgangsfase. De nijverheid had wel al aan veelzijdigheid gewonnen door toepassing van nieuwe procédés, maar de groei werd te zeer geremd door de wereldwijde economische depressie. Pas na 1890 wordt de groei dynamisch ${ }^{3 !}$ en krijgt de ontwikkeling door de verspreiding van nieuwe technieken over een aantal bedrijfstakken een veelzijdig karakter. Wat de versnelling heeft aangedreven, zijn de toepassing van nieuwe produktietechnieken, de expansie van de buitenlandse afzet, de vergroting van de inkomsten uit de koloniën en de bloei van de scheepvaartsector en niet zozeer uitbreiding van het bankwezen en de beroepsbevolking.

In een tijdtabel kan de Nederlandse industrialisering als volgt worden samengevat:

$1815-1825$

$1825-1850$

stagnatie of slechts geringe groei

stijging van de produktie in de belangrijkste nijverheidscategorieën, die evenwel niet is toe te schrijven aan ingrijpende veranderingen in de toepassing van nieuwe technieken of organisatievormen

1850-1870 nog geen grootschalige toepassing van mechanisatie en stoomkracht, maar wel tekenen van groeiende bereidheid daartoe, gepaard gaand met daadwerkelijke initiatieven: een overgangstijdperk

$31 \mathrm{Vgl}$. de personeelsbezetting in het midden- en grootbedriff in procenten van de totale beroepsbevolking in de nijverheid: in 1859 was dat 20,0 procent; in 1899 23,5 en in 190944,5 . Het grootbedriff nam het grootste deel van deze stijging voor haar rekening: van 15 procent in 1899 tot 29 in 1909 (De Jonge, 1968: 232) 

daadwerkelijk tot mechanisatie komen, maar door dalende conjunctuur vooralsnog weinig effectief

Ook voor de stad Maastricht betekende de Industriële Revolutie zowel een technische verandering - de introductie van stoommachines, bijvoorbeeld, die slijpstoelen, luchtpompen, kleipersen, mengkuipen, enzovoort gingen aandrijwen - als een diepgaande sociale en economische verandering die bestaande markt-, machts- en identiteitsverhoudingen fundamenteel wijzigde. ${ }^{32}$

Hierboven is gekozen voor het begrip Industriële Revolutie om het unieke karakter van de Westeuropese industrialisering te accentueren. Daarin zijn echter nationale verschillen geconstateerd: tussen Engeland en het continent en tussen continentale landen onderling, België en Nederland in het bijzonder. Op lagere aggregatieniveaus - regionale, lokale, sectorale - kumnen eveneens verschillen worden geconstateerd. De Industriële Revolutie in Maastricht - als stad in het uiterste zuiden van Nederland, waar de industrialisering voornamelijk ingang vond in de glas-, kristal- en aardewerkproduktie - is, in die combinatie, uniek. Maar de uniciteit van de vroege Maastrichtse industrialisering, en het werven, behouden en beheersing van arbeid als aspect daarvan, is slechts relatief. De Maastrichtse Industriele Revolutie draagt zowel kenmerken van de internationale als nationale als sector-specifieke Industriële Revolutie.

Aan het einde van de achttiende eeuw kenmerkte Maastricht zich niet in de eerste plaats door markt- en produktie-aktiviteiten (handel noch nijverheid voerden er de boventoon ${ }^{33}$, , maar eerder als machtscentrum: als vestingstad en militair garnizoen en als kerkelijk, bestuurlijk en juridisch centrum. Het militaire belang van de stad was begonnen na de

32 Terwijl de associatie met gewelddadige omwenteling ook nog wel werd (en wordt) gemaakt: een deel der Maastrichtenaren zagen (en zien) de fabrieken, ofwel de Regouts, als verstoorders van een betrekkelijk harmonieuze stedelijke gemeenschap.

33 Maastrichtse handelsaktiviteiten bleven voornamelijk beperkt tot doorvoer van en naar Holland aan de ene kant en het Luikse en Akense aan de andere kant (Maenen, 1959: 1). Door de verzorgende functie van de stad ten opzichte van het omringende (en tamelijk autarke) platteland was er 'een vrij omvangrijke groep wan trafiekanten, neringdoenden en ambachtslieden' ter stede gegroeid, die zich nochtans geconfronteerd zag met een beperkte en constante vraag (ibid.). 
verovering door Frederik Hendrik en duurde tot 1867 , waama de vestingwerken bijna volledig werden ontmanteld. Een belangrijk deel van de bevolking was werkzaam in het onderhoud en herstel van de vesting of in de dienstverlening ten behoeve van het garnizoen: voeding, kleding, schoeisel, amusement, prostitutie (Thewissen, 1940). Maestricht est plutôt une place d'armes qu'une ville de commerce, constateerde A. Ricard in 1800 in zijn Traité général du commerce an VII, II.

In de tweede helft van de achttiende eeuw deden zich twee ontwikkelingen voor die Maastricht, commercieel gezien, tot een nog stillere stad maakten: een ontluikende plattelandsnijverheid in de regio en de aanleg van een aantal nieuwe wegen die Maastricht links en rechts lieten liggen. $\mathrm{Na}$ de inval van de Franse troepen in $1795 \mathrm{kwam}$ er enige verbetering in de economische positie van de stad (Van Doorn, 1947: 6, maar Maenen is het daarmee niet eens, 1959: 3). Evenals in het latere België kreeg de Maastrichtse handel en nijverheid toegang tot de Franse markt. Dankzij de opbloei van het economisch verkeer ontwikkelde zich in de stad een aanzienlijke doorvoerhandel. Ook beleefden een aantal industrieën van consumptie-artikelen, zoals brouwerijen en branderijen, een bescheiden bloei.

Met de terugtrekking van de Fransen ging het pas verworven achterland weer verloren. Tussen het Koninkrijk der Nederlanden en Frankrijk verschenen tollinies (daarbij moet worden bedacht dat de tollinie tussen Nederland en Pruisen ook benauwend dicht bij Maastricht liep.) Hierdoor daalden de afzetmogelijkheden van consumptie-artikelen met 25 tot 50 procent. De eerstkomende twee decennia leidden handel en nijverheid in Maastricht een kwijnend bestaan. Zo hadden de suikerraffinaderijen in 1829 nog slechts tien personem in dienst.

Waren in 1816 nog 1275 personen werkzaam in de nijverheid, in 1829 slechts 400 . Detailhandel en ambachtelijke nijverheid moesten de stedelijke economie in de jaren twintig dragen. Het was in de dienstensector waar de bevolkingsaanwas ${ }^{34}$ werk vond, ook al omdat deze sector werd gestimuleerd door het infrastructurele beleid van Koning Willem I. Velen waren actief in openbare werken, zoals de aanleg van de Zuid-Willemsvaart in 1826. Een jaar daarvoor was er een weg naar Aken gereedgekomen, in 1829 gevolgd door éen naar Verviers. Wat aan het eind van de achttiende eeuw achterwege was gebleven, gebeurde in de jaren twintig van de negentiende wèl: Maastricht kreeg een verbeterde aansluiting op de buitenwereld. Lang zou dat echter niet duren.

$\mathrm{Na}$ het uitbreken van de Belgische Opstand in 1830 verslechterde de

34 Voor Nederland geldt dat de bevolking vanaf de helft van de zeventiende eeuw stagneerde en dat deze stagnatie pas tegen het einde van de achttiende eeuw overging in een lichte groel (Faber, 1977). 
economische siluatie van de stad verder. Na de Franse tijd was Maastricht al tot de armste steden van Nederland gaan behoren - vergelijkbaar met Rotterdam, Amsterdam en Leiden, waar extreem hoge bedelingspercentages werden gescoord - maar na 1830 werd dat nog erger. In één gechargeerde zin: de gegoede burgerij trok weg, de middenstand verarmde en het volk verpauperde verder.

De zuidelijke separatisten hadden ook onder de Maastrichtse elites aanhangers. Toch stond de hogere burgerij als geheel minstens ambivalent tegenover een scheiding van de Noordelijke Nederlanden. Op culturele gronden waren ze waarschijnlijk in meerderheid vór de rebellerende provincies ${ }^{35}$, maar een afscheiding van het Koninkrijk zou voor de lokale doorvoerhandel - de economische belofte voor de stad - de doodssteek betekenen. Men kan stellen dat door de Zuid-Willemsvaart deelneming aan de Opstand economisch onaantrekkelijk was.

Doordat de Opstand wèl aansloeg in de andere Limburgse steden, raakte Maastricht alsnog in het gevreesde isolement. ${ }^{36}$ Dit verklaart in belangrijke mate de leegloop in de jaren 1830 en '31 - toen een deel van de hogere burgerij en een aantal hogere militairen naar het afgescheiden Zuiden vertrok. Toen in 1839 de scheiding met België een officieel staatkundig feit was, trokken ook mensen uit de lagere strata weg.

Dat Maastricht - en daarmee later heel Limburg - bij Nederland bleef en miet hoofdstad van de Belgische provincie Limburg werd, kan de consequentie van het nastreven van een militair belang worden genoemd: generaal Dibbets had de opdracht gekregen de stad voor het Koninkrijk te bewaren en moet dat met straffe hand hebben gedaan. Zowel in economisch als sociaal-cultureel opzicht was Maastricht sterk op het Zuiden georiënteerd (zie voor de culturele oriëntatie: Orbons \& Spronck, 1966; Spiertz, 1966). De Maastrichtse midden- en bovenlagen spraken Frans; lokale kranten waren franstalig; de intellectuele subcultuur was sterk gericht op de ideologie van de Franse Revolutie.

De Jonge stelt dat de bijdrage van de buitengewesten aan de economische groei van Nederland gering is geweest omdat tussen de centrale en de perifere provincies tot halverwege de negentiende eeuw nog nawwelijks kan worden gesproken van economische integratie. Als belangrijkste oorzaak ziet hij het gebrekkige transportsysteem, waardoor grote prijsverschillen voor grondstoffen en eerste levensbehoeften bleven bestaan tussen

35 De anecdote dat het Mastrichtse revolutionaire comité op het moment dat in Brussel de opstand uitbrak, dromken in een cafe zat en daardoor niet alert kon reageren, is te aardig om onvermeld te laten.

36 Zo werd de Zuid-Willemsvaart een paar kilometer ten Noorden van de stad op opstandig gebied met de Maas verbonden, waardoor de overslagaktiviteiten elders plaatsvonden. 
gebieden die niet ver van elkaar lagen (1971: 215). De zuidwaartse economische oriëntatie van Maastricht laat zich in dit licht beter begrijpen.

Méér nog dan de Engelse industriële pioniers vór hem genoot Petrus Regout het voordeel dat hij ongehinderd door gildenrestricties geschoolde arbeiders kon werven. Formeel werden de gilden in 1798 door de Fransen opgeheven, in de praktijk bleven ze nog twintig jaar werkzaam, totdat ze in 1818 definitief verdwenen (Brugmans, 1961: 3-5). De vrijheid van beroepsuitoefening bevorderde de arbeidsmobiliteit aanmerkelijk en daarvan profiteerden de Noord-en Zuidnederlandse industriële entrepreneurs gelijkelijk.

Andere Engelse factorvoordelen golden niet voor Maastricht en Regout. Toegankelijkheid tot de zee en daarmee verre markten was, dankzij de Zuid-Willemsvaart, nog wel van toepassing, en ook betekenden de nieuwe wegen naar Aken en Verviers een belangrijke infrastructurele verbetering, maar men kan niet zeggen dat Maastricht langdurig van oorlogen was gevrijwaard, dat de kennis en bekwaamheden van arbeiders ter stede hoog was - denk aan Regout's inspanningen dure buitenlandse vakkrachten naar Maastricht aan te trekken -, dat er technisch onderwijs kon worden gevolgd, dat er bij de Nederlandse banken bereidheid bestond tot kredietverstrekking aan de industrie, dat de stad opviel door een commerciële en industrieel-technische ${ }^{37}$ ondernemingszin of door een traditioneel lage onzekerheidsvermijding en hoge mate van individualisme. Binnen de stadsmuren heerste eerder de macht der gewoonte, een 'geringe zin voor initiatief' en een 'geringere waarde, die men aan tijd en geld hecht' (Van Doorn, 1947: 4). Dezelfde auteur spreekt van het 'weinig rationeel-economisch georiënteerde Maastricht" (ibid., p. 84). En het zelfversterkend effect van de industrie in de stad was in de eerste decennia na Regout's start vanzelfsprekend gering.

Aan de vraagzijde kon ook Regout inspelen op de groeiende behoeften vam een groeiende binnenlandse en vooral buitenlandse populatie. Zijn eenvoudige glazen en aardewerken artikelen vonden moeiteloos ingang zowel in het eigen land (inclusief koloniën) als op de steeds toegankelijker wordende buitenlandse markten.

Maar kan men niet stellen dat traditionele restricties geen belangrijke rol speelden: de tollinies rondom de provincie Limburg zijn genoemd - en al waren ze deels nieuw, het waren traditionele belemmeringen van het vrije economische verkeer.

In zijn financieel management, dat beperkt werd door geringe kredietmogelijkheden, volgde Regout de Engelse lijn: hij wendde zijn winsten voornamelijk aan in investeringen en ging pas na 1850, toen hij zijn 'slag' had geslagen, statuskapitaal accumuleren: de woonhwizen aan de Bosch- 
straat, de buitenhuizen in de gemeente Meerssen.

Landes heeft geconstateerd dat Franse en Duitse entrepreneurs op het punt van industriepolitiek gunstiger af waren dan de Engelse fabrikanten. In de Nederlanden heeft, zoals beschreven, koning Willem I een actief beleid gevoerd. De kredieten en orders waarmee hij Regout heeft begunstigd passen daarin, maar hebben op het welslagen van Regout's ondernemingen geen grote invloed gehad. ${ }^{38}$ Nederland heeft zich niet tot een centralistische staat ontwikkeld en de economische politiek is niet dirigistisch, maar ondersteunend geweest (Van Iterson \& Olie, 1992). Zo ook Willem I's industriepolitiek: het accent lag op verbetering van de infrastructuur en andere condities. De koninklijke steun aan Regout was symbolisch, niet structureel.

De hoog ontwikkelde infrastructuur en het ontbreken van grote landschappelijke obstakels (Holland's brede riviermondingen uitgezonderd) hadden een dempend effect op de transportkosten. Daar $\mathrm{kwam}$ nog bij dat de Nederlanden vijf tot zeven maal zo klein waren als Duitsland en Frankrijk, waardoor ook de markten in de Lage Landen niet dermate gefragmenteerd waren (geisoleerde rurale streken kende het Koninkrijk nauwelijks). Maastricht - in het huidige Nederland een perifere stad, maar in het verenigd koninkrijk betrekkelijk centraal - zag de infrastructurele winst uit de jaren twintig (waterweg, straatwegen) echter snel te niet gaan: de Belgische Opstand betekende dat voor enkele decemnia een hoog politiek obstakel werd opgeworpen. Het is een klein wonder dat Regout juist in deze periode, de jaren dertig en veertig, ondanks hogere transportkosten, verminderde afzetmogelijkheden en felle, ideologisch gekleurde concurrentie zijn industriële loopbaan wist op te bouwen.

Dit krijgt nog meer reliëf als men bedenkt dat ook in Maastricht, dat staatkundig bij Nederland bleef, industriële aktiviteiten laag in aanzien stonden. De stedelijke elites en middenklassen lieten zich aanvankelijk nauwelijks ermee in. Aan overheidsfuncties en gevestigde beroepen werd de voorkeur gegeven. Regout, een man zonder opleiding ${ }^{39}$ en die als pausgezinde enige religieuze discriminatie ondervond ${ }^{40}$, werd gezien als een parvenu. Het kostte hem veel uithoudingsvermogen zijn fabrieksterrein te vergroten, huizen en gebouwen te kopen of te bouwen - op alle

38. De kredietverlening die de oprichting van Regout's kristal- en glasblazerij 'mede mogelijk' (Maenen, 1959: 111) maakte, misschien uitgezonderd.

39 Door de dood van zijn vader was hij immers op 13-jarige leeftijd van school gehaald om in de zaak mee te heipen.

40 Denk aan het anti-clericale gezindheid van de liberale eliten, waarvan de dichter-advocaat Théodore Weustenraad met zijn dialektepos 'De Persessie van Sjèrrepenheuvel' een briljant staaltje heeft laten zien. 
mogelijke manieren zat de stedelijke overheid deze overdreven roomse nowtou riche dwars: met weigeringen, voorschriften en andere bureaucratische treiteringen.

Aan de andere kant is het te begrijpen dat Regout's grote ambitie, in combinatie met de typisch "continentale" opvating van industrieel ondernemen (een gesloten familie-imperium opbouwen, om veel geld te verdienen, maar méér nog als doel in zich), weerstanden opriep. De aversie tegen dit individualistisch streven ten behoeve van het eigen kleine bloedcollectief was des te groter omdat een belangrijk deel van het stadsoppervlak en het stadsvolk erin werd betrokken.

In tegenstelling tot veel continentale entrepreneurs had Regout er weer geen moeite mee technieken en produkten als iets onpersoonlijks te zien, kwaliteit op te offeren voor kwantiteit en traditionele gereedschappen en methoden terzijde te schuiven als efficiëntere beschikbaar kwamen. Regout's lage onzekerheidsvermijding moet velen in Maastricht een affront zijn geweest. Zijn speculerende mentaliteit werd ongetwijfeld ook gezien als een bewijs van slechte smaak. Zijn snel vergaarde rijkdom werd als immoreel beschouwd: het kon niet anders of het was ten koste van anderen gegaan.

Regout behoorde tot de groep continentale pioniers die, geholpen door Engelse experts, getalenteerd, wilskrachtig en bekwaam genoeg waren de drijvende kracht te vormen van het wegwerken van de achterstand op Engeland, vergroot tijdens de Franse Revolutie, die verlies van arbeid en kapitaal, inflatie en politieke instabiliteit had gebracht. Een groep nieuwkomers die, betrekkelijk los van elkaar, opereerden; die niet bang waren te mislukken; die niet werden ontmoedigd maar uitgedaagd; die de institutionele en economische veranderingen na 1815 wisten uit te buiten; die niet alleen streefden naar imitatie, maar naar verbetering van Engelse produkten en methoden.

In Regout's initiatieven kan men zowel 'Engelse' als 'continentale' trekken herkennen. Op de dimensie 'Belgisch'-'Nederlands' moet hij meer aan de Belgische kant worden geplaatst.

De geest van zelfingenomen behoudzucht die de Noord-Nederlandse (potentiële) ondernemers ervan weerhield industriële aktiviteiten te ontplooien, kon men in Maastricht niet vinden. De 'psychische factoren' in de geisoleerde vesting waren nóg ongunstiger. In plaats van tevredenheid heerste er een malaise. 'De omstandigheden' van de vroege jaren dertig zaten ook niet mee: een militaire blokkade, een politiek-staatkundig en economisch isolement, een sociale drainage als gevolg van leegloop en overloop, enzovoort. De 'omstandigheden' waren in dit geval het eerst, maar de 'psychische factoren' die weldra zichtbaar werden hebben op hun beurt de Maastrichtse omstandigheden weer negatief beinvloed: pas in de jaren vijftig, ruim een decennium na de definitieve afscheidingsregeling, 
kwamen andere industriëlen op het toneel ${ }^{41}$ - en dan nog voornamelijk op buitenlands initiatief, zoals nog zal worden beschreven. Men kan stellen dat zowel de (economische) omstandigheden als de psychische factoren (met wederkerig, versterkend effect, zoals Van Stuijvenberg het voor de Nederlandse industrialisering zag) een rem waren op de opkomst van de industrie in Maastricht, die in de naburige steden Luik en Verviers al enkele decennia eerder met succes had plaatsgevonden. Petrus Regout was niet zozeer een voorloper, maar zijn navolgers waren achterlopers.

Al stonden zijn fabrieken op Nederlandse bodem, als men kijkt naar het tijdstip van industrialisering en als men de economische en sociaalculturele orientatie van de stad op het Zuiden in overweging neemt, moet hij worden gerangschikt tot het Belgische (i.c. Waalse) patroon. Ook als men kijkt naar oorspronkelijke factorvoordelen als aanwezigheid, beschikbaarheid en kosten van grondstoffen, energie en arbeid, onderscheidde Maastricht zich niet bijzonder van Belgische steden als Luik, Verviers, Charleroi of Gent. Weliswaar waren grondstoffen noch energie in de direkte omgeving van de vesting aanwezig ${ }^{42}$, maar via waterwegen (de Maas $^{43}$ en, vanaf de jaren vijftig, het kanaal naar Luik) en, later, via spoorwegen wèl eenvoudig beschikbaar - en, gelet op de afstand tot de vindplaatsen, betrekkelijk goedkoop. Ook als men kijkt naar de expeditie van gerede produkten was Maastricht in mornale omstandigheden (d.w.z. vóór 1830 en na 1839) niet ongunstiger gelegen dan genoemde steden.

Op de aanwezigheid, beschikbaarheid en kosten van arbeid ter plaatse zal worden teruggekomen. Hier zij vast vermeld dat ongeschoolde arbeid ampel aanwezig en beschikbaar ${ }^{44}$ was, tegen een lage prijs, maar dat voor geschoolde arbeid in alle opzichten het omgekeerde gold. In tegenstelling tot in Luik, Namen, Henegouwen en Oost-Vlaanderen kon in Maastricht niet worden geprofiteerd van de kennis en vaardigheden van arbeiders uit de proto-industrie. ${ }^{45}$ Vooral in de beginjaren van de fabrieken, toen de leereffecten - een andere begunstigende factor - nog be-

41 Het is opvallend dat leden van de elites uit afkeer van de industrialisering van de stad juist uit Maastricht wegtrokken (Bos, 1986: 80).

42 Steenkolen zouden in het Limburgse pas decennia later op grote schaal worden gedolven.

43 Slechts voor de helft van het jaar bevaribaar.

44 Inzetbaar is een ander verhaal.

45 Uit een melding uit 1828 blijkt dat het enige voorbeeld van een bestatande proto-aandewerkindustrie in Maastricht de fabriek van Marchal in Wyck was, met elf werklieden. "Van het voorkomen van huisindustrie in Maastricht is na 1830 geen spoor meer te vinden' (Maenen, 1959: 285). 
scheiden waren, kon Maastricht worden beschouwd als een ongunstige vestigingsplaats met betrekking tot de produktiefactor arbeid. Daar staat tegenover dat ook Vervierse fabrikanten, zoals al is geconstateerd, problemen hadden geschoolde arbeiders te behouden. Met hun grotere mobiliteit had elke fabrikant rekening te houden. Als vestigingsplaats voor industriele massaproduktie lijkt Maastricht ongeveer even gunstig als een stad als Gent.

Zo bezien vormen de fabrieken van Regout geen uitzondering op het patroon van de verlate industrialisering van Nederland, maar ze waren 'normale' 'Belgische' bedrijven, die echter door politiek-militaire omstandigheden grote moeilijkheden moesten zien te overwinnen. Het zijn deze bijzondere omstandigheden die reliëf geven aan Regout's ondernemersm kwaliteiten - méér nog dan het feit dat hij in de jaren vijftig en zestig het grootste fabriekscomplex (gemeten naar aantal werknemers) van Nederland bestierde.

Over Josiah Wedgwrood schreef de Amerikaan Sidney Pollard in The Genesis of Modern Management (1965):

It was above all the genius of Josiah Wedgwood which transformed a provincial backwater into one of the leading growth points of the industrial revolution.'

Al kan men niet zeggen dat Petrus Regout van de middelgrote garnizoensplaats Maastricht een speerpunt van de Nederlandse industrialisering heeft kunnen maken (al was het maar omdat de stad in het verkleinde koninkrijk te perifeer was komen te liggen), een getalenteerd ondernemer moet Regout worden genoemd. Maar hier moet worden gedifferentieerd naar aktiviteiten. In strategisch opzicht betoonde Regout zich een risiconemer, alert op de mogelijkheden die nieuwe markten en technieken boden. Vooral in de eerste decennia, toen Regout woor een belangrijk deel ook nog handelsaktiviteiten ontplooide, leek hij een ideaaltypische representant van het piratenkapitalisme (Thorstein Veblen's piracy capitalism, 1978/1904). ${ }^{46}$ Kijkt men naar de interne organisatie - de structuur, cultuur en beheersing van produktie-aktiviteiten - dan vallen Regout's behoudzucht en onzekerheidsvermijding op. Deze tweeslachtigheid is niet willekeurig. Ook kapitalisten beseften dat het kapitalisme het

46. In de woorden van D.C. van de Poel: '[.] In eerste analeg was dit type (het "nieuw type ondernemers", avi) reeds in de vroeg kapitalistische periode gevornd, zakelijk, rationeel calculerend en concurrerend mar daarbij in we overzeehandel toch ook niet ontgroeid aan het avontuurlijke, dat met de winsten uit het handelskapitalisme vaak nog zo nauw verbonden was' (1953: 149). 
beste gedijt in een rustig, stabiel klimaat - zowel het externe klimaat van de institutionele omgeving als het interne klimaat van de arbeidsverhoudingen in de organisatie. Daarnaast was de produktiefactor arbeid in zijn aard nu eenmaal minder flexibel: mensen plooien zich minder gemakkelijk dan geld en goederen. De perceptie van deze produktiefactor door de fabrikanten zelf leed onder eenzelfde inflexibiliteit: denkbeelden omtrent arbeiders kenmerkten zich door conservatisme. Het is deze tweeslachtigheid - reëel of imaginair - die meer dan wat ook de fabrikanten tot legitimering van hun gedachten en daden heeft genood (zie hoofdstuk 5).

Hierboven is gesteld dat de entrepreneur Petrus Regout in het Belgische (preciezer Waalse) patroon paste. Dat geldt voor zijn organisatie evenzeer als voor zijn persoon. Omdat het onderzoek naar organisatieculturen van Hofstede cs (1991, deel 3) zich vooralsnog niet tot Belgische bedrijven heeft uitgestrekt, is het zinwoller Regout's aktiviteiten alleen te bezien in termen van nationale-cultuurdimensies, waarop de plaats van België (uitgesplitst naar Vlaanderen en Wallonië) wèl is uitgerekend. ${ }^{47}$ Van de vier dimensies die Hofstede uit zijn onderzoek in circa 50 IBM-vestigingen heeft gedestilleerd - machtsafstand, onzekerheidsvermijding, masculiniteit versus femininiteit, individualisme versus collectivisme (woor een gedetailleerde verklaring: Hofstede, 1991: 23-138; i.h.b. 23-28, 50-54, 79-85 en 109114) zijn hier vooral de eerste drie van belang.

Omdat de 'Belg'/ Waal' Regout opereerde in een Nederlandse institutionele omgeving en voor een bellangrijk deel op Nederlandse markten, is het interessant de Belgische en Nederlandse scores in Hofstede's IBM onderzoek naast elkaar te leggen. Omdat de Industriële Revolutie in heel West-Europa is geschetst, zullen ook de Engelse, Franse en Duitse scores in het beeld worden betrokken.

${ }^{47}$ Mijn speculatie is dat men in Regout's bedrijven over de gehele linie eerder proces-georiënteerd dan resultaat-georiënteerd (Hofstede's organisatiecultuurdimensie 1) is geweest; eerder werk-georiënteerd dan mens-georiënteerd (dimensie 2); eerder organisatiegebonden dan professioneel (dimensie 3); eerder een gesloten dan een open systeem heeft gevormd (dimensie 4); eerder een strakke dan een losse beheersing heeft gekend (dimensie 5) en eerder normatief dan praklisch georiënteerd is geweest (dimensie 6) (Voor een verduidelijking van deze dimensies: opnieuw Hofstede, 1991: 189-192). 


\begin{tabular}{lcccc}
\hline & PDI & UAI & MAS & IDV \\
\hline Wallonië & 67 & 93 & 60 & 72 \\
Vlaanderen & 61 & 97 & 43 & 78 \\
België totaal & 65 & 94 & 54 & 75 \\
Nederland & 38 & 53 & 14 & 80 \\
Groot-Brittanië & 35 & 35 & 66 & 89 \\
Frankrijk & 68 & 86 & 43 & 71 \\
West-)Duitsland & 35 & 65 & 66 & 67 \\
Wallonië minus & & & & \\
Nederland & 29 & 40 & 46 & -8 \\
Belgie minus & & & & \\
Nederland & 27 & 41 & 40 & -5 \\
\hline
\end{tabular}

(Bron: Hofstede, 1980: 337, 1991: 26, 113,84,53)

De dimensie individualisme vs collectivisme (IDV) is de enige waarop alle vijf landen hoog scoren (zij behoren tot de hoogst scorende 15 van de hele populatie). Bij internationale confrontaties tussen deze landen zullen op dat wlak weinig problemen ontstaan. Industriële entrepreneurs zullen in meerderheid de opvatting onderschrijven dat van elk mens mag worden verwacht (en daarom gerespecteerd) dat deze in eerste instantie voor zichzelf en zijn naaste verwanten zorgt. Hierin zullen ze instemming en weerklank vinden bij de meerderheid van de leden van alle vijf naties.

Op de dimensie machtsafstand (PDI) (groot versus klein) zijn er opmerkelijke verschillen tussen enerzijds Groot-Brittanië, Duitsland en Nederland (alledrie tamelijk laag/klein; rond de 35) en anderzijds Frankrijk en België (alletwee tamelijk hoog/groot; rond de 65). De meeste Belgische en Franse fabrikanten zullen hun verhouding tot hun ondergeschikten zien als één van fundamentele ongelijkheid ('existentially unequal', ibid., p. 35; zie ook: d'Tribarne, 1989 over de verschillen tussen een Frans, Nederlands en Amerikaans produktiebedrijf van één multinational), terwijl de meeste Engelse, Duitse en Nederlandse fabrikanten eerder geneigd zijn te denken dat ongelijkheden zouden moeten worden geminimaliseerd welke egalitaire waarde ook door Engelse, Duitse en Nederlandse arbeiders grotendeels wordt onderschreven. Een 'Waalse' werkgever als Regout kan daarom gezags- en loyaliteitsproblemen verwachten met zijn arbeiders - ware het niet dat ook de Maastrichtse arbeiders als 'Belgisch' of 'Waals' moeten worden bestempeld. Ik verwijs hier naar de staatkundige weder- 
waardigheden van de stad ${ }^{48}$ plus het feit dat Maastricht, evenals de overgrote meerderheid van de Franse en Belgische bevolking, katholiek is (geweest) - niet de enige katholieke stad in Nederland, well de enige katholieke stad met deze staatkundige eigenaardigheden en daarmee samenhangende sociale, economische en culturele oriëntatie op de Latijnse (i.c. Waalse) wereld.

Anders was het gesteld met belanghebbenden uit de omgeving van Regout's fabrieken. Het sterk hiërarchische karakter van Regout en zijn fabrieken wekte weerstand in het land. Terwijl entrepreneurs als J.C. van Marken (gistfabriek, Delft) en C.T. Stork (machinefabriek, Hengelo) in de jaren zeventig van de negentiende eeuw al een 'feminiene overlegcultuur' (Hofstede, persoonlijke mededeling; zie ook Hofstede, 1978 ${ }^{49}$; d'Tribarne, 1989; en Van Iterson \& Olie, 1992, over de Nederlandse consensustraditie) in het leven riepen, nam het bevelsregime in de Regout-fabrieken in strengheid slechts toe. Deze discrepantie valt echter buiten de tijdsafbakening van deze studie. Een 'culturele' kijk op deze conflicten (die culmineerden in de beruchte confrontatie tussen de commissie van de Parlementaire Enquête van 1887 en Regout's zonen) zou een verhelderende aanvulling kunnen vormen op wat daarover al is geschreven. Ook Petrus Regout's orangistische en ultra-montaanse ${ }^{50}$ houding kunnen in dit licht worden bezien.

Op de dimensie onzekerheidsvermijding (UAI) (van sterk tot zwak) verschillen de scores eveneens opvallend: tegen een hoge tot extreem hoge score van respectievelijk Frankrijk en België staat een gemiddelde tot gematigd hoge score van Nederland en Duitsland en een betrekkelijk lage van Groot-Brittanië. Het contrast België-Nederland is op deze dimensie nog groter: 41 'punten' verschil, tegen 27 bij machtsafstand. Kan men bij Regout een hoge mate van onzekerheidsvermijding onderkennen? Niet in strategisch opzicht, dus; zijn speculatieve gedrag stak duidelijk af tegen het risico-averse beleggingsgedrag van Noordnederlandse handelskapi-

48 Nog niet vermeld is dat de stad van de late Middeleeuwen tot de Franse Tijd onder tweeherig bestuur heeft gestan: van de hertogen van Brabant en vervolgens de Staten-Generaal enerzijds en van de prins-bisschoppen van Luik anderaijds.

49 In dit artikel beschrift Hofstede hoe de 'sociale consinucteur' I.C. van Marken de eerste ondernemingsraad van Nederland (1878) oprichtte, 'de Kern' geheten, die een gekozen voorzitter kende, iemand anders dan Van Marken zelf, en die een aanzienlijke zelfstandigheid tegenover de directie verwierf.

50 Over de katholieke entrepreneurs van Roubaix-Tourcoing heeft Landes geconcludeerd: 'Success in business becomes a mode of self-assertion; and religion, rather than a prime mover, is itself a symptom of this drive" (1976:69). Ik ben ervan overtuigd dat dit ook voor Petrus Regout geldt. Max Weber zou aan de Boschstrat weinig hebben gevonden. 
talisten. Wat betreft de interne organisatie lijkt het niet te boud te stellen dat Regout geen risiconemer was; waarvan ook zijn stijl van werving, behoud en beheersing (zie ook de masculiniteitwfemininiteitdimensie) nog zal getuigen. Volgens Hofstede wordt onzekerheid bestreden met technologie, wetten en religie. Technologie draagt bij aan de vermijding van onzekerheden door de natuur veroorzaakt; wetten aan de onzekerheden in menselijk gedrag; religie aan metafysische onzekerheden (ibid., p. 110). In Westerse religies echter treft juist de combinatie van het transcendente met het morele: geformuleerde antwoorden op metafysische problemen worden gebruikt (zo men wil: misbruikt) om het gedrag van mensen te beïnvloeden. Daarom zie ik religie ook als een manier om onzekerheden in menselijk gedrag te reduceren. In werving, behoud en beheersing van arbeiders kan men dan ook naast wetten (contracten, reglementen) religieuze praktijken herkennen: ik herinner slechts aan de verplichting voor leden van Regout's ziekenkassen om de jaarlijkse Hoogmis bij te wonen voor de zielerust van de overleden leden en aan de zondagsdienst waar ten behoeve van de Franstalige arbeiders in het Frans moest worden gepreekt. Belangrijker dan deze praktijken was de niet aflatende nadruk op de zegeningen van het katholieke geloof waarmee Regout zijn handelingen en optreden kleurde en die hem alleen al met meer vrijzinnige elites op lokaal niveau in botsing bracht.

Ook de masculiniteit-femininiteitdimensie (MAS) geeft opvallende scoreverschillen te zien: tegen een gemiddelde score van België en gematigd hoge van Engeland en Duitsland staat een tamelijk lage van Frankrijk en een extreem lage van Nederland. Slechts Noorwegen en Zweden verslaan Nederland in feminimiteit. Door Nederland's uitzonderlijk lage score op masculiniteit is het verschil tussen België en Nederland vrijwel gelijk aan het verschil op de onzekerheidsdimensie: 40 'punter'.

In Frankrijk bestonden veel hiërarchische sociale experimenten ten behoeve van arbeiders. ${ }^{51}$ Deze strak geleide vorm van zorgzaamheid doet een combinatie van grote machtsafstand (en onzekerheidsvermijding) met femininiteit vermoeden. Dat geeft de Franse scores ook te zien: PDI 68, UAI 86 en MAS 43. Daarmee vergeleken scoort België aan de masculiene kant van de dimensie: MAS 54. Het verschil met Frankrijk is echter niet zo groot: 11 'punten'. Het mag dan ook niet veel verwondering wekken als Belgische en 'Belgische' fabrikanten een paternalistische houding jegens hun arbeiders ten toon spreidden. In een Nederlandse context, daarentegen, zal dit patemalisme om twee redenen een "harde"

51 Bijvoorbeeld de cités onvrières bij Claude Ledoux" zoutfabriek Saline Royale en Henri de Gorge's steenkoolmijn Le Grand-Hornu (weliswaar in België, maar De Gorge was een Fransman); enkele decennia later de familistères bij Godin's kachelfabriek in Guise; vgl. ook Hofstede \& De Bettignies, 1974, over een twintigste-eeuws Frans sociaal experiment bij de werkgemeenschap Boimondau. 
indruk maken. Door de grote scoreverschillen op de MAS-dimensie tussen Nederland en België zal cen naar multinationale maatstaven betrekkelijk feminiene praktijk in Nederlandse ogen zeer masculien lijken. Ten tweede is de manier waarop deze praktijk werd uitgeoefend - hiërarchisch, want hogere machtsafstand, en sterk gereguleerd, want hogere onzekerheidsvermijding - voor Nederlanders, met hun egalitaristische en tolerante mentaliteit, eveneens te hardvochtig. Deze opmerkingen zijn niet bedoeld als vergoelijking voor bepaalde fabrikantenpraktijken, maar als een vingerwijzing hoe dergelijke conflicten ook kunnen worden bestudeerd.

In deze inschattingen is met nuanceringen als 'grotendeels', "doorgaans", 'in het algemeen' geprobeerd een belangrijk aggregatie-probleem recht te doen. In Hofstede's onderzoek is gekeken naar nationale verschillen in gemiddelden van antwoorden per land. Inderdaad, '[s]tatements about culture are not statements about individuals' (ibid., p. 253). Het zou een voorbeeld van ecological fallacy zijn als Regout wordt gepresenteerd als een 'gemiddelde Belg'. Die bestaat niet en heeft nooit bestaan, want: '[t]he structure of national (and also of other) cultures differs from the structure of individual personalities' (ibid., p. 255). Groepen of collectiviteiten of figuraties van mensen kennen hun eigen dynamiek, relatief autonoom van de bedoelingen en wensen van de individuen waaruit deze groepen bestaan.

Uit bovenstaande alinea's is geen krachtiger conclusie te halen dan dat het culturele argument, dat kan worden verwoord via verschillen op nationale cultuurdimensies, met betrekking tot déze casus niet faalt. ${ }^{52} \mathrm{Ik}$ zie vooralsmog geen onoverkomelijke tegenstrijdigheden tussen de waarden van deze ene historische persoon en een anderhalve eeuw later gevonden nationaal patroon.

52 Een culturele analyse van de Nederlandse reactie op Regout's daden en denkbeelden zou meer (en meer betrouwbare) resultaten opleveren, want in dat geval geldt de ecological fallacy niet. Maar dat is een mooi onderwerp voor een andere studie. 


\section{HOOFDSTUK 4}

\section{PROBLEMEN VAN WERVING, BEHOUD EN BEHEERSING VAN ARBEID IN HET MODER NE FABRIEKSSYSTEEM IN DE EERSTE DECENNIA VAN DE INDUSTRIELE REVOLUTIE}

\subsection{De geboorte van het fabriekssysteem ${ }^{1}$}

Of late, several merchants have become manufacturers of Cloth, and, for the better carrying on such manufactory, have erected very large Buildings which are called Factories, wherein they intend to employ Clothiers as their Servants, so that persons, who, with their Families, have been dispersed as before mentioned, will be associated together within, or near those buildings in a dependant State'

(Uit een 'Bill' opgesteld door kleine 'master-clothiers' uit de West Riding, 1795, geciteerd in Thompson, 1980: 598).

'Lasciate ogni autonomia, voi chi entrate!'

(Friedrich Engels, 'On Authority', Karl Marx \& Friedrich Engels, Selected Works, deel 2, Moskou: 1969 (1873))

De Industriële Revolutie verwijst naar een aantal verweven accumulaties, concentraties en veranderingen in Westeuropese samenlevingen: accumulaties van kapitaal, concentraties van arbeid, veranderingen van technieken, produktieverhoudingen en organisatie. ${ }^{2}$ In dit hoofdstuk zullen de veranderingen van organisatie nader worden bekeken. Deze laten zich samenvatten in één woord: fabriekssysteem.

1 Een eendere, meer uitgebreide versie van de eerste drie paragrafen van dit hoofdstuk verscheen als working paper 89-021 van de Faculteit der Economische Wetenschappen, Rijksuniversiteit Limburg.

2 Wie aan de Universiteil van Amsterdam sociologie heet gestudeerd dient deze zin af te maken met: ...die door veranderingen in de nationale en internationale context waren teweeggebracht of begunstigd en die op hun beurt belangrije consequenties voor die wijdere samenlevingen hadden. 
Als men het heeft over de opkomst van het fabriekssysteem als kenmerkend voor de Industriële Revolutie, wil dat niet zeggen dat er voordien niet in grote produktie-eenheden werd gewerkt. Lang voor de geboorte van het fabriekssysteem werd in de ijzerindustrie, de chemische industrie, de machinefabricage en de scheepsbouw werk verricht door grote groepen bij elkaar gebrachte arbeiders. ${ }^{3}$ In deze industrieën konden het belangrijkste werk niet aan thuiswerkers worden uitbesteed. Toch kunnen we niet spreken van moderne fabrieken. Aan twee belangrijke criteria werd voldlaan - concentratie van produktie en handhaving van discipline maar aan één niet: het werktempo werd niet gedicteerd door gestaag werkende machines. ${ }^{4}$ In tegenstelling tot de laat-achttiende-eeuwse Engelse textielfabrieken ${ }^{5}$ (door velen beschouwd als de motor van de Industriële Revolutie) werd het tempo in deze traditionele fabrieken bepaald door discontinu werkende kapitaalgoederen (bijwoorbeeld een gietoven, die steeds weer op de juiste temperatuur moest worden gebracht) of door orders (zoals in de scheepsbouw en machinefabricage). Het werk geschiedde bij vlagen. Korte perioden die inspanning en concentratie vereisten werden afgewisseld met tijden dat er weinig te doen was.

David S. Landes, op wiens studie over de industriële modernisering in verschillende Europese landen, The Unbound Prometheus (1969), deze paragraaf in belangrijke mate is gebaseerd, noemt deze fabrieken 'mens-tempo' produktie-eenheden, in tegenstelling tot de moderne fabrieken die hij van het adjectief 'machine-tempo' voorziet. 'Mens-tempo' vind ik, gelet op de discontinu werkende kapitaalgoederen en orders, ongelukkig gekozen. Als er al een inherent menselijk tempo bestaat, kreeg dat in de traditionele fabrieken niet de kans zich te tonen. Het is het beter om van 'discontinu'

3 Om niet te spreken van gezamenlijke inspanningen als de Egyptische pyramiden, de Chinese muur, de Romeinse aquaducten, de Gotische kathedralen (Braverman, 1974: 64).

4 Preciezer: machines die door altij-stromend water of stoom werden aangedreven en die onafgebroken - direkt of indirekt - werktuigmachines bewogen. Er waren i) machines voor de beweging (waterrad, stoommachine, ii) mechanismen voor de overbrenging en iii) werktuigmachines, waarmee de produkten werden vervardigd (Marx, 1972: 275-6). Het is deze derde machine die volgens Marx 'het uilgangspunt vormde van de industriële revolutie in de achttiende eeuw" (ibid., p. 276).

5 Mar ook hierop waren uitzonderingen. Niet alle textielfabrieken in het laatachttiende-eeuwse Engeland kenden het fabriekssysteem. Die van Benjamin Gott in Leeds, bijvoorbeeld, was wel groot, maar er stonden slechts een paar handgetouwen. Ook de afwerkingshandelingen werden zonder hulp van moderne machines verricht (Thompson, 1980: 310). 
versus 'continu' te spreken, of eenvoudig van 'traditioneel' versus "modern'.6

De geboorte van het fabriekssysteem in de textielfabricage, die kan dienen als een model voor dit systeem, is mede verklaarbaar uit inherente fricties in het uitbesteedsysteem. ${ }^{7}$ Deze fricties volgden uit het feit dat de thuiswerkers i) vrijelijk konden beschikken over de grondstoffen, halffabrikaten en produktiemiddelen (die vaak niet hun eigendom waren), ii) niet werden gesuperviseerd tijdens hun arbeid en iii) niet contractueel of moreel aan de uitbesteder waren gebonden. Hierin ligt de oorzaak voor de verduistering van ruwe katoen en wol en gereedschappen, de schommelingen in kwaliteit van de geweven en gesponmen produkten, de onregelmatige produktie en het plotseling beëindigen van de relatie door de thuiswerkers omdat ze voor een andere uitbesteder gingen werken of zelf uitbesteder werden. Uitbesteders die naar omzetverhoging streefden zagen zich verplicht thuiswerkers in te schakelen die zo ver weg woonden dat, door de hoge transportkosten, hun meerwaarde te niet ging.

Doordat het uitbesteedsysteem aan het eind van de achttiende eeuw onprofijtelijk dreigde te worden, begonnen Engelse entrepreneurs meer en meer te denken aan een alternatieve wijze van organisalie van de produktie. Het samenbrengen van de thuiswerkers in éen ruimte kende als grote voordeel dat hun werk door opzichters en machines ${ }^{8}$ kon worden gesuperviseerd en gereguleerd, zodat er minder verduistering kon optreden, gelijkmatige kwaliteit kon worden afgedwongen en vaste werkuren konden gesteld. Een ander voordeel was dat het werktempo en daarmee de produktiviteit kon worden verhoogd, terwijl de machines ook nog eventuele tekorten aan arbeidskrachten konden opvullen.

6 Ondanks de fundamentele verschillen groeiden de traditionele fabrieken in de loop van de negentiende eetw toe naar de modeme. Dankzij beter, effectiever gereedschap werd in de discontinue produktie-eenheden de gestadige naw keurigheid van het spinnen en weven in het fabriekssysteem benaderd. Ook in omvang deden veel traditionele fabrieken viet onder voor de moderne. Zo telde de Engelse ijzerfabriek Dowlais rond 18507000 arbeiders. Toch was deze groei in precisie, regelmat en omvang slechts gradueel; er trad geen revolutie in het produktie-proces op - en dat is juist wat het fabriekssysteem kenmerkt.

7 Uitbesteedsysteem: een deel van de produktie wordt, vaak via tussenpersonen, uitbesteed aan thuiswerkenden, meest mensen die in de eerste plaats in de landbouw of veeteelt werkzaam waren.

${ }^{8}$ Denk aan Charles Babbage's uitspraak: 'One great advantage which we may derive from machinery, is from the check which it affords against the inattention, the idleness, or the dishonesty of human agents" (1832, geciteerd in Braverman, 1974: 195). 
Met machines is het tweede grote voordeel genoemd - en daarmee een andere zwaarwegende verklaring voor de geboorte van het fabriekssysteem gegeven. Maakte in de discontinue industrieën de aard, omvang en complexiteit van het produkt thuiswerken onmogelijk (denk aan het bouwen van een schip), in met name de textielfabricage was het voorall de technische vooruitgang van apparatuur en gereedschappen die daarvoor zorgde (een door waterkracht of stoom aangedreven machine kon men doorgaans $^{9}$ miet thuis hebben. Dit dubbele motief - fricties in het uitbesteedsysteem en technische vooruitgang - voor concentratie kan men herkennen in de Vervierse wolindustrie, waarover in het vorige hoofdstuk iets is gezegd. Daarmee werd deze Oostbellgische stad éen van de continentale geboorteplaatsen van het fabriekssysteem.

Bij de eerste generatie moderne fabrieken in Engeland moet men niet denken aan de grote, meerdere verdiepingen hoge gebouwen die rond 1800 verschenen. Het waren eerder uitgebreide (vgl. Braverman, 1974: 5919) en opnieuw ingerichte werkplaatsen (ateliers, manufacturen ${ }^{11}$ ), waar niet meer dan een dozijn arbeiders aan, bijvoorbeeld, een of twee spinmachines (jemies of mules) en een kaardmachine werkten. Ook werden deze nieuwe fabriekjes ingericht in omgebouwde huizen en bovenverdiepingen, of, op het continent, in leegstaande gebouwen, zoals de door de Fransen geconfisceerde kloosters in de Zuidelijke Nederlanden (zie verschillende delen (o.a. 4 \& 8) van Le Patrimoine, 1975).

Dat werkplaatsen geleidelijk overgingen in moderne fabrieken kan de foute indruk wekken dat hier sprake is van opeenvolgende stadia in de industrièle produktie en organisatie. Men kan niet zeggen dat er eerst in werkplaatsen, in discontinue fabrieken of thuis werd gewerkt en daarna in continue fabrieken. Daarvoor hebben de vier genoemde systemen - de manufactuur, de traditionele fabriek, het uitbesteedsysteem en de moderne fabriek - te lang naast elkaar bestaan (vgl. Braverman, 1974: 60), zelfs tot op heden. Juist doordat zij grote verschillen vertoonden en daarmee competitieve voordelen genoten, bestond er continuiteit bij alle vier.

De voordelen van het uitbesteed- en het manufactuursysteem zijn deels te vinden in die systemen zelf, deels in de eisen van het fabriekssysteem. In

9 Een witzondering vornden de zogenaminde coftage factories (een term van John Prest, geciteerd in Landes, 1966: 14) in Coventry, wat stoommachines tientallen onahankelijke spinners in hun huisjes van energie voorzagen.

10 "These early workshops were simply agglomenations of smaller units of production, reflecting litte change in traditional methods [...]".

11 Voor een gedetailleerde beschrijving van de manufactuur zie Marx, 1972, h. 12. pp, $246-74$ 
moderne fabrieken kon goedkoper worden geproduceerd; de werkplaatsen daarentegen konden voordeliger werken bij levering op bestelling. Het fabriekssysteem betekende het einde, maar ook het begin van veel werkplaatsen. De vraag naar het vervaardigen en onderhouden van machines, bijvoorbeeld, riep vele kleine ambachtelijke bedrijven in het leven.

Ook het huisindustriële systeem genoot enkele voordelen die het voortbestaan van deze vorm verklaren - ondanks het grote nadeel dat de thuiswerkende ambachtsman geen gerede produkten van de hoogste kwaliteit kon maken noch kon concurreren op het gebied van massaproduktie. Het systeem was echter bijzonder geschikt voor industrieën met een zich nog ontwikkelende technologie, omdat de thuiswerkers daar goed mee overweg konden en er hun produktiviteit gemakkelijker mee konden verhogen dan in de fabrieken. Dit voordeel valt uiteraard snel weg wanneer eenmaal de technologie een bepaald niveau heeft bereikt; dan wordt het fabriekssysteem profijtelijker. Ten tweede was de thuiswerker betrekkelijk goedkoop: (i) hij genoot, als gezegd, doorgaans inkomsten uit agrarische aktiviteiten en (ii) hij was bereid in ruil voor de vrijheid zelf zijn tempo en tijdsindeling te kunnen bepalen inkomsten te derven. Voor de uitbesteder gold natuurlijk nog het voordeel van de geringe vaste kosten die in kapitaalgoederen hoefden te worden gestoken. Ten slotte kon hij ook gemakkelijker mensen ontslaan dan in de twee andere systemen. Om deze redenen bleef, met name in het weven of de spijkerfabricage, het systeem voortbestaan. Ook bleef het systeem voortbestaan in vereniging met fabrieken, als reservecapaciteit. ${ }^{12}$

Ondanks de snelle opkomst van het fabriekssysteem werkte rond 1850 zelfs in Engeland de meerderheid van de bevolking nog in de landbouw of als huisbediende of in de discontinue industrieën, zoals huizenbouw, schoen- en klerenfabricage. Bovendien was de moderne industrie zelf voor een belangrijk deel nog kleinschalig: de gemiddelde fabriek gaf aan niet meer dan 200 mensen werk. Dit neemt niet weg dat er over de eerste decennia een duidelijke trend kan worden waargenomen: met name in de leer-, papier- en metaalindustrie (die de textielindustrie op een afstand van twee generaties volgden) nam het aantal moderne fabrieken toe - en binnen die fabrieken de produktiviteit.

Ook werd de kleine nijverheid meer en meer afhankelijk van het fabriekssysteem. De kleinere bedrijven die halverwege de negentiende eeuw nog floreerden, deden dat voornamelijk dankzij de vraag gegene-

12 Vergelijk: "The yourneyman complained that the factories put out more work to out-weavers in brisk times, and dismissed them without compunction in slack, whereas the small masiter-clothiers still sought to find employment for their own journeymen' (Thompson, 1980: 310). 
reerd door de groei van het fabriekssysteem: niet alleen de vraag van de grote moderne fabrieken zelf, maar ook van degenen die er werkten en van de steden die eromheen uit de grond schoten. Dezelfde toegenomen afhankelijkheid geldt ook voor de Engelse landbouw, handel en banken.

Landes omschrijft het fabriekssysteem - te ruim, naar mijn smaak - als het resultaat van het bijeenbrengen van grote aantallen arbeiders in eén ruimte, waar ze onder supervisie gedisciplineerd hun taken verrichten (1969: 114).13 In de woorden 'taken' en 'gedisciplineerd" kan men twee van de genoemde beweegredenen van entrepreneurs om arbeiders te concentreren, terugvinden. 'Taken' verwijst dan naar het samenhangend geheel van voortgeschreden technologie, toegenomen arbeidsdeling en com= plexiteit van de produkten. 'Gedisciplineerd' verwijst naar de manier waarop die taken dienden te worden uitgevoerd: zonder te verduisteren, verspillen of slechte kwaliteit af te leveren, maar ook gewillig, attent, in het ritme zoals dat door machines en voormannen ${ }^{14}$ werd gedicteerd, en met betrachting van de goede zeden. In één zin: produktiever, beter, beschaafder. 15

No longer could the spinner turn her wheel and the weaver throw his shuttle at home, free of supervision, both in their own good time. Now the work had to be done in a factory, at a pace set by tireless, inanimate equipment, as part of a large team that had to begin, pause and stop in unison - all under the close eye of overseers, enforcing assiduity by moral, pecuniary, occasionaly even physical means of compulsion. The factory was a new kind of prison; the clock a new kind of jailer' (Landes, 1969: 4.3).

Dezelfde Landes schrijft elders: "[..] the essence of the factory is discipline - in the opportunily it affords for the direction and coordination of labor' (1966: 14).

13 De socioloog Abram de Swaan noemt als kenmerken van het fabriekssysteem: standaardisatie, formalisering en de oefening in punctualiteit en discipline (1989: 70).

14 Door Marx bijtend, maar niet onbillijk 'onderofficieren' genoemd, "die tijdens het arbeidsproces namens het kapitaal het bevel voeren" (1972: 243). De militaire metafoor, waarvan Marx zich dikwijls bedient, ligt voor de hand.

${ }^{15} \mathrm{Nu}$ al zij opgemerkt dat fabrikanten dit laatste - beschaving - ook probeerden te verbeteren buiten de werkwloer. Daarom kan men deze vorm van beheersing extra muros beschouwen als een onderdeel van het fabriekssysteem. 

ongeschoolde) (mannelijke, vrouwelijke en minderjarige) arbeid

Waarom wilden fabrikanten beletten dat hun arbeiders naar een andere werkgever overstapten of voor zichzelf begonnen? Ten eerste werd arbeid tijdens de Industriele Revolutie steeds schaarser (de vraag naar arbeid groeide sneller dan het aanbod); ten tweede waren er kosten van werving, opleiding, bijscholing en beschaving in arbeiders gestoken. In de decennia dat er nog (bijna) geen technisch onderwijs bestond, zagen fabrikanten zich genoodzaakt hun arbeiders op de werkvloer de benodigde kenmis en vaardigheden en de gewenste houding bij te brengen. Indien deze kosten al waren terugverdiend, was het nòg nadelig als er naar een andere fabrikant werd overgestapt, want deze hoefde dan genoemde kosten voor de overstapper niet meer te maken (vgl. Dhondt, 1954: 309-24). Een derde reden kan zijn geweest: prestigeverlies. Een hoog personeelsverloop mocht duiden op ondermaatse leiding.

Met de toenemende schaarste van arbeid is ook de belangrijkste reden genoemd voor de bemoeienissen van fabrikanten om arbeiders aan te trekken. Een aantal factoren die het hen daarbij extra moeilijk maakte:

\section{1) het (aanoankelijk) rurale karakter wan de industrie:}

In de eerste decennia van de Industriële Revolutie werden fabrieken vaak buiten de steden gebouwd. Ten eerste vanwege de vindplaats van grondstoffen, zoals steenkolen of ijzererts, of de aanwezigheid van energiebronnen, zoals een rivier met een sterk verval (Bendix, 1963: 35). Ten tweede omdat de arbeidsreserve buiten de steden, door technische verbeteringen in de landbouw bovenop een forse bevolkingsgroei, omvangrijk en goedkoop was. Het animo om zich te schikken naar het industriële ritme ${ }^{16}$ met zijn nieuwe 'time-discipline' (Thompson, 1967: 85, 90; ook: SohnRethel, 1978) was echter niet groot, zodat er gedeeltelijk moest worden geworven onder de arbeidsreserve in de steden, waar weer weinig enthousiasme bestond op het platteland te gaan wonen. Deze problemen kon men het eerst in het achttiende-eeuwse Engeland waarnemen ${ }^{17}$,

16 Naast het vertrouwde begrip "industrieel ritme' zou men ook kunnen spreken van 'industriele ruimte": niet alleen diende het werk te worden verricht in een bepaald tempo, maar ook, zoals we hebben gezien, in een min of meer afgesloten ruimte. Ook dit aspect van 'opgesloten te zitten' wekte weerstanden.

$17 \mathrm{Vgl}$. Chapman, 1967: 159-162, over de cottages behind a broad avenue of trees die Richard Arkwright rond 1777 in Cromford bouwde om geschoolde arbeiders uit de steden te lokken, plus andere attractiemiddelen die hij aanwendde, zoals 'sick-clubs and providient societies', een café en melkkoeien, die aan de belangrijkste arbeiders werden weggegeven. 
maar daarna ook in het Noordfranse en Waalse industriegebied, in Lotharingen en het Ruhrgebied.

\section{2) het (latere) urbane karakter van de industrie:}

Naderhand, toen stromend water als belangrijkste energiebron werd vervangen door steenkool, verplaatsten veel industriëlen hun fabrieken naar de steden, waar de transportmogelijkheden groter waren en daarmee de markten beter bereikbaar (Bendix, 1963: 35). 'De stoommachine is de vader van de fabrieksstad, aldus een Engelse inspecteur van fabrieken in 1866 (geciteerd in Marx, 1972: 279). Inmiddels waren ook rondom de rurale industrieën stedelijke gebieden gegroeid: boomtowns als Roubaix, Verviers, Duisburg en Essen.

Hier ziet men het omgekeerde: er werd, bij een te krappe stedelijke arbeidsreserve, getracht potentiële arbeiders van buiten de stad de fabriekspoorten binnen te lokken (Bendix, 1963: 35). Ook dit stuitte op problemen. Net als de stedelijke arbeiders waren deze migranten vaak weinig genegen om de overstap te maken (ibid.). Misschien waren hun aanpassingsproblemen nog groter. Dat mag blijken uit de hardnekkigheid waarmee het rurale ritme, gedicteerd door de seizoenen en de daarbij behorende arbeid, hun levens bleef bepalen. Veel fabrieksarbeiders van rurale afkomst 'pendelden' of namen in de zomer ontslag en keerden terug om mee te helpen oogsten. Deze 'restless and migratory spirit' en loose and wandering habits' (beide aanhalingen uit Thompson, 1980: 394) stemden veel laat-achttiende-eeuwse entrepreneurs (en leden van andere elites) ongerust. ${ }^{18}$ Daarbij komt dat voor de rurale en urbane arbeiders in de stad de lokroep van andere fabrikanten duidelijker hoorbaar was. Bovendien zijn de kosten van veranderen van werkgever lager als de andere aanbieder in dezelfde plaats is gevestigd.

3) de beroepstrots van de ambachtslieden:

Het werven van geschoolde ${ }^{19}$ arbeiders, in of buiten de steden, confronteerde de fabrikanten met andere problemen. Veel ambachtslieden (semi-)zelfstandigen of uit de werkplaatsen - voelden het als een degradatie om in fabrieken te gaan werken. Dat betekende vaak het verlies van

18 Volgens de historicus Peter Stearns, echter, hadden de rurale arbeiders, zeker aanvankelijk, niet de grootste aanpassingsproblemen. Ze waren gewend lange dagen te maken. En door fabrieks- en landwerk af te wisselen wisten ze het eerste draaglijk the houden: "[..] by changing jobs and moving they restored some of the aspects of seasonality to which they had been accustomed.' 'Thus large groups of workers, even in advanced industries, such as metallurgy, fought with some succes to preserve a traditional concept of work (1975: 2).

19 Dat wil zeggen: geschoold in een vak, een ambacht - niet geschoold in (een) bepaalde beperkte handeling(en). 
voorrechten, van gezag over leerlingen, van zelfstandigheid en daaraan ontleende trots, van eigendom van gereedschappen, van een eigen wijze van produceren (Bendix, 1963: 23), van de sfeer van het atelier, van de wrijheid van het eigen huis, kortom, van een specifieke manier van leven en werken. Hun beroepsloyaliteit was groter dan hun potentiële bedrijfsloyaliteit.

Het lukte fabrikanten slechts deze vaklieden aan te trekken tegen hoge lonen, gunstige arbeidswoorwaarden en aantrekkelijke condities buiten de werkwloer. Toch bleef bij hen de neiging sterk aanwezig om, al was het tijdelijk, terug te keren naar hun oude situatie.

Om dit probleem van werving en behoud van arbeid te overwinnen moesten de fabrikanten, als gezegd, een arsenaal aan middelen inzetten ${ }^{20} \mathrm{om}$ geschoolde en ongeschoolde, stedelijke en rurale, migrerende en nietmigrerende, mannelijke, vrouwelijke en minderjarige arbeiders te bewegen blijvend hun diensten bij hen aan te bieden. Ik maak een onderscheid tussen attractie-, ontmoedigings-, restrictie-- en bemoedigingsmiddelen.

De attractiemiddelen, ingezet om arbeiders te werven, verdeell ik onder in drie categorieër.

1) Het belangrijkste middel was natuurlijk de prijs die voor arbeid werd betaald. Afhankelijk van de herkomst en scholing van de arbeiders zagen de fabrikanten zich verplicht, bij een overigens gelijkblijvende preferentie van arbeidskrachten, een hoger loon ${ }^{21}$ aan te bieden dan het vigerende in de bedeling en ambachtelijke nijverheid. Aan beide werd immers de voorkeur gegeven boven werken in het fabriekssysteem. Hetzelfde zal in veel gevallen ook voor de landbouw, het uitbesteedsysteem en de traditionele fabrieken hebben gegolden.

Prijsgerelateerde attractiemiddelen konden zijn het gehanteerde beloningssysteem (stuk- of tijdloon) en de frequentie van uitbetaling: dagelijks en wekelijks (doorgaans: op zaterdag). Eén keer in de twee weken, en zeker één keer per maand werd als heel ongunstig opgevat. Het impliceerde in de regel dat aan het eind van zo een lange periode op krediet moest worden gekocht. Tegen wekelijkse uitbetaling op de zaterdag hadden veel fabrikanten weer bezwaar, omdat dan een belangrijk deel meteen in het café werd opgemaakt. Daarom gingen sommige fabrikanten ertoe over om op donderdag, of nòg eerder, uit te betalen, zodat de kans toe-

20 Telkens wanneer er wordt gesproken van het 'inzetten' van middelen, moet worden bedacht dat de industriële entrepreneurs deze middelen niet slechts hebben overgenomen (van andere, al dan niet industriële, entrepreneurs), maar ook zèlf bedacht en ontwikkeld.

${ }^{21}$ Men kan hier ook denken aan een gunstiger munteenheid. 
nam dat althans een deel van het loon aan het huishouden werd gespendeerd (Brugmans, 1975: 147).

2) Een verzameling middelen die fabrikanten eveneens aanwendden om arbeid te werven, laat zich rubriceren onder wat nu heet: secundaire arbeidsvoorwaarden. Daartoe konden behoren: gunstige regelingen met betrekking tot overwerk, nachtwerk en onaangenaam of risicovol werk, hygiënische en gezonde werkomstandigheden, premies en werkgarandering (bijwoorbeeld voor wie een bepaald minimum aan dienstjaren haalde), humatne (of althans niet inhumane) leiding, een zekere medezeggenschap, bezit van of vrije beschikking over gereedschappen, spaarmogelijkheden en ziekte-, ouderdoms- en ongevallenverzekeringen.

3) De derde categorie van attractiemiddelen betreft gunsten en faciliteiten die werden geboden 'buiten de werkvloer' - dat wil zeggen: alles dat niet direkt aan de produktie kan worden gerelateerd. Het maakt niet uit of deze gunsten en faciliteiten buiten de fabriekspoorten worden verleend of erbinnen. Eigen scholen ${ }^{22}$ kunnen zich òp het terrein bevinden, maar ook elders: in beide gevallen zijn het attractiemiddelen buiten de werkvloer. Naast scholen kan men denken aan leeszalen, gebedsruimten en andere immaterièle woorzieningen. Verder zetten fabrikanten ontspannings- en kunstbeoefeningsverenigingen op.

In de materiële sfeer kan men denken aan - opnieuw een anachronisme - werk-woonverkeerregelingen: arbeiders werden in paardewagens opgehaald en thuisgebracht; sommige fabrikanten lieten zelfs een tram- of spoorlijn aanleggen, die langs de dorpen waar hun arbeiders woonden, voerde. Ook bedrijfswinkels behoren tot deze categorie van attractiemiddelen: bakkers, slagerijen, apotheken, winkels voor huishoudelijke benodigdheden - op of bij het fabrieksterrein - die uitsluitend bedoeld waren voor arbeiders, of waar ze tegen korting konden inkopen.

De grens met het gebied van de beheersingsinstrumenten (zie volgende paragraaf) wordt hier vaag. Met het openen van deze winkels werd het verleidelijk arbeiders te verplichten er te kopen: het al vroeg omstreden fenomeen van de gedwongen winkelnering. Daarnaast $k$ wam het voor - en dat werd nog verwerpelijker geacht - dat arbeiders (gedeeltelijk) werden beloond met soms te hoog geprijsde produkten uit de bedrijfswinkels.

22. Leerscholen waar nieuwkomers de benodigde kennis en vaardigheden werd bijgebracht of reeds werkzame arbeiders werden bijgeschoold, maar ook algemene opleidingen, in het bijzonder voor de kinderen van de arbeiders, waarbij de nadruk meer ligt op het aankweken van het gewenste gedrag ofwel op 'karaktervorming". 
Het belangrijkste attractie-instrument buiten de werkvloer was huisvesting. ${ }^{23}$ Arbeiders werven met huisvesting kon men door een lagere huur te bedingen en/of méér comfort te bieden (méér ruimte, een tuin, betere materiaalkwaliteit, toilet, stromend, al dan niet warm, water) dan wat ze moesten betalen en gewend waren. Daarbij moesten fabrikanten meer en meer rekening houden met wat de concurrerende arbeiderswoningbouwspeculanten vroegen en boden. In het volgende hoofdstuk worden Regout's huisvestingsinitiatieven in detail besproken en in hun context geplaatst.

In de middelen die worden ingezet om arbeiders, eenmaal binnen de fabrieksmuren, het te bemoeilijken de werkrelatie te verbreken, vormen de bemoedigingsmiddelen één categorie en de ontmoedigings- en restrictiemiddelen een andere.

Sommige attractiemiddelen bemoedigden arbeiders tevens de werkrelatie te continueren. Wat lokt, bindt ook vaak. Een relatief hoog loon, een gunstige beloningswijze en frequentie van uitbetaling en alle gunsten en faciliteiten op en buiten de werkvloer, alle in eerste instantie bedoeld om te lokken, zijn naderhand goede redenen om niet de externe arbeidsmarkt te betreden. Humane/niet-inhumane leiding en een zekere mate van zeggenschap ziet men ook terug bij een belangrijk bemoedigingsmiddel: het aankweken van bedrijfsbinding - loyaliteit aan de fabrikant, de medearbeiders, het fabrieksspecifieke werk. Voert de leiding een humaan en participatief beleid, dan kunnen dat doelbewuste pogingen zijn de bedrijfsbinding te bevorderen. ${ }^{24}$

Ontmoedigingsmiddelen gaan meer in de richting van (dreigen met) sancties. Van het dreigement dat een arbeider die ontslag nam niet meer hoefde aan te kloppen, ging, vooral in streken met weinig vragers, een sterke

23 Dat is zowel het bouwen door fabrikanten van arbeiderswoningen als het voor bewoning door arbeiders opkopen en in gereedheid brengen (men denke hier vooral aan het opdelen in kamers) van bestaande woningen.

Soms werden er ook arbeiderswoningen gebouwd ondat er ter plekke cenvoudigweg geen andere behuizing stond. Toen men in de eerste decennia wan de industrialisering in Engeland voor de aandrijfenergie nog afhankelijk was van stromend water, moesten fabrieken in heuvel- of bergachlige gebieden worden gebouwd. Deze gebieden - bijvoorbeeld, de Midlands - waren niet zelden amper bewoond en fabrikanten zagen zich genoodzaakt zelf arbeiderswoningen te laten verrijzen (Chapman, 1967).

24 Bedrijfsbinding komt weer ter sprake in de volgende paragraaf. Loyaliteitsvergroting werd ook toegepast om het probleem op te lossen van beheersing var. de werkzaamheden zelf. 
dwang uit om te blijwen. Ook negatieve referenties ${ }^{25}$ of ongevraagde negatieve adviezen aan andere fabrikanten belemmerden de arbeidsmobiliteit. Een ander ontmoedigingsinstrument was kredietverlening aan arbeiders. Wie bij een andere fabrikant ging werken, werd steviger onder druk gezet (spoedig) af te betalen en verspeelde eventuele gunstige aflossingscondities. Een ontmoedigingsmiddel voor de korte termijn was het uitkeren van een woorschot op het loon, waarvan de afrekening op een later tijdstip plaatsvond.

Restrictiemiddelen zijn contractuee ${ }^{26}$ vastgelegde beperkingen in de handelingsvrijheid van arbeiders. De drie meest voorkomende restrictiemiddelen waren: i) een bepaling in het arbeidscontract aangaande de minimumperiode waarwoor een arbeider zich verplichtte te blijven werken, ii) de opzegtermijn, die vaak wèl voor arbeiders maar niet voor fabrikanten gold en iii) de bepaling dat er geen ontslag kon worden genomen als men nog schulden bij de fabrikant had. Andere restrictiemiddelen die in het arbeidscontract werden neergelegd, waren het verplicht opbouwen van een tegoed: wie (voortijdig) het bedrijf verliet, kon geen aanspraak meer maken op het al gedeponeerde bedrag. Ook buiten de werkvloer wendden fabrikanten restrictiemiddelen aan. In huurcontracten kwamen bepalingen voor dat bij ontslag ook de woning moest worden verlaten. Mede dank zij de grote woningnood alom bleek dit een effectief middel tot behoud van arbeid.

25 Denk aan het in Nederland snel in onbruik geraakte livret waarin antekeninger werden gemakt omtrent gedrag en ijver van de arbeiders; Goudswaard, 1981: 71)

26 Misschien is 'belofte' beter dan 'contract'. Een belofte - dat de andere partij in sommige situaties zal worden beloond of gestraft - is breder, want niet alle beloften hoeven contractueel te zijn vastgelegd. De tegenstelling tussen geschreven en ongeschreven beloften komt overigens niet geheel overeen met expliciete en impliciete belotten: sommige neergeschreven formuleringen kunnen veel impliciets bevatten; sommige ongeschreven beloften zijn zeer expliciet. 
 van arbeidskrachten}

Geschoolde, ongeschoolde, stedelijke, rurale, genigreerde, niet-gemigreerde arbeiders - allen, ongeacht geslacht of leetijd, kampten in moderne fabrieken met aanpassingsproblemen. ${ }^{28}$ In tegenstelling tot grondstoffen en kapitaal kenmerken mensen zich door individuele en collectieve zingeving, waardoor de overgang naar een nieuwe situatie kan worden bemoeilijkt. Deze aanpassingsproblemen ziet men ook weerspiegeld in de problemen die het fabriekssysteem aan de fabrikanten stelde. Dat waren in de eerste plaats problemen van discipline en coördinatie. ${ }^{29}$ Uiteraard, zoals overal, moest ervoor worden gezorgd dat de arbeidskrachten hun taken naar behoren uitvoerden. Dat betekende i) dat ze over de benodigde kennis en vaardigheden moesten beschikken teneinde de gewenste produktkwaliteit en efficiëntie in het gebruik van grondstoffen en kapitaalgoederen te halen en ii) dat ze - het nieuwe aan dit systeem - zich moesten voegen naar het industriële ritme, zoals dat werd gedicteerd door machine en voorman, ten einde de gewenste kwantiteit te halen en het zich-drukken (het 'shirking'-probleem uit de agency-theorie) tegen te gaan - 'to identify themselves with the unvarying regularity of the complex automaton' en 'to conquer their listless and restive habits', aldus

27 In plaats wan beheersing wordt vaak het Engelse control gehanteerd. Control is breder dan controleren: het houdt zowel controleren (of de taken naar behoren worden/zijn uitgevoerd) als bijsturen (van afwijkingen ten opzichte van de gestelde uitvoeringsnormen, waarin doelstellingen operationeel zijn vertaald). Daarnaast wordt ook motiveren genoemd: arbeid stimuleren om naar beste vermogen hur capaciteiten in te zetten.

$1 \mathrm{k}$ wil beheersing dan definiëren als het complex aktiviteiten van leidinggevenden dat zowel motiveren als controleren als bijsturen beval (vgl. Kumst el al. 1991: 72).

28 Stearns meent dat de aanpassingsproblemen voor binnenkomers naarmate de industrialisering zich voortzette alleen maar groter werden given the sophistication of the technology and management that now could be applied even to new workers' (1975: 2).

29. .waarbij niet moet worden vergeten dat het fabriekssysteem onder meer in het leven was geroepen on deze problemen te overwinnen.

30 Het begrip 'fabriek' betekende voor Ure: the idea of a vast automaton, composed of various mechanical and intellectual organs, acting in unintertupted concert for the production of a common object, all of them being subordirated to a self-regulated moving force' (aangehaald bij Thompson, 1968: 395). Ure's woorden waren overigens zonder veel hoop door hem neergeschreven. Hij meende dat het omvormen wan arbeiders tot 'useful factory hands' bijna onmogelijk was, althans ná hun puberteit, of ze nu van het platteland of uit de ambachten kwamen. 
Dr Andrew Ure in zijn Philosophy of Manufactures (1835, aangehaald bij Thompson, 1980: 395-6).

Zoals 'voegen' en 'identify' al aangeven, was een zekere instemming van de arbeiders onontbeerlijk wilden de fabrikanten met enig succes kunnen disciplineren en coördineren. De entrepreneurs hadden het liefst dat deze instemming steunde op innerlijke overtuiging. ${ }^{31}$ Thompson kan dat begrijpen. Hij spreekt van de noodzaak van 'inner compulsion' (1980: 3908, over Max Weber's protestantisme-kapitalismethese; zie uiteraard ook Weber zelf, 1976; of, summier, Giddens, 1971: 119-32), want externe prikkels werkten onvoldoende en tegen externe dwang werd gerebelleerd. ${ }^{32}$

Evenals religieuze en seculiere ideologische regimes berustten fabrieksregimes $^{33}$ op een moeilijk te ontwarren combinatie van i) dwang (van de kant van de fabrikanten) en ii) inschikkelijkheid of overtuiging (van de kant van de arbeiders). Industriële dwang ging soms gepaard met industriële drang: fabrieksregimes dwongen mensen tot werken in modeme fabrieken, maar na verloop van tijd meenden zij dat ze niet meer zonder konden. Toch rijst twijfel over het bestaan van innerlijke overtuiging als men de klachten van fabrikanten (zelfs 'verlichte' als Robert Owen; zie verderop) leest dat het hen maar niet lukte hun arbeiders te schikken naar het industriële ritme en bestaan. Uit de eerste decennia van de Industriële Revolutie stammen nauwelijks voorbeelden van mechanische solidariteit solidariteif op basis van gemeenschappelijke gevoelens en overtuigingen

31 De noodzaak van innerlijke overtuiging betrof, in de ogen van Ure, overigens alleen de volwassen arbeiders. Ure vond dat bij kinderen kon worden volstaan met opzichters en machines (Thompson, 1980: 396).

$32 \mathrm{Vgl}$.: "Whenever modern capitalism has begun its work of increasing the productivity of human labour by increasing its intensity, it has encountered the immensely stubborn resistance of [...] pre-capitalistic labour' (Weber, 1976: 60).

33 'Fabrieksregime' is beter dan 'fabriekssysteem'. Met 'regime' krijgt het dwingende karakter van deze wijze van produktie en organisatie meer nadruk dwingend voor de arbeiders, maar ook voor de fabrikanten. 'Regime' lijkt geschikt omdat het woord in het dagelijks gebruik zowel een heersend maatschappelijk bestel kan betekenen als een geheel van voorschriften en leefregels, waaraan individuen zich $\mathrm{min}$ of meer vrijwillig onderwerpen. Of: regime verwijst zowel naar de uitoefening van bestuur en beheer als naar gedragsvormen waaraan men zich moet of will houden. Dictatuur en dieet - beide kurnen met 'regime' worden aangeduid.

Deze dualiteit van machtsuitoefening en (zelf)disciplinering - het naast elkaar voórkomen èn met elkaar samenhangen - is ook juist kenmerkend voor de arbeidsverhoudingen binnen het moderne fabriekssysteem. Er werd er rechtstreeks dwang uitgeoefend (vgl. Elias' Frendzwang, 1969); er werd dwang uitgeaefend tot zelfbeheersing (vgl. Elias' Zwang zum Selbstzwang, ibid.) en arbeiders en fabrikanten gingen zichzelf meer en meer vrijwillig beheersen. 
van alle leden van een samenleving (Durkheim, 1984; geparafraseerd in, bijwoorbeeld, Lammers, 1983: 61-2; uitgebreider in Giddens, 1971, waarin het werk van Marx, Durkheim en Weber wordt vergeleken). Waren het niet uitsluitend de attractiemiddelen die de beweging richting fabriekspoorten verklaren? Niettemin lijkt tenminste een zekere berusting ${ }^{34}$ met het regime onmisbaar (vgl. ook Likert, 1961: 179-80). Geen boterham met tevredenheid maar een aardappel met een schouderophaal.

Een voorwaarde voor beide (kennis \& vaardigheden en voeging naar het industrieritme) was dat er zedelijke beheersing werd opgebracht. Het bijeenbrengen van mannen, vrouwen en kinderen in één ruimte droeg het gevaar in zich dat ze elkaar in de weg liepen, er ruzies losbraken, of sexuele contacten ${ }^{35}$ werden aangeknoopt, of dat men zich aan andere, als liederlijk (drinken) of ledig (spelletjes) beschouwde praktijken "te buiten ging'. ${ }^{36}$ In dat licht kan men Gibson Burrell's opmerking zien dat ' clapitalism learns to control the human body and its utilization of time so that by the present epoch it has become possible to say that to enter an

${ }^{34}$ Wat hier meehielp was dat ouders en kinderen niet zelden samen werden aangenomen (mede omdat ouders hun kinderen graag aamboden (Bendix, 1963: 36-40)). Doordat de ouders in hun begeleidersrol konden blifven functioneren, binnen het regime, konden ze er gemakkelijker vrede mee hebben. Enige decennia later kwam, door voortgeschreden techniek (d.w.z. mechanisering van de meeste werkzaambeden die door kinderen werden verricht) en verontwaardiging, aan de kinderarbeid een einde. Ondertussen waren meerdere generaties arbeiders in en nabij de fabriek opgegroeid.

35 '[.] the suppression of sexual relations is one of the first tasks the early factory employers set themselves' (Burrell, 1987: 99). Zie ook McKendrick over hoe Josiah Wedgwood deze problemen aampakte nadat hij bij een inspectie wan de administratie-afdeling had ontdekt dat the housekeeper was frolicking with the cassier" (1973: 61). Ontslag van de boosdoener was slechts de eerste stap in de desexualisatie van zijn arbeiders. Hiertoe werd hij volgens McKendrick eerder door overwegingen van efficiency dan van moraliteit geleid (ibid., p. 76).

36 Arbeidsconflicten blijven buiten beschouwing. In sommige landen, waaronder Nederland, was in de begindecennia van de Industriële Revolutie nog geen georganiseerde oppositie.

Overigens hadden arbeidsconflicten in het fabriekssysteem voor beide partijen een hogere prijs dan in de proto-industrie. Conflicten in het huisindustriële stelsel over uitbetaling, geleverde grondstoffen of verduistering bleven van beperkte omvang. In het ergste geval werd de relatie verbroken, waarna zowel huiswerker als uitbesteder snel een andere contractant had gevonden. Conflicten in het fabriekssysteem kregen vaak een massaal karakter - een klassekarakter. Voor de arbeiders was ontslag niet zelden dramatisch, omdat de alternatieven beperkt waren. Voor de fabrikant betekende een staking in eén afdeling al vaak dat de hele produktie moest worden stilgezet. 
organization is to give up control over one's disbursement of energy' (1987: 97). Hij meent dat "[..] sexual relations between subordinate men and women (or homosexuals ones for that matter) represent another major frontier of management control in organizational life (ibid., p. 99; vgl. ook Thompson over sex en het fabriekssysteem, 1980: 452). Ook in taalgebruik moesten arbeiders zich leren beheersen: subversieve en obscene uitlatingen vormden eveneens een bedreiging voor ordelijke arbeid ${ }^{37}$ en werden streng beboet. Dezelfde gevaren bestonden ook buiten de werkwloer, vooral in combinatie met alcoholgebruik. ${ }^{38}$ Voeging naar het industriële regime werd zo op indirekte wijze bedreigd door een 'verwildering' van de zeden in de vrije tijd. ${ }^{39}$

Daarmaast moesten de werkzaamheden - meer gespecialiseerd dan in de werkplaatsen en met kortere tussentijden dan in het uitbesteedsysteem nauwkeuriger op elkaar worden afgestemd dan in de andere organisatievormen (vgl. Marx, 1972: 237 e.v., over 'coöperatie' als op elkaar afgestemde arbeid; ook: Braverman, 1974: 59 e.v.). Dat leverde problemen van coördinatie op. Niet alleen werd het voor de fabrikanten moeilijker het produktieproces te structureren, het betekende tevens dat ervoor moest

37 De socioloog Pierre Bourdieu schrift over opvoeden: 'De omgang met het lichaam, met de taal en de tijd zijn alle bij uitstek het voorwerp van sociale controle: ontelbaar zijn de stukjes uitdrukkelijke opvoeding - om maar te zwijgen van de praktische, mimetische overdracht - die het gebruik van het lichaam betreffen ('zit recht', 'blijf af') of het gebruik van de taal ('zeg dit', 'zeg dat niet'). Via deze lichamelijke en linguistische discipline (die vaak ook een tijdsdiscipline meebrengt) worden objectieve structuren in het lichaam geïncorporeerd; de 'keuzes' die een bepaalde relatie tot de wereld inhouden, worden op die manier verinnerlijkt in de vorm van duurzame patronen die noch toegankelijk zijn voor het bewustzijn, noch - althans ten dele - door de will beinvloedbaar zijn (men denke aan alle automatismen)' (geciteerd in Pels, 1989: 117).

${ }^{38}$ Dit gevaar is door de arbeidersbeweging onderkend: één van de drie $K^{\prime} s$ is immers de kroeg. Ondat de andere twee verderfelijke $K^{\prime}$ s kerk en kapitaal waren, hebben veel kapitalisten (en geestelijken) de arbeidersbeweging als een zedelijke verwildering beschouwd.

${ }^{39}$ De fabrikanten hadden vooral van kermissen en andere volksfeesten last. Tijdens deze meerdaagse drinkfestijnen lag de produktie waak volledig stil. Veel arbeiclers kwamen pas dagen na afloop van het feest weer naar hun werk: ze vereerden dan niet alleen hun 'vaste' heilige, Saint-Monday - zeg maar: baalmandag - maar ook Saint-Tuesday en zo verder (Bendix, 1963: 38; Thompson, 1967: 75-6). Zelfs de assertieve Wedgwood voerde een vergeefse stijd tegen de 'wakes en fairs', zodat hij zich moest verontschuldigen voor een te late levering met de woorden: "the Men have gone madding after these Wakes's so that we could get little done' (McKendrick, 1966: 77). Pas een eeuw later was dit gebruik volledig uitgeroeid. 
worden gezorgd dat de arbeiders mér rekening gingen houden met andere arbeidskrachten vóor, na of in hetzelfde stadium van het produktieproces. Ook dit beheersingsprobleem had zich niet eerder in die mate doen gevoelen.

Samengevat: het fabrieksregime dwong fabrikanten arbeiders te disciplineren tot het leveren van constante kwaliteit, efficiënt gebruik van grondstoffen en kapitaalgoederen, een gelijkmatig werkritme, zelfbeheersing in omgangsvormen en lichamelijkheid en voortdurende, vreedzame en kuise samenwerking met andere arbeiders.

\section{Results control, action control en personnel control}

De Amerikaan Kenneth Merchant heeft een verhelderende indeling gemaakt van vormen van beheersing. Hij onderscheidt results control, action control en personnel control (1985). ${ }^{40}$ De literatuur over beheersing van organisaties heeft vrijwel uitsluitend betrekking op wat òp de werkvloer wordt verricht, of direkt daarmee in verband staat, zoals personeelsselectie. Maar ook beheersing van arbeidskrachten buiten de werkvloer kan men beschrijven in Merchant's termen. ${ }^{41}$

Merchant definieert beheersing als het beïnloeden van mensen om zich te gedragen zoals de organisatie wil dat ze zich gedragen. Hij noemt drie redenen voor mensen om dit niet te doen: omdat ze a) niet of onvoldoende weten wat door de leiding van hen wordt verwacht, b) niet of onvoldoende zijn gemotiveerd en c) om welke reden ook niet anders kunnen ('personal limitations'). Deze drie vormen van suboptimaal gedrag, uit het perspectief van de organisatieleiding, kunnen worden bestreden met de drie beheersingsvormen.

Results control (resultatenbeheersing) is beheersing via output. Individuen of groepen (zoals divisies) worden bekeken en (extrinsiek) beoordeeld op

${ }^{40}$ Merchant's indeling lijkt sterk op die van William $G$. Ouchi, die een onderscheid maakt tussen output measurement, behavior measurement en clan control (1979: 843). Omdat Ouchi deze derde beheersingsvorm koppelk aan een organisattievorm - de 'clan' - vind ik zijn indeling hier minder geschikt. Bijna alle vroege fabrieksregimes kenden een pyramidaal hiërarchische structuur; maar binmer die structuur herkent men verschillende beheersingsvormen. Daarom lijkt Merchant's indeling, walarin alleen vormen van beheersing worden onderscheiden, adequater.

${ }^{41}$ Fabrikanten konden ook de verhouding tussen 'op' en 'buiten' de werkvloer beinvloeden. Des te langer zij hun arbeiders lieten werken, des te korter vertoefden zij buiten de werkvloer. Vooral waar beheersing buiten de werkvloer grote problemen gaf, was werktijdverlenging een belangrijk alternatief beheersingsmiddel. 
hun gerealiseerde output vis-à-vis de gestelde output. Dit veronderstelt dat resultaten kunnen worden toegeschreven aan werkzaamheden van individuen of groepen, met andere woorden, dat deze werkzaamheden, of taken, dusdanig afgerond zijn dat het resultaat ervan meetbaar is (bijvoorbeeld: hoeveelheid produkt, toegevoegde waarde, winst), of aan een ander duidelijk criterium kunnen worden beoordeeld (zie ook: Child, 1984: 161).

Op arbeiders in het fabrieksregime is deze beheersingsvorm slechts van toepassing als hun werkzaamheden grotendeels onafhankelijk zijn van die van andere arbeidskrachten. Dit geldt voor (onderdelen van) produkten, die door één arbeider worden vervaardigd; het geldt ook alleen wanneer de produktie relatief autonoom van het door machine of voorman gedicteerde tempo geschiedt. In dergelijke gevallen kan of moet beheersing via resultaten worden toegepast, in het bijzonder met het instrument stukloon.

Het voordeel van resultatenbeheersing is het effect op de motivatie. Koppeling van beloning aan resultaten kan een positief effect hebben op de inzet van de arbeidskrachten (Grumbkow, 1982), al kwam het omgekeerde ook voor: arbeiders met een hoger loon gingen minder hard werken (Bendix, 1963: 35-6). Een ander mogelijk positief effect is dat an individuen en groepen méér onafhankelijkheid kan worden gegeven zonder dat er aan beheersmacht veel hoeft te worden ingeboet (Kunst, 1989b).

Als resultatencontrole kan worden toegepast, zijn de problemen van discipline en coördinatie minder nijpend - het disciplineprobleem omdat er een krachtige prikkel is tegen het-zich-drukken: prestatiebeloning; het coördinatieprobleem omdat bij genoemde werkzaamheden minder hoeft te worden samengewerkt.

Action control wordt gebruikt '[..] to ensure that individuals perform (or do not perform) certain actions that are known to be beneficial (or harmful) to the organization' (Merchant, 1985: 29). Deze aktiviteitenbeheersing verdeelt Merchant onder in behavorial constraints, preaction reviews, action accountability en redundancy.

Onder behavorial constraints (het opleggen van gedragsbeperkingen) vallen de matregelen die het bemoeilijken of onmogelijk maken dat er iets wordt gedaan dat niet mag. Dat kunnen fysieke beperkingen zijn, zoals sloten op gereedschapskasten of verboden toegang tot bepaalde ruimtes, maar ook beperkingen als resultaat van beslissingen over de organisatiestructuur, zoals centralisatie en scheiding van bevoegdheden. Hoewel Merchant ze niet noemt, kan men ook geschreven gedragsregels (denk aan reglementen) tot deze vorm van beheersing rekenen. ${ }^{42}$ Het spreekt dat

${ }^{42}$ Een navrant voorbeeld van een reglement van louter verboden met bijbehorende sancties biedt een lijst van boetebepalingen gehanteerd in een spinnerij in Tyldesley, bij Manchester. De lijst is door stakende spinners naar buiten 
het opleggen van gedragsbeperkingen een belangrijke rol hebben gespeeld in het fabrieksregime. ${ }^{43}$

Preaction reviews wil zeggen dat het werk van individuen wordt beoordeeld alvorens de aktiviteit is begonnen (het keuren van plannen) of beëindigd (zodat tussentijdse aanpassingen kunnen worden verricht). Deze beheersingsvorm speelde in het fabrieksregime een bescheiden rol: het

gebracht in een pamflet, gedrukt in 1823. De getallen geven de boetes aan in shillings (s) en pence (d).

'Any spinner with his window open

Any spinner found dirty at his work

Any spinner found washing himself

Any spinner leaving his oil can out its place

Any spinner repairing his drum banding

with his gas lighted

Any spinner slipping with his gas lighted

Any spinner putting his gas out too soon

Any spinner spinning with gaslight

too long in the morning

Any spinner having his lights too large for each light

Any spinner heard whistling

Any spinner having hard ends hanging on his weights

Any spinner having hard ends on carriage band

Any spinner being five minutes after last bell rings

Any spinner having roller laps,

no more than two draws for each roller lap

Any spinner going further than the roving-room door

when fetching rovings

Any spinner being sick and cannot find another spinner

to give satisfaction must pay for steam per day

Any spinner found im another's wheel gate

Any spinner neglecting to send his sweepings

three mornings in the week

Any spinner having a little waste on his spindles

$\begin{array}{ll}s & d \\ 1 & 0 \\ 1 & 0 \\ 1 & 0 \\ 1 & 0\end{array}$

d

2

0

20

10

20

10

10

$0 \quad 6$

10

10

$0 \quad 6$

1

0

$6 \quad 0$

10

10

10

In het pamflet staat ook dat in deze spinnerij dertien uur per dag wordt gewerkt, met gesloten deuren tijdens de werkuren, en dat het de spinners niet geoorloofd is water te drinken en dat zelfs het regenwater buiten hun bereik wordt gehouden (Hammond \& Hammond, 1.957: 32-3).

43 Waarbij wordt aangetekend dat het vreemd is dat Merchant onder deze categorie niet ook de geboden lat valien. Behavorial constraints zouden niet alleen verboden dienen te zijn, maar ook alle bepalingen en akties die bevorderen en verzekeren dat de dingen worden gedaan die moeten worden gedaan: niet alleen de gij-zult-niet's, maar ook de gij-zult's. 
was arbeiders slechts bij uitzondering gegund zelf werkplannen op te stellen of daarin mee te denken. Bij geschoolde krachten ligt dat anders. Vooral in de beginjaren van modeme fabrieken beschikten vakarbeiders over meer planningsdeskundigheid dan de entrepreneur.

Action accountability - holding employees accountable for their actions' speelde wèl een belangrijke rol. Merchant onderscheidt drie stappen in beheersing via het laten verantwoorden van aktiviteiten. Eerst definieert men welke acties gewenst of acceptabel zijn en welke niet, vervolgens kijkt men naar wat feitelijk op de werkvloer gebeurt, waarna afwijkingen worden beloond of bestraft. ${ }^{44}$ Het kijken naar het werkvloergedrag zou men kunnen scheiden in gedurige en incidentele controle. Gedurige controle is ononderbroken supervisie, bijvoorbeeld, met behulp van camera's of een altijd aanwezige voorman; incidentele controle kan plaatsvinden via inspecties en steekproeven.

Redundancy betekent het dubbel bezetten van bepaalde posities. Dit wordt vooral gedaan bij vitale plaatsen in het produktieproces. In tegenstelling tot huidige high-tech bedrijven is deze dure beheersingsvorm in het fabrieksregime nauwelijks toegepast. Bovendien is redundancy eerder een structuuraspect dan een beheersingsinstrument (Kunst, 1989b).

Personnel controls is de derde vorm van beheersing. Hiermee wil de organisatieleiding de kansen bevorderen dat werknemers de gewenste attitude aannemen en daarmee het gewenste gedrag vertonen. Met personeelsbeheersing zoekt de leiding zowel de sociale controle als individuele zelfcontrole van arbeiders te verhogen. Het tweede verwijst naar intrinsieke motivatie: óók zonder resultaten- en aktiviteitenbeheersing en sociale controle wordt het gewenste gedrag vertoond. Bedrijfsloyaliteit is er uit innerlijke overtuiging.

De gewenste attitude kan worden vergroot met: 1) selectie en plaatsing; 2) opleiding; 3) culturele beheersing; 4) groepsgewijze beloning; en 5) het aanreiken van benodigde middelen. De eerste twee spreken voor zich: door de geschikte persoon aan te nemen, op de juiste plaats te zetten en een adequate opleiding aan te bieden, wordt de kans groter dat deze werknemer de gewenste instelling zal vertonen. Hetzelfde kan worden bereikt door culturele beheersing uit te oefenen: het bevorderen van een gemeenschappelijke traditie en het aankweken van gedeelde normen, waar-

44 Gewenste en ongewenste acties moeten precies, objectief en duidelijk kenbaar worden gemaakt - mondeling (richtlijnen en opdrachten) of schriftelijk (bijvoorbeeld, werkkaarten en handleidingen) - zowel aan het begin van de werkverbintenis (in de vorm van een aannemingsgesprek en/of korte training), als later in de werkrelatie (in de vorm van gewijzigde of nieuwe taken en opdrachten), meent Merchant. 
den en overtuigingen. Met het toekennen van groepsgewijze beloning kan men vooral de sociale controle onder werknemers bevorderen, maar of dat een gunstig effect op de personeelsbeheersing heeft, is de vraag (Grumbkow, 1982). Bij aanreiking van benodigde middelen moet men denken aan voorzieningen, informatie en stafondersteuning bij het nemen van beslissingen. Opnieuw kan men zich afvragen of dit een beheersingsvorm is. Kunst (1989b) rekent 5) tot het domein van de noodzakelijke voorwaarden om tot beheersing - niet alleen personeelsbeheersing - te kunnen komen.

Op termijn zijn resultaten- en aktiviteitenbeheersing ook vormen van personeelsbeheersing. Als men gedurende langere tijd resultaten en/of aktiviteiten beheerst, stijgen de kansen dat werknemers de gewenste attitude aannemen: de sociale controle en de individuele zelfcontrole van arbeiders zullen worden verhoogd. Charles Fombrun's definitie van beheersing legt hierop de nadruk: '[..] the various control systems of the organization can work to shape through reinforcement and feedback the desired attitudes and behaviors that are consistent with a particular strategic direction' (1984: 203; ook p. 206, bij 4).

Welke beheersingsvormen werden aangewend bij de verschillende discipline- en coördinatieproblemen in het fabrieksregime? Om het vergaren en toepassen van kennis en vaardigheden van arbeidskrachten te bevorderen, is er in de eerste plaats aktiviteitenbeheersing uitgeoefend: action accountability (de voorman keek of de te verrichten werkzaamheden naar wens werden verricht), maar ook behavorial constraints ter vermijding van gedrag dat de kwaliteit of de efficiëntie kon schaden. Ook werd er personeelsbeheersing toegepast: selectie, plaatsing en opleiding, maar ook wat culturele beheersing: kennis en vaardigheid leren zien als een waarde-in-zich. Dit laatste was vooral bij ongeschoolde arbeiders nodig.

Om schikking naar het industriële ritme te bevorderen werd eveneens aktiviteitenbeheersing toegepast; aok hier voornamelijk action accountability, en ook - méér dan bij het kwaliteits- en efficiëntieprobleem - behwrorial constraints: geboden en verboden die de benodigde bijdrage aan de gestadige produktie beoogden te waarborgen. Bijvoorbeeld: het verbod op praten, zingen of fluiten, of geschreven regels met betrekking tot schafttijden, pauzes en toiletgebruik. Ook hier werd tevens personeelsbeheersing toegepast, voornamelijk weer in de vorm van selectie, plaatsing en opleiding, en ook culturele beheersing: tempo als waarde, ofwel: leer zuinig met je tijd om te gaan.

Ter beheersing van het zedelijk gedrag op de werkvloer werd in de eerste plaats action control aangewend: erop toezien dat er geen agressieve of sexuele handelingen plaatsgrijpen. Dat gebeurde wooral in de vorm van behavorial constraints, opdat er minder aanleiding en gelegenheid werd gegeven. Maar er werd ook personeelsbeheersing aangewend: opnieuw 
selectie, plaatsing en opleiding (het laatste had dan meer het karakter van vorming) en - in belangrijker mate dan bij beheersing van het werk zelf culturele beheersing: vreedzaamheid en kuisheid als waarde.

Bij zedelijke beheersing buiten de werkvloer lag, vanwege de geringere zichtbaarheid, meer nadruk op personeelsbeheersing en daarbinnen weer op culturele beheersing: vreedzaamheid, kuisheid en (de drank!) matigheid. Aktiviteitenbeheersing werd veelal uitgeoefend via inspecties en toezicht. Fabrikanten lieten op gezette tijden hun arbeiders thuis inspecteren, bijwoorbeeld bij het innen van de huur. Effectiever was een conciërge. Deze functie werd soms uitgeoefend door een inwonende voorman of arbeider, die daarmee promotie maakte, maar sympathie bij zijn gelijken verspeelde. De verhuurde woning werd ook aangewend als werktuig van beloning of straf voor wat men op de werkvloer verrichtte: goed gedrag of een hoge produktie kon resulteren in verhuizing naar een mooiere woning; bij slecht gedrag of te lage produktie gebeurde het omgekeerde, of werd de huur opgezegd.

Om te bevorderen dat men goed samenwerkte werd in de eerste plaats aktiviteitenbeheersing toegepast: behavorial constraints, zoals verordeningen die het bemoeilijken dat er solistisch wordt gewerkt, men elkaar tegenwerkt of de verwevenheid van het produktieproces dwarsboomt. Verder is opnieuw personeelsbeheersing van groot belang. Samenwerkingsgezindheid onder arbeiders werd in eerste instantie via selectie, plaatsing en opleiding bevorderd; soms ook via groepsbeloning; en weer via culturele beheersing: samenwerken als waarde.

Samengevat: problemen van discipline en coördinatie werden door fabrikanten met beheersing van aktiviteiten en personeel aangepakt - aktiviteitenbeheersing vooral in de vorm van beperkingen en controles, personeelsbeheersing in de vorm van selecteren, plaatsen en scholen en van internalisatie van waarden. Beheersing via resultaten, werkplannen, dubbelbezetting en groepsbeloning speelden in het fabrieksregime geen belangrijke rol.

Tot slot: met sommige wervings- en behoudmiddelen werden tevens beheersingsproblemen bestreden. Bijvoorbeeld: attractieve huisvesting kon de bedrijfsbinding en daarmee de werkhouding verbeteren. Ander voorbeeld: de disciplinerende effecten van verplicht sparen konden ook vruchten afwerpen op het werkvloergedrag. 


\subsection{Problemen van werving, behoud en beheersing als dimensies}

In sommige fabrieken (cq. geindustrialiseerde landen en takken van moderne nijverheid) was het lastiger arbeid te werven en behouden dan in de andere; in sommige fabrieken (etc.) hadden fabrikanten meer moeite hun arbeiders te beheersen dan in andere. Om recht te doen aan deze zwaarteverschillen kan men de twee complexen van problemen - werving/behoud en disciplinering/coördinatie - proberen te zien als dimensies, met als polen 'klein' en 'groot' (of 'ernstig').

\section{Problemen van werving en behoud als dimensie}

In arbeidseconomische handboeken wordt de vraag naar arbeid op ondernemingsniveau gezien als bepaald door de afzet, de toegepaste produktietechniek en -organisatie samen met de kapitaalgoederenvoorraad, het loonpeil en het arbeidsaanbod op relevante deelmarkten (bv. De Galan en Van Miltenburg, 1985). Deze factoren worden in hun betekenis en relatieve gewicht bepaald door het beleid van de ondernemer. Elk van deze factoren kunnen het wervings- en behoudprobleem bemoeilijken of vergemakkelijken.

In de eerste decennia van de Industriële Revolutie nam, als vermeld, de vraag naar arbeid toe. De afzet van massaprodukten op uitdijende markten steeg. Ondanks mechanisering van belangrijke delen van het produktieproces nam de arbeidsinspanning eveneens bovenmatig toe. De werktijden waren lang - 'veel langer dan uit een oogpunt van efficiëntie verantwoord was' (Maddison, 1982: 76). ${ }^{45}$ Het loonpeil steeg wel, in de cruciale decennia, maar niet in die mate dat entrepreneurs naarstig gingen streven naar maximale substitutie door kapitaalgoederen.

Het totale arbeidsaanbod in de industrialiserende landen nam eveneens toe. Van de factoren die het macro-aanbod bepalen - demografische, sociaal-culturele en institutionele factoren, de loonvoet en de vraag naar arbeid - was vooral de genoemde bevolkingsgroei van grote invloed. ${ }^{46}$ Deze opmerkelijke versnelling was niet te danken aan een toename van

45 Pas in de jaren zestig van de negentiende eeuw werd dit ingezien en daalden de werktijden.

\$6. Daarnaast waren sociaal-culturele en institutionele factoren, zoals veranderingen in het arbeidsethos, de scholingsparticipatie, de sociale zekerheid, de mate waarin vrouwen zich op de arbeidsmarkt aanboden en wettelijke bepalingen omtrent participatie van kinderen van belang. Verder speelde ook pendelarbeid en immigratie een belangrijke rol. Doordat in de beginjaren van de Industriële Revolutie een groeiend reservoir aan arbeidskrachten bestond, waren de effecten van een stijgende vraag en loonvoet groter dan wat deze volgens de theorie zouden mogen zijn: de elasticiteit van het macro-aanbod was groter dan in tijden van minder werkloosheid. 
geboortes, want deze bleven in de Westeuropese landen tot 1870 zowat gelijk, maar aan een toegenomen gemiddelde levensverwachting dankzij een daling in voothijdige sterfte door ziekte en ondervoeding (ibid., p. 72), die weer het gevolg was van beter (en beter verdeeld) voedsel en sanitaire en medische voorzieningen (p. 75), alsmede het verminderen van oorlogsgeweld. Ook zwengelden bevolkingsgroei en industrialisering elkaar aan: "new industries needed workers, and expanding population needed new means of livelihood, aldus historicus William McNeill over het laat-achttiende-eeuwse Engeland (1976: 213). Door deze toename van de bevolkingsomvang bovenin de pyramide werd ook de opbouw evenwichtiger, zodat er méér geschoolde arbeiders beschikbaar kwamen of bleven.

Het aanbod op bepaalde deelmarkten ${ }^{47}$ - voor individuele fabrikanten veel meer relevant - was uiteraard elastischer. Deze grotere elasticiteit verklaart in belangrijke mate de positie van een onderneming op de eerste dimensie. Het belang van regionale verschillen, verschillen tussen geschoolde en ongeschoolde arbeid en tussen mannen-, vrouwen- en kinderarbeid in het arbeidsaanbod tijdens de vroege Industriële Revolutie is al onderstreept. De factoren regio, soort arbeid en geslacht definiëren de voor de fabrikanten relevante deelmarkten. ${ }^{48}$

47 Deelmarktev: aggregaties van individuele aanbieders die factoren als geslacht, leeftijd, niveau, soort arbeid, regio, arbeidstijd en geschiktheid gemeen hebben - factoren die omvang, niveau, aard en mate van inspanning van de aangeboden arbeid bepalen. Deze persoonlijke kenmerken van aanbieders vormen tevens indelingscriteria voor de arbeidsmarkt. Door te segmenteren in deelmarkten krijgt men ook een beter inzicht in die factoren.

Vergeleken met het macro-arbeidsaanbod zijn in het arbeidsaanbod op deelmarkten demografische factoren en sociaal-culturele en institutionele factoren (hier: de omvang van de beroepsbevolking en onderwijskeuze, beroepenvoorkeur en regio van vestiging) van geringere betekenis. Maar de vraag naar arbeid is op deelmarktniveau belangrijker - zij het dat er aanzienlijke vertragingen in reactie op veranderingen kunnen optreden. Het loonpeil speelt eveneens een belangrijker rol dan op macro-niveau, maar niet in die mate als de vraag. Het aanbod op deelmarkten zal dus elastischer reageren op veranderingen in de vragg dan het macro-aanbod. Vergelijking met het micro-arbeidsaanbod geeft het omgekeerde beeld. Omdat individuen (of huishoudens) worden verondersteld relevante baten (nut, inkomen, aanzien) en ofters (waaronder alternatieve mogelijkheden) te kunnen afwegen, daarbij strevend naar optimalisering van opbrengsten minus kosten, is hun elasticiteit groter dan die van deelmarktgroepen ondanks, opnieuw, de mogelijke vertragingen.

48 Omdat ook hier geen sprake was van scherp gescheiden groepen aanbieders, die geen concurrenten voor elkaar zijn, moet het begrip relatizve deelmarkten worden gebruikt (Van Voorden, 1976: 32), zodat het relatieve relevante deelmarkten wordt. Ondanks deze nuancering vindt er binnen deelmarkten natuurlijk een grotere uitwisseling plaats dan tussen deelmarkten. 
Het relatieve gewicht van factoren die het macro- en micro-aanbod bepalen, geeft aan welke factoren bij grote en welke bij kleine deelmarkten zwaarder wegen. Maar ook de varieteit in het beleid van de individuele vragers kan debet zijn aan grote verschillen in elasticiteit van vraag en aanbod van arbeid.

De deelmarkt van geschoolde arbeid was in de begintijd van de Industriele Revolutie samengesteld uit arbeiders afkomstig uit het uitbesteedsysteem, de ambachtelijke werkplaatsen, de traditionele fabrieken en 'nieuwe' arbeiders uit het nijverheidsonderwijs. De deelmarkt van ongeschoolde arbeid uit arbeiders afkomstig uit de landbouw, de dienstensector, de bedeling of uit het 'niets' van de onopgeleide jeugd. In het algemeen was de elasticiteit van het aanbod van ongeschoolde arbeid groter dan van geschoolde arbeid. Dat bij ongeschoold werk de substitueerbaarheid door kapitaalgoederen groter is dan bij geschoold werk, betekent niet dat ongeschoolde arbeiders 'zwakker' staan op de arbeidsmarkt. Weliswaar staan aambieders met specifieke kennis en vaardigheden sterk zolang nog weinigen deze bekwaamheden machtig zijn, daar staat toch een (zij het minder zwaar wegende) zwakte tegenover: in de regel bezitten deze aanbieders geen andere specifieke kennis en vaardigheden, waardoor ze op andere deelmarkten zwakker staan.

Waar fabrikanten het konden doen met ongeschoolde arbeiders, deden ze dat; waar ze het konden doen met vrouwen en kinderen ${ }^{49}$, eveneens tenzij dat in strijd was met hum of andermans normen en waarden, met (in instituties verankerde) gewoonten of de wet.

Regionale deelmarkten waren van groot belang voor industriële entrepreneurs met het oog op de loonvoet die van gebied tot gebied kon verschillen en op minder grijpbare maar niet minder belangrijke factoren als mentaliteitsverschillen.

Naast de vraag naar arbeid en het aanbod op relevante deelmarkten waren de aanwendingsmogelijkheden van de overige attractiemiddelen (beloningssysteem, frequentie van uitbetaling, secundaire arbeidsvoorwaarden, gunsten en faciliteiten buiten de werkvloer) van belang. Zo waren sommige middelen te duur voor de verwachte baten. Daarnaast waren er sociale, culturele en wettelijke beperkingen, zoals de weerstand

49 Volgens Andrew Ure hebben kinderen scherpere ogen en vluggere handen. en kummen door hun lenigheid gemakkelijk bij alle plaatsen van de machines komen (aangehaald bij Coriat, 1980: 27). Belangrijker was hun grotere plooibaarheid: kinderen - en ook vrouwen (Bendix, 1963: 39) - zijn gezeglijker en kunnen daarom gemakkelijker worden gedisciplineerd. Nog belangrijker was dat fabrikanten zelf kinderen het vak konden leren en zo hun eigen standaarden konden verwezenlijken. McKendrick over Wedgwood: "To achieve the perfection he demanded he had to train his workmen from youth' (1966: 69). 
wan arbeiders tegen het industriele ritme, incongruentie met de normen en waarden van leidende maatschappelijke kringen en wetgeving met betrekking tot fabrieksarbeid en industriële verhoudingen en andere beperkende omgevingsfactoren, zoals gildenrestricties.

Ondanks deze beperkingen - beperkingen van de markt, beperkingen buiten de markt en ook hun eigen fysieke beperkingen - bleef er ruimte over om bij de aanpak van het wervingsprobleem accenten te leggen. Sommige fabrikanten kozen medezeggenschap als attractiemiddel boven verzekeringen; anderen meenden dat alleen het arbeidsloon van belang was; weer anderen zochten nieuwe middelen. Deze ruimte moet niet worden opgevat als een 'vrije speelruimte", want dan komt het element van 'noodzaak' onvoldoende tot zijn recht: om te overleven of succes te hebben was het nodig een vruchtbare keuze te maken of iets vruchtbaars te bedenken. Ik noem dit leggen van accenten binnen de gegeven ruimte de wervingsstijl van een fabrikant en de ruimte zelf de stijlruimte (die dan tevens voor een stijlnoodzaak stelt).

Het bovenstaande is in merendeel ook (vaak in spiegelbeeld) van toepassing op behoud van arbeid. Het zijn opnieuw de arbeidsmarktfactoren die de beslissing van arbeiders om opnieuw de externe arbeidsmarkt te betreden voor een belangrijk deel verklaren. Verder hier ook: aanwendingsbeperkingen van (i) attractiemiddelen die tevens ontmoedigend werken om de werkrelatie te verbreken, (ii) van de andere ontmoedigingsmiddelen: (dreiging met) sancties, (iv) van de (reglementair of contractueel vastgelegde) restrictiemiddelen en (v) van de bemoedigingsmiddelen (een aantal attractiemiddelen plus het kweken van bedrijfsbinding ${ }^{50}$ ). Ook bij het probleem van behoud van arbeid beschikten de fabrikanten - de beperkingen ten spijt - over een zekere ruimte waarbinnen ze accenten konden (en moesten) leggen. Ik zal hier spreken van behoudstijl.

\section{Problemen van discipline en coördinatie als dimensie}

Men kan niet zeggen dat het disciplineren en coördineren van arbeid voor de ene fabrikant een groot probleem was en voor de andere niet. Met aanpassingsproblemen aan het moderne fabrieksregime kampten alle arbeiders en met het coördineren van dergelijke grote aantallen nieuwkomers in een nieuw produktiesysteem had iedere fabrikant het moeilijk. Het probleem van discipline en coördinatie kan beter worden 'geschaald' naar wijze waarop naar oplossingen werd gezocht. Niet de zwaarte van het prom

${ }^{50}$ Dit laatste behoudmiddel kan dus ook behulpzaam zijn bij het oplossen van het tweede problemencomplex, dat hieronder wordt gedimensionaliseerd. Zoals gezegd, zal bij de behandeling van de invloed van dimensie 1 (werving en behoud) op dimensie 2 (beheersing) op deze 'dubbele werking' worden teruggekomen. 
bleem bepaalt welke plaats op deze dimensie wordt ingenomen, maar de bestrijdingsmethode. ${ }^{51}$ Daarvoor terug naar Merchant's indeling. Het probleem van discipline en coördinatie vat ik als een dimensie op door aan het ene uiterste te plaatsen: aktiviteiten- en resultatenbeheersing, en aan het andere: personeelsbeheersing.

In werkelijkheid zal geen fabrikant uitsluitend de ene of de andere beheersingsvorm hebben toegepast. Verschillende beperkingen lieten dat niet toe. Zo zijn sommige beheersingsvormen bij bepaalde produktiemethoden niet mogelijk. De polen van deze dimensie zijn hypothetische eindpunten van een continuüm aan reèle mogelijkheden. Het aantal variaties in samenstelling en gewicht van de beheersingsvormen is groot.

Samenstelling: in verschillende fabrieksafdelingen werden verschillende beheersingsvormen toegepast. In elk bedrijf zijn combinaties van beheersing mogelijk (en noodzakelijk). Interne differentiatie leidt tot meerdere beheersvormen, ofwel: een beheersingsmix (Kunst, 1990b). Gewicht: in een beheersingsmix ligt het voor de hand het meeste gewicht toe te kennen aan de beheersingsvorm toegepast bij de kernaktiviteiten. In de moderne fabriek is dat de produktie van goederen. Maar daarmee kan het probleem worden verplaatst: op de produktie-afdelingen waren vaak verschillende vormen van beheersing mogelijk en noodzakelijk, zoals in de fabrieken van Regout.

Net als bij de eerste dimensie kunnen meerdere factoren de positie op het continuum beïnvloeden. Zo spelen (opnieuw) een belangrijke rol: omgevingsfactoren (sociale, culturele, politieke en wettelijke beperkingen aangaande het disciplineren en coördineren van arbeid), weerstanden binnen de fabrieksmuren (uit onvermogen of onwil), verschillende gradaties van produktiecontinuiteit, eigenaardigheden van het produktieproces, die in belangrijke mate afhankelijk zijn van het vervaardigde produkt, speciale vereisten van kapitaalgoederen, kosten van verschillende beheersingsvormen en -mixen en het verwachte rendement ervan.

In hoofdstuk 5 wordt op de eigenaardigheden van het produkt aardewerk en de erbij aangewende kapitaalgoederen ingegaan. Hier worden twee andere factoren nader behandeld: a) de zwaarte van het probleem van werving en behoud (dimensie 1) en: b) de gekozen organisatiestructuur.

a) Hierboven is aangevoerd dat wervings- en behoudmiddelen ook een positief effect konden hebben op de beheersing van arbeid. Meer in het

51 Verderop zal het argument worden gelanceerd dat juist door de nieuwheid van deze beheersingsproblemen de stijlruimte groter was dan bij de wervings- en behoudproblemen en daarmee de beheersstijl van groter gewicht. 
algemeen kan men zich afvragen welke consequenties de wijze waarop arbeid werd geworven en behouden, had voor de anpak van het beheersingsprobleem. Een causaal verband tussen beide is moeilijk woorstelbaar. De zwaarte van het wervings- en behoudprobleem had geen direkte invloed op de samenstelling van de beheersingsmix. Om inzicht te krijgen hoe de beinvloeding verloopt, moet worden onderscheiden naar de relevante deelmarkten. Onder de aannames dat (i) in het fabrieksregime zowel geschoolde als ongeschoolde ${ }^{52}$ arbeid nodig was en (ii) de problemen van werving en behoud op verschillende manieren konden worden bestreden, zal men bij een aambodtekort van geschoolde en ongeschoolde arbeid attractiemiddelen aanwenden of zoeken naar alternatieven. Bij een aanbodtekort van geschoolde, maar een aanbodoverschot van ongeschoolde arbeid zal men gaan scholen. Bij het omgekeerde kan men geschoolde arbeiders gaan onderbenutten. Over deze opties kan worden opgemerkt dat: i) scholen een vorm van personeelsbeheersing is (opleiding), ii) onderbenutten weinig heeft plaatsgevonden, iii) bij alternatieven in de eerste plaats moet worden gedacht aan substitutie door kapitaalgoederen, daarna aan verandering van produkt of vestigingsplaats, iv) het aanwenden van attractiemiddelen, zoals humane leiding en medezeggenschap, geen vorm

52 Er bestonden ruwweg twee categorieèn ongeschoolde arbeiders: i) zij die in het 'machine-tempo' gedeelte van het fabriekssysteem werkzaam zijn - en zich derhalve natr het industriële ritme dienden te voegen en ii) zij die doorgaans onregelmatige, doorgaans zware 'mens-tempo' werkzaamheden moesten verrichten en, meent Thompson (1980: 473), beter niét tot het industriële ritme konden worden gedisciplineerd. De ongeschoolde 'mens-tempo'-arbeiders vormden een bijzondere categorie. 'The heavy manual occupations at the base of industrial society required a spend-thrift expense of sheer physical energy' (ibid.). Dezen moesten niet terugschrikken voor zeer zwaar en soms ook zeer vies werk.

Ook geschoolde arbeid laat zich onderverdelen in geschoolde 'machinetempo' - en geschoolde 'mens-tempo'-arbeiders.

In de aardewerkindustrie krijgt men dan deze vierdeling:

\begin{tabular}{|l|l|l|}
\hline & Mens-tempo & Machine-tempo \\
\hline Geschoold & decorateur & garneerder \\
\hline Ongeschoold & kwartsbreker & bordenstanser \\
\hline
\end{tabular}


wan doelbewuste culturele beheersing is, maar wel een nadruk op personeelsbeheersing kan bevorderen.

Men kan dus stellen dat slechts bij een aanbodtekort van geschoolde arbeid, maar niet aan ongeschoolde arbeid, fabrikanten een reden hebben (bovenop eventuele andere redenen) om aan personeelsbeheersing de voorkeur te geven boven de andere twee beheersingsvormen. En dat misschien het aanwenden van de attractiemiddelen humane leiding en medezeggenschap een hogere waarschijnlijkheid van aanwending van personeelsbeheersing (in het bijzonder van culturele beheersing) impliceert.

Als zowel de geschoolde als ongeschoolde arbeidskrachten de werkrelatie willen verbreken, kunnen fabrikanten (alsnog) ontmoedigings-, restrictie- en bemoedigingsmiddelen aanwenden. ${ }^{53}$ En als de geschoolde arbeidskrachten de werkrelatie willen beëindigen, maar de ongeschoolde niet, bestaat er voor fabrikanten tevens de optie van alsnog te scholen; in het omgekeerde geval van alsnog te gaan onderbenutten.

Samengevat: als fabrikanten arbeidskrachten ervan willen weerhouden de werkrelatie te beëindigen, staan hun diverse opties ter beschikking, waarvan sommige een invloed (kunnen) hebben op de nadruk die er in de beheersingsmix ligt. De aanwending van de attractiemiddelen (en tevens bemoedigingsmiddelen) humane leiding en medezeggenschap kunnen personeelsbeheersing bevorderen, met name culturele beheersing. De aanwending van het bemoedigingsmiddel aankweken van bedrijfsbinding komt overeen met culturele beheersing, al dienen ze oorspronkelijk een ander doel. Het alsnog scholen van ongeschoolde arbeidskrachten, ten slotte, is eveneens een vorm van personeelsbeheersing: opleiding. Van deze drie middelen lijkt het middelste - aankweken van bedrijfsbinding - de belangrijkste invloed wit te oefenen op de samenstelling van en klemtonen in de beheersingsmix.

b) In The Strucluring of Organizations (1979) heeft de Canadese organisatiedeskundige Henry Mintzberg een typologie van organisatiestructuren ontworpen. Hij onderscheidt vijf (later zes) configuraties, naar gelang een

53 Met het oog op consequenties voor de aanpak van het beheersingsprobleem noet hier, om dezelfde reden, weer humane leiding en medezeggenschap worden genoemd.

Omdat met het aankweken van bedrijfsbinding hetzelfde wordt beijverd als met culturele beheersing (zij het met een ander doel) kan het eerste een dubbel effect hebben: beheersing èn behoud. Dat kan een doelbewuste strategie zijn, maar het één kan ook een onbedoeld (maar niet onwelkom) effect zijn van het ander. Omgekeerd kan culturele beheersing als neveneffect behoud van arbeidskrachten hebben. Ook is het denkbaar dat fabrikanten bedrijfsbinding aankweken zonder dat ze een duidelijk onderscheid kunnen maken tussen beide doelen. 
aantal onderscheidende kenmerken, zoals de sleutelpartij binnen de organisatie ${ }^{54}$, het belangrijkste coördinatiemechanisme ${ }^{55}$ en diverse andere parameters. De vijf configuraties zijn: de simpele structuur, de divisionele structuur, de machine-bureaucratie, de adhocratie en de professionele bureaucratie (als zesde is daar de missionaire organisatie bijgekomen). ${ }^{56}$

In vroeg-moderne fabrieksregimes werden de volgende configuraties aangetroffen: de simpele structuur en de tussenvorm tussen simpele en machine-bureaucratie. Normaal doorlopen massaproduktie-organisaties deze stadia in deze volgorde: simpele structuur $\rightarrow$ tussenvorm $\rightarrow$ machine-bureaucratie. Dat wil zeggen dat in vroege fabrieksregimes er een tendens bestond dat de strategische top (de fabrikant) als sleutelpartij werd opgevolgd door de voorbereidende staf die het produktieproces reguleerde en dat als belangrijkste coördinatiemechanisme de directe supervisie werd vervangen door standaardisatie van werkzaamheden.

Kunst et al. (1989a) hebben Mintzberg"s structuurtypologie en Merchant's beheersingsindeling naast elkaar gezet. Zowel voor de simpele structuur als de machine-bureaucratie zien Kunst $e t$ al. aktiviteitenbeheersing als het kenmerkende beheersingsinstrument. $\mathrm{Zij}$ voegen hier aan toe een ideaaltypische voorstelling van zaken te schetsen. Ik heb aannemelijk willen maken dat het fabrieksregime zich kenmerkt door zowel beheersing van aktiviteiten (en resultaten) als personeelsbeheersing. Maar het lijkt wèl redelijk te veronderstellen dat met een toename van standaardisatie van werkzaamheden de beheersing van aktiviteiten aan gewicht zal inboeten: minder action accountability ${ }^{57}$ en minder behavorial constraints. ${ }^{58}$ Men

54 De strategische top, het middelmanagement, de voorbereidende staf, de ondersteunende staf of de medewerkers op de werkwloer.

55 Respectievelijk: directe supervisie, standaardisatie van outputs, standaardisatie van werkzaamheden, onderlinge overeenstemming en standaardisatie van vaardigheden.

56 In Mintzberg over Management. De wereld wan onze organisaties $(1991 ; 1989)$ heeft Mintzberg zijn zesdeling nogmaals tegen het licht gehouden. Zijn conclusie: zujn typologie was te statisch. Dat organisaties zich voortdurend ontwikkelen kwam te weinig tot uitdrukking. Daarom spreekt hij nu niet langer van typen of configuraties van organisatiestructuren, maar van krachten: trends in bepaalde richtingen (1991: 256-302). Hoewel dynamisering van typologieën altijd kan worden begroet, is het voor de gedachtengang hier niet nodig de nieuwe terminologie te hanteren. Daarbij komt dat de oude namen vooralsnog vertrouwder klinken.

57 De voorman hoeft niet meer zo vaak te kijken of de taken naar wens worden verricht: van gedurige naar incidentele controle. 
kan ook zeggen dat het beheersingsprobleem in de overgang van een simpele structuur naar een machine-bureaucratie meer en meer in de sfeer van het ontwerp (design) wordt opgelost - anders: dat er reeds in de structuur een oplossing wordt gezocht, want Mintzberg beschouwt design terecht als een onderdeel van de organisatiestructuur (zie opnieuw Kunst et al., 1989: 3).

\subsection{Stijlen van werving, behoud en beheersing van arbeid}

Bij het aanwenden van attractie-, ontmoedigings- en bemoedigingsmiddelen, de samenstelling van de beheersingsmix en het leggen van klemtonen daarbinnen hadden fabrikanten - ondanks de onderhand bekende beperkingen - een zekere keuzevrijheid die hen ruimte gaf voor een bepaalde stij $^{59}$ van werven, behouden en beheersen. Deze ruimte mag, zoals reeds gewaarschuwd, niêt worden gezien als een "vrije speelruimte": de noodzaak een adequate keuze te maken zou onvoldoende tot zijn recht komen. Vandaar het neologisme 'stijlnoodzaak'.

Naarmate iemands werkzaamheden rijker en ruimer zijn - en dat was het werk van fabrikanten natuurlijk in hoge mate - zijn de mogelijkheden (en de noodzaak) groter dat werk 'met behulp van" een bepaalde stijl goed

${ }^{58}$ Er bestaat minder gelegenheid tot het verrichten van acties die de constante $k$ waliteit van het werk of de produkten schaden. Standaardisatie van werkzaamheden kan men, met enige fantasie, al als een vorm van gedragsbeperking zien.

${ }^{59}$ Waar de ruimte groter is, wint het begrip stijl aan relevantie ter beschrijving van dat gebied en daarmee aan verklaringskracht. Stijl is geen restcategorie, maar een onvervreemdbaar onderdeel in de hele wervings-, behoud- en beheersproblematiek.

Een tweedeling die Mintzberg in navolging van Charles Darwin met betrekking tot managers heeft gemaakt is die tussen 'klonteraars' (lumpers) en 'splitsers' (splitters). 'Klonteraars categoriseren; het zijn synthetiseerders, met een voorliefde voor samenhangen. [..] Voor "managementklonteraars" zijn strategieën algemeen geldend, structuren types en hebben managers een bepaalde stijl". Maar "ISlplitsers muanceren; het zijn analytici, met een voorliefde voor verschillen. Omdat er nooit iets te categoriseren valt, kan niets als afgedaan worden beschouwd. Voor "managementsplitsers" lopen strategieën, structuren en stijlen eindeloos uiteen' (1991: 257). Het hebben van een stijl wordt hier voorbehouden aan de klonteraars. Maar het nuanceren en analyseren van de splitsers kan men eveneens beschouwen als een bepaalde stijl van managen. Het lijkt me onjuist om het begrip 'stijl' voor te behouden aan bepaalde stijlen, te weten de meer 'holisti-

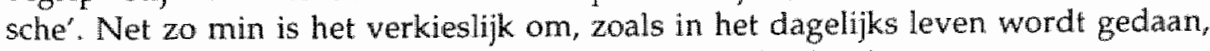
'stijl' slechts te associëren met 'smaak", "flair', "savoir-vivre', enz. 
te verrichten. Hoe gedifferentieerder iemands opdracht hoe beter stipl daaraan harmonie en cohesie kan en moet geven.

Volgens de Britse organisatiedeskundige Robert W. Witkin (1987) wordt in de organisatieliteratuur wèl ruim aandacht geschonken aan de "subjectieve', 'menselijke' aspecten van werk 60 , maar niet aan de aspecten 'stijl' en 'expressie'. Werkstijlen worden beschouwd als iets persoonlijks, aldus Witkin, iets idiosyncratisch, dat de wielen van functionele interactie in de organisatie kan smeren, maar zelf geen determinante van die interactie is.

Witkin beperkt zich tot werkstijlen, maar wat hij zegt is ook verhelderend voor wervings-, behoud en beheersstijlen. In de organisatieliteratuur, stelt hij nogal boud, overheerst het perspectief van de organisatie als een 'rational-technical machinery", waarin het werkproces op instrumentele wijze is gestructureerd ten einde gestelde doelen te bereiken. In dit perspectief wordt vaak voorbij gegaan aan de opdracht waarvoor de organisatie zich voortdurend ziet gesteld om, binnen dat gestructureerde werkproces, als een dynamisch organisme onophoudelijk zich te herscheppen. Voor deze gedurige creatieve reproduktie kan men 'stijl' gebruiken, want het werk wordt verricht door mensen die elkaar op bepaalde manieren tegemoet treden en aan hun acties een specifieke gestalte geven.

Witkin: 'A style of action is just a sensuous realisation of common values' (ibid., p. 2). ${ }^{61} \mathrm{Bij}$ het structureren van acties in organisaties wordt een verscheidenheid van belangen bij elkaar gebracht, en daarin dient door waarden die deze belangen gemeenschappelijk hebben, een eenheid te worden gecreëerd. Als stijl de realisatie of expressie van waarden is, kan men stijl voor een belangrijk deel begrijpen uit die waarden. Verschillen in stijl weerspiegelen dan verschillende waarden. Voor Witkin geldt dan ook dat "[..] a true change of style represents a shift in the foundations of common value [..]' (ibid., p. 17) ${ }^{62}$ Het zijn echter niet de waarden an sich

60 Witkin noemt onder andere Argyris Integrating the Individual and the Occupation uit 1964 en Herzberg's artikel 'One More Time: How Do You Motivate Employees?" uit 1968.

61 Over dit 'sensuous' schrijft Witkin verderop: '[..] there is an intimate connection between the sensuous qualities of action and the structure or "form" of the action itself, that is, the kind of action that takes place. The very language used, its texture and nuances, the quality of gesture and expression, all are intimately bound up with the patterning of action and, all together, they constitute its style" (p. 16).

${ }^{62}$ Handboekdefinities zijn vrij van de aandrang tot originaliteit. Een bruikbare definitie van 'waarde' geeft Robin Williams: 'An idea shared by members of a society about what is good and bad, right and wrong, desirable and undesirable. Values are general, abstract ideas that shape the ideals and goals of a society. Values are usually emotionally charged and provide the basis of justification for 
die stijlacties genereren, maar de steeds variërende vraagkenmerken van specifieke situaties: '[..] such styles may be seen as generated in response to the "demand characteristics" of particular situations" (ibid.). ${ }^{63}$

De musicoloog Leonard B. Meyer definieert stijl in zijn essay Towards a Theory of Style' als: '[..] a replication of patterning, whether in human behavior or in the artifacts produced by human behavior, that results from a series of choices made within some set of constraints' (in: Lang, et al., 1987: 21). In plaats van op waarden ligt de nadruk op keuzen. Het een

a person's behavior" (in: Popenoe, 1986: 57). Uit hetzelfde handboek komt deze definitie van 'cultuur' die op de vorige aansluit: 'The system of values and meanings shared by a group or society, including the embodiment of those values and meanings in material objects' (p. 52).

Cultuur als een systeem van gedeelde betekenissen herkent men bij de Britse socioloog Anthony Giddens (1979). Cultuur als een systeem van gedeelde waarden (en niet een verzameling geisoleerde waarden) herkent men bij Clifford Geerliz (1973). Geert Hotstede definieert cultuur als 'the collective programming of the mind which distinguishes the members of one group or category from another' (1991: 5). Aangezien hij waarden als 'the core of culture' (ibid., p. 8) beschouwt en definieert als broad tendencies to prefer certain states of affairs over other's lijkt ook bij hem dezelfde verhouding tussen cultuur en waarden te kunnen worden herkend - temeer daar nationale culturen kunnen worden gekenmerkt aan de hand van scores op waardendimensies. Hofstede vräagt ook aandacht voor de vroege internalisatie van waarden: "Values are among the first things children learn - not consciously, but implicitly. Development psychologists believe that by the age of 10 , most children have their basic value system firmly in place, and after that age, changes are difficult to make' (ibid:; zie ook Parsons, 1951: 208). Volgens deze zelfde Talcott Parsons resulteert een specifiek gedragspatroon in een samenleving uit de daar vigerende waarden. In 1906 al keerde William G. Sumner de relatie on: waarden zijn bedachte abstracte achteraf-verklaringen. Ze moeten gegroeide gewoonten rechtvaardigen, wellicht ook het irrationele karakter van sommige gewoonten verbloemen. In extremo zijn beide standpunten eenzijdig. Eerder dan te zoeken naar causale relaties tussen waarden en praktijken (in deze: gedrag, gewoonten) lijkt het zinniger te speuren naar de dialek tische reproductie van beide.

Door cultuur op te valten als een uniek samenstel van waarden en praktijken, wordt het mogelijk te spreken van specifieke culturen, zoals nationale culturen, beroepsculturen en organisatieculturen. Een samenstel van waarden en praktijken draagt ook de mogelijkheid in zich van tegenstrijdigheid, onverenigbaarheid zelfs, en - in mildere vorm - van ambiguiteit.

63 Waarbij Witkin opmerkt dat specifieke situaties, of wel problemen, nooit als geisoleerd mogen worden opgevat. Ze vormen een onderdeel van een complex problemen dat zelfs de grenzen van de organisatie kan overschrijden. Andersom geformuleerd: "[..] problems inherent in the overall structure of an organisation are apt to reproduce themselves in a variety of different guises at the level of particular action situations' (ibid.). 
hoeft het ander niet uit te sluiten: in het maken van keuzen laten mensen zich in belangrijke mate leiden door waarden, in het zich-eigen-maken en ontwikkelen van waarden door de keuzen die voor hen open staan. Daarom al vullen beide definities elkaar aan.

'Replication' wind ik minder gelukkig. Stijlacties zijn niet simpelweg replica's, maar manifestaties van voortdurende herschepping. Ofwel: aktieve herhaling. Patronen van stilistische actie verlopen automatisch noch mechanisch; zij zijn altijd problematisch. Kennis en vaardigheden, bijwoorbeeld, moet men telkens opnieuw aanwenden, maar worden bij non-routine werk nooit op exact dezelfde manier aangesproken. Men kan het werk van veel schilders meteen herkennen aan hun stijl - bepaalde thema"s, vormen, kleuren komen steeds terug - maar men kan niet zeggen dat alle schilderijen van die kunstenaar identiek zijn. En net zoals het werk van een kunstenaar bepaalde unieke kenmerken heeft, maar tevens kenmerken van de stijl van een groep, stroming, land of tijdvak, zo geldt dat ook voor actoren in organisaties. Witkin: "the personal styles of members of an organisation contain elements unique to them as well as consistencies of a wider organisational kind' (ibid., p. 5).

Samengevat: bij het doen van keuzen - het leggen van accenten - binnen een bepaalde stijlruimte wordt gebruik gemaakt van cq. teruggegrepen op kennis, vaardigheden en waarden ${ }^{64}$ - welke drie wèl kunnen worden onderscheiden, maar niet gescheiden. Hier ben ik in het bijzonder geinteresseerd in de waarden. (Voor de 'plaats" van waarden vis-à-vis praktijken in nationale en organisatie-culturen bij Hofstede, 1991, hoofdstuk 1).

Aangezien in de begintijd van de industrialisering fabrikanten nog weinig kennis en vaardigheden hadden ontwikkeld betreffende werving, behoud en beheersing, werd, juist in de stijlruimte, in grote mate een leidraad gezocht bij vigerende waarden. Waarden, in hun aard abstract, moeten echter, om bij het oplossen van specifieke problemen van nut en betekenis te kunnen zijn, reeds vaker ermee 'in aanraking" zijn geweest. Er moet een stilistische praxis van situatiespecifiek waardegebruik zijn ontstaan, willen nieuwe generaties of andere nieuwkomers waarden, die ze abstract in thun hoofd hebben, op concrete problemen kunnen "toepassen".

Voor de problemen van het fabrieksregime bestonden niet alleen geen genetisch geprogrammeerde oplossingen, er waren ook geen in de sociale ervaring ontwikkelde en doorgegeven culturele richtlijnen voor ontwik-

64 Hieruit zou men kunnen beargumenteren dat iemands stijl een "persoonlijk variatie op een cultureel thema' is (C.). Lammers, persoonlijke mededeling). Ik vind deze formulering te weinig recht doen aan de ècht creatieve vernieuwers. 'Gebruik maken van' biedt meer ruimte voor - al dan niet destructieve - creativiteit dan 'variatie'. 
keld. $^{65}$ De waarden die fabrikanten "voorhanden" waren, hadden ten aanzien deze problemen nog geen praktische traditie ontwikkeld, om het maar zo voluntaristisch te stellen. Door deze afwezigheid van een stilistische praxis terzake worden oplossingen voor de problemen van werving, behoud en beheersing gekenmerkt door ambiguiteit: die van het zoeken naar een herkenbare, consistente wervings-, behoud- en beheersstijl.

stijl reduceert de ambiguiteit, maar op de korte termijn kan het vóorkomen dat deze slechts toeneemt. In de ontwikkeling van een stilistische praxis kan het abstracte karakter van de waarden nog de overhand hebben. In een nieuw maatschappelijk bestel met nieuwe problemen kunnen abstracte waarden als vrijheid, gelijkheid en broederschap aangewend bij de oplossing van die nieuwe, maar zeer concrete problemen een averechts effect sorteren. Omdat de situatiegebonden praxis nog nauwelijks tot ontwikkeling is gekomen, zal de abstractie - dat wil zeggen: algemeenheid zich nog slecht verdragen met de verscheidenheid van de problemen. Door op alle concrete problemen eén en hetzelfde idee los te laten, neemt, met name voor anderen, de indruk van willekeur slechts toe. Deze indruk wordt nog versterkt doordat het hier gaat om akties in de "vrije ruimte", buiten de veel dwingender lijkende restricties. Ook hier voert alle consequentie tot de duivel van de willekeur. Pas als er een situatiespecifieke stilistische praxis is ontwikkeld zakt de consequentie tot een acceptabel niveau.

In de inleiding van dit boek is gezegd dat wat eerder aktieve industriële entrepreneurs al hadden ontwikkeld in hel management van het fabrieksregime i) uit angst en behoudzucht niet meteen werd overgenomen of ii) niet terstond beschikbaar was. Daar komt nog bij dat de variëteit van de nieuwe problemen van het fabrieksregime stelde zó groot was, dat eenvoudig imiteren van wat anderen aan situatiespecifieke stilististische praktijken hadden ontwikkeld, onwoldoende soelaas bood. Daarom dienden ook de fabrikanten van de tweede generatie of van het continent 'te rade te gaan' bij waarden - waarden met de potentie wan praktische toepassing.

65 Al merkt de economisch-historicus Günther Schulz op: '[..] many owners of the new industrial factories came from families of tradesmen, manufacturers and craftsmen and assumed pre-industrial commercial traditions from their fathers. That was the broadest gate for patriarchialism to enter into industrialization, where it became permanent as a social habit (Schulz, 1990: 65; zie ook Kocka, Unternehwer in der deutschen Industrialisierung. Göttingen, 1975: 133-140), het neemt niet weg dat deze patriarchialistische tradities moesten worden vertaald naar de nieuwe eisen van het fabrieksregime. Hetzelfde gold voor andere overgenomen tradities. 
Deze waarden ${ }^{66}$ waren ingebed in de dominante wereldbeelden van die tijal.

Drie dominante wereldbeelden van de negentiende eeuw

In de politieke hoofdstromingen die in regeringen en parlementen van een nog groelend aantal landen zijn vertegenwoordigd, herkent men de dominante Europese negentiende-eeuwse ideologieën: liberalisme, conservatisme en socialisme. In deze ideologieën worden op verschillende menselijke bindingen de nadruk gelegd. Het liberalisme op bindingen gebaseerd op eigembelang en contract; het conservatisme op bindingen gebaseerd op traditie en consensus; het socialisme op bindingen gebaseerd op economische dwang (Goudsblom, 1974: 123).

Het liberalisme is de oudste van de drie. Zijn uitgangspunt is '[..] het beeld van de mens als een met rede begaafd individu, in staat zijn aangeboren talenten te ontplooien en door arbeid bezit te verwerven' (ibid., p. 135). Onder deze aanname van de menselijke mogelijkheid tot het ontplooien van talenten en verwerven van bezit, "zullen de mensen tot de meest ideale en harmonieuze samenleving komen, wanneer zij vrijelijk hun welbegrepen eigenbelang kunnen nastreven, niet gehinderd door nodeloze beperkingen hun opgelegd door kerk, staat of gilde' (ibid.). Het is Adam Smith's onzichtbare hand - het mechanisme van vraag en aanbod - die uit het zelfzuchtige streven van individuen gemeenschappelijke eendracht, welvaart en geluk doet resulteren.

Een individu dat de liberale ideologie aanhangt, zal dit voor zichzelf geldig achten en voor alle andere individuen. Een liberale negentiendeeeuwse fabrikant zal dit uitgangspunt zowel op zichzelf te betrekken als op zijn arbeiders.

In de conservatieve en socialistische ideologie wordt het vrij handelende individu van het liberale mensbeeld 'als een fictie ontmaskerd' (ibid., p. 138). Het socialisme, met zijn nadruk op machts- en geweldbindingen tussen mensen, stelt dat mensen van kindsbeen af deel uitmaken van hiërarchische structuren van eigendomsverhoudingen; en hun positie binnen deze structuren bepalt voor een belangrijk deel wat zij als eigenbelang zien en welke kansen zij hebben dit eigenbelang na te streven. Evenals de liberalen zagen de socialisten economische verhoudingen - de organisatie van kapitaal en arbeid - als motor van maatschappelijke ontwikkelingen,

66 Burgerlijke en aristocratische waarden, natururlijk. Dat de lagere klassen . leveranciers van de factor arbeid - een gedeeltelijk ander waardenpatroon had. den, is een belangrik gegeven voor problemen van mee- en tegenwerking in het fabrieksregime. Bij de initiële werf-, behoud- en beheersakties van fabrikanten speelden echter vooral de burgerlijke waarden van ijver, gelijkmatigheid en zuinigheid een rol. 
maar zij interpreteerden deze verhoudingen niet als toenemende vrijheid, maar als toenemende onderdrukking - van arbeiders, maar ook van fabrikanten. Een onderdrukking die, ver genoeg voortgeschreden, een kritische massa aan vervreemding zou vormen; daarom droeg het kapitalistische systeem de kiem van klassenstrijd en revolutie in zich. Het is niet verwonderlijk dat er maar weinig socialistische fabrikanten hebben bestaan.

Interessanter is het conservatisme. Deze ideologie is een reactie op het door velen als progressief gevoelde liberalisme en socialisme. In het conservatieve denken is consensus het fundament waarop de samenleving rust, 'het gemeenschappelijk aanvaarden door alle geledingen van een historisch gegroeide, door traditie geheiligde orde (ibid., p. 140). Conservatieve denkers meenden dat samenlevingen hun eigen orde en ontwikkeling hebben, die men mag verstoren noch verhaasten. Continuiteit is het andere trefwoord. En: gezag en gemeenschap.

Deze drie 'prototypes van maatschappijbeschouwing' (ibid., p. 142) kan men zien als antwoorden op de verwarring teweeggebracht door de Franse en Industriële Revolutie (Nisbet, 1970). Deze antwoorden werden voor het eerst geformuleerd door leden van een intellectuele voorhoede. De meeste industriële entrepreneurs hebben dit gedachtengoed hooguit overgenomen en uitgedragen. Voor fabrikanten bood het liberale of conservatieve denken in eerste instantie een antwoord op hun hoedanigheid van entrepreneur, van leidinggever aan een fabriek (vgl. Kuin, 1979). In tegenstelling tot de vrijgestelde denkers bevonden de fabrikanten zich niet in de luxueuze positie om van het ideologiseren hun hoofdbezigheid te maken. Daarom spreek ik bij fabrikanten liever van wereldbeeld dan van ideologie, hoewel een aantal van hen gedachten heeft laten schijnen over het hele landschap van de samenleving.

Ook hier moeten de grenzen niet te scherp worden getrokken. Beide wereldbeelden, voor zover door fabrikanten eigen gemaakt en uitgedragen, kunnen niet volledig van elkaar worden onderscheiden. Opnieuw kan men hier de fabrikantenwereldbeelden als een dimensie opvatten door aan de uitersten de 'purur' liberale en de 'puur' conservatieve fabrikanten te plaatsen - uitersten die eveneens hypothetisch zijn. Verder zal met name de meer pragmatische functie die deze ideologieen voor fabrikanten hadden, ertoe hebben bijgedragen dat het 'aangenomen' gedachtengoed in kwestie een mengvorm van liberale en conservatieve denkbeelden was. Maar om te spreken van een wereldbeeldenmix voert te ver. De autonomie in het maken van keuzes in normen, waarden en overtuigingen is nòg relatiever dan in het aanwenden van verschillende wervings-, behoud - en beheersingswormen. Van een weloverwogen bewuste 'rationele' keuze uit welbegrepen eigenbelang is hier door de lange periode van internalisatie nauwelijks sprake. Vandaar 'mengvorm' en niet 'mix'. 


\section{Gemeinschaft versus Gesellschaft}

Het onderscheid tussen liberale en conservatieve ideologie laat zich wat anders verduidelijken met het begrippenpaar Gemeinschaft en Gesellschaft, of: 'gemeenschap' en 'organisatie'. In deze klassieke classificatie van de Duitse socioloog Ferdinand Tönnies (1855-1936), verwoord in zijn hoofdwerk Gemeinschaft und Gesellschaft (1887, tweede druk 1912, 1963), worden twee samenlevingstypen onderscheiden. In een Gemeinschaft is er weinig arbeidsdeling, zijn alle sociale organisaties gebaseerd op verwantschap, zijn de meeste sociale relaties van langdurige, persoonlijke, emotionele aard en wordt gedrag woornamelijk gestuurd door gewoonten en tradities. Hiërarchische verhoudingen zijn er dominant, al zei Tönnies dat niet nadrukkelijk erbij. Het standaardvoorbeeld is de dorpsgemeenschap met haar traditionele saamhorigheidsgevoel.

In een Gesellschaft is de arbeidsdeling ver voortgeschreden, heeft verwantschap aan belang ingeboet en zijn andere instituties belangrijker geworden dan het gezin of de familie; in een Gesellschaft zijn sociale relaties onpersoonlijker en kortstondiger geworden en wordt gedrag meer gestuurd door de wet. Instrumentele - en marktverhoudingen zijn dominant, maar ook dat zei Tönnies niet expliciet erbij. Hier is het standaardvoorbeeld: de grote stad waar het leven doelmatig en rationeel is (Tönnies, 1963; al dan niet kritische besprekingen in alle sociologische handboeken; zie ook Nisbet, 1970: i.h.b. 73-9; en voor een korte bespreking van het belang van zijn classificatie voor de bestudering van organisaties, Lammers, 1983: 60-1).

Tönnies zag zijn tijd in het teken staan van het verdwijnen van Gemeinschaft ten gunste van Gesellschaft. Een van de belangrijkste redenen was juist de opkomst van het moderne fabriekssysteem. Tönnies (op een boer-

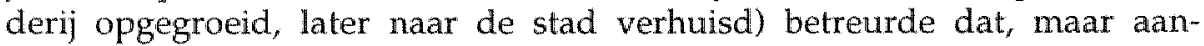
vaardde de onafwendbaarheid van deze ontwikkeling. Zijn ideaal was een op het socialisme gegronde Gesellschaft. ${ }^{67}$

Toegepast op de twee dominante fabrikantenwereldbeelden kan men simplificerend stellen: wie de Gemeinschaft als organisatiestructuur en -cultuur tot voorbeeld had, behoorde tot de aanhangers van het conservatieve denken; wie de Gesellschaft positief waardeerde, behoorde tot de aanhangers van het liberale denken.

Tönnies tweedeling doet de veelvormigheid van de sociale werkelijkheid geweld aan, luidt de teneur van de kritiek. Maar als men zijn classificatie niet rigide opvat als een statische tweedeling van volledig tegenge-

${ }^{67} \mathrm{Hij}$ was een conservatief denker, maar met een aktieve belangstelling voor het socialisme; na de opkomst van Hitler werd hij lid van de sociaal-democratische partij. 
stelde samenlevingstypen is Gemeinschaft-Gesellschaft een vruchtbaar onderscheid dat attendeert op verschillen in nadruk.

\subsection{Twee ideaaltypen ${ }^{68}$ van wervings", behoud- en beheersingsstij- len: de paternalistische ${ }^{69}$ en de liberale stijl}

Na aftrek van de beperkingen van de markt, de technische, sociale, institutionele en wettelijke beperkingen en de fysieke beperkingen van entrepreneurs in de keuze van wervings-, behoud-en beheersingsmiddelen blijft er een 'waar mogelijk' over dat kan en moet worden 'opgevuld" met 'stijl", die als paternalistisch dan wel liberaal kan worden gekarakteriseerd. Voor beheersingsstijl is die karakterisering eenvoudig te definiëren.

68 Ideaaltypen zijn (rationeel samenhangende) concepten die aandacht vragen woor bepaalde kenmerken van verschijnselen door er de nadruk op te leggen of deze zelfs te overdrijven. Een ideaaltype is een instrument waarmee een beter inzicht kan worden verkregen - in dit geval in de problematiek van arbeidsbeheersing in fabrieksregimes. Ideaal-typische constructies, bedacht ter wille van de systematiek, zijn, zoals Max Weber het uitdrukt, 'welffremd", inhoudsledig: ze corresponderen niet met enige historische werkelijkheid (1964; 14). De econoom J. 1. Klant formuleert het nog scherper: 'Het ideale type is een gedachtenconstructie ter meting en systematische karakterisering van individuele, "in hun uniciteit zinvolle", samenhangen' (Klant, 1979: 198). Het citat binnen dit citaat verwijst naar Spiethoff (1959: $450 \mathrm{ff}$ ).

Het construeren van ideaaltypen kan ontaarden in systematiek ter wille van de systematiek - met als enige leidraac de interne logica. Dit gevaar kan worden bezworen door voortdurend de dienende functie van ideallypen voor ogen te houden: het verhelderen van de ambigue, complexe, uit talloze lagen van betekenissen opgebouwde 'werkelijkheid'. Ideaaltypen zijn karikaturen. Maar als je een karikatuur van Generaal De Gaulle hebt gezien, weet je dat hij een grote neus had; bij een gewone 'werkelijkheidscongruente" foto is het niet zo zeker dat die fysiologische eigenaardigheid opvalt, hoewel het wel degelijk zo is - in vergelij. king met de gemiddelde neusgrootte had De Gaulle een bovenmaatse neus.

Behalve het gevaar voor systematiek-ter-wille-van-de-systematiek loop: men het risico dat definiërende en empirisch-beschrijvende uilspraken in elkaar gaan overlopen, zodat niet meer is te achterhalen of een bewering betrekking heeft op samenhangen in het analytische systeem of op empirisch vaststelbare samenhangen in de sociale werkelijkheid. Niettemin moeten ideaaltypen een functie te hebben in de empirische analyses. Dat is hun bestaansreden.

69 Al zijn de woorden 'conservatief' en 'paternalistisch' geen synoniemen, hier wordt ervan uitgegaan dat industriële entrepreneurs met een conservatief wereldbeeld een dispositie vertoonden tot een paternalistische wervings-, behoud- en beheersstijl. De enige reden hiervoor is dat met 'paternalistisch' beter kan worden aangesloten bij het dagelijks, historisch en sociaal-wetenschappelijk taalgebruik. 
Waar mogelijk industriële entrepreneurs een blijvende voorkeur tentoonspreidden voor een nadruk op personeelsbeheersing spreek ik van een paternalistische beheersstijl. ${ }^{70}$

Waar mogelijk industriële entrepreneurs een blijvende voorkeur tentoonspreidden voor een nadruk op aktiviteitenbeheersing (en resultatenbeheersing) spreek ik van een liberale beheersstijl.

Voor de wervings- en behoudstijl is dat moeilijker:

Waar mogelijk fabrikanten een blijvende voorkeur tentoonspreiden voor een nadruk op gemeinschaftliche middelen tot werving en behoud van arbeid spreek ilk van een paternalistische wervings-en behoudstijl.

Waar mogelijk fabrikanten een blijvende voorkeur tentoonspreiden voor een nadruk op gesellschaftliche middelen tot werving en behoud van arbeid spreek ik van een liberale wervings- en behoudstijl. ${ }^{71}$

Met gemeinschaftliche middelen worden vooral de machts- en gezagsverhoudingen, al dan niet doortrokken van het gemeenschapsideaal, bestendigd of versterkt. Men kan denken aan humane/niet-inhumane leiding, medezeggenschap, scholen, leeszalen, gebedsruimten, ontspannings- en kunstbeoefeningsverenigingen, het aankweken van bedrijfsbinding, het verplicht opbouwen van een tegoed of verplicht sparen, enzovoort.

Met gesellschaftliche middelen worden vooral instrumentele of marktgerichte arbeidsverhoudingen in tact gelaten of bevorderd. In de allereerste plaats is dat het arbeidsloon. Daarnaast kunnen ook beloningssystemen, gunstige regelingen met betrekking tot overwerk, nachtwerk en onaangenaam of risicovol werk, een goede werk-woonverkeerregeling en verschillende contractueel of reglementair vastgelegde beperkingen afhankelijk van de 'invulling', tot deze categorie worden gerekend.

70 In het gebied van het 'waar mogelijk' zal nooit uitsluitend de nadruk op, zeg, personeelsbeheersing worden gelegd. Een paternalistische stijl zal altijd liberale trekken vertonen en omgekeerd. Vandaar weer: ideaaltypen van beheersstijlen.

${ }^{71}$ Het is denkbaar dat fabrikanten een liberale wervings- en behoudstijl hebben, maar een paternalistische beheersstijl, en omgekeerd, maar niet waarschijnlijk. Dimensie 1 (het probleem van werving en behoud) is een belangrijke factor bij dimensie 2 (het probleem van disciplinering en coördinering). En wat belangrijker is: de meeste mensen kennen maar één waardenpatroon, dat de leidraad vormt voor hun waarderationaliteit (Weber, 1964; ook: Lammers, 1983: 463). 
De meeste middelen echter kan men bij beide categorieën onderbrengen: frequentie van uitbetaling, hygiënische en gezonde werkomstandigheden, vrije beschikking over gereedschappen, spaarmogelijkheden, ziekte-, ouderdoms- en ongevallenverzekeringen, bedrijfswinkels, woningbouw, het verlenen van kredieten, werkgarandering na een bepaald aantal dienstjaren en verschillende restrictiemiddelen en sancties. Zelis loon - het meest gesellschaftliche middel - kan loyaliteits- en zelfs onderdanigheidseffecten sorteren. Opnieuw doemt hier na constructie van ideaaltypen de complexiteit en ambiguiteit van de sociale 'werkelijkheid' op.

Al doet de terminologie anders vermoeden, beide stijlen zijn vormen van autocratisch leiderschap. ${ }^{72}$ Of een fabrikant paternalistisch of liberaal was, zijn leidinggeven kenmerkte zich door: -domineren, het doen gehoorzamen van volgelingen; - $d$ wang en straf op overtredingen; -boetes, ontslag en lager loon; -het temperen van initiatief, enthousiasme of verantwoordelijkheid.

72 Dat kan zelfs worden gezegd van utopistische initiatieven als die van de Britse hervormer Robert Owen: '[..] the great experiments at New Lanark were instituted to meet the same difficulties of labour discipline, aldus Thompson (1980: 858). Owen heeft zich meerdere malen beklaagd zich over het gebrek aan discipline onder zijn arbeiders. In zijn boek A New View of Societies (1813, 1927) schreef hij dat het probleem was om de jongeren thabits of attention, celerity, and order' (in: Thompson, 1980: 859) in te prenten. Maar hij koos niet voor, wat Thompson noemt, de psychische terreur van het methodisme en ook niet voor opzichters en straffen. Nietttemin hoeft er geen twijfel te bestaan over wie alle utopisch-socialistische arrangementen in New Lanark heeft bedacht en geimplementeerd. Bendix: '[.] he had more in common with the traditional conception of an aristocratic master than with the personnel manager in a modern factory" (1963: 50).

Autocratisme wordt in de organisatiejeer vaak gezien als een stadium dat aan bureaucratisch leiderschap voorafgaat. De eerste decennia van de Industriële Revolutie kan men inderdaad ook kenschetsen als prebureaucratisch. Niet zozeer ondat de praktijken van persoonlijke bevoogding, bevoordeling en straf een nog vitale rol speelden (hetgeen met name bij paternalistische entrepreneurs duidelijk kan worden geconstateerd), maar omdat de wet- en regelgeving van lokale en nationale overheden ten aanzien van fabrieksarbeid nauwelijks was ontwikkeld. Deze zou pas, mede op aandrang van de arbeidersbeweging, an het eind van de negentiende eeuw serieuze aanvang nemen - in Nederland, bijvoorbeeld, bekleedt Van Houten's kinderwetje uit 1874 de (niet onomstreden) symboolfunctie van eerste stap in de wetgeving op dat gebied. 
Beide beheersstijlen onderscheidden zich door een grote machtsongelijkheid en een vergaande uitoefening van die macht. ${ }^{73}$

In de bekende studie Industrialism and Industrial Man hebben Kerr et al. een onderscheid gemaakt tussen vier typen 'industrializing elites': de 'dynastic elites', de 'rising middle-class elites', de 'new nationalist leaders' en de 'new revolutionary intellectuals'. Hier zijn de eerste twee typen van belang. De dynastieke elites laten zich leiden door de rigide klassestructuur uit de pre-industriële tijd, maar de middenklasse-elites door democratische en egalitaire denkbeelden (1961: 47-76). Ik vrees dat Kerr et al. aangaande de negentiende-eeuwse middenklasse-elites te optimistisch zijn: verreweg de meeste burgerlijke industriëlen dachten in autocratische - voor mijn part: dynastieke - termen.

\section{Liberale en conservatieve denkbeelden aangaande arbeid}

'Peu de conceptes s'opposent, en apparence, avec une telle netteté,' schrijft Eliane Gubin in 'Libéralisme économique et paternalisme en Belgique au XIXe siècle' (in: Aerts, et.al., 1990). Het liberalisme immers is gebaseerd op de vrijheid van het individu; het paternalisme op de familierelatie, het idee van bescherming en curatele (ibid, p. 82).

Een cruciale opvatting in het liberale denken (van fabrikanten) over de produktiefactor arbeid was dat arbeiders niet hoefden te worden afgeschermd van het marktmechanisme binnen en vooral buiten de organisatie. Dat was zelfs niet wenselijk. Mensen moeten de vrijheid hebben om markten te betreden en te verlaten wanneer hen dat goeddunkt. Hen daarin te willen belemmeren is een daad van onaanwaardbare bevoogding, die indruist tegen de eerste waarde van de Franse Revolutie: vrijheid. Vragers en aanbieders van arbeiders zijn vrij om te gaan en staan waar ze willen; dat behoort tot hun eigen verantwoordelijkheden. 'Laissez faire, lassez aller, le monde va de lui mèmé.

In het conservatieve denken (van fabrikanten) aangaande arbeid luidt de overheersende opvatting dat arbeiders juist zo weinig mogelijk aan het vrije-marktmechanisme moeten worden blootgesteld. Als leden van de lagere klassen worden ze niet in staat geacht ${ }^{\text {th }}$ om hun belangen via de markt na te streven. Daarom dienen ze te worden bevoogd. Dat gaat het beste door hen van interne en externe arbeidsmarkten af te houden met een arsenaal aan middelen erop gericht de bestaande gezags- en loyali-

73 ..Een vorm wan leiderschap die zelfs niet door als wetenschappelijk geclaimde inzichten werd ontmanteld. In het scientific management, de klassieke organisatietheorie met het technisch-economisch karakter dat uitsluitend was gericht op opvoering van prestaties, bleef de grote machtsongelijkheid en de strenge sancties op schending onverminderd van kracht.

74 ..en hebben misschien het (burger)recht niet. 
teitsverhoudingen in stand te houden. Dat is de verantwoordelijkheid ${ }^{75}$ van degenen die deze verhoudingen bestendigen: de fabrikanten. De zwakkere partij moet geleid en beschermd. ${ }^{76}$

Dwang - kenmerk van beide stijlen - en conservatief denken laten zich gemakkelijk verenigen, maar hoe kan het liberale denken worden gerijmd? Eenmaal op 'Jiberale wijze' gealloceerd, moest de produktiefactor arbeid zo optimaal mogelijk worden ingezet. Er moesten taken worden verricht en dat geschiedde, zoals de bespreking van disciplineringsproblemen heeft duidelijk gemaakt, niet zonder een mate van dwang van entrepreneurs en hun agenten (voormannen, chefs), hoe hoog het arbeidsloon ook mocht zijn. Deze dualiteit laat zich verduidelijken met een variant op een Nederlands gezegde: heb je - op vrijwillige basis - eenmaal a gezegd, dan moet je ook b zeggen. Anders gezegd: in liberale fabrieksregimes werd 'slechts' dwang uitgeoefend waar het marktmechanisme zijn heilzaam geachte werking niet kon uitoefenen. ${ }^{77}$ Niettemin bestonden in het uitoefenen

75 ..en daarom het recht.

${ }^{76}$ Een paternalistisch fabrieksregime in extremo kan men, evenals gevangenissen en psychiatrische inrichtingen, beschouwen als een totale institutic (Goffman, 1961), die worden gekenschetst door vrijwel absolute controle (beheersing) en een afsluiting van de samenleving. Ook paternalistische entrepreneurs beschermen niet alleen de materiele aspecten van het leven van 'hun' arbeiders, maar ook hun gemoedsrust door bepaalde gevoelens van zekerheid en gebondenheid te cultiveren. Tegelijk ook onderdrukken zij ondermijnende vragen.

Er is al gesteld dat de verschillende fabrieksregimes niet kunnen worden gezien als organische organisaties; er loopt geen lijn van paternalistische naar excellente organisaties.

77 Deze dubbelheid tussen liberalisme, war het prijsmechanisme werkt, en 'hardvochtig' autocratisme, waar dat niet zo is, moge het volgende citaat verduidelijken: "The classic exploitive relationship of the Industrial Revolution is depersonalised, in the sense that no lingering obligations of mutuality - of paternalism or deference, or of the interests of "the Trade" - are admitted. There is no whisper of the "just" price, or of a wage justified in relation to social or moral sanctions, as opposed to the operation of free market forces. Antagonism is accepted as inirinsic to the relations of production. Managerial or supervisory functions demand the repression of all. attributes except those which further the expropriation of the maximum surplus value from labour. This is the political economy which Marx anatomized in Das Kapital. The worker has become an "instrument", or an entry among other items of cost' (Thompson, 1980: 222). Maar, woegt Thompson daar aan toe, een complexe industriële organisatie, kan niet functioneren met een dergelijke filosofie. Om de arbeidsrust te bewaren en een stabiele, kundige en ervaren werkmacht te creëren moesten de managerstechnieken worden aangepast. Zo ontstonden in Engelse katoenfabrieken rond 1830 nieuwe vormen van paternalisme. Maar waar vraag en aanbod van ongeschoold werk groot 
van dwang accentverschillen tussen liberale en paternalistische fabrikanten: nadruk op (instrumentele) aktiviteiten- en resultatenbeheersing versus nadruk op (gezags- en loyaliteitsvergrotende) personeelsbeheersing.

\section{Paternalisme}

Omdat aan het liberale denken, ook met betrekking tot arbeid, ruim aandacht is besteed ${ }^{78}$ zal in deze paragraaf een enkele aspecten van het paternalisme - als gedachtengoed en stilistische praktijk - worden gepresenteerd. Deze worden gevolgd door een paar opmerkingen over twee kenmerkende ambiguiteiten.

De adjectieven van Weber's ideaaltypische driedeling in grondwormen van heerschappij - 'traditioneel', 'charismatisch' en 'rationeel' - waren geen nieuwvormingen. Ze waren beladen met historisch gegroeide betekenissen. Bij gebruikmaking van bestaande begrippen kan aan de 'oorspronkelijke' betekenis beter niet worden voorbijgegaan: om misverstanden te voorkomen, maar ook omdat het contrast tussen 'bestaande' en 'ideaaltypische' betekenissen verhelderend kan werken.

Het Groot Woordenboek der Nederlandse Taal ("Van Dale")(Geerts, 1984) geeft als omschrijving van 'paternalisme':

"Bevoogding; het optreden van de overheid tgov. het volk, of van een overheersend volk in vreemd gebied (kolonie of vroegere kolonie) of van een gezaghebber als een vader of voogd die het goede met het volk, zijn kinderen of pupillen voorheeft, maar hun geen invloed van belang geeft op hun eigen aangelegenheden.'

Volgens deze omschrijving heeft paternalisme betrekking op meerdere menselijke bindingen: tussen regeerders en geregeerden, overheersers en overheersten, gezaghebbenden en ondergeschikten.

Onder deze laatste categorie kunnen worden gerekend: bindingen tussen degenen die in hiërarchische organisaties arbeid aanbieden en die dat aanbod accepteren.

De herkomst van het woord 'paternalisme' is gemakkelijk te traceren. 'Paternalisme' is een derivaat van het Engelse 'paternal' ('vaderlijk'). Het suffix -ism(e) verwijst naar een systeem of ideologie. "Paternal" komt van het Latijnse adjectief 'paternus', wat ook vaderlijk betekent (van 'pater', vader). 'Paternalisme' is dus afgeleid van een oudere metafoor die werd

waren, bleef de liberale managersstijl de overhand houden.

78 .mede doordat de liberale denkbeelden in brede kring zijn aanvaard als gezonde grondslag van het kapitalistische systeem, maar ook doordat een succesvolle wetenschap als de economie er zijn belangrijkste inspiratiebron in heeft gevonden. 
gebruikt om bepaalde sociale verhoudingen mee aan te duiden. 'Als een vader voor zijn kinderen': het beste voorhebbend, maar streng en niet ervan gediend commentaar of tegenspraak te krijgen. De semantiek van dit woord kan uit zijn etymologie worden begrepen: 'paternalisme' is altijd gebruikt in de letterlijke betekenis. ${ }^{79}$ De elementen waarop in deze metafoor de klemtoon wordt gelegd - autocratische bevoogding en bescherming - zijn ook als essentieel geformuleerd in de paternalistische stijl.

De oorspronkelijke en dagelijkse betekenis van "vaderlijk" is allicht even" eens van belang voor het gebruik van het woord paternalisme in de economie en sociologie. Met de morele connotaties van woorden uit de spreektaal moet rekening worden gehouden. Woorden kunnen te beladen zijn om er wetenschappelijk gebruik van te maken. Met het woord 'pater" nalisme' lijkt mij dat, in tegenstelling tot bijvoorbeeld 'civilisatie', niet het geval. Het blijft een kwestie van smaak en gevoel.

Een wetenschappelijke definitie uit de Encyclopaedia of the Social Sciences: paternalisme is the regulation or control of a person, community, or country in the manner in which a father controls his children. The paternalistic leader provides care and protection in exchange for support and obedience. There are two types of paternalistic relations. One system is primarily instrumental and often exploitative, such as that between serf and lord. Another system is of mutual benefit to both parties, such as that between master and apprentice". De dagelijkse metafoor is gehandhaafd, maar dankzij de toelichting in de tweede zin blijt het woord niet in het vage. Wat verder opvalt is dat de paradox - zorgzaam, maar streng - in deze definitie uiteenvalt in twee subtypen. ${ }^{80}$ Het kan geen kwaad onderscheid te maken in een paternalisme waarin de nadruk ligt op het zorgzame aspect en in één waarin de nadruk ligt op het dwangmatige aspect $^{81}$, maar er zal géén paternalistische stijl worden gevonden die zich

79 Zo heet de paragraaf warin de organisatledeskundige D. Horringa (1969: 147-9) paternalistische werkverhoudingen behandelt: "Kinderen van de patroon'.

${ }^{80}$ Günther Schulz onderscheidt in zijn artikel Industrial Patriachalism in Germany (in: Aerts, etal, 1990 ) bimen het patriarchalisme een patemalistische variant (die streng was, want arbeiders werden verondersteld begrip en wilskracht te missen) (p. 62) en een protectoralistische variant (die pedagogische ambities had, want arbeiders werden beschouwd als voorbijgand onrijp; ze moesten naar vrifheid en verantwoordelijkheid worden geleid) (p. 63).

$81 \mathrm{Vgl}$ de classificatie van managementsystemen van de Amerikaanse psycholoog en socioloog Rensis Likert in New Patterns of Managenent (1961: 222-234), waarin hij een onderscheid makt tussen 'explotioe authoritative" en 'bencoolent auhoritative" de twee minst produktieve systemen, met de meest wantrouwige arbeidsverhoudingen. Overigens makkt Likert geen onderscheid tussen paternalistisch en liberaal management. 
niet kenmerkte door een ambiguiteit tussen dwang en zorg. Paternalisme betekent altijd een combinatie van - in Hofstede's nationale culturdimensies (1980, 1991) - hoge machtsafstand en hoge mate van femininiteit.

Een andere ambiguiteit is al aangeroerd: die tussen motieven van welbegrepen eigenbelang en filantropische ${ }^{82}$ gevoelens en denkbeelden bij industriële entrepreneurs. Ook - misschien wel: met name - in de paternalistische stijl kunnen commerciële en menslievende motieven worden herkend. ${ }^{83}$ Schulz ontrafelt ook deze ambiguiteit. Hij onderscheidt fabrikanten i) die werden geïnspireerd door filantropische humanitaire en religieuze en ethische gevoelens - die in de beginfase van de Industriële Revolutie zouden overheersen - en ii) die louter economisch voordeel zagen: '..] it helped to recruit and bind labour force, especially highly qualified workers, to reduce fluctuation and to prevent unauthorized divulging' (1990; 65) en bovendien werd de moraal erdoor opgevijzeld en de machtsverhoudingen bekrachtigd. Voor het bestaan van dat laatste motief voerde Schulz als 'bewijsstuk' aan dat de patriarchialistische praktijken werden geadopteerd door mensen die er niet door conventie toe werden gebracht: industriële self-made men, 'technicians' en andere nieuwkomers. Conclusie: er moesten (economische) voordelen aan kleven.

Maar bij dit alles dient bedacht dat: '[..] the extent to which industrialists behaved as paternalists varied through time, between firms, between

82 Naar het waarom van beide zal hier niet worden gevraagd. Bij eigenbelang wordt die vraag zelden gesteld: een verwijzing naar de menselijke natuur volstaat. Dezelfde verwujzing kan men ook well warnemen ter verklaring van filantropie: eigenbelang op de lange termijn.

Op een minder filosofisch niveau kan men stellen dat de filantropische tradities onder de eerste stand (de adel) ten gunste van de vierde stand (het volk), die vakk werden argedwongen door de tweede stand (de geestelikheid), een positieve invloed hebben gehad op de ontwikkeling van deze tradities onder de derde stand (de burgerij). Als nieuwe aristocraten dienden de burgerlijke eliten, onder wie de succeswolle tabrikanten, dezelfde goedertierenheid jegens de lagere klasse te betrachten. In een variatie op een oude leus: Nonwelle noblesse oblige.

Dat kan de reden zijn geweest watrom Petrus Regout in een nota aan de commissie Kinderarbeid (1864) deze volgorde anhoudt

'De beoordeling dezer kwestie (van de kinderarbeid, avi) moet van twee zijden beschouwd worden

1 Uit een menschlievend oogpunt

$2^{\circ}$ In verband met het nut der nijverheid"

83 In The Chocolate Conscience (1987) geeft de publiciste Gilian Wagner een beschrijving van deze ambiguiteit bij drie succesrijke negentiende-eeuwse Britse cacaofabrikanten: Joseph Storrs Fry, George Cadbury en Joseph Rowntree. Zie ook mijn bespreking in Vrij Nederland Boekenbijlage (1988). 
industries and within industrial structure. As a result, historians have identified sharp contrasts in the motivation, scope and success of paternalist practice during and after the industrial revolution in Britain' (Rose, 1990: 115).

\subsection{Legitimering van stijl}

Omdat 'stijl' keuzevrijheid suggereert, zal bij alle betrokken partijen de behoefte groter zijn de 'gekozen' stijl te legitimeren of gelegitimeerd te zien. Hoe groter de keuzevrijheid, immers, des te groter het gevaar - en daarmee het verwijt van willekeur. Het waren niet zozeer de industriële machtsverhoudingen als zodanig die rechtvaardiging behoefden, maar het feit dat nieuwkomers (zie Bendix, 1963: 24, die William Cobbett's sneren aan het adres van 'new rich' citeert) deze macht uitoefenden en nog wel in een bepaalde stijl.

'[C]elebrating entrepreneurship', "making poverty the fault of the poor", kortom 'to weave elaborate systems of justification', (Brown, 1978: 67) dat is wat de pleitbezorgers van het fabrieksregime (en dat waren in eerste instantie de fabrikanten zelf) deden. Ze waren verwikkeld in een vestigingsstrijd op meerdere fronten ${ }^{84}$ en moesten verschillende wapenen opnemen, ter accumulatie van statuskapitaal, waarvan de meesten vooralsnog waren verstoken. Legitimering kan men zien als een vorm van "impression management' (Goffman, 1959): de pogingen om je zodanig te presenteren dat anderen je zullen zien zoals jij dat wilt. Goffman maakt onderscheid in 'front stage'- en 'back stage'-gedrag. Het eerste is bedoeld voor vreemden en bekenden met wie men niet op nauwe voet staat; het tweede geldt goede bekenden en intimi. In historisch onderzoek kan men. vrijwel uitsluitend 'front-stage' bestuderen. Slechts intieme correspondentie (en intieme herinneringen van anderen) zijn verduurzaamde vormen van buck stage'-gedrag.

Men kan legitimering ook zien in termen van produktie: als transformatie van middelen tot status. Afnemer van dat produkt is in de eerste

84 Dat wil zeggen: tegenover verschillende elites. Men kan zeggen dat aristocratisering verwijst naar het streven om de mentaliteit en leetstijl van de adel aan te nemen en naar het strewen nar duurzame connecties met geadelde elites (vgl. Bendix, 1963: 30-4, voor wat betreft de Engelse industriele entrepreneurs); dat devotionalisering verwijst naar een orientering op religieuze waarden en naar het streven naar conneclies met religieuze elites (wgl. Goudsblom, 1988: 172); en dat verburgerlijking verwijst nati een oriëtering op burgerlijke warden, zoals geld verdienen door hard werken en het primat van een harmonieus gezinsleven, en naar het streven naar connecties met burgerlijke elites (voor zover ze daar niet vandaan kwamen). 
plaats de producent zelf. Daarom is het entrepreneurschap méér dan een reeks 'economische' beslissingen alleen. Als men een holistisch perspectief op ondernemen hanteert, zijn bepaalde als irrationeel geoormerkte waarden of praktiken (bijvoorbeeld die ook op de lange termijn kostenverhogend werken) 'verklaarbaar' als logische en zinnige zetten in de vestigingsstrijd. In deze strijd kan men een 'economische' en 'sociale' strategie herkennen, welke zijn te onderscheiden, maar niet te scheilen. Wanneer met een bepaalde daad of praktijk beide doelen worden gediend, wordt er opnieuw ambiguiteit gevoeld.

Handelingen en praktijken - zoals een liberale of paternalistische stijl worden vaak gelegitimeerd door te verwijzen naar de onderliggende waarden. Zo kan werving van arbeid eenvoudig 'idealistisch' worden "verkocht' met het argument: als je mensen verleidt tot fabriekswerk hou je ze van de straat en geef je ze een boterham in de hand. En behoud van arbeid met: als je ze weet te houden, weerhoud je ze van terugval in de vroegere beklagenswaardige staat. Beheersing van arbeid, ten slotte, met het argument van opvoeden en beschaven.

Indirekt vloeit de 'achteraf-legitimering' natuurlijk eveneens voort uit waarden in de culturele context: anders zou men niet eens op het idee komen zich dusdanig te legitimeren. En men zou het ook niet met succes kunnen nastreven als de waarde van de filantropie niet in de culturele context anwezig was.

Daarbij moet de gedachte worden verlaten dat uitsluitend uit welbegrepen eigenbelang wordt gelegitimeerd. Ook hier kan weer de ambiguiteit tussen cynisme en argeloosheid (om het eens zó té formuleren) herkennen. Mensen zijn voortdurend in de weer zich te legitimeren; het mag geen verwondering wekken dat men van lieverlede in alle integriteit zelf óók erin gaat geloven.

Wie iets wil legitimeren, kan kiezen uit een aantal mogelijkheden. De eerste is: simpelweg iets uitoefenen. Aantonen dat een daad bestaansrecht heeft door hem to verrichten. Men kan ook in woord, geschrift, beeld of bouwsel naar praktijken verwijzen. Vertellen of laten vertellen, loopt het risico van vluchtigheid. Zoekt men duurzaamheid dan kan men het beter (laten) opschrijven of in ander duurzaam materiaal neerleggen: gebouwen, beelden, voorwerpen. Dat blijkt: voor de legitimeringen van fabrikanten uit de beginjaren van de Industriële Revolutie zijn we afhankelijk van wat zijzelf en anderen hebben geschreven en in artefacten neergelegd. ${ }^{85}$

Geschriften en artefacten, vervaardigd door de fabrikant zelf, of wiens aandeel in planning en uitvoering groot is geweest, kunnen nu nog in originali, 'uit de eerste hand', worden bestudeerd. Een groot aantal andere

85 Voor oral history - het optekenen van mondelinge getuigenissen - is dit alles te ver verleden tijd. 
daden daarentegen leeft eveneens slechts voort in beschrijvingen en commentaren van anderen, en in artefacten die voor het belangrijkste deel op het conto van anderen kunnen worden geschreven, zodat de onderzoeker wordt geconfronteerd met materiaal 'uit de tweede hand'. Dit schept (extra) problemen van interpretatie, zoals in het volgende hoofdstuk zal blijken. 



\section{HOOFDSTUK 5}

\section{DE STIJL VAN PETRUS REGOUT}

\subsection{Wervings-, behoud- en beheersingsstijl in de fabrieken van Petrus Regout}

De geschiedenis wordt niet gemaakt met het oog op toetsbaarheid van een achteraf geconstrueerde classificatie. Maar omgekeerd kan een ingewikkeld historisch geval worden verhelderd door er een grove classificatie tegenaan te houden. Met het onderscheid tussen een liberale en paternalistische stijl kan systematiek worden aangebracht in de beschrijving en verklaring van de historische verscheidenheid van wervings-, behoud-en beheersingsproblemen in de vroege Industriële Revolutie. In deze paragraaf geef ik enkele voorbeelden van Regout's stijl van werven, behouden en beheersen. In de paragrafen 2, 3 en 4 worden enkele aspecten verder uitgediept, waarin de ambiguïteit tussen liberale en paternalistische motieven pregnant naar voren komt: i) arbeiderswoningbouw als wervings-, behoud- en beheersingsmiddel en ii) Regout's legitimering van zijn stijl via publikaties over het pauperismevraagstuk.

Loon, beloning en uitbetaling

Zoals uit de gevalsbeschrijving in hoofdstuk 2 is gebleken, had Regout aanvankelijk ${ }^{1}$ nauwelijks problemen met de recrutering ${ }^{2}$ van ongeschool-

${ }^{1}$ Pas vanaf 1851 werd de lokroep van andere stedelijke fabrikanten gehoord: in dat jaar richtten de zout- en ziepzieder Wijnand Nicollas Clermont (een tegenstander van Regout, afkomstig uit de lokalle politiek, wan wie werd beweerd dat hii uit rancune industriële aktiviteiten ging ondernemen) en zijn gefortuneerde zwager Charles Chainaye uit het Waalse stadje Hoei een aardewerkfabriek op, aan de overkant van de Maas, de latere Société Céramique. Op 31 december 1852 werkten er 107 arbeiders, onder wie een aantal 'overlopers' uit de aardewerkfabriek van Petrus Regout, die met hogere lonen waren weggelokt (Stichting Werkgroep Industriële Archeologie Maastricht, 1989: 12). In 1855 werkten er 243 arbeiders; van toen af mag de fabriek worden beschouwd als 'in vol bedrijf'. Naar de Nederlandse normen was het van méér dan gemiddelde omvang (met een stijging naar 764 arbeiders in 1887).

$\mathrm{Na}$ een crisis in de afzet werd het bedrijf in 1859 omgezet in een commanditaire vennootschap, een belangencombinatie tussen de twee oprichters en een 
de arbeid, maar wèl met de werving van vaklieden. Dat was des te nijpender omdat hij de geschoolden ${ }^{3}$ ook nodig had om een belangrijk deel van de ongeschoolden te scholen. Met hun beroepsspecifieke kennis en vaardigheden waren zij van cruciaal belang voor het voortbestaan en de uitbouw van Regout's bedrijven. Het is goed denkbaar dat de buitenlandse vakarbeiders - bovenop de aanpassingsmoeilijkheden aan het fabrieksleven met zijn eisen aan tempo en discipline, waar ook de lokale ongeschoolden mee kampten - last hadden van heimwee. ${ }^{4}$

Het verloop onder ongeschoolde en geschoolde werklieden was groot. Voorzover in de eersten nog weinig opleidingskosten waren gestoken, was dit gezien het aanbodoverschot geen groot probleem: voor-jou-tien-anderen. Maar om de geschoolde en semi-geschoolde arbeiders te (werven en) behouden heeft Regout wèl opmerkelijke inspanningen geleverd. Het

Belgische groep financierders die vermoedelijk werden gepatroneerd door de Société Générale" (ibid., p. 13). Maar in 1863 al werd het bedrijf een NV. In 1853 trad ook de zeepzieder N.A. Bosch toe tot de lokale concurrenten. Hij begon een aardewerkfabriek. Hij startte met dertig man.

Misschien is met het toetreden van lokale concurrenten ook jets verklaard van de verbetering van de sociale voorzieningen die in de jaren vijftig en zestig bij Regout kon worden geconstateerd. Op het wegkopen van arbeiders door Clermont en Chainaye reageerde Regout in ieder geval door een hoger loon te bieden - en door tegen sommigen wegens contractbreuk een proces aan te spannen (ibid. p. $9 \& 12$ ).

Ook hebben de toetreders een prikkel tot technische vernieuwingen gegeven: 'Opvallend is, hoe in deze jaren Regout, Bosch en Lambert (de eerste bedrijfsleider van de commanditaire vennootschap, die uit de aardewerkfabriek van Clermont en Chainaye voortkwam, avi) om beurten probeerden elkaar te overtroeven met nieuwe technische vindingen' (ibid., p. 15).

2 Het moet gezegd dat veel bedeelden waarschijnlijk niet in staat waren bepaalde zware werkzaamheden in de fabriek te verrichten, zoals het vervoeren en bewerken van grondstoffen (zie de volgende paragraaf) en het werk bij de ovens. Inzetbaarheid is iets anders dan beschikbaarheid.

3 ... die, door het ambachtelijke karakter van de glas- en aardewerkproduktie (zie verderop), niét substitueerbaar waren.

4 Voor de buitenlanders kwam daar nog bij dat Maastricht in de jaren dertig een quasi-belegerde veste was, onder strak militair regime, met weinig vertier. Misschien was dat sommigen te veel van het goede: een industrieel èn een militair regime.

De aanwezigheid van een militair regime in Maastricht wordt in het Gedenkboek naar voren gebracht als een deel van de verklaring waarom er zoveel verloop was onder de spijkermakers van Regout's spijkerfabriek (die hier verder onbesproken blijft), waar in 1834 negen vaklieden uit Vaux in België werkzaam waren en twaalf Maastrichtenaren als leerling-spijkermaker (Regout, 1959: 26). 
waren niet de lonen die opvallend van de loonniveau's ${ }^{5}$ afweken, maar de frequentie van uitbetaling en het beloningssysteem. Hier heeft Regout de stijlnuimte aangegrepen om een duidelijk accent te leggen.

De uitbetaling aan ongeschoolde arbeiders en arbeiders in opleiding gebeurde niet dagelijks of wekelijks, zoals gebruikelijk (Brugmans, 1970: 147) maar om de twee weken - vandaar quinzaine, wat vermaastrichtst werd tot kìzjem. Dit was in Nederland zeldzaam (ibid., p. 147). Op de 'Quinzainelijst' stonden 'alle werklieden, welke oorspronkelijk dagloners waren tegenover de anderen, welke in stukloon werkten' (Regout, 1959: 121). Bij degenen die op stukloon werkten - een beloningssysteem dat in Nederland niet veel werd toegepast (Brugmans, 1970: 146) - werd in de jaren viffig, zoals vermeld in de gevalstudie, het systeem van de 'kleine kèzem' en 'groete kèzjem" toegepast: de eerste werd halverwege de maand verstrekt en was een voorschot op de tweede, die een afrekening was. In de beginjaren moet Regout aan de beambten, de geschoolde en ook de meeste ongeschoolde arbeiders (onder wie, waarschijnlijk, de stukloners) zells slechts één keer per maand hebben uitbetaald (Parlementaire enquête 1887, vr. 6665, Giele, 1981): een voor Nederland unieke situatie (Brugmans, 1970: 147). Later is de maandelijkse uitbetaling gelimiteerd tot de beambten en arbeiders met hogere lonen. Het motief voor deze uitzonderlijkheid was het administratief gemak dat ermee werd gediend, aldus Regout tegen de Staatscommissie van 1865 (Maenen, 1959: 349).

Bezat Regout met een maandelijkse dan wel tweewekelijkse uitbetaling een krachtig instrument om arbeiders voor zijn bedrijf te behouden? Wie wilde weggaan bleef minimaal éen tot maximaal bijna vier weken langer, maar het is de vraag of daarmee veel werd gewonnen. Aangaande de ongeschoolden maakte het dus nauwelijks iets uit, en het is moeilijk voorstelbaar dat bij veel andere arbeiders de reeds gemaakte opleidingskosten in zulke korte tijd konden worden terugverdiend. Maar als men een andere (in hoofdstuk 4 genoemde) consequentie van deze uitbetalingsfrequentie in overweging neemt, wordt het behoudmotief duidelijk. Door de arbeiders minder vaak geld te geven, werd de kans groter dat het loon vroegtijdig op was, wat weer leidde tot consumeren op krediet (Brugmans, 1970: 148), waarmee een belangrijke reden ontstond de werkrelatie

Maenen noemt de lonen in de Maastrichtse bedrijven (exclusief die van Regout) 'representatief voor het gehele land'. 'Vergelijkt men hiermee de lonen, die in Petrus Regouts fabrieken werden verdiend, dan komt men tot de slotsom, dat de vaklieden er in de aardewerkfabriek hoge lonen, die in de slijperij en in de blazerij zelfs zeer hoge lonen kregen. Daarentegen was er de beloning der ongeschoolde arbeiders laag, maar toch ook weer niet ongunstiger dan wat een ongeschoolde overal elders ontving" (1959: 337). De afwijking van het gemiddelde peil bij de vaklieden, vooral de slijpers en blazers, wordt veroorzakt doordat Maenen thier lokale appelen met buitenlandse peren vergelijkt. 
te continueren. ${ }^{6}$ Deze redenering - als deze bij Regout heeft gespeeld, wat waarschijnlijk is - berustte op de overtuiging dat veel arbeiders hun consumptiepatroon niet konden afstemmen op hun "budget".

Men kan deze maatregel zien als een hardvochtige (eerder dan zorgzame) en commenciële (eerder dan filantropische) vorm van een paternalistische behoudstijl. Dat hier niettemin van paternalistisch wordt gesproken en niet van liberaal is conform de definities. Hoe paradoxaal het ook klinkt: door in deze de arbeiders méér bestedingsvrijheid te geven, kan men - wetende dat zij deze luxe niet kunnen dragen - hen juist ertoe dwingen de arbeidsverhouding niet te verbreken. En dwang is onliberaal. Daarom kan men deze uitbetalingsfrequentie opvatten als een gemeinschaftlich behoudmiddel, al lijkt het een gesellschaftlich middel te zijn.

Regout heeft ook het overheersend gemeinschaftliche middel van het verplicht opbouwen van een tegoed aangewend. Met een Duits keramischgraveur-drukker, die bij Regout een drukkerij zou beginnen, kwam hij overeen dat deze de eerste twee jaren slechts vier-vijfde van het loon ontving en dat het resterende bedrag ( $\mathrm{O}^{\prime \prime} \mathrm{n} 12$ gulden per maand) als garamtie op rekening werd geschreven. Verbrak hij binnen deze twee jaar de werkrelatie, dan verspeelde hij zijn tegoed (omgekeerd verplichtte Regout zich tot uitbetaling van het dubbele rekeningsaldo als hij, Regout, de relatie zou verbreken). Na deze twee jaar zou de helft van het tegoed worden uitbetaald, waarna aan het eind van het derde jaar de andere helft zou worden verzilverd. Om deze regeling aantrekkelijker te maken zou de drukker vanaf het derde jaar aan het eind van elk jaar een gratificatie van circa 140 gulden ontvangen bovenop het volledig uitgekeerde loon (Maenen, 1959: 354). Of deze 'spaarvariant' door Regout vaker is toegepast, is niet bekend. Onwaarschijnlijk lijkt het allerminst.

Deze voorbeelden van gehanteerde gemeinschaftliche middelen kunnen met andere worden uitgebreid, waardoor de bewijslast in de richting van een paternalistische wervings- en behoudstijl wordt opgestapeld:

- de bepaling dat bij verbreking van de werkrelatie de arbeider het recht op terugvordering verspeelde op het in de ziekenkas gedeponeerde bedrag (Maenen, 1959: 388);

- het verbod voor arbeiders om hun gereedschappen mee naar huis te nemen terwijl ze hun eigendom waren. Dit gebeurde, aldus Maenen, waarschijnlijk om het verhandelen van gereedschap en het verkwisten van het geld daarvoor tegen te gaan. Maenen voert verder aan dat bedoeling van dit verbod is geweest '[..] de arbeider zorgvuldigheid ten aanzien van de gereedschappen in te scherpen' (1959: 370). Dat

${ }^{6}$ Natuurlijk kon men de schuld ook afbetalen met het loon dat bij andere werkgevers kon worden verdiend, maar deze alternatieven lagen niet altijd (gemakkelijk) binnen bereik. 
laatste is een beheersingsargument. Maar het behoudargument is eveneens duidelijk: wie vrij beschikt over zijn gereedschappen staat sterker op de arbeidsmarkt;

- werkgarandering en een minimumloon voor wie vijf achtereenvolgende dienstjaren bleef. Dit wervings- en behoudmiddel wendde Regout aan bij 'een onbekend aantal vaklieden' (Maenen, 1959: 354) toen genoemde Clermont en Chainaye in 1851 hun aardewerkfabriek begonnen en vaklieden bij Regout weglokten. Bij onderhandse acte legden deze vaklieden zich vast vijf jaar lang geen werk in een andere Limburgse aardewerkfabriek aan te nemen, waarbij Regout als tegenprestatie zich verplichtte gedurende dezelfde termijn onophoudelijk werk te verschaffen en hen een minimumloon te garanderen;

het instellen van een spaarkas. Maenen: Tegelijkertijd [met de hiervoor genoemde overeenkomst, avi] werd besloten tot oprichting van een Spaarkas, waarin een twintigste deel van het loon zou worden gestort tegen een rentevergoeding van $5 \%$. In geval de gecontracteerde werkman tussentijds bij zulk een andere aardewerkfabrikant in dienst zou treden, dan zou hij als schadevergoeding verbeuren viermal het loon, dat hij in de loop van de laatste drie maanden had ontvangen, alsmede zijn spaartegoed, hetwelk zou dienen ter dekking der registratierechten en andere onkosten. Van de boete zou in dat geval aantekening worden gemaakt in zijn "zakboekje voor ambachts-gezellen of maats" (livret d'ouvrier)' (1959: 355);

- het gebruik van dit livret d'ouvrier. Deze praktijk was in Nederland na de Franse tijd in onbruik geraakt. Een livret was in feite een legitimatiebewijs waarin door de fabrikant aantekeningen werden gemaakt en dat deze onder zich hield tot beëindiging van de werkrelatie (Maenen, 1959: 355-8; Brugmans, 1975: 150). Had iemand eenmaal een negatieve opmerking in zijn livret dan werd dat uiteraard als een restrictie gevoeld op diens arbeidsmobiliteit; hetzelfde gold al voor de dreiging dat het zou kunnen gebeuren.

Al deze voorbeelden lijken uitingen te zijn van een wervings- en behoudstijl waarin niet zozeer de instrumentele marktverhoudingen als wel de (waar mogelijk loyaliteitsafdwingende) hiërarchische verhoudingen de leidraad van Regout's handelen vormden. Daarom worden ze hier geëtiketteerd als paternalistisch.

\section{Huisvesting geschoolde arbeid}

Tot de belangrijkste 'secundaire arbeidsvoorwaarden' buiten de werkvloer is in het vorige hoofdstuk woningbouw en -verhuur aan arbeiders gerekend. In de gevalsbeschrijving is al vermeld dat Regout in het grote woonhuis aan de Boschstraat niet alleen zijn gezin, maar waarschijnlijk ook zijn eerste vaklieden onderbracht: de vier glasslijpers die in de trafiek werkten die Regout van 1826 tot 1834 in hetzelfde huis heeft geëxploiteerd. In dit 
bedrijfje, dat was gekoppeld aan zinn winkel en handelszaak, werden geimporteerd ruw glas en kristal geslepen. Deze trafiek is te beschouwen als een overgangsvorm van het uitbesteedsysteem naar het moderne fabrieksregime: net als thuiswevers namen deze slijpers slechts een deel van het produktieproces voor hun rekening, maar waren wèl al onder één dak geconcentreerd, waar ze onder handhaving van discipline werkten, zij het niet voortdurend in een gestaag tempo, relatief afhankelijk als ze waren wan de toevoer van grondstoffen.

Waarom gaf Regout een paar jaar later aan àl zijn nieuwe slijpers (maar liefst 37) huisvesting in het nieuwe, 'collossale' gebouw achter zijn woonhuis (zie de gevalsbeschrijving)? Volgens het Gedenkboek moesten de buitenlandse arbeiders 'op last van de militaire autoriteiten' (1959: 109) samen wonen. Heeft Regout daarom het grote gebouw opgetrokken? Nee, eerder werd, zoals de uitdrukking luidt, van de nood een deugd gemaakt: de arbeiders werden ondergebracht waar hij toch al uitbreiding van stoomslijpstoelen wilde realiseren.

Nog in 1841 wordt opgemerkt dat bij Regout veel arbeiders in de fabrijk" wonen. Dat dit op waarheid berust, bewijst een brandverzekeringspolis uit 1852 waarin dit staat vermeld. Men kan dus concluderen dat gedurende minstens een kwart eeuw arbeiders in Regoul's fabrieken hebben gewoond.

Is deze 'secundaire arbeidsvoorwaarde', al is deze aanvankelijk door de (militaire) overheid afgedwongen, een voorbeeld van een paternalistische stijl? Moeilijk te zeggen. Het is niet ondenkbaar dat er voor deze merendeels allochtone arbeiders geen geschikte onderkomens in de stad bestonden, zodat Regoul zich gedwongen zag hen in huis te nemen. Als woning* nood het enige motief is geweest, kan men bezwaarlijk spreken van paternalisme. Bestonden er wèl alternatieven, dan nog is het niet duidelijk: was hier sprake van een liberale stijl (huisvesting aanbieden als een additionele bron van inkomsten) of van een paternalistische stijl (arbeiders in de fabriek huisvesten om de mogelijkheden te vergroten gezags-en machtsverhoudingen, al dan niet via loyaliteitswerhoging, te bestendigen)? Het én hoeft het ander niet uit te sluiten. Dit huisvestingsaanbod van Regout behoort tot de categorie warin het gevneinschaftiche en gestllschaftiche elkaar overlappen.

\section{Het system oan de "platsen"}

De glas", kristal- en aardewerkfabriek wan Petrus Regout werd en wordt valak beschouwd als een van de eerste modeme fabrieken van Nederland. De ongekend grote personeelsomvang heeft hierin een rol gespeeld. Brug- 
mans spreekt terecht van een grootbedrijf 'dat alle andere in omvang ging overtreffen' (1975: 37). Hoe indrukwekkend de omvang van de Regoutfabrieken is geweest - reeds 1300 arbeiders in 1858 (Maenen, 1959: 333) tegen, bijvoorbeeld, 165 in de Amsterdamse stoomsuikerraffinaderij in 1857 (Brugmans, 1975: 40) ) $^{8}$ - daarmee behoren ze nog niet tot het moderne fabriekssysteem. Aan één kernvoorwaarde werd niet volledig voldaan: gestaag werkende machines die het werktempo dicteren. In de ardewerkproduktie, bijvoorbeeld, bleven belangrijke delen van het produktieproces vrijwel buiten de invloedssfeer van de stoommachine.

Het moderne industriële produktieproces voor aardewerken gebruiksartikelen vindt zijn oorsprong bij de Engelse fabrikant Josiah Wedgwood (1730-1795). ${ }^{9}$ Hij slaagde erin een aardewerksoort met een vrijwel witte scherfkleur te ontwikkelen, die bovendien harder en sterker was dan bestaande varianten. Zijn tweede innovatie was het gebruik van gips als vormmateriaal, waardoor de serieproduktie eenvoudiger - dat wil zeggen: minder ambachtelijk en meer gestandaardiseerd - kon plaatsvinden. Van mechanisering 'on the pot bank' was echter nog geen sprake (Thompson, 1980: 82). De wittere scherf maakte het bovendien mogelijk de decoraties direkt op het gebrande produkt aan te brengen en met een beschermende glazuurlaag af te dekken. Bij het decoreren maakte Wedgwood eveneens gebruik van een nieuwe techniek. Met gegraveerde koperplaten werden de afbeeldingen op het alardewerk gedrukt. Door dit procédé werd ook in deze fase van het produktieproces een stap in de richting van standaardisering gezet.

Ondanks deze innovaties bleef de aardewerkproduktie arbeidsintensief. De introductie van de stoommachine, aan het einde van de achttiende

${ }^{7}$ Dat is bij hem: ondernemingen met meer dan veertig arbeiders in dienst.

${ }^{8}$ Vergelijking met Twentse textielfabrieken (wat misschien méér voor de hand ligt) is vrijwel ondoenlijk omdat er in die tak van nijverheid zoveel huisindustrie woorkomt. Deze thuiswerkers werden doorgaans niet in de statistieken opgenomen.

${ }^{9}$ Hieronder is voornamelijk gebruikt gemaakt van het derde deelrapport van de Stichting Werkgroep Industriële Archeologie Maastricht (Mastricht, 1989), dat een industrieel-archeologische verkenning van de inmiddels gesloopte Société Ceramique bevat. Hoofdstuk 2 (pp. 33-9) is een beknopte beschrijwing van het produktieproces in de Maastrichtse aardewerkindustrie. Dit hoofdstuk leunt sterk op het overeenkomstige hoofdstuk uit het Gedenkboek 125 N.V. Sphinx-Céranique 100 (Regout, 1959). Hoofdstuk 4 is een registratie van de gebouwen, installaties en industriële relicten op het terrein van de Société Céramique. In dit hoofdstuk wordt nader ingegaan op de details van het produktieproces.

Neil Mckendrick heeft veel over Wedgwood geschreven: over zijn disciplinerimgspraktijken, zijn vriendenkring, zijn scheikundige experimenten, zijn boekhoudkundige vernieuwingen en zijn marketingtechnieken. 
eeuw, heeft een dempend effect gehad op de arbeidsintensiviteit, maar niet in die mate als in de textielindustrie of de suikerraffinaderijen, bierbrouwerijen en papierfabrieken. Hetzelfde geldt voor latere mechaniserende innovaties in de eerste helft van de negentiende eeuw.

Bij alledrie de hoofdfasen van de aardewerkproduktie - vormgeving, bestendiging en verfraaiing - bleef de aanwending van arbeid hoog. De bewerkingen voor, tussen en na deze fasen waren eveneens arbeidsintensief. Aan de loskade ${ }^{10}$ werden de grondstoffen - kolen, zand, diverse klei- en kaoliensoorten en toevoegingen als het smeltmiddel cornish stoneovergeladen in wagens die op smalspoor naar de fabriek liepen. Deze wagens werden doorgaans handmatig getrokken of geduwd. Binnen de fabrieksmuren werden de voorraden opgeslagen in lage loodsen (de nietplastische china-klei, die niet nat mocht worden) of in de open lucht (de plastische vette klei, het zand en de comish stone). De vette klei kon met een grijper uit de wagens worden overgeheveld; china-klei moest met de hand eruit worden gehaald en in kruiwagens de loodsen in gereden, wat zwaar werk was. Het cornish stone, in grote brokken aangevoerd, werd eerst met mokers en hamers in stukken geslagen, daarna in kollergangen aan een eerste vermaling onderworpen en ten slotte fijn vermalen in sleepkuipen, aangedreven door stoommachines, waarin ook het glazuur tot glazuurbrij werd vermalen. Het maalproces van de connish stone duurde, afhankelijk van de hardheid van de (Naamse) maalstenen, 36 tot 48 uur.

De vormgevingsfase begon bij het transport van de grondstoffen naar de kleimengmolens. De verschillende kleisoorten werden in korven geladen voor ze op de wagens naar de molens werden geplaatst. Met deze platte manden kon men bij benadering de benodigde hoeveelheden voor de menging toemeten. Bij de molens werden de korven weer op de schouder genomen en naar binnen gedragen. De kleimengmolens waren grote kuipen, eveneens door een stoommachine aangedreven, waar klei, zand, water en smeltmiddelen werden gemixt. Daarna werd de kleimassa doorgepompt naar de filterpersen, die in de regel op de eerste verdieping stonden en waar het meeste suspensiewater uit het mengsel werd verwijderd. Het filteren zelf gebeurde machinaal (het mengsel werd tussen schotten geperst, die op een stoommachine waren aangesloten), maar na de persing werd de kleimassa weer handmatig naar een ruimte gebracht (meestens: naar beneden gestort, de kleikelders in), waar het mengsel met draden tot handzame brokken werd getrokken, Voordat het mengsel in

10 In dit rapport wordt de situatie bij de Société Céramique beschreven, maar deze week niet structureel af van die bij de aardewerkfabriek van Regout. De werschillen zijn topografisch. Later werden de grondstoffen ook per trein aangevoerd. 
karretjes naar de produktieafdelingen werd vervoerd, werd de kleimassa vaak voor langere tijd in gesloten ruimtes bewaard, waardoor een homogenisering en een verbetering van de plastische eigenschappen van het mengsel werd bereikt. Vaak werd de massa dan tevens nog, met hetzelfde oogmerk, intensief gekneed.

Omdat de vormafdelingen zich vaak eveneens op de verdieping (van een ander fabrieksgebouw) bevonden, moest de kleimassa uit de karretjes omhoog worden gehesen, in een open lift, in Maastricht een tiersak genoemd, van het franse 'tirer' en 'sac'. Op verdieping gevormd aardew werk werd ook weer met de tiersak naar beneden vervoerd, naar de ovens.

De vormgeving werd beschouwd als het hart van de aardewerkfabriek (Stichting WIAM, 1989: 35). Vóór de komst van stoommachines werden alle artikelen geheel of gedeeltelijk uit de hand of met behulp van mallen gevormd. Dat de aanwending van stoomkracht bij het vormen bescheiden is gebleven, laat zich aflezen uit het feit dat slechts bij het vormen van 'eenvoudige' artikelen als borden de mensenhand en de met mensenhand volgegoten mallen werden vervangen. ${ }^{11}$ Meer complexe artikelen - waarvan de onderdelen in (dubbel- en enkelwandige) mallen waren gegoten moesten worden 'opgebouwd' door klein- en grootgarneerders (kannen en andere grote serviesstukken, of het aanzetten van oren) en/of te worden 'afgewerkt' door ovaaldraaiers, voor het maken van ovale terrines of soortgelijke stukken, en door afdraaiers, die elerdopjes, tuiten en dergelijke maakten. Sommige artikelen dienden zelfs helemaal met de hand te worden vervaardigd (luxe-serviezen op bestelling).

Deze ambachtelijke specialisten in de vormgeving werden in de regel bijeengebracht in een aparte afdeling, de draaierij, die zich meestal op verdieping bevond. Hetzelfde gold voor de gieterij. Op de benedenverdiepingen werd in het algemeen gebakken, geglazuurd en gedecoreerd, maar het stansen van borden gebeurde eveneens doorgaans op de begane grond.

Om het resterende water eruil te krijgen, werd het gevormde aardewerk vervolgens in droogkasten of op droogrekken gezet. Dit drogen duurde weken.

Voordlat het aardewerk de oven in ging, werd er zand overheen gestrooid om een gelijkmatige 'brand' te krijgen. De biscuitovens (het eerste brandproces werd incorrect de 'biscuitbrand' genoemd) werden aanvankelijk op kolen gestookt, later ook op gas. ${ }^{12}$ Als de artikelen weer uit de oven kwamen, werd eerst door meisjes het zandlaagje eraf geborsteld. Biscuitartikelen waren echter te poreus voor dagelijks gebruik; een tweede

11 Het machinaal persen van artikelen heet 'stansen'.

12 Daarom, onder andere, heeft Regout een gasfabriek opgericht. 
brand" - de glazuurbrand - was daarom noodzakelijk. Niet alleen omdat het decoreren aan deze tweede brand vooraf kan gaan, maar ook omdat het glazuren zelf een verfraaiend effect op het aardewerk had, wordt de glazuurbrand tot de derde fase gerekend: de verfraaing.

Decoreren kon op twee momenten in het produktieproces plaatsvinden: tussen de biscuitbrand en glazuurbrand (de 'onderglazuur'-decoratie) en ná de glazuurbrand (de 'opglazuur'-decoratie). ${ }^{13}$ Tussen biscuitbrand en glazuurbrand zijn er dus twee mogelijkheden: i) het biscuitaardewerk wordt meteen geglazuurd of ii) het wordt eerst in de decoratie-afdeling gedecoreerd.

Rond 1850 bestonden verschillende decoratietechnieken: de afbeeldingen of motieven werden op het aardewerk geschilderd, gedrukt, gespoten of geplakt. Bij het drukken bracht men, met gegraveerde koperplaten en een drukpers, verfpatronen over op het aardewerk; het spuiten van verfsuspensies geschiedde doorgaans met behulp van sjablonen; het plakken met hulp van decalcomanieprenten ofwel afdrukpapier. Vergeleken met het schilderen waren deze drie decoratietechnieken veel minder bewerkelijk en nauwelijks ambachtelijk te noemen. Bij massaproduktie nam deze "nieuwe' technieken een steeds belangrijker plaats in.

De gebruikte verf (althans de anorganische pigmenten) werden vaak zelf vervaardigd; zo kreeg men bedrijfsspecifieke kleuren als Delfts Blauw. Deze verfafdelingen kenmerkten zich daarom eveneens door een grote mate van ambachtelijkheid. Voor het aardewerk de glazuuroven in ging, werden de artikelen met tangen en vingerbeschermers ondergedompeld in de glazuurpapkuipen, gevolgd door een korte droogtijd.

Geglazuurd aardewerk dat een opglazuur-decoratiebehandeling moest ondergaan, ging terug naar de decoratieafdeling. Daar werden de verfraaiingen - opglazuur decoratie werd meestal toegepast bij felle kleuren of gouden biezen - op een temperatuur van $700^{\circ} \mathrm{C}$ als het ware in de glazuurlaag gesmolten om hechting (en daardoor slijtvastheid) van de decoratie te bewerkstelligen. Opglazuur betekende dus een derde branding: de decorbrand.

$\mathrm{Na}$ enkele afwerkingshandelingen (zoals het verwijderen van puntjes op de plaatsen waar het aardewerk op steunen had gestaan) ging het aardewerk naar de pakkerij, waar de artikelen in stro of kuipen werden verpakt. Via de expeditie werden de gerede produkten grotendeels opnieuw per schip of per spoor afgevoerd.

In de negentiende-eeuwse aardewerkindustrie werd aan twee kernvoorwaarden van het moderne fabrieksregime voldaan: concentratie van pro-

${ }^{13}$ Er werd uiteraard ook veel ongedecoreerd aardewerk vervaardigd. 
duktie en handhaving van discipline. ${ }^{14}$ Deze concentratie in grote fabrieken was ook hier te begrijpen in het licht van technische èn sociale motieven: enerzijds de aanwending van stoommachines en daardoor aangedreven slijpstoelen, draaibanken, kuipen, etc., anderzijds de wens beter gedisciplineerde arbeiders te kweken die produkten van hogere kwaliteit vervaardigden. Maar aan de derde voorwaarde - gestaag werkende machines die het tempo dicteren - is slechts beperkt voldaan. Daarom kunnen aardewerkfabrieken niet zonder meer met het etiket 'modern fabriekssysteem' worden gesierd. Door de hoge mate van complexiteit en ambachtelijkheid - of: de onmogelijkheid om werkzaamheden te formaliseren, laat staan te standaardiseren - werd slechts in bepaalde fasen van het produktieproces het werktempo gedicteerd door de stoommachine - zoals bij de kleimengmolens, de sleepkuipen, de filterpers en het stansen op de bordenafdeling. Deze molens, kuipen, persen en stansmachines waren echter niet voortdurend in gebruik: 'opgehouden ${ }^{15}$. als ze werden door fasen in het produktieproces die een niet-continu karakter droegen. Ondanks deze dubbele beperking kan men de aardwerkproduktie ook weer niet gelijkstellen aan het volstrekt discontinue werktempo in, bijwoorbeeld, de acht-

14 Concentratie in tabrieken betrof niet alleen de produktie van aardewerk: waar mogelijk werden grond-en hulpstoffen zelf geproduceerd en in ieder geval zelf bewerkt. Ook het fabriekscomplex van Regout omvatte een aantal kleinere fabrieken waar hulpstoffen werden geproduceerd: zoals een gasfabriek en een verffabriek.

Aardewerkfabrieken kenden een gecompliceerde morfologie: een groot aantal produktie-afdelingen, opslagruimten, etc., wat zich herhaalde in de grond-en hulpstoffenfabrieken. De meeste van deze gebouwen, loodsen en shelters waren op meervoudige wijze interdependent. In dit geheel stonden de molen- en ovengebouwen centraal; alle andere waren erop georiënteend. Deze andere gebouwen waren in principe multi-functioneel: meerdere aktiviteiten konden er plaats vinden. In de molen- en ovengebouwen was dat niet het geval en daarmee waren deze "onwrikbaar".

15 Deze vertraging of oponthoud kon op twee manieren plaatsvinden: i) doordat de niet-continue werkzaamheden het tempo van de door stoommachines gedicteerde werkzaamheden niet konden bijbenen, waardoor in de continue sfeer wachttijden ontstonden (de input uit de vorige fase stokte, ondat men daar nog niet 'zover' was, em/of de output naar de volgende fase stokte, omdat men daar nog "volop bezig was") en ii) doordat er op verschillende platisen in het produkfieproces ontkoppelingspunten bestonden: daar waar grondstoffen en halffabrikaten in magazijnen werden opgeslagen niet zozeer om als tussenvoorraad te dienen, als wel omdat het produktietechnisch vereist was, zoals het droogproces na vorming van het aardewerk dat weken in beslag nam. Toch heeft de aanwending van stoommachines bij verschillende werkzaamheden ook een temporegulerende (doorgaans: tempoverhogende) werking op werkzaamheden in voorafgaande en volgende fasen van het produktieproces gehad. 
tiende-eeuwse machinefabricage of ijzerindustrie. Men kan bij de gemechaniseerde onderdelen van de aardewerkproduktie het beste spreken van 'interval-continu': van tijd tot tijd in een gestaag tempo.

De niet-continue werkzaamheden waren niet alle ambachtelijk. Denk aan het vervoeren van grondstoffen, halffabrikaten en eindprodukten, het stukslatan van de corrish stone, het in stukken snijen van het kleimengsel, het gieten, garneren en draaien van het aardewerk, het zanden en ontzanden, verschillende manieren van decoreren, het aambrengen van de glazuurlaag, het afwerken, het vervaardigen van bijbemodigdheden, enzovoort.

Een aantal van dergelijke niet-continue werkzaamheden zal men ook aantreffen in fabrieken die men wèl zonder voorbehoud moderne fabrieksregimes mag noemen. Het betreft dan echter randaktiviteiten die geen invloed uitoefenen op het tempo van het eigenlijke produktieproces. Deze werkzaamheden bevinden' zich meestal aan het begin en het einde van het transformatieproces en in 'zijstappen' als magazijnen. Hiertoe behoren zowel ambachtelijke als niet-ambachtelijke werkzaamheden.

Doordat het produktieproces van aardewerken artikelen zowel elementen vertoont van het moderne fabriekssysteem als van andere vormen (van de ambachtelijke werkplaats, zoals de vormerij en de decoratie-afdeling, en van de niet-continue traditionele fabrieken, zoals het werk bij de ovens ${ }^{16}$ ) kan men binnen één fabriek vergelijkingen trekken en daarmee tot een helderder inzicht in de problematiek van werving, behoud en beheersing komen. Bovendien kunnen fricties tussen verschillende systemen van produktie en organisatie duidelijk in dergelijke hybride fabrieken worden herkend.

Wat hier is geschreven over de aardewerkproduktie geldt m.m. ook voor de fabricage van glas en kristal. Vandaar dit schema:

${ }^{16}$ Ook toen de biscuit-, glazuur- en decorbrandovens al volcontinu in werking waren (waardoor er dag en nacht bij Regout werd doorgewerkt) "moesten bijvoorbeeld de ovens waarin de glazuurpap werd vervaardigd elke 6 à 8 weken worden gedoofd, omdat anders door de looddampen de wanden dreigden te bezwijken. 
stuk- \& seriestukproduktie heterogene massaproduktie

[

samen-

gesteld enkel-

woudig homogene

massaptoduktie

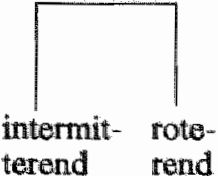

\section{glas-, kristal- \& aardewerkfabrieken van Regout}

moderne fabrieksregime

Dit samengaan van 'oude' en 'nieuwe", discontinue en continue elementen heeft belangrijke consequenties gehad voor de stijl van werven, behouden en vooral beheersen.

Het meeste ambachtelijke werk werd verricht in de 'plaatsen': de kleine werkgroepen $^{17}$, kort beschreven in hoofdstuk 2, met aan het hoofd een

17 In termen van Henry Mintzberg (1979)(zie h.4) zou men kunnen spreken van een simpele structuur binnen een meer omvangrijke simpele structuur (de fabriek), die zich echter ontwikkelt in de richting van een machine-bureaucratie.

Mintzberg's typologie van organisatiestructuren kan ook als een leidraad dienen bij het schrijven van bedrijfsgeschiedenissen. Zo zouden Regout's glas-, kristal- en aardewerkfabrieken zich kunnen laten beschrijven als een overgang van een adhocratie ("Adhocracy") via een eenvoudige structuur en machine-bureaucratie naar een divisionele structuur ('Divisionalised Form') na Petrus Regout's overlijden.

Het is denkbaar dat in de allereerste jaren (tot 1840) de zakenman Regout in onderlinge afstemming (het kenmerkende coördinatiemechanisme in een adhocratie) met zijn eerste groep buitenlandse vakarbeiders tot het opzetten en reproduceren van het produktieproces $\mathrm{kwam}$. De kennis van de produktie was immers groter bij deze werkkrachten dan bij de entrepreneur zelf. $\mathrm{Na}$ een aantal jaren zal deze achterstand zijn weggewerkt, waarna de entrepreneur méér en beter directe supervisie (het kenmerkende coördinatiemechanisme in een eenvoudige structuur) kan uitoefenen, vooral ook op de tweede generatie vaklieden en de ongeschoolde arbeidskrachten die worden aangetrokken bij de overstap naar massa-produktie (rond 1840) en die niet in de werkgroepsverband zijn ingezet. Deze overstap echter brengt een toename van mechanisering en standaardisering van werkprocedures met zich, die een zwenking in de richting van een machinebureaucratie betekent. Samen met de standaardisatie van werkprocessen (het 
vakarbeider, de maittre-ouvrier, die leiding had over twee 'gewone' arbeiders en een viertal leerjongens, die zowel door hem werden gesuperviseerd als opgeleid (Maenen: 273). ${ }^{18}$ Al waren de werkzaamheden van de jongere gamins licht - aanreiken, wegzetten en schoonmaken van woorwerpen - dit lichte werk werd aanzienlijk verzwaard doordat het elf uur lang moest worden gedaan, ook 's nachts (Maenen, 1959: 273; die wordt aangehaald in: Goudswaard, 1981: 192) en tegen een laag loon. ${ }^{19}$

kenmerkende coördinatiemechanisme in een machine-bureaucratie) wordt het accent verplaatst van het topmanagement (Regout) naar de specialisten die het produktieproces plannen en bewaken, de zogenaamde technostructuur ("technostructure), die daarmee de sleutelpartil in de organisatie wordt. Doordat echter zowel de glas- als de aardewerkfabricage in belangrijke mate een ambachtelijk en arbeidsintensief karakter blijft behouden (zie verderop), blijven er eilanden van eenvourdige structuren in de organisatie bestaan, die de sturende en regulerende macht van de technostructuur in belangrijke mate inperken en waardoor formalisering van gedrag en verticale en horizontale taakspecialisatie gelimiteerd blijven. Wanneer na het overlijden van Petrus Regout in 1878 de fabrieken worden verdeeld onder zijn erfgenamen, wordt ook naar rechtsvorm duidelijk wat het industriele imperium van Regout altijd al tevens is geweest: een divisionele structuur.

${ }^{18}$ Dat de maitrewouvrier bij Regout verantwoordelijk was voor het opleiden van de leerjongens, en ook nog voor het aannemen en de uitbetaling van het loon, is niet uitzonderlijk. De historicus Sydney Pollard (1965: 38-47) beschrijft dit uitbesteden van aannemen in de textielindustrie, ijzerindustrie, mijnbouw, enzovoort. N. Goudswaard hierover in zijn studie over het nijverheidsonderwijs in Nederland: "Als een gamin zich meldde werd hij, naar getaxeerde geschiktheid, in een bepaalde ploeg aan het werk gezet en opgeleid naar richtlijnen, door de betrokken meester vastgesteld. Uit sommige contracten blijkt, dat speciale lessen werden gegeven in vaktheorie: in $1843 \mathrm{kwam}$ de fabrikant [Regout, avi] met een schilder overeen, dat deze bij hem zou komen werken tegen $/ 2,75$ per dag, warvoor hij moest ontwerpen, tekenen en tekenonderricht geven aan leerlingen. In 1866 bestond er een "schrijnwerkersatelier" of leerschool, terwijl in de toelichting van een omstreeks 1868 vervaardigde afbeelding der fabrieken over een der gebouwen werd vermeld, dat zich daarin bevond une infirmerie pour les Ouvriers et une école pour les enfants d'ouvriers de bas âge'. In verscheidene contracten kwamen bepalingen voor die wijzen op de plicht van de ambachtsmeesters om aan hum personeel een gedegen opleiding te geven en tevens om aan de fabrikant en/of zijn zoons "de volledige kunst" van het vak over te dragen. Dat hield hier in, dat de meester zijn composities uitsluitend in tegenwoordigheid van de leerlingen moest samenstellen en hen daarbij alles omtrent zijn eigen kennis moest verklaren' (1981: 192).

19 Een eerste gamin verdiende 40 à 50 cent per dag; een vierde gamin 15 tot 20. Een maître-ouvrier echter 350 tot 475 cent per dag (en een souffleur 175-250 en een carreur 80 tot 100 cent) (Maenen, 1959: 335). 
Goudswaard spreekt over deze plaatsen van 'een ambachtelijke structuru' (1981: 78). Soortgelijke ambachtelijke afdelingen neemt hij waar bij de eerste Nederlandse machinefabriek van G.M. Roentgen te Amsterdam, waar men een ijzergieterij had, een kopergieterij, een draaierij, enzovoort.

Ik heb proberen aan te tonen dat een dergelijke gilde-achtige structuur in de glas- en aardewerkindustrie min of meer werd afgedwongen door de aard van de werkzaamheden in sommige onderdelen van het produktieproces. Het hoog ambachtelijk karakter van het glasblazen en het aanbrengen van versieringen (om nu voorbeelden uit de andere industrie te nemen) vereiste een lange leerperiode ${ }^{20}$ met een nauwgezette begeleiding van een vakman. Deze vakman-voorman leerde zijn leerlingen, naast de benodigde kennis en vaardigheden, ook zich het ritme, de zelfbeheersing en de samenwerking - de modern-industriële basisvereisten - eigen te maken. Dat was, denk ik, eerder de overdracht van een reeds eigengemaakte fabriekspraxis dan de uitvoering van een opdracht van hogerhand (van Regout). Dat hoort bij dit werk, zullen de maitre-onviers min of meer onbewust hebben gedacht, en leerden dat dan ook hun leerlingen aan. Het was juist op deze geinternaliseerde opvattingen aangaande de eisen van de industriële vervaardiging van consumptie-artikelen dat de principaal van deze agenten ${ }^{21}$, Petrus Regout, rekende. Aan de agenten werd de gedurige controle, de ononderbroken supervisie toevertrouwd, zadat de principaal kon volstaan (of meende te kunnen volstaan) met incidentele controle in de vorm van inspecties en steekproeven. Denk aan de legendarische nachtelijke bezoeken van Regout in nachtgewaad aan zijn fabrieken, genoemd in de gevalsbeschrijving. Sommigen zouden dit nu manngementby-walking-around noemen. Dit verhaal of deze legende kenmerkt zich door een interessante ambiguïteit. Het element van onverwacht controleren attendeert op het 'slechte' in Petrus Regout; het nachtgewaad, de slaapmuts en de kaars zwakken dit kwade af: het tafereel heeft iets goedmoedigs, het doet denken aan een biedermeier-schilderij. Een beroemde eigenaardigheid van Josiah Wedgwood was zijn smijtlust: aardewerk dat niet aan zijn maatstaven voldeed, gooide hij in gruzelementen, waarna hij meerdere malen op de werkbank zou thebben gekalkt: "this won't do for Josiah Wedgwood' (McKendrick, 1966: 75). Ook hier is het niet alleen de mengeling van feit en fictie, maar ook die wan hardvochtigheid en goedhartigheid (ruwe bolster.. etc) die het verhaal ambigu maakt.

Hofstede (1980, 1991) ziet 'helden' als belangrijke elementen van een (organisatie)cultuur: de stichter van een bedrijf is vaak een lichtend

20 Bedenk dat glas, kristall en aardewerk breekbare produkten zijn, waarmee extra voorzichtig moet worden omgegaan.

$21 \mathrm{Om}$ de terminologie uit de agency-theorie weer te gebruiken. 
voorbeeld, naar wie leden van latere tijden hun opvattingen en gedrag kunnen modelleren. Tegenover helden stelt Hofstede 'anti-helden' die een zelfde functie kunnen vervullen, maar dan als voorbeeld-hoe-het-nietmoet. Onder industriele pioniers kan men beide vinden - met die toevoeging dat veel anti-helden later alsnog helden zijn geworden.

Een voordeel van dit ambachtelijke systeem was dat vaklieden binnen de fabrieksmuren een deel van de voorrechten, vrijheden en beroepstrots konden handhaven. Door hen zekere verantwoordelijkheden, voorrechten en omspanningsvermogen (span of control) te gunnen, hoefden ze zich minder gedegradeerd te voelen, wat hun motivatie kon bevorderen. Niettemin zal het contrast tussen fabriek en werkplaats vervreemding hebben teweeggebracht: in de werkplaats hadden de vaklieden meer ruimte en meer tijd.

Aangenomen dat de ambachtelijke aard van het werk binnen deze groepen noodzaakte dat er de personeelsbeheersingsmiddelen opleiding en culturele beheersing (zie h. 4) werden toegepast, dan moet, wil men te weten komen of er op dit punt stijlruimte bestond, de vraag worden gesteld of deze werkgroepen een permanent karakter hadden in plaats van een tijdelijk, waar alleen de benodigde kennis en vaardigheden werden aangeleerd. Het feit dat naast de gamins ook twee volwassen, tamelijk geschoolde arbeiders blijvend deel uitmaakten van deze 'plaatsen' en dat deze twee - de souffleur en de carreur - samen met de gamins werden gesuperviseerd door de meester-knecht lijkt mij een duidelijk voorbeeld dat met deze werkgroepen niet alleen training*on*the-job en culturele beheersing ten behoeve van ritme, zelfbeheersing en samenwerking werd beoogd, maar ook, daarbovenop, een permanente paternalistische praktijk gestalte kreeg, die men als een uiting kan zien van een blijvende voorkeur voor een nadruk op personeelsbeheersing waar deze mogelijk was.

Daarom beschouw ik deze werkgroepen ${ }^{22}$, in deze samenstelling, als een uiting van een paternalistische beheersstijl. Het was immers ook mogelijk geweest afzonderlijke werkgroepen te formeren van geschoolde arbeiders die hoofdzakelijk of uitsluitend werden beoordeeld op hun activiteiten (of, indien mogelijk, hun resultaten).

De meesterknechten zelf werden beoordeeld op hun resultaten: "De ploeg als zodanig werkte op stukloon; aangezien nu alle ondergeschikten van een meester een vast loon ontvingen, was alleen het loon van de meester

22 Die bovendien de interne arbeidsmarkt klein en traag hielden: overstappen van de ene werkgroep naar de andere kwam even weinig voor als vlug opklimmen van vierdle gamin tot meester. 
afhankelijk van de behaalde resultaten' (Maenen, 1959: 288). ${ }^{23} \mathrm{De}$ paternalistisch gekleurde - beheersing van activiteiten en attituden van de arbeiders werd uitbesteed aan meesterknechten die op hun beurt werden beheerst via het liberalistische middel van het stukloon.

Met dit systeem van werkgroepen waren de problemen van discipline en coördinatie voor de fabrikant minder nijpend. Het stukloon was voor de meesters een krachtige prikkel een hoge (en kwalitatieve, want afgekeurde en teruggestuurde artikelen werden onder het tarief gehonoreerd en soms zelfs beschouwd als niet-aangekomen) groepsproduktie te leveren dan wel af te dwingen; de werkstructurering en de directe supervisie die aan hen werd overgelaten een vruchtbare vorm van coördineren. De problemen werden verlegd naar een lager niveau en daarmee min of meer uit de wereld geholpen - zij het dat een hoog loon voor de meesters de prijs was die fabrikanten als Regout ervoor moesten betalen.

In de glas-, kristal- en aardewerkindustrie was resultatenbeheersing beter mogelijk dan in industrieën die geheel of grotendeels 'continu' waren. In 'continue' fabrieken zijn de te beheersen werkzaamheden in grote mate afhankelijk van door andere arbeidskrachten te verrichten werkzaamheden, waardoor het 'ophakken' in fasen met kwantitatief meetbare (half-) resultaten moeilijk is. In 'semi-continue' fabrieken als die van Regout, waar belangrijke fasen van de produktie relatief autonoom van het door machine of voorman gedicteerde tempo moesten geschieden, kon beheersing via resultaten betrekkelijk eenvoudig worden toegepast, in het bijzonder met het instrument stukloon.

Binnen de 'plaatsen' werd door de meester-knechten vanzelfsprekend ook beheersing van handelingen toegepast, voornamelijk in de vorm van gedragsbeperkingen en het laten verantwoorden van aktiviteiten. Beide werden vergemakkelijkt door de kleine fysieke en ook sociale afstand tussen meester, arbeiders en gamins. ${ }^{24}$

Een belangrijk deel van de gedragsbeperkingen stond geformuleerd in het fabrieksreglement, dat zowel voor de arbeiders in de 'plaatsen' als die erbuiten gold. Daarmee werden de meesters van een deel van hun gedragsbeperkende taken ontheven; hetgeen naar twee kanten kan worden uitgelegd: als ontzegging van een deel van hun macht of als vergemakkelijking van hun werk. Van Regout"s fabrieken is slecht één reglement

${ }^{23}$ In die zin zou men deze werkgroepen als proto-divisies kunnen schouwen.

24 Op langere termijn zullen de beheersing van handelingen van gamins ook wenselijke gedrags- en attitude-effecten hebben gesorteerd. Het is atannemelijk dat door gestadige aktiviteitenbeheersing de individuele zelfcontrole van gamins werd geëntameerd en verhoogd. 
bewaard gebleven: dat van de kristal-en glassliperij, uit 1851 (Zie voor de volledige tekst: Maenen: 1959 365-8).

De twintig artikelen wan dit reglement bevatten nauwelijks gedragsbeperkingen op de werkvloer, tenzij men de reeds genoemde verboden aangaande het gebruik van werktuigen en gereedschappen buiten de fabriek (artikel $15 \& 16$ ) of de verplichting voor leerling-slijpers om elke zaterdag hun draaischijf, raam en gaspit te reinigen als zodanig wil aanmerken. De toevoegingen ('En outre..') bij artikel 20 bevatten wè]. duidelijke gedragsbeperkingen:

Tout tailleur qui dans l'établissement en viendraït aux mains ou se permetrait des envies de fait aura une amende de frs. 10, m.

Celui qui jouerait en jetant de sable, de l'eau etc. ou qui par tout autre moyen empêchera le travail sera puni d'une amende de frs. 5,-Celui qui fumera dans la taillerie sera passible d'une amende de firs. $1,-$

Celui qui allumera son bec de gaz aura une amende de frs. 0,25.

Celui qui jurera ou proferera des blasphimes sera puni chaque fois d'une amende de frs. 0,50 .

Personne n'ose s'arrêter près du poêle pendant les heures de travail sous peine d'une amende de frs. 0,25.

Tout tailleur surpris à rôder ou à jaser sur d'autres places que la sienne sera puni d'une amende proportionelle à ses gages et au temps manqué.

Au surplus l'employé chargé de la surveillance de la taillerie aura la latitude de punir, selon l'importance, l'ouvrier qui lui manquera de respect, ou qui commetra une inconvenance non prévue dans le présent règlement. 25

Het laten verantwoorden van aktiviteiten - definiëren en controleren van de gewenste of acceptabele acties, waarna belonen of bestraffen van afwijkingen van de gestelde normen - kan niet anders dan dagelijkse praktijk binnen de werkgroepen zijn geweest. Het definiëren van de gewenste

25 Maenen houdt het voor mogelijk dat in een algemeen fabrieksreglement geboden en verboden hebben gestaan, zoals met betrekking tot het niet-specifieke vergrijp dronkenschap, die in de afzonderijke reglementen net werden herhaald.

Ook moet men bedenken dat bepalingen omtrent werkijden, die van fabriek tot fabriek konden verschillen, eveneens als een vorn van aktiviteitenbeheersing kuntuen wonden beschouwd.

Overigens waren de boetes, net als in Wedgwood's fabrieken, allesbehalve licht te noemen. Men kan gerust Mckendrick nazeggen: "It is unlikely that they were often ignored" (1966: 76). 
acties, ofwel verstrekken van richtlijnen en opdrachten aan de souffeur, carreur en de gamins, zal in bijna alle gevallen mondeling zijn gebeurd. Schriftelijke definities van gewenste acties - bijvoorbeeld werkkaarten of handleidingen - zijn in de beginjaren van de Industriële Revolutie vrijwel niet opgesteld. De altoos en alom aanwezige meester keek en beoordeelde eenvoudig of de werkzaamheden naar wens werden verricht: of alle produkten aar de kwaliteitseisen voldeden, of grondstoffen en kapitaalgoederen efficiënt werden gebruikt, of er gedisciplineerd en gecoördineerd werd gewerkt, enzovoort - en stuurde bij waar nodig.

De samenstelling van de werkgroepen - met daarin de permanente aanwezigheid van volwassen arbeiders, die, zo mag men aannemen, zowel een bijdrage moesten leveren aan de scholing en beheersing van de leerlingen als zelf bij voortduring aan het bevoogdende leer-aspect bleven blootstaan - is als een voorbeeld van een patermalistische beheersstijl naar voren gehaald. Dit voorbeeld kan worden uitgebreid met legio verspreid bewijsmateriaal.

Zo heeft Regout ook gratificaties voor gedrag en vlijt verstrekt. Maenen heeft daarvan één voorbeeld gevonden - een machinist die honderd gulden had ontvangen 'voor drie achtereenvolgende jaren gehouden onbesproken gedrag en vlijtigheid", aldus een onderhandse acte uit 1854 (Maenen, 1959: 359). Het lijkt niet te gewaagd te veronderstellen dat dit geen incident was, maar het is onmogelijk te zeggen in hoeverre hier sprake was van een beheersingspraktijk. Bij fabrikanten als Wedgwood en Arkwright - zo'n driekwart eeuw eerder begonnen - was belonen en aanmoedigen al gebruik; zo beloonde Richard Arkwright zijn meest verdienstelijke arbeiders met 'distinguishing dresses', wat grote naijver opwekte (McKendrick, 1966: 73).

Wat te denken van de verplichting voor leden van de ziekenkassen om de jaarlijkse Hoogmis bij te wonen voor de zielerust van de overleden leden op straffe van uitsluiting van ziekengeld tijdens de eerstvolgende drie maanden (Maenen: 385) en het laten instellen van een zondagsdienst in de nabije St.-Matthijskerk waar, speciaal ten behoeve van de vele Franstalige arbeiders, in het Frans moest worden gepreekt (ibid., p. 385)?

Een laatste 'piece of evidence' ten ondersteuning van de veronderstelling dat Regout een paternalistische stijl hanteerde: de bedrijfsharmonie die hij in 1842 oprichtte om het bezoek van koning Willem II luister bij te zetten. Dit aanvankelijk bescheiden initiatief ging al vlug andere doelen dienen. Ten eerste het vermeerderen van Regout's status: de harmonie trad in een concurrentie met de gevestigde plaatselijke harmonie, de Société d'Harmonic Royale. Maar de eerste bedrijfsharmonie van Nederland diende ook, mag men aannemen, het behoud en de beheersing van zijn arbeiders: een 45 à 60 uit het personeel gerecruteerde muzikanten werden ermee aan 
het bedrijf gebonden. Bovendien moet er een muziekschool aan de harmonie zijn verbonden, die naast een instrumentale ook een zangklas kende, die hootdzakelijk tot aankweking van werkende leden voor dat gezelschap' diende, aldus het Verslag van B\&W Maastricht aan de gemeenteraad uit 1851 (aangehaald in Maenen, 1959: 369). De grootste bloei kende de harmonie nadat in 1859 Nicolaus van Polfliet met de leiding was belast. De 'Poltenennekes-Herremenie', zoals de harmonie werd genoemd, 'werd bekostigd uit de bijdrage welke de werknemers die meer dan 25 francs per maand verdienden, verplicht waren maandelijks daartoe af te staan' (Quaedvlieg, 1979: 36). Nadat in de jaren zestig de protesten daartegen van de honoraire leden, dat wil zeggen: de 'beter' betaalde arbeiders, luider werden, schafte Regout de harmonie in 1870 af.

Dit alles ten spijt mag officieel niet worden geconcludeerd dat Petrus Regout een paternalistische stijl had ontwikkeld. Falsificiërende voorbeelden zullen niet moeilijk zijn te vinden. Toch wijzen genoeg signalen in dezelfde richting om vooralsnog aan te houden dat Petrus Regout zich kenmerkte door een paternalistische stijl. Met het beschikbare betrouwbare historische materiaal zie ik geen andere conclusie.

Toch zijn de ambiguïteiten in de gegeven voorbeelden groot. Ambiguilteiten met betrekking tot de omvang van de stijlruimte in kwestie. Ambiguiteit in de zin van tweeslachtigheid tussen paternalistische en liberalistische stijl. Daarom heb ik in de volgende paragrafen enkele van de meest pertinente en boeiende ambiguiteiten uitgediept.

\subsection{Arbeiderswoningbouw door Petrus Regout: de 'cité ouvrière' in de Sint-Anthoniusstraat ${ }^{26}$}

"De cité ouvrière die ik voornemens ben op te rigten, zal nagenoeg vijftig woningen bevatten, waar even zoo veel huisgezinnen van de arbeidende klasse tegen geringe huur, goede en gezonde huisvesting zullen vinden, zoodat het nuttige van dat uitgestrekte gebouw, voorzeker zal erkend worden.'

Petrus Regout in een (gedrukt uitgegeven) adres aan de gemeenteraad van Maastricint, 1863.

26 Een eerste en meer uitgebreide versie van deze en de volgende paragraaf verscheen als working paper 87-025 van de Faculteit der Economische Wetenschappen, Rijksuniversiteit Limburg. 
Une grande cité Ouvrière genre moderne servant à 72 ménages rend des immenses services à l'égard de la salubrité des nombreuses familles."

P. Regout, onderschrift bij lithografie 'Vue générale' in: Album dédié a mes Enfants et mes Amis, Pierre Regout à Maestricht, Parijs \& Maastricht, 1866.

'In 1863 stichtte hij den later zoo berucht geworden 'Groete Bouw' in de Sint-Antoniusstraat, het befaamde menschenpakhuis. Dit was ingericht volgens de toenmalige efficiëncy des heeren Regout, n.l. om met een zoo klein mogelijk kapitaal een zoo hoog mogelijk 'rendement' te bereiken. In dit als pakhuis uitziend gebouw werden circa 400 menschen geborgen, op zeven verdiepingen boven elkaar. Een lift was er niet in aangebracht. Op iedere verdieping hing een groot Christusbeeld. De hygiëne liet zeer veel te wenschen over - de latrines waren zonder deuren en zonder closets, terwijl de luchttoevoer onvoldoende was - met gevolg, dat groote sterfte in dit 'huis' te voorzien was en voorkwam.'

M. Ubachs, Een eeuw modern kapitalisme. De Regouts. Leed en strijd van Maastricht's proletariaat, Tongeren, 1934.

Als belangrijkste attractie-instrument buiten de werkvloer is in het vorige hoofdstuk ( $(2)$ genoemd: het bouwen door fabrikanten van arbeiderswoningen dan wel opkopen en in gereedheid brengen van bestaande woningen. Arbeiders konden worden aangelokt door een lagere huurprijs te vragen en/of méér comfort te bieden dan wat anderen (met name woningbouwspeculanten) vroegen en boden, of wat migrerende arbeiders gewend waren. Huisvesting voor arbeiders werd ook ingezet als behoudmiddel: de huurprijs en het comfort konden bemoedigen de werkrelatie te continueren; en door te dreigen en/of contractueel vast te leggen dat bij beëindiging van de werkrelatie ook de gehuurde woning moest worden. ontruimd, kreeg woningbouw en -verhuur ook de functie van ontmoedigend en restrictief middel. In daaropvolgende paragraaf werd gesteld dat woningbouw fabrikanten ook te stade kwam bij het beheersen van arbeiders. Inspecties werden tot een vorm van (Merchant's) action control gerekend, die echter tot doel had een attitudeverbetering te bewerkstelligen, waarmee deze beheersingsvorm toch onder personeelsbeheersing valt. Effectiever nog kon een toezichthoudend beheerder zijn, maar daar deed weer de 'agent-principaal'problematiek zich gevoelen. In ieder geval, als arbeiderswoningbouw werd gebruikt als beheersingsmiddel gebeurde dit ter verhoging van culturele beheersing, onder het 'motto' vreedzaamheid, kuisheid en matigheid. 
Als beheersing de voomaamste reden tot het aanbieden van huisvesting is geweest, kan men dit als éen blijk van een paternalistische stijl zien. Woningbouw kan nooit een uiting van een liberalistische beheersstijl zijn, want deze betreft alleen aktiviteiten en resultaten die aan produktie kunnen worden gerelateerd. Als uitsluitend commercielle motieven - het profijtelijk verhuren van arbeiderswoningen - speelden, mag men hooguit de concluderen dat de paternalistische beheersing een welkom neveneffect is van deze vorm van produktdifferentiatie.

Ook Petrus Regout heeft woningbouw als wervings-, behoud- en beheersingsmiddel toegepast. Om te kunnen bepalen of zijn initiatieven van een paternalistische beheersstijl getuigen of een vorm van produktdifferentiatie met paternalistische externe effecten zijn, is het nodig soortgelijke initiatieven in zijn omgeving tegen het licht te houden. Heeft men zicht op hoe industriële entrepreneurs met een vergelijkbare achtergrond en waardenpatroon een en ander hebben aangewend, dan wordit het gemakkelijker Regout's motieven in te schatten.

Van Regout's huisvestingsinitiatieven is het meest bekend (en berucht) zijn woonkazerne de Cité Ouvrière geworden. Deze 'Groete Bów', gebouwd in 1863 en een jaar later in gebruik genomen, was, naar Maastrichtse begrippen, inderdaad een groot gebouw. 'Groot' will vooral zeggen: hoog en diep (beide ca. 35 meter); de breedte was een 25 meter. De zeven verdiepingen (waaronder een zolderverdieping) bevatten 72 één-kamerwoningen, twaalf per verdieping, zes aan weerskanten van een gemeenschappelijke gang; verder 24 zolderkamertjes, 16 voor mannen en vrouwen gescheiden privaten en een kelder, verdeeld in 36 hokken. De kamers hadden een inhoud van 60 kubieke meter. Met een heel gezin op een kamer van zes bij viereneenhalve meter waar moest worden gegeten, gewoond en geslapen: niet bepaald groot, al spreekt Regout zelf, twintig jaar later nog, in een nota aan de commissie de Vries Robbé, die met het onderzoek naar kinderarbeid was belast, van 'zeer aanzienlijke en ruime arbeiderswoningen' (Archief Petrus Regout, Contractenboek nr. 26, p. 309). Niettemin moet worden bedacht dat de gemiddelde huurkamer in de krottenwijken van de Maastrichtse binnenstad nóg kleiner was: tussen de 30 en 50 kubieke meter (zie verderop). Per verdieping was er in de Cité een waterpomp, een voorziening waar de meeste bewoners van genoemde huurkamers het eveneens zonder moesten stellen. Over de voorziening van de lijkenkamer, in de zijvleugel van de Cité, is veel gesmaald ${ }^{27}$, maar de waterpomp was in ieder geval een aanmerkelijke vooruitgang, want ook

27 '...] Regout waakte over leven en dood zijner onderhoorigen, weshalve hij in de 'Groete Bouw' ook een doodenhuis liet inrichten. De dood was immers de trouwste bondgenoot van dezen beroepsuitbuiter' (Ubachs, 1976: 40). 
drinkwater was voor de meeste bewoners van de huurkazernes rond de Stokstraat en Raamstraat onbekend.

Eveneens een onmiskenbare vooruitgang ten opzichte van de woningen in de naaste omgeving was het feit dat de kamers nieuw waren. Dus: aanmerkelijk minder vochtig. Dus: minder ziektes. Dat zou men kunnen afleiden uit het feit dat de cholera-epidemie van 1866 in de dichtbevolkte StAnthoniusstraat (met 845 bewoners ná de Raamstraat, waar 879 mensen. woonden, de dichtstbevolkte van de buurt) betrekkelijk ongemoeid liet: negen overledenen, tegen 42 in de Raamstraat en 35 in de kleine Koekscihroefstraat. $^{28}$

Het materiaal dat in de Cité werd gebruikt, moet van een redelijke kwaliteit zijn geweest. De vloeren van de kamers en gangen waren belegd met 'roode en blaauwe Hollandsche plavuizen'. De wanden waren bepleisterd (Archief Petrus Regout, Contractenboek 26, pp. 118-20). Opnieuw: een vooruitgang, al lijkt Regout's kwalificatie in genoemde nota van de kamers als 'zeer gezonde en zindelijke woningen' overdreven, als men alleen al denkt aan het gebrek aan licht en lucht, en aan het geringe aantal privaten: van één privaat moesten 15 tot 20 mensen gebruik maken. Het hoeft geen verbazing te wekken dat de commissie De Vries Robbé vond dat de privaten 'nog al veel stank' verspreidden (Rapport, etc., p. 902). De ruim zeventig gezinnen, tezamen zo'n 250 à 300 personen, konden slechts over één centrale ingang beschikken. Burenruzie in de gangen en op de trappen moet veelvuldig zijn voorgekomen, ondanks de conciërge die door Regout was aangesteld om toezicht te houden en de orde te bewaren.

28 Schema (Bron: Gedenkboek, 1959: 106) 1866

Antoniusstr. Grachtstr. Gubbelstr. Raamstr.

$\begin{array}{lrrrr}\text { aantal huizen } & 36 & 30 & 35 & 35 \\ \text { aantal personen } & 259 & 283 & 280 & 317 \\ \text { gen. aantal } & 7,2 & 9,4 & 8 & 9 \\ \text { pers. p. huis } & & & & \\ \text { \% huizen met 1 gezin } & 36 & 20 & 31 & 15 \\ \text { met } 2 \text { gezinnen } & 40 & 53 & 44 & 53 \\ \text { met } 3 \text { gezinnen } & 14 & 23 & 17 & 17 \\ >\text { gezinnen } & 5 & 3 & 8 & 15 \\ \text { onbekend } & 5 & 1 & - & -\end{array}$

Ter vergelijk: in de Stokstraatbuurt was het gemiddeld aantal personen per huis in 1835: Plankstraat 11; Stokstraat 7; Havenstraat 9; Houtmaas 7,8 (Bron: ibid., p. 109). 
Ook de huurprijs lijkt voor de inwoners gunstig af te steken tegen die in de gewone huurkazernes. De huur varieerde van 70 cent per week voor een kamer op de benedenverdieping tot 40 cent voor een kamer op de vijfde verdieping. Per jaar is dat respectievelijk $f 31,20$ en $f 41,60$. In het rapport van de commissie De Vries Robbé staat dat, volgens een andere industrieel in de stad, de huur in de arbeidersbuurten voor één kamer 60 tot 80 gulden bedroeg. Als die cijfers kloppen, waren de bewoners van de Cité aanmerkelijk goedkoper af. Daar stond wel een groot nadeel tegenover: Petrus Regout trok de huur van het loon af. De consequentie laat zich denken: ontslag (genomen of gekregen) betekende ook ontruiming van de Cité - een krachtig ontmoedigend behoudmiddel. ${ }^{29}$

De stedelijke context is niet het enige kader dat inzicht kan verschaffen in de motieven achter dit initiatief. Men kan Regout's Cité ook tegen de achtergrond plaatsen van huisvestingsinitiatieven van andere fabrikanten. De context van Maastrichtse fabrikanten heeft hier weinig zin: in de decennia dat Petrus Regout aktief was, hebben deze niet of nauwelijks iets op dit gebied ondernomen. Beter dan alle Westeuropese fabrikanten in dit tijdvak te nemen, is een vergelijking met fabrikanten uit de niet te wijde omgeving. Daarmee worden belangrijke variabelen (zoals religie) constant gehouden, terwijl toch genoeg kan worden geabstraheerd van de specifieke lokalle situatie.

Omdat in het vorige hoofdstuk is gewezen op sociaal-culturele en institutionele mogelijkheden en belemmeringen van het werven, behouden en beheersen van arbeid, krijgt de 'middelwijde context' hieronder wat meer aandacht. Deze context strekt zich dan uit van, noem het, 'wereldbeeld ter zake' tot de concrete woningbouwinitiatieven van fabrikanten die Regout tot voorbeeld hebben gestrekt of hadden kunnen strekken.

Wat ook fabrikanten heeft bewogen hun aktiviteiten uit te strekken tot huisvesting van hun arbeiders, deze initiatieven kunnen niet los worden gezien van (a) de woningnood aan het eind van de achttiende en het begin van de negentiende eeuw en (b) de speculatiebouw die in de pas geindustrialiseerde gebieden een grote omvang aannam.

(a) De bevolkingstoename in West-Europa is in het vorige hoofdstuk genoemd. Het waren de steden waar het dalende sterftecijfer het meest manifest was. Niet alleen nam de bevolking daar krachtig toe, er trokken ook steeds meer mensen van het platteland naar de steden, omdat de

${ }^{29}$ De Jonge's conclusie lijkt gerechtvaardigd: '(..) een woonkazerne, die vergeleken met wat krottten konden bieden wel een stap vooruit was, maar - in de ogen van het nageslacht terecht - geen navolging vond" (1976: 198). 
vraag in de landbouw niet het grotere aanbod van arbeid kon bijbenen, zeker niet na de grote herverkavelingen van die tijd.

In Maastricht woonden er in 183026.330 inwoners (volgens Maenen 22.000). Dat was een aanmerkelijke vooruitgang ten opzichte van de Franse tijd, toen er nog slechts 17.000 mensen in de stad woonden. Maar in 1860 was het inwonertal slechts gestegen tot 29.147 (vgl. de cijfers bij Maenen: 28.740 in 1869) en in 1890 slechts tot 34.971 (vgl. Maenen: 34.305 in 1900) (Van Doom, 1945a: 6). Ondanks de slechts matige stijging van het inwonertal in de periode 1830-1890 was de woningnood in de volksbuurten groot. De bevolkingsstijging dié er was, kon bijna volledig op rekening van de arbeidersklasse worden geschreven. Bovendien kromp het garnizoen van 6 a 7.000 man ten tijde van de Belgische Opstand tot ongeveer 1000 man in het begin van de jaren zestig en hebben in de jaren dertig veel middenstanders en in de jaren zestig en zeventig veel welgestelde families de stad verlaten. De eersten omdat zij door de opstand hun nering ten onder hadden zien gaan; de tweeden onder meer omdat deze renteniers zich in de geindustrialiseerde stad niet meer thuis voelden. 'Alle vermogende personen hebben Maastricht verlaten,' staat het - gechargeerd - in het rapport van de Parlementaire Enquête van 1887 (vraag 7360)(herdrukt in: Giele, 1981).

Door de bevolkingsaanwas en de ruraal-urbane migraties ontstond er in veel Westeuropese steden (waaronder dus ook Maastricht) een fors arbeidspotentieel, waarmee werd voldaan aan een kernvoorwaarde voor de Industriële Revolutie, die immers niet had kunnen plaatsgrijpen zonder concentraties van mensen die bereid waren of zich genoodzaakt zagen in fabrieken te werken. En naarmate de industrialisering zich uitbreidde, nam ook weer de immigratie naar de stad toe. Al vlug kon de huisarbeid, waar rendementsverbeteringen amper mogelijk waren, de concurrentiestrijd met de fabrieken niet meer volhouden - wat eveneens opnieuw weer de trek naar de steden deed toenemen. ${ }^{30}$

Zoals in het geval van Maastricht al duidelijk werd, bracht de concentratie van autochtone en allochtone werkers en werkzoekenden in de

30 Ook hier zien we dat te weinig recht wordt gedaan aan de gecompliceerdheid van dergelijke maatschappelijke processen als er een causale relatie in welke richting dan ook wordt gelegd tussen enerzijds industrialisering en anderzijds bevolkingsgroei en trek naar de steden. Het één versterkte het ander en omgekeerd. Stilistisch is het echter moeilijk de verwevenheid van dergelijke ontwikkelingen te laten zien, want door één proces het eerste te noemen, wekt men toch de suggestie dat dit proces de wèrkelijke oorzaak is. Bovendien roept men snel de hulp in van tamelijk loze wendingen als 'samenhangen met' en, zie hierboven, 'zijn verweven met'. Daarmee is vaak de kous af: de tevredenheid over het feit dat het juiste werkwoord is gekozen, maakt blind voor de noodzaak te beschrijven en interpreteren hoe het meer precies ging. 
steden grote huisvestingsproblemen met zich. Al was de woonsituatie op het platteland waarschijnlijk nog beroerder, de nijpende vraag bleef: waar en hoe moesten al deze nieuwkomers onderdak vinden? De volksbuurten in de stad waren toch al overbelast door de eigen aanwas.

(b) Speculatiebouw. Vóór 1850 woonden in (Noord-)Nederland veel armen in uitgewoonde, verlaten burgerwoningen. Ondanks de grote woningnood werden nauwelijks huurwoningen gebouwd (Brugmans, 1970: 157). Maar in België nam, ondanks het feit dat ook daar velen in voormalige burgerhuizen woonden, nieuwbouw voor arbeiders in een veel vroeger stadium een vlucht. Het initiatief ging uit van mensen die in de vrije beroepen werkzaam waren, of renteniers. De volkswoningbouw was cen interessante belegging: dankzij de woningschaarste kon de huurprijs hoog worden gehouden, zodat de investeringskosten, toch al tot een minimum beperkt, in enkele jaren waren terugverdiend.

Kostenbesparing werd gezocht: i) door het opvoeren van de bebouwingsdichtheid, zodat de grondprijs zo weinig mogelijk hoefde te drukken en ii) door de woningen zelf zo klein mogelijk te houden en zo goedkoop mogelijk materiaal te gebruiken. Zo ontstonden bij de fabrieken twee hoofdvormen van speculatiebouw in de Belgische steden: de 'kwartierwoning" en de 'beluiken".

Van buiten leek de kwartierwoning op de gewone burgerwoning. Van binnen waren deze woningen echter opgesplitst in kleine, apart verhuurde vertrekken - net zoals in de uitgewoonde en verlaten èchte burgerwoningen. Het gemiddeld aantal inwoners in een dergelijke woning van voor de burgerij gemiddelde - afmeting was ongeveer honderd. De beluiken, ook wel 'gangen' of 'fortjes', bestonden uit éen of meer rijen gewoonlijk identieke huisjes, met ten hoogste één verdieping, op een binnenterrein dat via een gemeenschappelijke toegang werd betreden. Er werd steeds gestreefd naar een maximum aantal huisjes in een rechthoek binnen de gegeven ruimte. ${ }^{31}$ Zo werden de huisjes met de ruggen tegen elkaar gebouwd - een bekend verschijnsel in geindustrialnseerde streken. Alleen de voorkant bleef vrij; in het beste geval keek men uit op het binnenerf, in de meeste gevallen echter op de voorkant van een andere woning. Op dat bimenerf bevond zich doorgaans het gemeenschappelijke sanitair en de waterpomp. In Gent zijn in de eerste helft van de negentiende eeuw veel van deze arbeiderswoningen gebouwd..$^{32}$

31 Die rechthoek werd nagestreefd in verband met de dakconstructie, die op deze wije het goedkoopst uitviel.

32 Een beschrijuing van de Gentse Sociate de Médicine van het beluik Batavia, in 1848 door Charles Leclerc-Restiaux gebouwd tussen de Rozier en het St. Pietersplein: 'De ingangen hebben de breedte van een gewone deur en kumen gemakkelijk verward worden met de toegangsdeuren van de omringende 
Velen trokken naar de stad in de mening dat de behuizing moeilijk slechter kon zijn dan die op het platteland. Men kon inderdaad beter in een beluikhuisje wonen dan in een plattelandsonderkomen. Maar door de grotere woondichtheid waren er problemen die op het platteland minder zwaar wogen: de opeenhoping van huisvuil en uitwerpselen, het gebrek aan licht, lucht en privacy. Daarbij waren deze beluiken onttrokken aan de gemeentelijke bouwcontrole: tot 1844 hoefden alleen de plannen voor de stratgevels ter goedkeuring worden voorgelegd.

Zo groeide in steden als Gent en Mechelen een stad binnen de stad, verscholen achter vaak indrukwekkende straatgevels, die pas bij nadere inspectie een deur bleken te bezitten die toegang gaf tot een binnenterrein. Zo leefde éen-derde van de Gentse bevolking op een oppervlakte niet groter dan drie procent van de totale oppervlakte van de stad (Smets, 1977).

De vroegnegentiende-eeuwse Vlaamse speculatiebouw herkent men in Maastricht, zij het een paar decennia later en op bescheidener schaal. De huizenvoorraad in Maastricht is in het eerste drie-kwart van de negentiende eeuw nauwelijks toegenomen. In 1851 telde de stad 2719 woonhuizen. Dat aantal werd ook al in 1777 geregistreerd en is in de tussenliggende periode nagenoeg gelijk gebleven. Na 1851 nam het aantal woonhuizen, na een korte stijging tot 2807 in 1859, zelfs af tot 2597 in 1879.

Vóór 1850 is speculatiebouw in Maastricht vrijwel onbekend. Cornips schrijft in zijn geschiedenis van de Maastrichtse bouwvereniging St. Servatius (1952) dat het meer dan waarschijnlijk is dat in de eerste helft van de eeuw ook in Maastricht de arbeidersgezinnen slechts onderdak vonden in

woningen. Het beluik is 100 meter lang op gemiddeld 30 meter breed, is samengesteld uit 117 woningen en omvat vier straatjes, drie parallelle steegjes en één dwarsstraat. De huisjes die er aanpalen zijn zo ingeplant dat elke woning die aan de voorkant uitziet op een steegje, langs achter is aangebouwd tegen een woning die uitziet op het volgende steegje. Die steegjes zijn 2,70 meter breed. Ze worden gebruikt als koer. In hun as stroomt een open riool, terwijl er koorden van gevel tot gevel zijn gespannen om het linnen te drogen. Men telt er zes latrines en twee waterpompen, die door de hele bevolking moeten gebruikt worden.

'In totaal wonen 585 bewoners in dit beluik, zodat iedereen gemiddeld over 3,40 vierkante meter terrein beschikt, wat erger is dan wat we elders ooit aangetroffen hebben, want in Parijs en Lille, in de Quartier des Marchés en de Quartier des Arcis, waar de bevolking gemiddeld over minder ruimte beschikt dan in alle andere wijken, heeft elkeen nog gemiddeld 8 vierkante meter ter beschikking.'

[..] Wij schatten de waarde van de woningen in het beluik Batavia in totaal op maximum 40.000 lrank, inbegrepen de waarde van het terrein. Het volledig belwik brengt jaarlijks 7.280 frank op, waarvan 280 frank moeten worden afgetrokken als verlies voor reparatie- en onderhoudskosten. De netto-winst bedraagt dus 17 tot 18 percent!" (geciteerd in Smets, 1977; 10). 
verlaten uitgewoonde burgerhuizen, waar, door de toename van het aantal arbeidersgezinnen niet méér dan één kamer per gezin ter beschikking zal zijn geweest. Deze verlaten burgerhuizen werden bouwen' genoemd. De weinige nieuwbouw ${ }^{33}$ die er in die tijd bijkwam, waren 'de beruchte van licht en Jucht ontstoken sloppen', aldus Cornips, de 'krotten en slobjes', aldus Nafzger, die achter de burgerwoningen verrezen, in de tuinen en op andere open binnenruimten. Men zou deze sloppen ('steiweeg" genoemd) kunnen vergelijken met de Vlaamse beluiken, zij het dat er in Maastricht riet het systeem bestond zoveel mogelijk huisjes, gebouwd in een rechthoek, op zo weinig mogelijk ruimte. Ze waren wèl een stad(je) binnen stad.

De lichte stijging van het woningbestand in de jaren vijftig is misschien te danken aan het feit dat er toen wèl speculatiebouw verscheen. In de Boschstraatbuurt werd een aantal woonkazernes gebouwd, vergelijkbaar met de Vlaamse kwartierbouw. Cornips: '(...) die sombere, hoge huizen van drie verdiepingen, die we nog aantreffen in straten als de Coxstraat, de Grachtstraat en bij het Bassin' (1952: 15) Deze huizen waren bestemd voor zes à twaalf gezinnen, naar gelang het enkele of dubbele huizen waren. Wie heeft deze huizen (eveneens bouwen' genoemd) gebouwd? Cornips meent: Met een grote mate van waarschijnlijkheid is wel te zeggen, dat het de industriëlen zullen zijn geweest, die op deze wijze het steeds toenemend aantal arbeiders huisvesting verleenden' (ibid., p. 15). Roemen neemt dit ook aan (1947: 323). Heeft Regout deze panden gebouwd? In het werkje Carrière de Monsieur Petrus Regout (Maastricht, 1869) wordt gewag gemaakt van een aantal woningen in de St. Anthoniusstraat, de Raamstraat en op de Maagdendries dat door hem in de jaren vijftig zou zijn opgekocht en ingericht voor bewoning door zijn arbeiders. Opgekocht, staat er. Als andere fabrikanten deze kwartierbouwen hebben gebouwd, is dat waarschijnlijk Lhoëst-Lammens van de nabije papierfabriek geweest.

\section{Fabrikanteninitiatieven}

Vaamse kwartierbouw en beluiken herkent men niet alleen in de Maastrichtse speculatiebouw, maar ook in latere woningbouwinitiatieven in de hele Zuidnederlandse regio die niet in eerste instantie met speculatieoog-

33. Gezien de gelijkblijvende huizenomvang vóór 1850 kunnen het er niet veel geweest, aangenomen dat elders in de stad niet een groot aantal huizen verdween. Maar het beeld kan vertekend zjjn omdat deze sloppen misschien niet werden meegeteld. De Maastrichtse sloppen, die zich bijna allemaal in de Boschstraatbuurt bevonden, met name achter de Raamstraat en Grachtstraat, zijn niet zozeer de vruchten van vooropgezette speculatie; wat weer niet wil zeggen dat er door de eigenaren - zelf de buurt ontvlucht - niet goed op werd verdiend. 
merken zijn gebouwd. Onbedoeld zijn de speculatiewoningen een voorbeeld geweest voor latere initiatieven - van woningbouwverenigingen, gemeentelijke overheden en andere publieke instellingen - met een hoger filantropisch gehalte, gunstiger huren en meer comfort. 'Hun (dat van de speculanten, avi) ingrijpen is maatgevend geweest voor de ontwikkeling van het denken over de volkshuisvesting en dit zowel in de negatieve als in de positieve zin. Enerzijds zullen wetten worden uitgevaardigd die tot doel hebben de voor de betere bevolkingsgroepen schadelijke nevenaspecten van de speculatiebouw (epidemieën en sociale onlusten) tegen te gaan, maar anderzijds zal de volkshuisvesting, in de concepten die deze bezwaren moesten ondervangen, steeds als beleggingsobjekt worden benaderd. Dit had tot gevolg dat de huizentypes en de woninginplantingen die in de spekulatiebouw ingang hadden gevonden, in de voorstellen die tegen de speculatiebouw gericht waren, zouden blijven gehanteerd worden, schrijft Marcel Smets in De ontwikkeling van de tuingedachte in België (1977: 12). . $^{34}$

Ook fabrikanten lieten zich in hun arbeidershuisvesting deels leiden door standaarden die speculanten hadden ontwikkeld. Het beluiksysteem kan men herkennen in de meeste door fabrikanten gebouwde arbeiderswoningen in de Waalse kolen- en ertsmijnbouw ${ }^{35}$, maar ook in de cité ouvriere bij de Val St.-Lambert, Regout's leverancier en latere concurrent.

${ }^{34}$ Deze stelling kan men in een navranter vorm herkennen in Lewis Mumford's The city in history (1979). Mumford ziet in de loop van de negentiende eeuw een neerwaartse beweging in het bouwen en huisvesten ten behoeve van arbeiders. Deze beweging - volgens de schrijver te wijten aan een eenzijdige preoccupatie met rente en winst - is zelfs zichtbaar in filantropisch bedoelde initiatieven. 'When the first model housing was introduced by a charitable group in New York, in the eighteen-fifties, the plan, as a matter of course, produced inside rooms that had no light except from a window opening on an outside room. Even in terms of the mean offerings to the underpaid workers then current, this model tenement proved so vile that it soon became the favoured resort of thieves and prostitutes' (Mumford, 1979). Ook bij de bekende vier tot vijf verdiepingen hoge Peabody Buildings in Londen - een veel nagevolgd filantropisch initiatief uit de tweede helft van de eeuw - treft men een minimum aan licht, lucht en sanitair aan. De open ruimte tussen de flats was van muur tot muur geplaveid; kinderen mochten er niet spelen.

35 "De 1830 à 1850 , on érigera un nombre considérable de ces petites maisons dans les centres de charbonnage et d'établissements minéralurgiques. Elles étaient destinées aux ouvriers attachés à les exploitations et les industriels se préoccupaient seulement de les conserver à leurs établissements,' schreef $\mathrm{H}$. Royer De Dour in Les habitations owwières en Belgique (1890). De vergelijking met de arbeidershuisjes in het rurale Engeland dringt zich op. 
Regout's eigen Cité is te bestempelen als een vorm van kwartierbouw: een groot aantal huurkamers dat de suggestie wekt één huis te zijn.

Maar eerst moet de vraag worden beantwoord hoe belangrijk fabrikanteninitiatieven op het gebied van arbeiderswoningen waren in de decennia voor 1850 (tol aan het bouwen van de Maastrichtse Cité). In één zin: in de eerste decennia van de industrialisering hebben fabrikanten zich weinig onderscheiden door aktiviteiten ten behoeve van huisvesting van hun arbeiders. $^{36}$ In het verlaat geindustrialiseerde Nederland zijn er vóor 1850, zoals opgemerkt, nauwelijks arbeiderswoningen gebouwd, dus ook niet door fabrikanten. Wèl kan er op een initiatief worden gewezen van de Maatschappij van Weldadigheid (zie ook \& 6). In 1835 werden in Leiden door deze filantropisch bedoelde instelling 33 werkmanswoningen gebouwd. Maar dit wond nauwelijks navolging. Na 1850 verschenen hier en daar womingbouwprojekten, opgezet door fabrikanten. In 1852 bouwde de Nijverdalse fabrikant Salomonson 80 woningen voor de arbeiders van de stoomweverij. ${ }^{37}$ In 1856 werden er ook in Almelo woningen voor arbeiders gebouwd. In Arnhem lieten de fabrikanten Noppen en Coers een aantal woningen bij hun bedrijf bouwen (Brugmans, 1970: 161; Camijn, 1987).

Regout's Cité, met zijn zeventig kamers in één gebouw, was naar Nederlandse begrippen een nooit eerder vertoond fenomeen, dat ook geen navolging heeft gezien. De 'Groete Bouw' is een incident geweest, zoals ook de gevelversiering - in architectonisch opzicht - een incident is gebleken (zie de volgende \$). Maar voor Petrus Regout is deze woonkazeme géén incident geweest: het paste in zijn stijl.

Omdat Maastricht en ook haar inwoner Petrus Regout meer op het zuiden dan het noorden was georiënteerd, is het zinniger vergelijking te zoeken met woningbouwinitiatieven van Belgische industriëlen. In Vlaanderen en Wallonië zijn fabrikanten decennia eerder begonnen met het bouwen van voor arbeiders bestemde woningen, al woonde - met name in de Vlaamse steden - een belangrijk deel van de fabrieksarbeiders in uitgewoonde en verlaten patriciérswoningen en in de door speculanten gebouwde beluiken en kwartierwoningen, met welke initiatieven diende te worden 'geconcurreerd".

Een van de eerste fabrikanten die hier aktief werden was opnieuw de Gentenaar Lieven Bauwens. In het begin van de negentiende eeuw wilde

36 Arbeideswoningbouw geinitieerd door de overheid bestond in die decennia vrijwel niet.

37 Hett uitwoerig woningbouwplan dat Ainsworth, de eerste stichter van Nijverdal, al in 1834 had opgesteld is nooit uitgevoerd. 
hij rond zijn katoenspinnerij in de (in de Franse tijd ontruimde) abdij van Drongen, buiten de stad, een arbeiderswijk bouwen, waarschijnlijk met de bedoeling arbeiders aan te trekken. Dit plan heeft hij niet helemaal tot uitvoer gebracht. In 1837 bouwde de firma Voortman - om een ander voorbeeld uit Gent te nemen - dertien arbeidershuisjes in het Berouw, vlak bij het bedrijf. Dit initiatief wordt gunstig gewaardeerd in de Inventaris van het Belgische cultuurbezit: "Uit dit voorbeeld, en enkele andere (...), blijkt dat deze door de fabrikanten opgetrokken woningen van betere kwaliteit waren dan de doorsnee, mogelijk als gevolg van een zeker paternalisme, mogelijk om de arbeiders (of bepaalde arbeiders?) aan het bedrijf te binden" (Inventaris van het cultuurbezit in België, Architectuur, deel $4 \mathrm{nb} \mathrm{N}-\mathrm{O}$ Stad Gent, 1975).

Voor de meeste Vlaamse en Waalse fabriekscités gold dat de arbeiders er beter af waren dan in de beluikenhuisjes en de kwartierwoningen, waar ze naar vorm sterk op leken. Dit is conform de veronderstelling dat fabrikanten méér comfort moesten bieden dan wat de eerder op de markt getreden speculanten boden.

Drie projekten uit de begintijd van de Zuidnederlandse Industriële Revolutie kunnen als klassieke voorbeelden van filantropische initiatieven gelden. Het zijn de arbeiderwoningcomplexen bij de kolenmijnen van Boisdu-Luc, Mariemont en Grand-Hornu. De cité van Bois-du-Luc - Cité de Bosquetville geheten - is in 1836 gebouwd en bevat 166 woningen, een school, winkels en een verpleeginrichting (Roelants du Vivier, 1973). De cité van Mariemont, bij Thuin, bestaat uit twee complexen van tezamen een zestig woningen, de Cité d'Olive en de Cité Ste.-Cathérine geheten; ze zijn gebouwd in 1856 in opdracht van Nicolas Warocqué, die aan het hoofd stond van de mijnmaatschappij 'L'Olive \& Chaud Buisson' (Patrimonium 10-2, Thuin: 629). De cité van Le Grand-Hornu behoort tot de bekendste ter wereld. Dat is niet de enige reden waarom ik erop terugkom; het is ook omdat deze cité duidelijk maakt dat zelfs bij een huisvestingsinitiatief dat louter door filantropische motieven lijkt te zijn ingegeven eigenbelang niet afwezig is.

Enkele decennia vóór de Le Grand-Hornu kwam in Verviers een arbeiderswoningprojekt tot stand, bekend onder de naam 'Grandes Rames'. In 1808 werd op initiatief van de wolfabrikanten Jean-François Biolley en Henri-Guillaume Simonis begonnen met de bouw van appartementen in de Rue des Grandes Rames en de Rue des Hospices, aan de rand van de stad. Daarmee werd het reeds van 1792 daterende voorstel van de fabrikant R. Godard uitgevoerd. Verviers was al an het einde van de achttiende eeuw door de toestroom van arbeidskrachten, voornamelijk afkomstig van de omliggende dorpen, overbevolkt geraakt. Er was een ernstig huisvestingsgebrek voor deze nieuwkomers (Le Brun, 1948). De 'Grandes 
Rames' bestaat uit twee parallelle rijen van vijf appartementen, vier verdiepingen hoog. Elk appartement bevat zestien woningen, vier per verdieping, aan weerskanten van het trappenhuis. In total woonden er dus 160 gezinnen. Hun woningen bestonden uit twee kleine kamers, waarvan er één een Iaam had. De 'Grandes Rames' was een van de eerste voorbeelden van $k$ wartierbouw - misschien het allereerste.

Een ander vroeg voorbeeld van een woningbouwprojekt in de omgeving van Maastricht is al genoemd: de beluik-achtigé cité ouvrière bij de Val St. Lambert. Het is een minder bekende cité, maar wèl een die Petrus Regout vrijwel zeker zelf heeft gezien, omdat hij er van 1826 tot 1835 ongeslepen glas kocht (Maenen, 1959: 180). Deze cité had hem tot voorbeeld kunnen strekken.

Kemlin en Lelièvre trokken hun eerste geschoolde arbeiders aan uit Engeland en uit de glasfabriek van Vonêche in de Ardennen, waar beiden hadden gewerkt. Om deze vakarbeiders te werven, bouwden de oprichters 'een cité voor de arbeiders, woningen voor de beambten en villa's voor het hoger leidinggevend personeel' (GAL-bulletin, 1987: 14). Van die betere woningen en villa's heb ik echter in andere literatuur niets kunnen vinden (Le Patrinoine monumental de la Belgique, volume 8, Province de Liege, Arondissement de Liegge, tome $2(\mathrm{~L}-\mathrm{V}), 1975)$. De eerste arbeiderswoningen werden gebouwd als een driehoekig complex gelegen tegenover een zeventiendeeeuws gastenverblijf van de abdij. Deze eerste serie, woningen met éen verdieping, moet in het tweede kwart van de vorige eeuw zijn gebouwd. De tweede reeks arbeiderswoningen, eveneens een driehoek vormend, is van latere datum, maar misschien ook nog van vóór de Maastrichtse cité. Aanvankelijk woonden er per woning vier gezinnen, die elk de beschikking hadden over twee kamers en een toilet. Later woonden er nog maar twee gezinnen per woning. Er was geen stromend water in de huizen; men moest gebruik maken van de gemeenschappelijke waterpompen in het midden van de driehoek. Deze cours werden beplant met lindenbomen.

Door de besloten vorm van het complex, de waterpompen en de bomen, en ook door de vriendelijk ogende huisjes, met licht gewelfde raamuitsparingen, werd deze cité vaak 'het begijnhof' genoemd. Bij de ingang van de cité staat een wachtgebouwtje (het abdijcomplex is geheel ommuurd) vanwaaruit het gaande en komende verkeer in de gaten werd gehouden, alsmede het leven op de cité zelf, dat inderdaad een haast kloosterlijk karakter droeg. In een in 1895 geschreven boekwerkje over de Val Saint-Lambert wordt opgemerkt dat het aantal arbeiders dat in de cité is geboren en de vijftigjarige leeftijd heeft bereikt zonder een voet buiten het fabriekscomplex te hebben gezet, groot is (Benard, 1895).

In 1835 reeds ging de Val, zoals de fabriek wordt genoemd, van start met een eigen school: een kleuterschool en lagere school voor kinderen van het personeel; beide waren gratis. Dit initiatief ligt in dezelfde lijn als 
de woningbouw: beide moeten zijn geinitieerd omdat er in Seraing een gebrek aan deze voorzieningen bestond. Toen er in 1873 wèl een school in deze voorstad werd geopend, werd die op het abdijcomplex ook opgeheven. Buiten de lagere school was er nog een tekenschool, die inwoners opleidde voor de ontwerpafdeling, alsook een zang-en muziekschool, een huishoudschool en een handelsschool. Maar het is niet duidelijk hoeveel gewicht aan deze termen - 'muziekschool', 'handelsschool' - moet worden gegeven.

Uit deze voorbeelden mag men concluderen dat in de context van andere huisvestingsinitiatieven van fabrikanten in de relevante omgeving in Regout's Cité Ouvrière een benedengemiddeld wooncomfort werd aangeboden en een bovengemiddelde huurprijs gevraagd. Dit gegeven mag iets zeggen over het commerciële dan wel filantropische gehalte van dit initiatief. Ik kom daarop terug.

Regout heeft de Cité niet gebouwd als attractiemiddel, want de aanbod van ongeschoolde arbeid was voor hem nauwelijks een probleem en geschoolde arbeiders woonden er niet. Of Regout de Cité wèl als bemoedigingsmiddel heeft aangewend, is niet geheel onwaarschijnlijk. In de stedelijke context immers stak deze huisvesting naar prijs en comfort gunstig af. Dat Regout de Cité heeft gebruikt als restrictiemiddel lijdt geen twijfel, want ontslag betekende óók ontruiming van de Cité - en dat in een stad met hoge woningnood en ongunstige woonomstandigheden.

De Cité Ouvrière heeft méér dan enig ander middel gediend als beheersingsinstrument. Van huisinspecties, als vorm van action control buiten de werkvloer, is uit de bronnen niets bekend, maar onwaarschijnlijk is het zeker niet; al moet gezegd dat een belangrijke aanleiding tot inspectie huurinning - niet kon worden aangegrepen omdat Regout, als gezegd, de huur van het loon aftrok. Maar de veel effectiever geachte permanente controle van een conciërge is wèl gedocumenteerd. ${ }^{38}$ Met diens toezicht op het sociaal verkeer en de hygiëne werd een verhoging van culturele beheersing - vreedzaamheid, kuisheid en matigheid - nagestreefd.

Doordat - gelet op het feit dat de huren in de Cité lager waren dan in de omringende arbeiderswoningen, waardoor het winstmotief onwaarschijnlijk wordt - dit initiatief in de eerste plaats als een vorm van beheersing moeten worden gezien, moeten we hier (waar géen sprake is van

38 In het enquêterapport van de staatscommissie De Vries Robbé staat: 'Men beweert dat de Cité Ouvrière slecht is ingerigt, dat de huurprijzen te hoog zijn en dat dit zamenwonen van zoo vele gezinnen in éen huis, èn nadelig is voor de zedelijkheid én tot dagelijksche en soms grote twisten aanleiding geeft. De heer Regout beweert, dat de portier tevens voor de goede orde zorgt, en dat de inwonenden zich zeer goed met elkander verstaan en verdragen" (in: Maenen, 1959: $67)$. 
produktie en produktiviteit, die men met aktiviteiten- en resultatenbeheersing kan proberen te beinvloeden) concluderen dat Regout, althans met zijn Cité, blijk heeft gegeven van een voorkeur voor een patemalistische beheersstijl.

\section{Ambiguiteiten ${ }^{39}$}

Hieronder zullen de (in h. 4 gesignaleerde) ambiguiteiten van de paternalistische stijl - (i) tussen commercie en filantropie en (ii) tussen strengheid en zorgzaamheid - worden herkend in de motieven van fabrikanten als Regout om arbeiderswoningen te bouwen en verhuren. Verderop wordt een derde ambiguiteit gesignaleerd: die tussen huisvesten als wervings-, behoud- en beheersingsmiddel en legitimering van deze praktijken. In $\$ 6$ van h. 4 is gesteld dat een andere belangrijke vorm van legitimering bestaat uit het 'simpelweg' uitoefenen van praktijken (in plaats van ernaar te verwijzen), waarmee het bestaansrecht zou zijn aangetoond. Deze gedachtengang wordt herkend in de Maastrichtse Cité. Daarmee kan de beschrijving van deze ambiguiteit ook worden beschouwd als een overgang naar het onderwerp legitimering.

Waar kan Regout's Cité Ouvrière - tegen het licht gehouden van een aantal belendende' initiatieven - worden geplaatst op het continuüm commercie-filantropie? Men kan stellen dat particulieren (speculanten) uitsluitend bouwden om het geldelijke gewin en dat de overheid en de woningbouwverenigingen dat meer deden uit een sociaal verantwoordelijkheidsgevoel. De motieven die fabrikanten tot het bouwen van arbeiderswoningen brachten, zijn echter minder gemakkelijk onder één noemer te brengen.

Als Regout de Cité niet in de eerste plaats als attractiemiddel heeft gebouwd, en ook commerciële motieven geen belangrijke speelden (want hij stelde zijn huurprijs onder de vigerende lokale prijs), betekent dit dat daardoor het filantropisch gehalte stijgt? Een rudimentaire vergelijking

39 Voor sommigen kan tweeslachtigheid tussen twee als oppositioneel gevoelde gedachten, gevoelens of praktijken als een paradox worden ervaren. Wie zich één tot twee eeuwen later een beeld probeert te vormen van wat industriele entrepreneurs dachten en deden, wordt misschien vaker getroffen door paradoxen. De vraag die dan verklaring verdient: waarom zagen deze entrepreneurs die paradoxen niét als paradoxen (of zagen ze het wèl zo, maar verbonden ze daar niet zo vanzelfsprekend de consequenties aan die wij misschien eraan zouden verbinden)? Om hierop een antwoord te kunnen formuleren, moet men zich proberen voor te stellen wat men ziet als men een vroeg-negentiende-eeuwse fabrikantenbril opzet. Dan kan men misschien zien dat de paradox eerder op rekening moet worden geschreven van de laat-twintigste-eeuwse beschouwer, die wèl een grote tegenstelling ziet tussen eigenbelang en filantropisch idealisme. 
met initiatieven uit de omgeving leerde dat Regout niet bijzonder werd gedreven door menslievendheid: het comfort had zonder veel moeite en kosten groter gekund. Toch kunnen beide elementen in Regout's initiatief worden herkend. Zo wijst de (in de Lage Landen weinig voorkomende) bepaling dat bij ontslag ook de woning moet worden ontruimd onloochenbaar in de richting van een welbegrepen eigenbelang, en hetzelfde geldt voor de huurprijs die van het loon wordt afgetrokken. Ook de toeziende taak van de portier kan in dit licht worden gezien. Aan de andere kant wijzen zekere signalen erop dat althans Regout ervan overtuigd was in deze uit filantropische motieven te handelen: de relatief gunstige huurprijs. en voorzieningen als de waterpompen en het lijkenhuisje.

De tweede ambiguiteit - die tussen strengheid en zorgzaamheid - wordt eveneens zichtbaar bij dit initiatief. Hoe een maatregel als het inhouden van de huur op het loon te interpreteren? Het mag zeker streng, zelfs hardvochtig, worden genoemd als een fabrikant zijn arbeiders, aan wie hij een woning heeft verhuurd, niet eens de beschikking laat de besteding van hun eigen loon te bepalen. Aan de andere kant kan men het als een daad van zorgzaamheid zien als men denkt aan het consumptiepatroon van veel arbeiders, dat van dien aard was dat er aan het eind van de maand geen geld meer over was om de huur te kunnen betalen. Op deze overweging kan men natuurlijk de vraag laten volgen: aan wie moet dit onevenwichtige consumptiepatroon worden toegeschreven? Met deze vragen begeeft men zich echter te ver in moreel vaarwater.

Om deze ambiguiteit nog wat reliëf te geven, wijd ik een alinea aan de cité ouvrière van Le Grand-Hornu, die geldt als een klassiek voorbeeld van een filantropisch initiatief.

In Hornu, ten zuid-westen van de Henegouwse hoofdstad Bergen (Mons), in de Borinage, begon in 1823 de Fransman Henri de Gorge bij zijn geavanceerde kolenmijn met de bouw van een vijfhonderd arbeiderswoningen, uitgelegd langs brede straten en om twee pleinen met fonteinen. Deze woningen waren elk twee verdiepingen hoog, met zes kamers in totaal, en voorzien van een kelder; ze beschikten over een kachel, toilet en een waterpomp (er was zelfs een mogelijkheid om af te tappen van de warmwaterleiding van de mijn); aan de achterkant was een kleine tuin. In de cité was ook een vakschool (een leermijn), een meisjesschool en een kleine bibliotheek. Verder waren er een badinrichting, een bakkerij, een danszaal, een verenigingslokaal en volkstuintjes. De gebouwen van het fabriekscomplex lagen om een groot ovaalvormig plein, versierd met alle- 
gorische standbeelden en fonteinen (Le Patrimoine monumental de la Belgique, volume 4, Province de Hainaut, 1975: 199-205; Smets, 1976). ${ }^{40}$

Hoe groot de verschillen in comfort en voorzleningen tussen de Cité Ouvrière van De Gorge en Regout zijn, het gaat te ver om te stellen dat de één werd gedreven door filantropisch idealisme en de ander door eigenbelang. Het een sluit het ander nooit helemaal uit. Elk fabrikanteninitiatief op het gebied van arbeidershuisvesting kan men op een continuüm tussen de uitersten van eigenbelang en filantropisch idealisme plaatsen. En op elke positie van dit continuüm zijn de twee hypothetische extremen "werkzaam", zij het vrijwel nooit in gelijke mate. Zo ook in Le Grand-Hornu.

Hornu lag in een weinig aantrekkelijke hoek en het was moeilijk arbeiders ernaartoe te lokken. Vandaar een 'ongehoord welzijn als lokaas' (Roelants du Vivier, 1972). In dat licht moet ook de lage huurprijs worden gezien, die circa 5,5 procent van de bouwprijs was: drie maal minder dan in het Gentse beluik Batavia. Dit welbegrepen eigenbelang ten spijt, was Le Gorge bezield van een voor zijn tijd groot filantropisch idealisme. Het 'ongehoord welzijn' en de lage huurprijs kunnen niet alleen begrepen worden uit de noodzaak arbeiders te werven en behouden. Voor minder waren ze ook wel gekomen.

${ }^{40}$ De cité van Hornu is ontworpen door de in Frankrijk opgeleide Doornikse architect Bruno Renard. Het wordt beschouwd als een goed voorbeeld van een neo-classicistisch ensemble.

De neo-classicistische beweging is ontstaan als reactie op de excessieve overdaad en ornamentiek van de late barok en het rococo. Vooral de opgravingen bij Herculaneum, Paestum en Pompeii halverwege de achttiende eeuw hebben inspirerend gewerkt. Theoretici van het neo-classicisme, zoals Abbé Laugier en Carlo Lodoli, eisten dat eenvoud, evenwicht en rationaliteit het architectonisch ontwerp moesten overheersen.

Deze architectonische moraal was ook duidelijk aanwezig in laat achttiendeeeuwse en begin negentiende-eeuwse projekten als Le Grand-Hornu. Le GrandHornu is tegelijkertijd 'l'expression d"un capitalüsme triomphant et l'apparition de préoccupations d'ordre social, caractéristiques de la classe dirigeante de ce temps' (Le patrimoine.. etc, 1975: 199). Maar deze uiting van trots en zorg wordt gepresenteerd met een uiterste soberheid aan architectonische middelen. $G$. Bekaert spreekt van 'de waardigheid en de zorg die aan de architectuur is besteed en die daardoor alleen reeds van een eerbied voor de bewoner getuigt, die ver boven die van andere arbeidswijken en industrievestigingen heengaat, en zelfs boven vele volkswoningwijken uit onze dagen' (1975: 114).

Het neo-classicisme van le Grand-Hornu moet, aldus genoemde auteur, niettemin voor de bewoners iets wezenswreemds zijn geweest, een uiting van de smaak van de hogere klassen, van de officiële cultuur. Dit contrasteert op - zo men wil haast ironische - wijze met het filantropisch karakter van De Gorge's initiatief. 
Zelfs de cite van Le Grand-Hornu is een voorbeeld van de ambiguiteit tussen eigenbelang en filantropisch idealisme, zij het dat dit initiatief op het continuüm dicht bij het laatste zal uitkomen, terwijl Regout's initiatief meer in het midden hoort.

\subsection{Regout's 'cité ouvrière' als legitimerend symbolisch artefact}

Volgens Hofstede wordt de cultuur van een organisatie uitgedrukt in symbolen, helden, rituelen en waarden. Symbolen zijn de meest oppervlakkige manifestaties van cultuur; waarden zijn het diepst verankerd in de mentale programmering waardoor de ene groep of categorie mensen van de andere wordt onderscheiden. ${ }^{41}$ Symbolen zijn het gemakkelijkst te veranderen; waarden het moeilijkst - ze zijn zelfs doorgaans onbespreekbaar. Van de vier 'manifestaties' van cultuur beschouwt Hofstede waarden als het kernelement, waaruit de andere drie - samen: de praktijken - voortvloeien (1991: 7-8). Men zou inderdaad symbolen kunnen zien als weerspiegelde waarden - maar niet àlle symbolen: het vredesteken verwijst wèl naar een waarde, de meeste getallen niet.

Symbolen wil ik definiëren als alles dat opzettelijk hets anders op een kernachtige associatieve wijze representeert. En dat 'iets anders' is in veel gevallen een waarde of een stel waarden. Symbolen zijn zichtbaar, dus materieel. Gareth Morgan definieert symbool als een fysieke expressie 'which calls for the associations of certain conscious or unconscious ideas, in order to be endowed with its full meaning and significance' (Morgan et. al, 1983: 4). Ook artefacten kunnen een symbolische functie vervullen en waarden representeren. Regout's Cité Ouvrière - een architectonisch artefact - is daarvan een instructief voorbeeld. Men kan de Maastrichtse Cité proberen te zien als de representatie van waarden, die daarmee duurzaamheid zijn gegeven. Dat hoeft niet te betekenen dat dit artefact nu zulke representatie is, maar dat men het, als men dat wilt en probeert, zo kan zién. Om heuristische redenen kam men ervoor kiezen louter voor dàt aspect aandacht te hebben. Maar dan dient zich meteen het probleem aan: hoe weet men of de symboliek met opzet is aangebracht? In veel gevallen is men bij het creëren van een artefact zich niet bewust dat men naar iets 'waardevols' verwijst. Het gaat onbedoeld - wat soms kan betekenen: onwelkom. In andere gevallen geschiedt het juist willens en wetens: de materie wordt juist 'aangegrepen' om waarden een specifieke, duurzame uit-

41 Men herkent in deze formulering Hofstede's definitie van 'cultuur' als 'de collectieve mentale vóórprogrammering die een categorie mensen van andere onderscheidt'. Voor een definitie van waarde, zie h. 4, noot 62, van dit boek. 
drukking te geven. Opnieuw kan een onderscheid dat Ervin Goffman heeft gemaakt verheldering brengen. Het verschil tussen 'signs given' en "signs given off heeft weliswaar betrekking op menselijk gedrag, maar kan ook op artefacten worden toegepast. 'Signs given' zijn 'signs we try to control": "signs given off" zijn 'signs we can't control". Bedoeld of niet, in beide gevallen wormen artefacten een waardevolle bron voor wie op zoek is naar organisatiecultuur - of naar het meer specifieke onderwerp van legitimering van wervings-, behoud- en beheersstijlen.

In de literatuur over organisatiecultuur en -symbolisme groeit de belangstelling voor symbolische artefacten - vooral architectonische artefacten. Zo heeft Edgar Schein zich verdiept in artefacten in samenhang met waarden en basisveronderstellingen (1985). Symbolische artefacten worden gezien als culturele signalen (Larsen \& Schultz, 1987; 4) of, kan men eraan toevoegen, als aanwijzingen (vgl. Ginzburg's 'clues', 1980) voor het bestaan van bepaalde, misschien verborgen, aspecten van een organisatiecultuur.

Een andere vraag die zich opdringt: wiens waarden worden gerepresenteerd? De produktie van artefacten (met symbolische functie) wordt doorgaans uitbesteed aan experts. De opdrachtgever zal zekere wensen hebben en tot voorwaarde stellen, maar de uitvoerder geniet een speelruimte juist omdat hij zich kan beroepen op specifieke kennis en vaardigheden. De uitvoerder zal zich vaak zo veel mogelijk aan de wensen en eisen van de opdrachtgever willen onttrekken om zijn eigen opvattingen en smaak te bevredigen. Hij zal zich wellicht bij een artistieke traditie willen aansluiten (of er zich juist tegen afzetten). Ook dit probleem laat zich verhelderen met het agent-principaalmodel (zie h. 1). Door de onmogelijkheid van de principaal om het werk van de agent te monitoren - als gevolg van ontbrekende expertise - , kan het onduidelijk worden naar wiens waarden de symbolen in het uiteindelijk afgeleverde artefact verwijzen.

Over de professionele uitvoerder van Regout's Cité, de Keuls-Akense architect Wilhelm Wickop (Keulen 1824 - Rhöndorf 1908), is niet bijzonder veel bekend. Hij verloor, evenals Regout, op jonge leeftijd zijn vader: toen hij vijftien jaar oud was. Ook hij werd van school genomen om in het onderhoud van zijn naasten te kunnen voorzien. Van leerling in een bouw" bedrijf werkte hij zich - via metselaarsbaas en architect bij de Keulse gemeentewerken - op tot medewerker van Ernst Friedrich Zwirner, die de opdracht had gekregen de nog steeds niet voltooide gotische Dom af te bouwen. Wickop was een echte selfmade man.

In 1856 vertrok Wickop naar Krefeld en daarna naar Berlijn, waar hij het examen voor 'Zeichen- und Gewerbeschullehrer' aflegde. Dit leverde hem een baan op als teken- en bouwconstructieleraar aan de Akense 'Provinzialgewerbeschule', waar hij tot 1894 bleef en die hij verliet met de 
officieuze titel van "Professor'. In het dorp Rhöndorf aan de Rijn stierf hij op 84-jarige leeftijd, vrijwel vergeten (Pützer, 1908).

Wickop heeft veel gebouwd: allereerst in 1862 de Akense synagoge, een gebouw dat paste in het neo-riëntalisme zoals dat in het Rijnland en in heel Duitsland gestalle aannam (Janluz, 1924; Gatz, 1971: 574 e.v.), voorts de grote concertzaal van het Akense Kurhaus, alsmede diverse kerken, scholen, fabrieken en woonhuizen, verder het slot Eberburg en verschillende villa's in de omgeving van de stad ten behoeve van de industriële elite. Veel daarvan heeft de oorlog niet overleefd.

Wickop was ook bekwaam op het vlak van de kunstnijverheid (hij ontwierp zilver- en goudwerk) en het illustreren. Hij verzorgde afbeeldingen voor uitgaven over Middeleeuwse kunst. Maar beklijvende roem hebben zijn scheppingen hem niet opgeleverd. Het was anders gelopen als hij de ontwerpwedstrijd voor de Berlijnse Dom had gewonnen. Hij kwam echter niet verder dan een troostprijs van 1500 mark.

Het komt mij voor dat Wickop zijn beste jaren beleefde toen hij in de schaduw van Zwirner en de steeds hoger rijzende Domtoren mocht werken. Het Keulen van rond 1850 was een centrum van bouwkunst. De afbouw van de Dom had een grotendeels romantische belangstelling voor de middeleeuwen ontketend. In de Rijnlandse architectuur kreeg het Schinkeliaanse classicisme (bijvoorbeeld de Elisenbrunnen in Aken) er een geduchte concurrent bij: de neogotiek (Trier \& Weyres, 1980: 368). Vooral in de onmiddellijke nabijheid van de Dom verrezen veel neogotische woonhuizen. Maar deze mediaevalomanie, om zo te zeggen, in de Rijnlandse architectuur was slechts van korte duur. De neogotiek sloeg niet aan bij een breder publiek. Het eclecticisme, waarin werd gebruik gemaakt van onder meer elementen uit de renaissance en het rococo (ibid., p. 368), was voor de eliten misschien toch minder gewaagd.

Als het vermoeden terecht is dat Wickop"s artistieke voorkeur uitging naar de neogotiek, dan heeft hij in zijn latere leven zich toch weten aan te passen aan de eisen van de mode en de wensen van zijn opdrachtgevers, wat vaak op hetzelfde neerkwam. Men kan hem met recht een society architect $^{42}$ noemen. Hij was zeer in trek bij de Akense fabrikantenfamilies als de Von Nellessens en de Von Scheiblers, voor wie Wickop villa"s en buitens bouwde. Met deze industriëlen pleegde Regout in de jaren veertig overleg over de aanleg van de spoorlijn tussen Aken en Maastricht. Ook nadien heeft Regout relaties met hen onderhouden. Zeer waarschijnlijk is Regout via deze Akense entrepreneurs met Wickop in contact gekomen. Het ligt voor de hand te veronderstellen dat een of meerdere Akense in-

42 Hetzelfde geldt voor de Luikenaar Auguste Castermans aan wie Regout eveneens opdrachten heeft verstrekt (Archief Petrus Regout, Contractenboek 26, p. 214; zie ook: Castermans, 1865). 
dustrielen Wickop bij Regout heeft aanbevolen. Of dat Regout gevraagd heeft naar de naam van de architect van de fraaie aristocratische buitens waar hij te gast was.

Regout heeft een dubbele opdracht aan Wickop verstrekt: i) de bouw van een kapitaal woonhuis voor zijn oudste zoon en opvolger Petrus Alexander aan de brede en voornamelijk door Regout's toedoen steeds majestueuzer wordende Boschstraat en ii) de bouw van de Cité Ouvrière. ${ }^{43}$ Dit is een uiterst belangrijk gegeven voor de duiding van de Cité en daarmee van Regout's ambiguiteiten in deze. Alleen al het contrast tussen beide gebouwen is veelzeggend. ${ }^{44}$

De kadastrale kaarten laten zien dat het door Regout gekochte kavel een L-vorm had, met de voet van de L uitkomend op de St.- Anthoniusstraat, éen van de drie smalle straten die de arbeidersbuurt tussen Maas en Boschstraat dwars doorsneden. In deze 'dode hoek', die bij de koop was inbegrepen, heeft Regout de Cité Ouvrière laten bouwen (zie tekening 1).

Het lijdt geen twijfel dat Regout dit kavel heeft gekocht om er een luxueus woonhuis voor zijn zoon op te laten bouwen. Maar heeft hij het stuk mede gekocht omdat er een geschikte ruimte voor een woonkazerne bij was? Dat is uiterst onwaarschijnlijk. Het is veel waarschijnlijker dat Regout, geconfronteerd met een stuk grond waarmee niet veel kon worden gedaan - immers liggend aan de St.-Anthoniusstraat - maar ervoor heeft gekozen er een hoge arbeiderswoning neer te zetten. Wat had hij daar anders kunnen bouwen? De straat was te pover voor bewoning door een familielid, of om er een stuk tuin op te laten uitkomen. Voor industrieel gebruik was het evenmin geschikt, omdat het kavel te ver van de fabrieksterreinen lag. Als opslagplaats kwam het om logistieke redenen niet zo in aanmerking: Regout's opslagplaatsen lagen allemaal aan de havenkom het Bassin, waar de produkten gemakkelijk konden worden ingescheept.

43 De Cifé Owvrière is in 1938 gesloopt, maar het eerstgenoemde pand kan nog worden bezichtigd: het ligt op nr. 60 .

${ }^{44}$ Maar ook het contrast van de zo duidelijk aanwezige cité met de steegjes en sloppen - stad binnen de stad - waar een groot deel van het stedelijk proletariaat woonde, is opvallend. 
Tekening 1
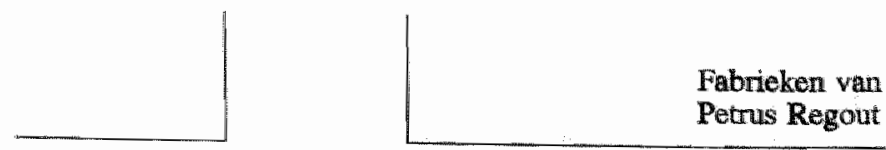

Boschistrant
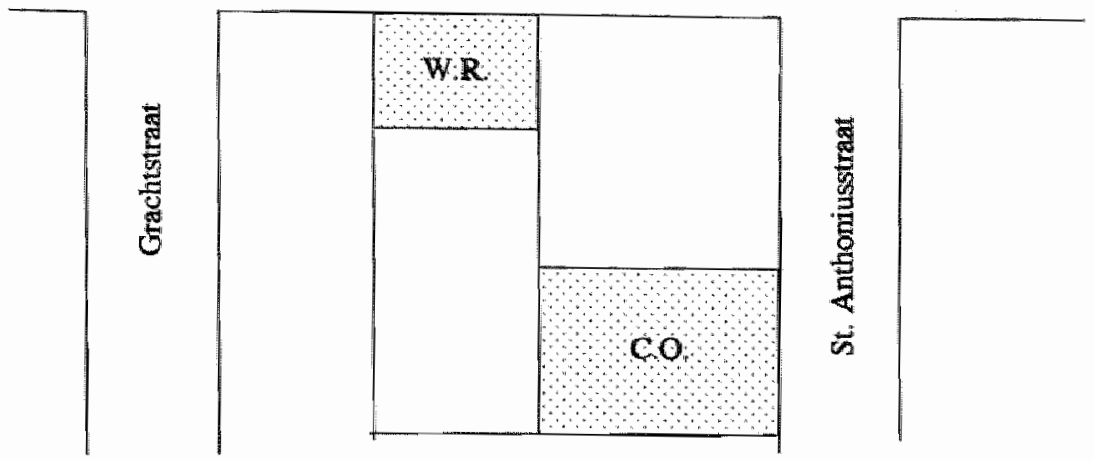

W.R = woonhuis Regout

C.O. = Cité Ovrière

Men mag redelijkerwijs aannemen dat de Cité Ouvrière geen doel op zich was. Maar toen het idee voor het gebouw eenmaal geboren was, wilde Regout er toch iets bijzonders van maken. Hij is er aitijd zeer trots op geweest. ${ }^{45}$ Dit moet in gedachten worden gehouden als de façade van het gebouw aan de orde komt.

Eén reden die Regout kan hebben gehad om de Cité iets extra's mee te geven, moet opnieuw in de ligging worden gezocht. De voet van het Lvormige kavel kwam weliswaar uit in een straat waar armen woonden, maar was toch dichtbij genoeg bij 'zijn' Boschstraat om een representatieve gevel te rechtvaardigen. Flad het terrein vijftig meter verderop in de straat gelegen, dan was er - maar dit is speculatief - geen Cite Ouvrière als deze verrezen. Eén van de mogelijkheden immers om zijn trots te laten blijken, was anderen het pand, dat wil zeggen de gevel, te tónen. Dat nu was mogelijk zonder dat Regout daarvoor met zijn bezoekers of anderen de St.-Anthoniusstraat zèlf hoefde te betreden. Vanaf de Boschstraat was de gevel goed te zien.

45 Daarvan mag reeds dit detail getuigen: op de sluitsteen van de Cité Ouvrière stond behalve het stichtingsjaar van het gebouw ook het familiewapen van de Regouts. 
Als mijn vermoeden juist is, kan men het zien als een gelukkig gevonden oplossing voor een probleem dat door de (industriele) burgerij in toenemende mate als pinlijk werd ervaren, naarmate deze meer statuskapitaal accumuleerde: het contact met alles wat met produktie en arbeid te maken had. Fabrieksterreinen, arbeidersbuurten en vooral arbeiders zelf werden meer en meer gemeden. Het kapitaal kon het niet zonder de arbeid stellen, maar wilde daar niet direct mee worden geconfronteerd.

In de beginjaren van de industrialisering werd dit contact niet zo problematisch gevonden. Op de prenten met nieuwe fabriekscomplexen kan men menig voornaam geklede dame en heer met parasol ontwaren. Dat is rond 1860 ondenkbaar geworden. In dat licht kan ook de verhuizing van Petrus Regout en zijn gezin naar kasteel Vaeshartelt in het landelijke Meerssen worden gezien. Dat lijkt mij niet uitsluitend aan toegenomen welvaart te moeten worden toegeschreven.

Nadat Regout hem opdracht tot het bouwen van een cité had gegeven, bezocht Wilhelm Wickop op Regout's kosten in Parijs en Luik een aantal bestaande cités (Archief Petrus Regout, Contractboek 26, p. 218). De vermelding van Luik is hier onverklaarbaar. Voor zover ik heb kunnen achterhalen zijn er in deze stad vóór 1865 geen cités ouvrières gebouwd (zie: Gobert, 1976: 212-15). Of werd in het Contractboek gedoeld op de twee cours van de Val St.-Lambert in Seraing? Mocht dat het geval zijn geweest, dan heeft Wickop zich niet door dit voorbeeld laten inspireren, of beter: kunnen laten inspireren, want hij 'had' maar 25 bij 35 bij 35 meter ruimte orn mee te woekeren.

Parijs ligt wèl voor de hand. Daar was in 1849 besloten tot de oprichting van cités ouvrières in de voorstad Neuilly met door particulieren bijelkaar te brengen geld. Louis Napoléon, juist aan de macht, gaf onder meer 50.000 francs, één tiende van het aanvankelijke kapitaal. De bewoners konden aandelen van 25 francs kopen. Later is deze Cité Napoléon afgebouwd met gelden uit een lening en met staatshulp. Het geheel is een mislukking geworden, voornamelijk, aldus A.M. Kuysten, door de tegenzin van de bewoners tegen kazernebouw (1923: 491).

In hoeverre Wickop zich door deze Parijse cités heeft laten inspireren is moeilijk te beoordelen. Cornips spreekt van "een slaafse navolging van het Parijse systeem", en hij voegt daaraan toe: "en daardoor niet in overeenstemming met de woonzeden in Limburg" (1952: 17). Volgens de kunsthistoricus Aart Mekking (1975) is het niet onmogelijk dat Wickop zich - althans voor wat betreft de bijzondere façade van de Cité Ouvrière - ook heeft laten inspireren door het bekende appartementsgebouw van Violletle-Duc in de Parijse Rue de Liège. Gelet op de bouwdatum van dit appartementsgebouw (1846-"48) is het zeker niet onmogelijk dat Wickop het tijdens zijn studiereis heeft gezien. Gelet op de reputatie van de bouwheer, diens op de Middeleeuwen geinspireerde stijl, de originaliteit van het ge- 
Afbeelding 1

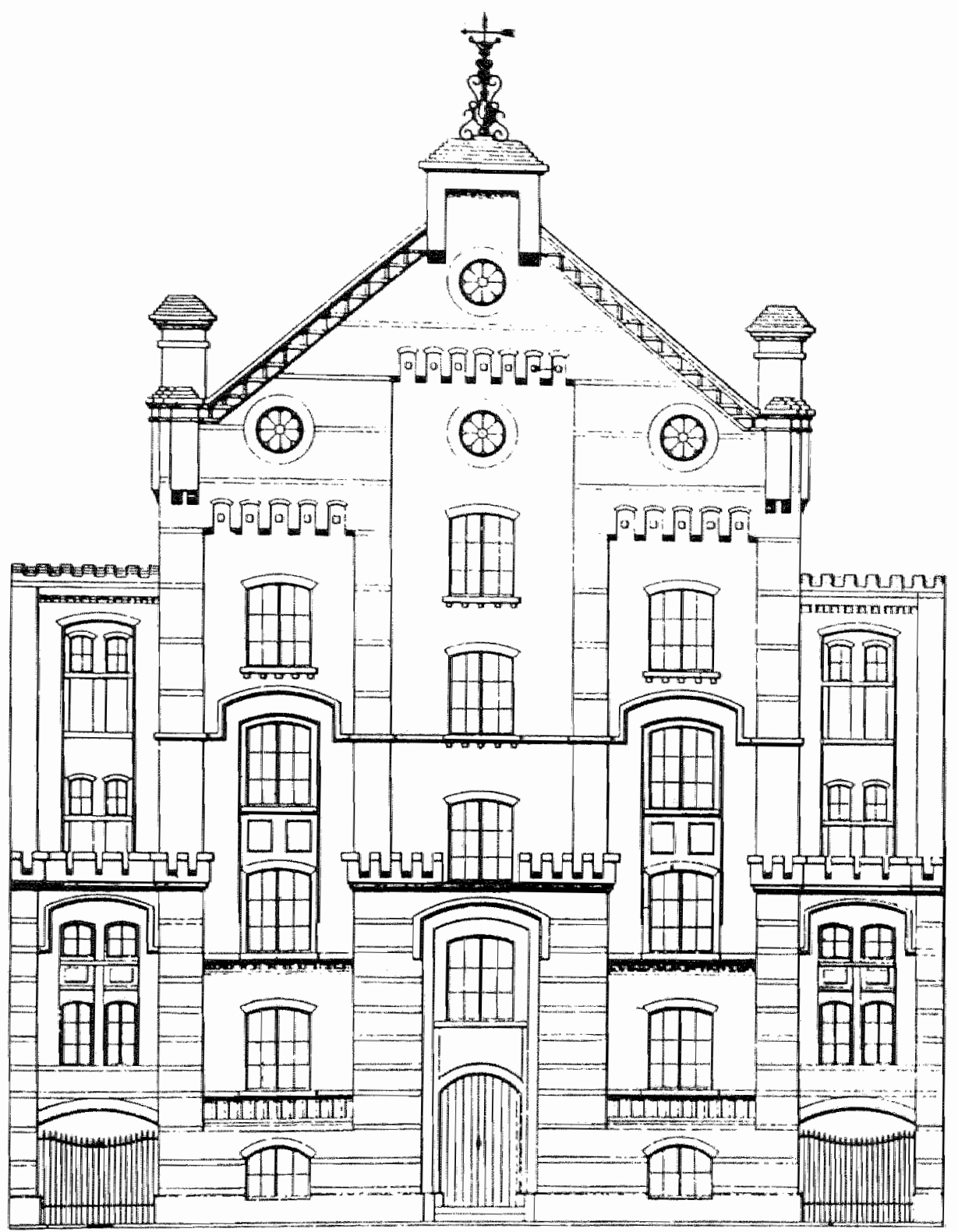

Cite Ouviere-fagade principate 1864. 
bouw en de bestemming (appartementen - de Maastrichtse Cité is welbeschouwd ook een appartementsgebouw) is het hoogst waarschijnlijk dat, mocht Wickop het hebben gezien, het gebouw hem zall hebben geboeid.

Kijken we eens nader naar de gevel van de 'Groete Bouw' (zie afb. 1) en de symbolische functie die deze misschien werd beoogd te hebben. Behalve aan Viollet-le-Duc's appartementsgebouw laat de forse omvang, de grote hoogte en het materiaalgebruik (voornamelijk bakstenen) van de Maastrichtse Cité Mekking denken aan een raadhuis of gildehuis uit een Hanzestad. Mekking spreekt van 'een rijzige en monumentale façade die ondanks de zeer levendige geleding, toch iets kazerne-achtigs over zich had' (ibid., p. 24). Ondanks het gebruik van aan de gotiek ontleende elementen, zoals fialen (siertorentjes die de topgevel bekronen), kantelen (waarvan een deel 'blind', dus verzonken in de gevel) en een centrale waterlijst die over de vensters heen loopt, is Wickop er in Mekking"s ogen niet in geslaagd de monotonie van een opeenstapeling van zeven verdiepingen vensters te doorbreken.

Wickop heeft ook geprobeerd die monotonie te breken door telkens twee vensters boven elkaar in spaarvelden te plaatsen. De aldus aan elkaar gekoppelde vensters worden nog eens extra verbonden door het gebruik van een lichtere kleur bakstenen. Wickop heeft deze koppeling ook toegepast bij de deur van het gebouw en de venster daarboven, in het middenrisaliet. Met de bekroning van kantelen krijgt deze partij de allure van een middeleeuwse stadspoort, aldus Mekking. De genoemde fialen en kantelen op verschillende hoogten versterken dit middeleeuwse voorkomen van de façade nog.

Met die kantelen lijkt iets bijzonders aan de hand. Doordat ze, voor een deel als 'blinde' kantelen, op vier verschillende hoogten zijn aangebracht, suggereren ze, als men op enige afstand, bijvoorbeeld op de hoek wan de Boschstraat, naar de façade kijkt, het aanzicht van een middeleeuwse stad in verkort perspectief. Zeer waarschijnlijk is deze suggestie met opzet gewekt. Mekking noemt de Cité Ouvrière van Petrus Regout/Wilhelm Wickop het enige voorbeeld in de negentiende eeuw van een weergave van een middeleeuws stadsgezicht. ${ }^{46}$

46 Mondelinge mededeling. Het zijn vooral de niet- of half-functionele kenmerken van artefacten die verwijzen naar gevoelens en waarden van opdrachtgevers en/of uitvoerders: stijlkenmerken, ordonnanties, decoraties, ornamenten, inscripties. Voor wie iets wil symboliseren, geven deze de beste kansen; wie niet dit oogmerk heeft, laat zich in deze kenmerken het meeste kennen, want ze zijn juist bedoeld on de aandacht van de buitenwereld te trekken. Bij architectonische artefacten vormt de façade het contact met de buitenwereld - het publiek krijgt doorgaans niets anders te zien. Vandaar dat voorgevels vaak worden aangegrepen om te woekeren met verfraaiende en symbolische attributen. 
De later als 'menschenpakhuis' verguisde Cité Ouvrière als beschermende veste? Is dat de gedachte achter de gevel? Mekking acht het zeker niet ondenkbaar dat het negentiende eeuwse ideaal-beeld van de christelijke werkgemeenschap van een middeleeuwse stad' in de gevelgeleding en -ornamentiek is uitgedrukt. Dit ideaalbeeld dat door

De negentiende eeuw is wel, voor wat betreft Westerse architectuur, de eeuw van de façade genoemd. Van 'verwijzende artefacten' vormen deze vaak rijke gevels een pregnant voorbeeld. Daardoor zijn deze arteracten nog niet gemakkelijk te interpreteren. Ook hier gelden de woorden van consultant Mario Viviani: I am convinced that the ability to theorize about the symbolic meaning of an artefact presupposes a wide and deep knowledge of the system in question' (1986: 25).

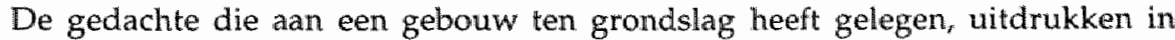
de gevel, was in de Nederlanden al in de zeventiende en achttiende eeuw in zwang gekomen. Men kan dit waarnemen bij openbare nutsinstellingen als weeshuizen en rasphuizen. Ook in de hofjesarchitectuur ziet men het: de poorten die naar de binnenterreinen leiden, zijn rijk voorzien van symboliek die verwijst naar de burgerzin en naastenliefde van de initiatiefnemers en de karaktervorming die het bij de inwoners effectueert. De regenten was er veel aan gelegen hun weldadigheid op de voorbijgangers over te brengen. Wat met de gevel van de Maastrichtse Cité is gedaan, kan men beschouwen als een naklank van deze opvattingen, meent Mekking. Uit de verbeelding van de Middeleeuwse veste zou kunnen spreken: de bouwer en eigenaar van dit gebouw wordt gedreven door burgerzin en naastenliefde.

Gevelsymboliek is ook te beschouwen als een commentaar op het gebouw waaraan een gezicht wordt gegeven. Zoals Clifford Geertz in zijn analyse van het Balinese hanengevecht heeft opgemerkt, leveren samenlevingen aan hun leden commentaar op zichzelf door middel van sommige van hun instituties: 'Like any art form - for that, finally, is what we are dealing with - the cockfight renders ordinary, everyday experience comprehensible by presenting it in terms of acts and objects which have had their practical consequences removed and been reduced (or, if you prefer, raised) to the level of sheer appearances, where their meaning can be more powerfuly articulated and more exactly perceived' (1973: 443). Deze commentariërende functie kan ook worden vervuld door mensen of met behulp van kunst, zoals (gevel)architectuur. Het commentaar-leveren kan niet de enige functie van een gevel zijn, want in tegenstelling tot hanengevechten, heeft een gebouw in de eerste plats een utilitaire functie. Maar een architectonisch artefact kan wèl deze additionele functie van versierend commentaar op zijn eigen bedoeling hebben, die dan letterlijk ertegenaan is geplakt. In het geval van Regout's Cité zal de ambigue relatie tussen de functionele en symbolische functie door velen als een veelzeggende incongruentie worden gezien. 
Mekking wordt aangeduid past goed in wat hier als paternalistisch is gedefinieerd. ${ }^{47}$

Aangenomen dat deze suggestie inderdaad met opzet is gewekt, dan is de vraag: wiens opzet? Wiens paternalistisch-middeleeuwse idealen worden in deze gevelsymboliek gerepresenteerd? Die van Regout of die van Wickop? Die van de sociale groep waartoe Regout hoorde of wilde behoren, of die van de artistieke traditie waarin Wickop zich voelde staan, of waartegen hij zich wilde afzetten?

Het idee van de gevel dient zonder veel twijfel volledig op rekening van de architect te worden geschreven. Maar dat is geen afdoend antwoord. Dat het idee van Wickop moet zijn geweest, mag duidelijk zijn geworden

47 In deze paragraaf ligt de nadruk op de gevel. Bij grotere projekten bestaat ook de mogelijkheid de gehele uitleg van de gebouwen en de architectonische differentiatie daarin ter symbolisering aan te grijpen. Smets: Door de woongemeenschap rondom de fabriek als centrum uit te bouwen, wordt duidelijk gemaakt dat deze gemeenschap alleen bij de gratie van de fabriek kan bestaan. Het onderscheid tussen de monumentale fabrieksgebouwen en de simpele worvingarchitectuur is (..) een uitdrukking van de machtspositie van diegene die de monumentale fabriek bezit, tegenover diegenen die in de simpele woningen daaromheen wonen en die in die fabriek mogen komen werken' (1977: 13-4). De hiërarchische verhoudingen birnen de fabriek liggen ten grondslag aan de verschilten in de bouw voor respectievelijk opzichters, geschoolde en ongeschoolde arbeiders. "De hiërarchische positie die een bewoner in de fabriek bekleedt, wordt uit de grootte en de architektuur van zijn woning afleesbaar. De machtsverhoudingen die binnen de fabriek bestaan, worden in het woonmilieu nog eens verstevigd' (ibid., p. 14).

Smets merkt verder op dat met het bouwen van cités rondom de fabriek ook wel een verdeel-en-heers-politiek werd toegepast. Door uitsluitend de meest produktieve en beschaafde arbeiders aldus te huisvesten en aan zich te binden, werden ze min of meer van de andere arbeiders gescheiden, zodat in geval van staking of andere onlusten de soliclariteit onder de arbeiders gemakkelijker was te breken. Men kan dat zelfs heel letterlijk opvatten: door de arbeiderswoningen rondom de fabriek (en de direktiewoning(en)) te bouwen, konden deze als buffer dienen bij calamiteiten. Maar hiermee hebben we het veld van de symboliek verlaten.

Het onderscheid tussen monumentale fabrieksgebouwen en simpele arbeiderswoningen en de symboliek van hierarchische verschillen die daaruit spreekt, herkent men ook in het filantropisch geachte initiatief van de cité van Le GrandHornu. De hiërarchische verhoudingen binnen deze mijn vinden ook - duidelijker dan op menige andere plaats zelfs - in Le Grand-Hornu weerspiegeling in de architektuur van het hele complex. In Le Grand-Hornu bestonden verschillende woningtypen voor gewone arbeidskrachten en meestergasten. En woor de direkteurs en administrateurs van het bedrijf was zelfs 'een soort kasteel' voorzien in de Rue Royale. 
wit zijn korte levensbeschrijwing, met name uit zijn medewerkerschap bij Zwirner, wiens Dom-projekt een neo-gotische mode had teweeggebracht, waarin paternalistische thema's een plaats hadden. Dat ook Wickop door dit nieuwe artistieke paradigma was gegrepen, getuigt onder andere zijn illustreerwerk voor uitgaven over middeleeuwse kunst.

Het lijkt goed mogelijk dat Wickop van Regout voor de Cité Ouvrière een 'vrije' opdracht heeft gekregen, om naar eigen goeddunken iets met de façade te doen, welke kans hij dan heeft aangegrepen on zijn liefde voor de neo-gotiek bot te vieren. Het kan ook zijn dat Regout hem een opdracht heeft gegeven met als enige voorwaarde dat uit het façade-ontwerp zijn goedertierenheid jegens zijn arbeiders moest blijken. Ook dan heeft Wickop de vrijheid gehad om zijn voorkeur te volgen, want, nogmaals, middeleeuwse motieven lenen zich goed voor de uitdrukking van dergelijke gevoelens.

Al was Wickop betrekkelijk vrij in de invulling van zijn opdracht, we mogen aannemen dat Regout wèl verwachtte dat het ontwerp bijzonder zou worden. Wickop mocht immers van hem naar Parijs om zich wan de cités daar op de hoogte te stellen. Regout - die, moet men bedenken, toen al 62 was en gearriveerd - was bereid aanzienlijke extra kosten te maken. Dat is een vrij hard bewijs dat hem er toch wat aan gelegen was om er iets fraais van te laten maken. Het deed waarschijnlijk niet zoveel ertoe wàt precies - dat kwam wel in orde met deze architect, zal de redenering zijn geweest - , als het maar iets was met een of andere symboliek waaruit de barmhartigheid sprak die ook tot dit initiatief had geleid. Waarbij dan tevens kon worden opgemerkt: net zoals dat initiatief in Parijs, waaraan doom" keizer Louis Napoléon Bonaparte was bijgedragen. ${ }^{48}$

Als het idee van Wickop zelf is, waarvan ik uitga, dian neemt dat natuurlijk niet weg dat Regout het ontwerp minstens heeft moeten goedkeuren, mogelijkerwijs niet na voorstellen of eisen tot verandering naar voren te hebben gebracht. In de eeuw warin de façade van een gebouw zulk een belangrijke rol speelt, zal er zeker uitvoerig over gesproken zijn

48 Bij eerdere huisvestingsinitiatieven voor arbeiders heef Regout geen gevelverfraaing toegepast. Is het te gewaagd om te veronderstellen dat de Cité in de Sint-Anthoniusstrat een witing is var trots op wat hij inmiddels had bereikt? In dat opzicht zou dit woningbouwinitialtief een omslagpunt kunnen betekenen. Zoals de periode na de crisisjaren van 1848-1851 voor Regout een materieel omslagpunt waren, zo waren de jaren zestig voor hem in menig opzicht cultureel omslagpunt. Vanaf die tijd vond hij wellicht dat er bij zijn nieuwe positie als succesvol fabrikant ook een adequate symbolisering van dat succes hoorde, die bij voorkeur tevens een legitimering van zijn verworven vaderlijke positie tegenover de stedelijke arbeidersklasse moest zijn. 
fussen architect en opdrachtgever. Ook om een andere reden moet er over het ontwerp zijn gesproken. Regout had Wickop immers op zijn, Regout's, kosten naar Parijs laten gaan. Wickop moet die studiereis hebben verantwoord; hij moet hebben laten zien dat de gemaakte kosten niet vergeefs waren geweest - voor hem een reden te meer om met een bijzondere gevelgeleding te komen, als 'extra' bovenop het eigenlijke ontwerp voor het gebouw.

Als Regout het ontwerp zoals het is uitgevoerd, heeft goedgekeurd, dan weerspiegelt het ook iets van zijn gevoelens en gedachten ter zake. Want ook het feit dat hij niet meer heeft gedaan dan accoord gaan met dit voorstel 'zegt' iets: dat het idee achter de gevelgeleding op zijn minst niet in strijd was met wat hij vond.

De volgende vraag luidt dan: waarom heeft Regout dit ontwerp goedgekeurd? Er ontstaat bij zo een interactie, waarin een opdrachtgever samen met de uitvoerder diens ontwerp doorneemt, een confrontatie van twee verschillende 'werelden' die tot een 'fit' moet leiden. Daar wordt althans naar gezocht, want de opdrachtgever heeft er, gelet op de geïnvesteerde kosten, belang bij een ontwerp te aanvaarden. De principaal zal, geconfronteerd met een ontwerp, de neiging vertonen dit te willen inpassen in zijn culturele patroon, bij wat hij mooi, goed of rechtvaardig vindt. ${ }^{49}$ Zo probeert men voortdurend nieuwe gebeurtenissen in overeenstemming te brengen met de waarden die men reeds koesterde - zeker indien men er een materieel belang bij heeft. Dit sluit niet uit dat nieuwe gebeurtenissen iemands waarden(systeem) kunnen veranderen, ook al zijn waarden moeilijker te veranderen dan de meer oppervlakkige praktijken (Hofstede, 1991: 8). Een andere mogelijkheid is dat bepaalde gebeurtenissen juist worden begroet omdat ze een veranderend waardensysteem ondersteunen. Het ontwerp van de Cité Ouvrière zou wel eens zo een 'welkome gebeurtenis' kunnen zijn voor Regout: een in zijn ogen geslaagde symbolisering van de genoemde trots en paternalistische gevoelens die hij meer en meer bij zichzelf gewaar werd, naar mate hij als fabrikant meer succes boekte en aan macht won.

Voor de confrontatie van het samen doornemen van het ontwerp kan ik vier scenario's bedenken. Drie zijn al behandeld:

i) de principaal heeft een nauwomschreven opdracht gegeven en controleert of de agent zich eraan heeft gehouden;

ii) de principaal wordt geconfronteerd met een nieuw idee en tracht dit in te passen in zijn bestaande waardensysteem;

${ }^{49}$ Zo zou men rationaliseren kunnen definiëren als: zoeken naar het antwoord "het past". 
iii) de principaal begroet het nieuwe idee als een ondersteuning van zijn veranderende waardensysteem.

Het vierde scenario is:

iv) de principaal begrijpt het nieuwe idee niet, maar denkt dat het wel goed zal zijn, want de agent aan wie hij de opdracht heeft verstrekt heeft een goede naam.

Wickop was geliefd bij de Akense industriëlen - families voor wie Regout een zeker ontzag koesterde, omdat zij iets hadden bereikt dat hem nog niet zo was gelukt: status en aanzien, niet alleen op stedelijk, maar ook op national niveau, wat ook uitdrukking vond in het verlenen van adellijke titels door de Pruisische overheid. Als het idee achter de gevelgeleding inderdaad geen betekenis woor Regout had, kan dat haast niets anders betekenen dan dat Wickop niét erbij heeft gezegd dat de symboliek verwijst naar de gedlachte van beschermende veste", want als er iéts is dat Petrus Regout graag wilde zijn ten opzichte van 'zijn' arbeiders, dan is het: beschermheer. Het is uitgesloten dat het idee van veste, mits goed uitgelegd, hem niet zou hebben aangesproken. Maar als het niet dusdanig is toegelicht door de uitvoerder, heeft deze het óok niet zo gezien. Dat wil zeggen dat hij de "ideologie' achter de bouwstijl waartoe hij zich aangetrokken voelde, niet begrepen heeft. Dat is onwaarschijnlijk.

Maar àls Regout nu wel was verteld dat de gevel symbolisch was voor zijn houding tegenover zijn arbeiders en hij hàd het begrepen, zou hij er dan geen gewag van hebben gemaakt in publicitaire publikaties als het Album dédié à mes enfants et mes amis? Daarin staat de Cité Ouvrière uitgebreid afgebeeld als filantropisch initiatief, met bijvoorbeeld een minitieuze afbeelding van de aangebrachte riolering. Maar over het gevelontwerp geen woord. Het is niet zo dat Regout vond dat het er te dik bovenop zou liggen als hijzelf er melding van maakte. Hij was niet de man die vond dat iets er te dik bovenop lag. Het is eerder zo dat zo een idee zich niet laat zeggen. Althans niet door Petrus Regout. Dat taalspel beheerste hij niet. Hij vond dat het gevelidee bij zijn opvattingen paste, nadat het hem was uitgelegd, maar verder kon hij er niet veel mee. Ongetwijfeld herkende hij niet meteen de symboliek - vrijwel niemand heeft het na hem herkend - maar toen hij het wèl zag, was hij vervolgens niet in staat zèlf de symboliek voor anderen te verduidelijken. Dit was geen tekortkoming. Regout was als participant niet bij machte die afstand te nemen om er op die manier over naar buiten te treden. Hij begreep het wel, neem ik aan, maar kon zich naderhand niet de luxe van de interpretatie ten behoeve van anderen permitteren. Daarvoor zat hij er te dicht bovenop. Na de Cité heeft Regout niets meer aan symbolische versiering van arbeidershuisvesting laten doen. 

'pauperisme-vraagstuk'

[..] de bourgeoisie heeft me altijd gefascineerd, in haar fantasma, het geobsedeerd zijn door de adel. De omstandigheid dat de bourgeoisie zich nooit op symbolische wijze heeft kunnen legitimeren - ze had alle macht, economisch zowel als politiek, maar de symbolische macht miste ze. Dat gebrek, dat koortsachtige, zinloze zoeken, dat boeit me.'

Perrot, Philippe (Vrij Nederland, Boekenbijlage, nr. 39, 26-9-1987, p. 1).

In deze paragraaf wordt een voorbeeld beschreven van legitimering van interne arbeidsverhoudingen via het woord. Het schrijven (of laten schrijven) van boeken, brochures, artikelen en prospectussen is een beproefde manier om een bepaald publiek op de hoogte te stellen omtrent de eigen gevoelens, gedachten en verrichte handelingen en daden die legitimerende openbaring en commentaar behoeven. Vooral als opvattingen en waarden in de relevante contexten aan drastische verschuivingen onderhevig zijn, kunnen publicaties een belangrijke legitimerende functie vervullen.

Petrus Regout heelt, als gezegd, veel gepubliceerd ${ }^{50}$ : een zeventig brochures, adressen, open brieven, rekesten en replieken over zeer uiteenlopende onderwerpen. Meest lokale en handelspolitieke kwesties, maar hij heeft zich ook in publieke discussies gewaagd, zoals met de

50 Let wel: 'gepubliceerd", niet "geschreven". Het is niet duidelijk in hoeverre de formuleringen zijn toe te schrijven aan Regout of zijn medewerkers. Waarschijnlijk komen de feiten en argumenten grotendeels van Regout en heeft zijn secretaris enkele esthetische uitweidingen bedacht. Men kan in Pauperisme en industric een opmerkelijk contrast constateren tussen uiterst gedetailleerde passages van doorgaans beschuldigende of eisende aard en lyrische excursies die ontwikkeling en goede smakk moeten suggereren (zoals: "lagchende beemden', p. 15).

Misschien heeft Jos. Russel aan deze brochure bijgedragen. Russel werd door Regout 'mon sécretaire intime' genoemd en 'une personne attachée à ma maison'. Hij was ook de redacteur van de genoemde lokale krant L'ami du Limbourg, Regout's wapen in de strijd tegen de liberale stedelijke elite (Maenen, 1959: 106-7) en schreef Regout-gezinde brochures (Russel, 1866), alsmede een korte levensbeschrijving van Petrus Regout (Russel, 1869).

Opnieuw kan men hier spreken van een principaal-agentsituatie, zij het dat bij deze vorm van produktie het voor de principaal eenvoudiger is om zijn agent te monitoren. Van alle symbolische kunsten en kundes is die van het schrijven de minst esoterische. 
brochure Pauperisme en industrie uit 1858, een Proeve ter beantwoording wan de vraag: Wat is er te doen tot verbetering van de werking der Bedelaarskoloniën? Met deze bedelaarskoloniën worden de bekende veenkolonièn bedoeld, die door graaf Johannes van den Bosch, stichter wan de Maatschappij van Weldadigheid en later Minister van Koloniën, waren opgericht (voor een biografie zie: Westendorp Boerma, $1927^{51}$ y.

De gedachte om de Maatschappij van Weldadigheid op te richten, sproot voort uit een al wat ouder gevoel onder verschillende elites. In de achttiende eeuw kon men vaker de verbazing horen uitspreken dat er zoveel armlastigen waren, vooral in de steden, terwijl er bijvoorbeeld nog zoveel woeste grond kon worden ontgind. Men hoefde deze armen maar op de heidegronden te werk te stellen om er zelfstandige boeren van te maken, waarmee dan tevens ook de steden voor een belangrijk deel van dit grote probleem zouden worden verlost. Ontginning van woeste gronden als middel om permanente werkeloosheid in de steden tegen te gaan en als middel om zelfstandige boeren te maken van onzelfstandige armen.

De belangstelling voor de Maatschappij was meteen overweldigend. Binnen enkele maanden waren er al bijna 15.000 leden en kort daarna werden de eerste kolonisten in Frederiksoord ontvangen. Daarop volgden de andere twee 'vrije kolonien' op de grens tussen Overijssel, Drenthe en Friesland: Willemsoord en Wilhelminaoord. In 1824 waren er al 7 kolonies met 430 hoeven. Op de ontgonnen grond werden bedrijfjes gesticht van twee ha, waarop twee koeien graasden. De belangrijkste produkten die op de lapjes grond werden verbouwd, waren aardappelen en rogge.

Maar de verwachting - "eene algemene kolonisatie op alle woestliggende gronden' - kwam niet uit. In de jaren twintig en dertig kreeg de Maatschappij te kampen met steeds toenemende tekorten, vooral ook, zo werd links en rechts geoordeeld, doordat veel ongeschikte arbeidskrachten te werk werden gesteld. De problemen verergerden toen in de jaren weertig de aardappelziekte uitbrak en het aantal armlastigen op het platteland drastisch toenam.

In de tijd dat Regout zijn brochure schreef, had de Maatschappij van Weldadigheid een schuld van enige miljoenen en stond op het punt failliet te wordlen verklaard. Verder had de publieke opinie zich tegen de Maatschappij gekeerd; er had zich, in Regout's woorden, 'een' geest van onwil en ontevredenheid geopenbaard, die op slooping van die eenmaal zoo gevierde Maatschappij aandringt".

Waarom mislukten deze landbouwkolonies? Er waren te veel armlastigen om de steden te ontlasten en zij die in de kolonies te werk werden

51 Ik heb voornamelijk gebruik gemaakt van het artikel "Verheffing op de woeste grond" van Willem van der Ham (NRC-Handelsblad, 13-2-1988, Zaterdag Bijvoegsel, p. 3). 
gesteld, verdienden te weinig om het zonder ondersteuning van armenfondsen te redden. Daarbij werden er door de Maatschappij fouten gemaakt: de organisatie was ondeugdelijk, de opzet was te groot, er was een gebrek aan kennis van ontginningstechnieken. Bovendien werd te weinig ingezien dat het stadsproletariaat niet gemakkelijk tot boer of landarbeider kon worden omgevormd, laat staan tot een goede.

Regout begint zijn brochure met het constateren van een paradox. We leven in een' tijd, waarin zich het verschijnsel voordoet, dat, naarmate beschaving en rijkdom in het algemeen wooruitgaan, de armoede aan den anderen kant toeneemt." Hoe meer de beschaving toeneemt, ofwel: hoe meer de kracht van het kapitaal zich doet gevoelen, redeneert Regout, hoe moeilijker het voor de minder bevoorrechten wordt om zelf het nodige te verdienen. Dit verschijnsel treedt volgens Regout in hoge mate op '[i]n een* tijd, waarin uitvindingsgeest zulk eene ontzettende vlugt heeft genomen en handenarbeid wordt vervangen door zoovele andere krachten.' Want in zo een tijd neemt het produktief vermogen toe, alsook 'de algemene rijkdom', maar tegelijkertijd kunnen velen niet meer op hun oude wijze in hun bestaan voorzien, terwijl ze toch ook 'grotere behoeften gevoelen en bevredigen willen'. Voor deze mensen moet een uitweg worden gezocht; dat is 'het groote maatschappelijke raadsel van onze dagen.'

Niet de uitweg van degenen die de woorden pauperisme, democratie, socialisme en communisme in de mond nemen, uiteraard, en die het recht op eigendom in twijfel trekken. Dat zijn de mensen die 'de eeuwige wijze wetten der Voorzienigheid miskennende, den pligt tot den arbeid verwarren met een regt op arbeid, en die de grondslagen van het maatschappelijk gebouw liever willen omverwerpen, dan afleiding en verbetering zoeken voor een' tijdelijk ziekelijken toestand.'

Ook in Nederland, dat gelukkig minder te kampen heeft gehad met 'de verderfelijke zucht om eene maatschappelijke omwenteling tot stand te brengen" is het probleem van het pauperisme een belangrijk vraagstuk, schrijft Regout. Eén-zesde van de bewoners van Nederland kan niet zonder ondersteuning leven; voeg daarbij de genoemde toenemende behoeften, en de bevolkingsgroei, dan moet dit alles grote zorgen baren.

Petrus Regout koestert niet de illusie dat zijn denkbeelden omtrent het armenvraagstuk algemeen zullen worden gedeeld, maar hij schrijft ze toch op 'omdat wrijving van denkbeelden licht kan veroorzaken'. Ook zegt Regout niet de illusie te koesteren 'een panacée tegen het pauperisme in deze weinige bladzijden te ontwikkelen.' Hij wil slechts enige gedachten aangaande een veelbesproken onderwerp onder de aandacht brengen die misschien voor toepassing vatbaar kunnen worden bevonden.

Regout noemt graaf Van den Bosch 'een man van onmiskenbaar genie', die begreep dat arbeid voor den mensch eene voorwaarde van bestaan is, 
zoowel een waarborg voor zedelijke ontwikkeling als voor stoffelijk welzijn. Hij begreep dat orde, rust en tevredenheid daar heersen, waar arbeid goed beloond wordt."

De schuld van de neergang van de Maatschappij van Weldadigheid legt Regout bij de staat. Was de Maatschappij 'aanvankelijk bestemd om aan gezonde en krachtige menschen land aan te wijzen', de staat droeg haar na verloop van tijd op 'de verzorging van hen, die wegens bedelarij veroordeeld waren en dreigden om na afloop van den straftijd weder tot het vorig bedrijf te zullen terugkeeren, omdat zij of de middelen niet konden vinden om in hum bestaan te voorzien, of niet gewoon waren om door geregelden arbeid het levensonderhoud te verdienen.' Dat was niet alleen 'het ongelukkig gedeelte van onze bevolking', mensen die door honger en gebrek gedreven waren gaan bedelen, maar ook de luiaard ('die, ofschoon gezond en sterk, liever zwervend en bedelend het land afliep en misbruik maakte van de algemeene liefdadigheid'), het 'schuim der groote steden', dat, in armoe en zedeloosheid opgebracht, de kracht niet heeft om in eigen onderhoud te voorzien, en, '[w] at meer is', invaliden.

Voor deze onvrijwillig tewerkgestelden werden de kolonie Veenhuizen, bestaande uit drie gestichten, de kolonie Ommerschans, waar zowel een gesticht als een strafkolonie toe behoorde, en de kolonie Wateren, mett een opvoedingsgesticht, in het leven geroepen. De oorspronkelijke opzet - in eigen behoeften voorzien door landbouw - kon met deze onvrijwillig tewerkgestelden niet worden verwezenlijkt. Gevolg: de Staat, en ook de gemeenten, moesten erop bij leggen. Een andere maatregel die de Staat in het bijzonder voor 'invaliden' trof, was de Maatschappij de levering van 'zeker fabrikaat' op te dragen: voomamelijk geweven en gesponnen goederen, zoals koffiezakken en imitatiekatoen voor het leger in de koloniën, maar ook ter voorziening van de eigen behoeften.

Regout zelf spreekt van 'scholen van misdaad'. Zijn conclusie: 'De toestand op dit oogenblik vordert dringende hervorming [... $]^{\prime}$. Tot die conclusie was de Staat ook al gekomen. Hij stelde voor de landbouwkolonies en de bedelaarsgestichten te scheiden. Met deze maatregel zou aan de Maatschappij van Weldadigheid haar oorspronkelijk doel worden teruggegeven: de landbouwkolonies zouden weer geheel onder beheer van de Maatschappij komen en de gestichten zouden geheel onder staatsbeheer gaan vallen.

Regout zag mogelijkheden dat met deze scheiding de Maatschappij van Weldadigheid weer kon opbloeien. 'Maar' vroeg hij zich af, 'zal men nu de bedelaarskoloniën op denzelfden voet laten bestaan?' Of zal de Staat de bevolking van de gestichten verspreiden over de gemeenten, zoals wordt geopperd? Geldt dat dan ook voor de bedelaars die er nog bijkomen, die enige tijd na hun veroordeling de gevangenis verlaten en in hun oude fout vervallen? Maar de vraag die Regout nog het meest indringend stelt: 
Bestaat er ook middel om de bedelaarsbevolking in Nederland te veranderen in eene productieve kracht voor ons land en om daardoor het bestaande pauperisme op eene krachtige wijze tegen te gaan? Zijn antwoord is positief. De oplossing: de bedelaars moeten in dienst worden genomen bij fabrikanten, waarbij deze laatsten van de overheid zo veel mogelijk medewerking en ondersteuning dienen te krijgen. Een citaat: 'Het bestuur (van dergelijke fabriekskoloniën, avi) moet gevoerd worden door van Staatswege bezoldigde ambtenaren. De Burgemeester, zijn Secretaris en de Rijksveldwachters moeten door het Rijk bezoldigd en verder alle zoodanige subsidiën gedurende den tijd van 20 jaren verleend worden, die aan volstrekt onvermogende gemeenten worden verstrekt. Burgemeester en Secretaris moeten regtsgeleerden zijn en bij de keuze daarvan gelet worden op zoodanige personen, die woonachtig zijn in streken, waar industrie bestaat, of die wezenlijk met de belangen van de nijverheid bekend zijn. De geheele politie en het onderwijs komen alzoo ook ten laste van het Rijk, terwijl de nu in de koloniën aanwezige geestelijken eene bezoldiging uit 's Rijks schatkist moeten blijven trekken. Ter verzekering van de orde moet, volgens het Pruissische stelsel ${ }^{52}$, eene compagnie dragonders, als maréchaussée, in die streek garnizoen houden, waarvoor de kazerne in de nabijheid van de Burgemeesters-woning moest gebouwd zijn. Eene cellulaire strafgevangenis moet evenzeer in de nabijheid van de Burgemeesters-woning opgerigt worden. De mest, die in de kazerne opgezameld wordt, zou kunnen strekken tot het vruchtbaar maken van de plekjes grond rondom de woningen, die tot tuinen worden aangelegd, en er moet zorg worden gedragen, dat van deze kostbare specie eene gelijkmatige verdeeling plaats hebben. Voor behoorlijke geneeskundige hulp moet eenige voorziening worden getroffen. Een Kantonregter moet ook in de koloniën bevestigd zijn.'

Ondanks de details - zoals de aanbeveling om paardemest aan te wenden bij het vruchtbaar maken van de tuintjes - is het moeilijk denkbaar dat Regout serieus heeft gemeend dat zijn plan enige kans van slagen had. Als men zijn voorstel afzet tegen ontwikkeling en status van de nationale industrie, kan men niet anders concluderen dan dat het utopisch gehalte te hoog is.

Mijn inschatting is dat Regout met deze brochure een verzwegen bedoeling had, die zich slechts op indirekte wijze liet zeggen, wilde deze

52 Het Pruisisch leger stond bekend om zijn strenge discipline op een rationele grondslag. Paraatheid en plichtsgevoel werden op een methodische wijze aangeleerd. Deze systematische en efficiënte strengheid tolereerde weinig twijfel en onzekerheid; vandaar het motto: 'Nicht raisonnieren!' Overigens was het Pruisische leger voor Maastricht geen abstractie, maar een nabije realiteit, want Aken was sinds 1815 Pruisisch gebied. 
niet een averechts effect sorteren. Ik denk dat Regout hier via een omweg zijn eigen bezigheden als fabrikant wilde legitimeren. Door zijn industriele utopie te schetsen, probeerde hij de industriële werkelijkheid die hij had geschapen - en die voor velen nog steeds een anomalie was - te rechtvaardigen. Het paternalistische gehalte van deze werkelijkheid was vele malen geringer dan dat van zijn geschilderde utopie - en daarmee, veronderstel ik, voor anderen iets gemakkelijker om te accepteren. ${ }^{53}$ Had hij zich 'rechtstreeks' gelegitimeerd dan was juist het afwijkende ten opzichte van de gewone situatie opgevallen.

Wat verder in deze brochure treft is dat Regout bepleit dat de overheid op allerlei manieren faciliterend, beperkend en corrigerend optreedt opdat de industrie haar vrijheid van handelen gewaarborgd ziet. Tarieven dienen te worden ingesteld, bedelaars ter beschikking gesteld, dragonders geleverd, met als belangrijkste doel als kaders te fungeren ter garandering van de handelingsvrijheid van de fabrikanten. (Kaders ter garandering van de vrijheid: vandaar de militaire metaforen.) Opnieuw herkent men hier een tweeslachtigheid - noem het: dubbele moraal - tussen de waarden van markten en hiërarchieën.

Bij dit alles moeten de beoogde lezers voortdurend in overweging worden gehouden. Afhankelijk van de geadresseerde(n) veranderen geuite denkbeelden omtrent, bijvoorbeeld, arbeid en arbeiders. Het volgende citaat uit een brief van 19 april 1864 aan de gemeenteraad van Maastricht zou niet goed denkbaar zijn in een bijdrage van Regout aan het pauperisme-debat: Intusschen leert de ondervinding mij dagelijks, dat wat den aanbouw van woningen betreft voor een getal van 2000 werklieden, nog geenszins genoeg is gedaan. De publieke opinie is het daaromtrent volkomen met mij eens; er moet nog meer voor de hoogst verdienstelijke arbeidende klasse in deze stad worden gedaan, die zich uitmuntend gedragen."

Verderop in het adres spreekt hij van "het eerlijke nijvere deel der bevolking' - in tegenstelling, waarschijnlijk, tot het oneerlijke, onnijvere deel van de bevolking: het lompenproletariaat dat van de bedeling leeft of van oneerzame werkzaamheden. De aard van zijn wensen - woningen te bouwen voor zijn arbeiders en zijn opponenten in het college van B\&W tegen te streven - is hier sterker dan zijn bevoogdende instelling. Vandaar dat hij hier de (zijn) arbeiders méér kwaliteiten toeschrijft - uitmuntendheid, eerlijkheid, nijverheid - dan hij werkelijk geloofde.

53 Wat hier misschien ook meespeelt is Regout's ongekende dadendrang die, in een tijdperk dat daardoor niet bepaald werd gekenmerkt, waarschijnlijk eveneens rechtvaardiging behoefde. Uit dit motief zou ook iets van de gedetailleerdheid en extremiteit van zijn plannen kunnen worden verklaard. 
Regout's publicaties over het pauperismevraagstuk zijn een vorm van impression management: legitimering van bestaande praktijken door idealisering van (nog) niet bestaande praktijken. 


\title{
HOOFDSTUK 6
}

\author{
TOT SLOT
}

De probleemstelling van deze studie luidde: in hoeverre waren patronen van werven, behoudem en beheersen van arbeid door industriële entrepreneurs in de begintijd van de Westeuropese Industriële Revolutie - in het bijzonder Petrus Regout - een resultante van i) de markt- en omgevingsfactoren (en de eigen fysieke beperkingen) en ii) hun persoonlijke stijl van denken, voelen en handelen? Het antwoord luidt: het element 'stijl van de fabrikant' is een essentiële factor bij genoemde patronen van management - net zoals het dat is bij (sociale en economische) andere beslissingennemers, in andere tijden. In het geval van de Maastrichtse glas-, kristal- en aardewerkfabrikant Petrus Regout was deze stijl overwegend paternalistisch.

Regout's stijl is niet volledig te begrijpen uit de nationale -, of regionale -, of stedelijke - of familie $\mathrm{e}^{1}$ cultuur waarin hij opgroeide, maar is er wèl opvallend congruent mee. Dat Petrus Regout is geboren en getogen in de Maastrichtse middenstand, met haar alzijdige oriëntatie op het Zuiden, verklaart veel van zijn stijl, die hij ontwikkelde in het werven, behouden en beheersen van arbeid in zijn moderne fabrieken. Dat Maastricht in de tweede helft van de negentiende eeuw haar oriëntatie in noordwaartse richting omboog, en meer en meer in de Nederlandse instituties en cultuur werd geintegreerd, verklaart veel van de - doorgaans negatieve reacties op Regout's stijl en meer nog op die van zijn zonen.

Omdat Petrus Regout, die zich toch met een zo moderne aktiviteit als de grootschalige industrie bezighield, onbuigzaam bleef vasthouden aan waarden en praktijken uit een andere tijd en een ander land, groeide de weerstand in stad en land. De zonen Regout, die de leiding over de verschillende bedrijfsaktiviteiten in de jaren zeventig overnamen, hadden echter geen paternalistische, maar een liberale stijl ontwikkeld - nog wel de hardvochtige, cynische variant ervan. Misschien kan het aannemelijk worden gemaakt dat dit ten dele een reactie op genoemde weerstanden

Overigens kan de familiemetafoor woor economische bindingen een aanvulling zijn op het gangbare idioom van het liberale en socialistische perspectief waarin eigenbelang centraal staat. De familiemetafoor vindt onder andere uitdrukking in het begrip paternalisme. 
was. De beruchte antwoorden van de zonen Regout gegeven tijdens de Parlementaire Enquête van 1887 - Alle menschen zijn in de wereld niet even gelukkig; de een heeft het harder dan de ander' (zie h. 2) - kunnen haast niet anders worden begrepen dan als provocaties op vermeende provocaties van de commissie. Hun hard-liberale stijl laat zich misschien begrijpen als de uiting van een gefrustreerde paternalistische stijl. Een reactie op onverenigbaarheid.

Dit alles is niet bedoeld als een apologie, maar als een poging gedrag te begrijpen dat - terecht - zoveel verontwaardiging heeft veroorzaakt. Maar het ging over de vader, niet over de zonen. Als ik een gezinspsycholoog was, zou ik Petrus Regout misschien postuum verwijten dat hij weliswaar een vader voor zijn arbeiders is geweest, maar niet voor zijn kinderen. Goed $^{2}$ opgevoedle kinderen zeggen en doen zoiets niet, ook niet al zouden ze zijn getart.

Men kan het zó zien: stijl is uitdrukking; beheersing (en behoud) onderdrukking. Dat geeft een mooi contrast. Als je plausibel kan maken dat ook in het uitoefenen van repressie expressie wordt gelegd, heb je bovendien een krachtig retorisch argument: als het dáár al zo is, moet het overal zo zijn - dan is "stijl" ook een onmisbaar concept in de bestudering van moderne organisaties.

Dit esthetisch motief en dit retorisch motief hebben meegespeeld bovenop de argumenten voor de keuze voor het kembegrip 'stijl', ontwikkeld in h. 4. Ik hoop dat 'stijl' een waardevolle aanvulling kan zijn op het concept 'cultuur", dat, toegepast op organisaties, al meer dan een decennium in het brandpunt van de aandacht staat. In veel definities van 'cultuur' wordt de nadruk gellegd op wat een groep, organisatie of land gemeenschappelijk heeft: gedeelde waarden, gedeelde praktijken. Zie de 'handboek'-definitie en de definities van Clifford Geertz en Geert Hofstede in hoofdstuk $4 .^{3}$ Daarom vind ik het begrip culturur bij de kenschetsing van waarden en praktijken van fabrikanten in vroeg-industriële organisaties minder geschikt dan stijl, dat méér persoonsgebonden is. Door het 'gedeelde' karakter van cultuur wordt er, bij de beschrijving van het vroeg-

2 Dat wil hier zeggen: in overeenstemming met de waarden die Petrus Regout, bijvoorbeeld in geschrifte, heeft uitgedragen en verdedigd.

${ }^{3}$ Op een andere plaats spreekt Hofstede over 'cultuur' als '[..] shared mental software [...]' (1991: 18). Vergelijk ook de definitie van organisatiecultuur van de Amerikaanse organisatiedeskundige Edgar H. Schein: "A pattern of basic assumptions - invented, discovered, or developed by a given group as it learns to cope with its problems of external adaption and internal integration - that has worked well enough to be considered valid and therefore, to be taught new members as the correct way to perceive, think and feel in relation to those problems' (1985: 9). 
moderne fabriekssysteem, te veel gelijkgezindheid en harmonie gesuggereerd. Uitzonderingen daargelaten was die er tussen fabrikanten en arbeiders niet. (Evenmin, vermoed ik, tussen arbeiders onderling.)

Ondanks belangentegenstellingen in hedendaagse naties, organisaties en groepen is het vaak mogelijk dominante, gelijkgerichte waarden te herkennen. Daarom kan met 'nationale cultuur', 'organisatiecultuur' en '(sub)groepscultuur' genoeg vruchtbaar werk worden verricht." Als daarentegen deze samenlevingsverbanden bijeen worden gehouden door een extreme hoge machtsongelijkheid ${ }^{5}$ - zoals in dictatoriale naties met een etnisch, religieus of politiek pluriforme bevolking, in sektarische groepen waar geen afwijkende meningen binnen de groep worden getolereerd, of in fabrieksregimes in de beginjaren van de Industriële Revolutie - lijkt het woord 'cultuur' voldoende verklarende kracht te missen en, bovendien, enigszins misplaatst te zijn. Het is een kwestie van smaak. ${ }^{6}$

Differentiatie naar sterke en zwakke (ofwel homogene en heterogene) (organisatie-) culturen (vgl. Peters \& Waterman, 1982) kan mij niet doen verzoenen met het begrip bij beschrijuing van extreem ongelijke samenlevingsverbanden. Door culturele differentiatie en segmentatie te beschouwen als kenmerken van een 'zwakke cultuur' (vgl. Kunst et al., 1992) wordt het morele, functionalistische karakter van deze opvatting van cultuur slechts onderstreept. ${ }^{7}$

Een andere reden om aan stijl de voorkeur te geven boven cultuur is als men een methodologisch-individualistisch perspectief hanteert. Als ik naar (achttiende- en negentiende-eeuwse Westeuropese) fabrikanten heb gekeken, was dat niet zozeer als groep, of netwerk, of klasse, maar eerder als aggregatie van individuele beslissers. ${ }^{8}$ Daarom is stijl hier adequater.

4 Ook de concepten 'beroepscultuur' en 'sectorcultuur' zijn interessante, zij het nog weinig toegepaste instrumenten. Een pluriforme industrie als de aardewerkindustrie zou een boeiend onderzoeksgebied kunnen vormen om de verhelderende en verklarende kracht van deze concepten te testen.

5 ..die doorgaans nauw samenhangt met incompatibele waardensystemen.

${ }^{6}$ Het zou overigens interessant zijn te onderzoeken of liberale en paternalistische beheersstijlen verschillende vormen van zich-drukken ('shirking'), tegenwerking, protesten en sabotage begunstigen of oproepen.

z Zo zal het wel een beleidsrelevante' vraag zijn zich af te vragen hoe zwaar de last weegt van een verleden met een 'zwakke' organisatiecultuur.

${ }^{8}$ De tegenpartij op de werkvloer is hier grotendeels in het donker gebleven. Dat is geen gebrek aan belangstelling; ook geen politieke keuze. Ideaal bezien zouden aan de waarden, praktijken en stijlen van zowel fabrikanten als arbeiders evenredige aandacht moeten worden geschonken, vooral in thun botsingen en verwevenheid. In deze studie hebben twee problemen dat in de weg gestaan: i) gebrek aan ruimte en tijd en ii) juist het feit dat arbeiders zich al in het donker 
Cultuur is immers groepsgebonden; stijl persoonsgebonden.

'Stijl' biedt een betere aansluiting bij het dominante economische perspectief, waarin het kiezend (of beslissend) individu het uitgangspunt (ofwel: formeel object) vormt. Door tevens de 'achtergronden' van patronen in keuzes en beslissingen in het beeld te betrekken en de institutionele context waarbinnen dat gebeurt, wordt ook aan het sociologische perspectief recht gedaan. Het is ook via de achtergrond (of: waarden) en de institutionele context dat, met name, nationale cultuurkenmerken, zo gezegd, hun weg naar de 'stijl' van de individuele industriële entrepreneur vinden. Nationale waarden worden immers via het gezin, de buurt en de school in de leden van de betreffende natie geïnternaliseerd (Hofstede, 1991: 182) en doen zich bovendien via de omweg van andere instituties (politiekebestuurlijke, sociaal-economische enz.) nogmaals gevoelen.

Een vorm van legitimering van gedane arbeid is te verwijzen naar de mogelijkheden en nieuwe wegen die ermee worden gecreëerd. Dat is hierboven geprobeerd. Een andere vorm van legitimering is rechtvaardiging proberen te vinden voor bepaalde gemaakte keuzen. I k heb in deze studie ook de nadruk gelegd op ambiguiteiten. Daaraan is mijn culturele ideaal mede debet. Ik hoop vooral op onzekerheidsvermijding laag te scoren. Dat zou immers ook kunnen betekenen dat mijn tolerantie voor ambiguiteit me alert heeft gemaakt voor ambiguitteiten.

Aandacht voor ambiguiteiten zie ik als een weg die leidt naar zicht op subtiliteiten. Wie ideaaltypen construeert en vervolgens aan de hand van een aantal voorbeelden duidelijk gemaakt dat er heel wat ambiguiteit zichtbaar wordt bij een confrontatie met de historische werkelijkheid van een concreet geval, kan het best mogelijke begrip van de zaak krijgen. Het lijkt mij van alle sociaal-wetenschappelijke wegen nog de best begaanbare te zijn - al lijkt hij erg lang.

Net als in de kunst kan men in de wetenschappen slechts effect en inzicht bewerkstelligen via een omweg. De methode van de omweg - via ideaaltypen naar ambiguiteiten en zo tot subtiele inzichten - levert inzichten op die langs de direkte weg (hoe die ook mag lopen) niet kunnen worden bereikt.

Antwoorden op vragen die via een omweg worden gesteld luiden ja noch nee. Het resultaat is iets tussen verifiëren en falsificiëren in. Onderzoek-via-een-omweg betekent: door toetsing aan de empirie onbekende en onvermoede subtiele aspecten en inzichten (Clifford Geertz' 'dikke kennis') ontlokken.

bevonden. Pas rond 1885 komen ze, achter de socialistische banier, voorzichtig te voorschijn. 
Maar terug naar de bevindingen. In éên - zeer onsubtiele - zin: Petrus Regout was een paternalistisch fabrikant. Zijn claim dat hij "vader, raadgever en beschermer" ${ }^{9}$ was, zullen velen overdreven vinden, maar het verwijst wèl naar zijn stijl van werven, behouden en beheersen van arbeid.

Petrus Regout was een paternalistisch fabrikant. Niemand is hem daarvoor dank verschuldigd - al zeker geen kinderlijke dank. Een paternalistische stijl leverde ook geld op. Niet-monetaire prikkels hadden positieve financiële consequenties. Evenals veel Franse en Belgische fabrikanten heeft Petrus Regout, conform zijn opvoeding en zijn latere (door economische belangen gestuurde) oriëntatie, de stijlruimte die hij had op paternalistische wijze ingevuld. Niet meer dan dat, niet minder dan dat. Maar het is goed om te weten.

9 'Père, conseiller et protecteur' (Abum dedié à mes Enfants et mes Amis, Regout, 1866). 



\section{LITERATUUR}

Aerts, Erik, Claude Beaud \& Jean Stengers, Liberalism and Patemalism in the 19 th century, (Proceedings Tenth International Economic History Congress, Leuven, August 1990), Leuven: Leuven University Press, 1990;

Archief Petrus Regout, Contractenboek, inv. nr. 26, pp. 118-20, 122-4, 214, 309;

Argyris, Chris, Integrating the Individual and the Organization, New York: Wiley, 1964;

Baasch, Ernst, Hollündische Wirtschaftsgeschichte, Jena: Fischer, 1927;

Baudet, H., 'De dadels van Hassan en de start der Nederlandse industrialiteit', in: Wieringa, W.J., Bedrijf en samenleving: economisch-historische studies over Nederland in de negentiende en twintigste eeuw aangeboden aan prof. dr. I.J. Brugmans, Alphen a/d Rijn: Samson, 1967;

Beaud, Michel, A History of Capitalism 1500 - 1980, New York: Monthly Review Press, 1983;

Bekaert, G., Mensen wonen', Omtrent Wonen, Studiecentrum voor Ekonomisch en Sociaal Onderzoek, Antwerpen, 1975;

Bendix, Reinhard, Work and authority in industry. Ideologies of management in the course of industrialization. New York: Harper and Row, 1963 (1956);

Blok, Anton, Wittgenstein en Elias. Een methodische richtlijn voor de antropologie, Amsterdam: Polak \& Van Gennep, 1976;

Blok, Anton, 'Primitief en geciviliseerd', Sociologische Gids, jrg. 29, 1982, nrs. 3-4, pp. 197-209;

Blumer, Herbert, Symbolic Interactionism. Perspective and Method, Englewood Cliffs, New Jersey: Prentice Hall, 1969;

Bos, Nick, De "deftige lui". Elites in Maastricht tussen 1850 en 1890', Tijdschrift voor Sociale Geschiedenis, jrg. 12, nr. 1 (febr. 1986), pp. 53-89;

Bos, R.W.J.M., "Factorprijzen, technologie en marktstructurur; de groei van de Nederlandse volkshuishouding 1815-1914', AAG-Bijdragen, jrg. 22, 1979;

Bosch, Dick van den, 'Aristocratische levensvormen' De Gids, jrg. 142, 1975, nr. 5, pp. 327-50;

Bouman, P.J., Van Vroeg tot Modern Kapitalisme, J. en A. Romein (red.), De Lage Landen bij de Zee, Utrecht: De Haan, 1955 (3e druk);

Bourdieu, Pierre \& Monique de Saint-Martin, Le Patronat', Actes de la Recherche en Sciences Sociales, nr. 20-21 (maart-april), 1978, pp. 3-82;

Braverman, Harry, Labor and Monopoly Capital. The Degradation of Work in the Twentieth Century, New York: Monthly Review Press, 1974;

Briavoinne, Natalis de, 'Sur les Inventions et Perfectionnements dans l'Industrie", Académie Royale de Belgique, Mérnoires Couronnés 13 (1838), pp. 5-187; 
Brom, Gerard, Herleving van de kerkelijke kunst in katholiek Nederland, Ars catholica, Leiden, 1933;

Brown, David \& Michael J. Harrison, A Sociology of Industrialisation, Londen: The Macmillan Press, 1978;

Bruckner, C., Aachen und seine Tuchindustrie, Horb am Neckar, 1949;

Brugmans, I.J., (ed.), Statistieken van de Nederlandsche Nijuerheid wit de Eerste Helft wan de Negentiende Eeuw, 2 dln, Den Haag: Martinus Nijhoff, 1.956;

Brugmans, IJ., Paardenkracht en mensenmacht: Social-economische geschiedenis van Nederland 1795-1940, 's Gravenhage: Nijhoff, 1961;

Brugmans, Prof. Dr. IJ., De arbeidende klasse in Nederland in de $19 \mathrm{e}$ eeutw 1813-1870, Utrecht/Antwerpen: Uitgeverij Het Spectrum, 1975 (1925);

Bruland, K., 'Say's Law and the Single-Factor Explanation of British Industrialisation: A Comment', Joumal of European Economic History. 14, No. 1, 1985, pp. 187-91;

Buist, M.G., 'Banken en de industriële revolutie', in: H. Baudet \& $\mathrm{H}$. van der Meulen (red.), Kermproblemen der economische geschiedenis, Groningen: Wolters-Noordhoff, 1978, pp. 215-27;

Burrell, Gibson, No Accounting for Sexuality', Accounting, Organizations and Society, vol. 12, nr. 1, 1987, pp. 89-101;

Camijn, A.J.W., Een eeuw vol bedrijvigheid: de industrialisatie van Nederland, 1814-1914, Utrecht: Veen, 1987;

Castermans, A., Parallele des maisons de Bruxelles et des principales villes de la Belgique, construits depuis 1830 jusqu'a nos jours, Parijs/Luik, z.j. (ca. 1865);

Caulier-Mathy, N., La Modernisation des Charbonnages Liegeois pendant la Prennière Moitié du 19 e Siècle, Parijs: Société d'Edition les Belles Lettres, 1971:

Chambon, R., L'Histoire de la Verrerie en Belgique du lle Siecle à nos Jours, Brussel: Editions de la Librairie Encyclopédique, S.P.R.L., 1955;

Chandler, Alfred. D. Ir., The Visible Hand. The Managerial Revolution in American Business, Cambridge, Massachusetts: Harvard University Press, 1977;

Chapman, Stanley D., The early factory masters. The transition to the factory system in the Midlands textile industry, Newton Abbot: David \& Charles, 1967;

Child, John, "Strategies of Control and Organizational Behavior", Administrative Science Quarterly, jrg. 8 (maart 1973), pp. 1-17;

Child, John, Organization: A Guide to problems and practice, Londen: Harper and Row, 1984;

Clemens, G.H., Herinneringen en ontmoetingen. Nieuwe schetsen uit Noord-Braband, Limburg en België, Nijmegen, 1840;

Clough, Shepard B. \& Richard T. Rapp, European Economic History, Londen: McGraw-Hill, 1975 (3e editie); 
Commissie van Economische Deskundigen, Rapport arbeidsmarkfflexibiliteit en werkloosheid, 's-Gravenhage: SER, 1987;

Coppejans-Desmedt, Hilda, "Economische Opbloei in de Zuidelijke Nederlanden", Algemene Geschiedenis der Nederlanden (ed. van Houtte), v1. 8, Utrecht: De Haan, 1955, pp. 261-86;

Coriat, Benjamin, De werkplaats en de stopwatch. Over taylorisme, fordisme en massaproduktie, Amsterdam: Van Gennep, 1981 (vert. uit het frans, 1979);

Cornips, 50 jaar bouwvereniging St. Servatius Manstricht 1902-1952, Maastricht, z.j. (1952);

Courrier de la Meuse, 16-6-1866;

Dahrendorf, Ralf, On Britain, Londen: BBC, 1982;

Demoulin, R., Guillaume ler et la Transformation Economique des Provinces Belges, Liège: Faculté de Philosophie et lettres, 1938;

Dhondt, J., Notes sur les Ouvriers Industriels Gantois à I'Epoque Française', Revue du Nord, jrg. 36, 1954;

Dillen, J.G. van, 'Omstandigheden en psychische factoren in de economische geschiedenis van Nederland", in: Dillen, J.G. van, Mensen en achtergronden, Groningen: Wolters, 1964, pp. 53-79;

d'Iribarne, Phillipe, La logique de lhonneur: Gestion des entreprises et traditions nationales, Parijs: Editions du Seuil, 1989;

Doorn, J.J.A. van, Woningtoestanden te Maastricht. Een sociografische studie, onuitgegeven manuscript, 1945a;

Doorn, II.A., Het nieuwe Tricht. Schets ener economische geschiedenis vam Maastricht van 1815 tot 1940, 1945, onuitgegeven manuscript, 1945b;

Doorn, J.A.A. van, 'De economische geest te Maastricht. Een sociografische studie', Mensch en Maatschappij, jrg. 22, 1947, nr. 1, pp. 1-12 \& nr. 2, pp. 74-96;

Doorn, J.A.A. van Doorn \& C.J. Lammers, Modeme sociologie, Utrecht/Antwerpen: Het Spectrum, 1984 (1959);

Douma, Sytse \& Hein Schreuder, Economic approaches to organizations, London: Prentice Hall, 1991

Durkheim, Emile, The division of Labour in Society, Londen: MacMillan, 1984 (vert. uit het frans, 1893);

Economisch Archief wan Nederland en Koloniën, N.V., N.V. Kristal-, Glas- en Aardewerkfabrieken 'De Sphinx' $v / \mathrm{h}$ Petrus Regout \& Co. Maastricht', Amsterdam: N.V. Drukkerij Plantijn, z.p., z.j. (1936), ongepagineerd, overdruk wit -;

Economisch-en Sociaal-Historisch Jaarboek 44, Pre-moderne industrialisering in de Nederlanden vanaf de late middeleeuwen tot het midden van de 19e eeuw", 1981;

Edwards, Richard, Herrschaft im modernen Produktionsprozess, Frankfurt: Campus, 1981;

Eerenbeemt, H.F.J.M van den, Bedrijfskapitaal en ondernemerschap in Neder- 
land, 1800-1850, Leiden: Stenfert Kroese, 1965;

Ehrenberg, Ronald G. \& Robert S. Smith, Modern Labor Economics, Theory and Public Policy, Glenview: Scott, Foresman and Company, 1985 (2e druk);

Eisenstadt, S.N., Revolution and the Transformation of Societies, New York: The Free Press, 1978;

Elias, Norbert, Leber den Prozess der Zivilisation, Bern und München: Francke, 1969 (1939);

Enquete De Vries Robbé, Rapport der commissie, belast met het onderzoek naar den toestand der kinderen in fabrieken arbeidende, 1860;

Faber, J.A., De achttiende eeuw', in: J.H. van Stuijvenberg (ed), De economische geschiedenis van Nederland, Groningen: Wolters-Noordhoff, 1977;

Fischer, E.J., Fabriqueurs en fabrikanten. De Twentse katoennijuerheid en de onderneming S.J. Spanjaard te Borne tussen circa 1800 en 1930" Utrecht: Matrijs, 1983;

Flamholtz, E.G., T.K. Das \& A.S. Tsui, 'Toward an integrative framework of organizational control', Accounting, Organization and Society, vol. 10, 1985, nr. 1, pp. 35-50;

Fombrun, Charles J., "Corporate culture and competitive strategy", in: Fombrun et al., Strategic Human Recource Management, New York: Wiley, 1984;

Foucault, M., Surveiller et punir: naissance de la prison, Parijs: Gallimard, 1975;

Franke, B.H.V.A. \& W.A.C. Whitlau, De Vennootschap Nederland, Deventer: Kluwer, 1979;

Galan, C. de \& A.J.M. van Miltenburg, Economie van de arbeid, Alphen a/d Rijn/Brussel: Samson Uitgeverij, 1985 (2e druk);

GAL-bulletin, 'Val Saint-Lambert', jrg. 6, 1987, nr. 16, pp. 8-20;

Gallie, Duncan, In search of the new working class. Automation and sacial integration within the capitalist enterprise, Cambridge: Cambridge University Press, 1978;

Gemeentelijk Archief Maastricht, inv.nr. 349, corresp. 23-2-42, no. 380 B., inv.nr. 411 , corr. 22-2-42, nr. $259 \mathrm{~B}$;

Gatz, Erwin, Kirche und Krankenpflege im 19. Jahrhundert, München, 1971;

Geerts, prof. dr. G. \& dr. H. Heestermans, Groot Woordenboek der Nederlandse Taal, lle herziene druk, Utrecht/Antwerpen: Van Dale Lexicografie, 1984;

Geertz, Clifford, The Interpretation of Cultures, New York: Basic Books, 1973;

Gemeentelijk Archief Maastricht, Gemeentebestuur, correspondentie band I, Volkshuisvesting, d.d. 19-4-1864;

Geurts, A.J., 'Historische aspecten van de provincie(s) Limburg, 1815-1848', De Maasgouw, jrg. 105, 1986, nr. 2, pp. 49-78;

Giddens, Anthony, Capitalism and modern social theory, Cambridge: Cam- 
bridge University Press, 1971;

Giddens, Anthony, Nieutwe regels voor de sociologische methode, Baarn: Ambo, 1979;

Giele, J., (red.), Een kwaad leven, deel 2: Maastricht, Nijmegen: Link, 1981;

Ginzburg, C." Morelli, Freud and Sherlock Holmes. Clues and Scientific Method", History Workshop. A Journal of Sacialist Historians, nr. 9 (lente 1980), pp. 5-36;

Ginzburg ${ }_{r}$ Carlo, Omweg als methade: essays over verborgen geschiedenis, kunst en maatschappelijke herinnering, Nijmegen: SUN, 1988;

Gobert, Theadore, Liège à travers les ages. Les rues de Liège, Brussel: Editions culture et Civilisation, 1976 (deel 4), pp. 212-15;

Goffman, Erving, The Presentation of Self in Everyday Life, New York: Anchor Books, 1959;

Goffman, Erving, Asylums: Essays on the Social Situation of Mental Patients and Other Inmates, Chigago: Aldine, 1961;

Gordon, David M., 'Liberalism, paternalism and immigrant workers: foreign labour and industrial capitalism in late nineteenth century France', in: Aerts et al., 1990, pp. 40-9;

Goudsblom, Johan, Balans van de sociologie, Utrecht: Het Spectrum, 1974 (2e druk: 1984);

Goudswaard, N.B., Viffenzestig jaren nijuerheidsonderwijs, Assen: Van Gorcum, 1981;

Gouldner, Alvin W., 'Romantiek en Classicisme: Dieptestructuren in de Sociale Wetenschappen', De Gids, jrg. 136, 1973, nr. 1, pp. 3-29;

Griffiths, R.T., Industrial Retardation in the Netherlands 1830-1850, Den Haag: Nijhoff, 1979;

Griffiths, R.T., Achter, achterlijk of anders: aspecten wan de economische ontwikkeling van Nederland in de negentiende eeuw, Amsterdam: Vrije Universiteit, 1980;

Groot, A.D. de, Methodologie: Grondslagen van Onderzoek en Denken in de Gedragswetenschappen, Den Haag: Mouton \& Co, 1961;

Grumbkow, I. von, Beloning in organisaties, Deventer: Kluwer, 1982;

Gubin, Eliane, Libéralisme économique et paternalisme en Belgique au XIXe siècle', in: Aerts et al., 1990, pp. 82-93;

Hammond, J.L. \& Barbara Hammond, The town labourer, vol. 1, London: Guild Books, 1957;

Hannah, Leslie, 'Entrepreneurs and the Social Sciences', Economica, jrg. 51, 1984, pp. 219-34;

Hartwell, R.M., The causes of the Industrial Revolution in England, Londen: Methun, 1977 (1967);

Hauptoersammlung des Vereins Deutscher Ingenieure, Festschrift no. 36, Aken, 1895;

Hayakawa, S.I., Language in Thought and Action, New York: Harcourt Brace Jovanovich, 1972 (3e druk); 
Hayek, F.A. (red), Capitalism and the Historians, Chicago: University of Chicago Press, 1963 (1954);

Henderson, W. O., Britain and Industrial Europe 1750-1870, Leicester: Leicester University Press, 1965 (1954);

Herzberg, F., 'One More Time: How Do You Motivate Employees?', Harvard Business Review, jrg. 46, 1968, pp 53-62;

Hofstede, Geert, De geschiedenis wan een sociale uitvinding', in: Hofstede, Geert (red.), De toekomst wan ons werk. Een bundel opstellen over het evenwicht tussen vrijheid en gelijkheid, Leiden: Stenfert Kroese, 1978, pp. 11-29;

Hofstede, G. \& L.A. de Bettignies, 'De Werkgemeenschap "Boimondau", Mens en Onderneming, jrg. 28, 1974, nr. 6, pp. 317-38;

Hofstede, G., Culture's Consequences: Intemational Differences in Work-related Values, Beverley-Hills: Sage, 1980;

Hofstede, Geert, 'National Cultures and Organizational Cultures', The Finnish Joumal of Business Economics, nr. 1, 1985, pp. 1-19;

Hofstede, Geert, Cultures and Organizations: Software of the mind, Londen: McGraw-Hill, 1991;

Hofstede, G.H., 'Edgar H. Schein. Organizational Culture and Leadership: A Dynamic View", Organization Studies, jrg. 7, 1986, nr. 2, pp. 199-200;

Hofstede, G.H., Dutch Culture's Consequences: Health, Law, and Economy, Research Memorandum, Faculteit der Economische Wetenschappen, Rijksuniversiteit Limburg, nr. 87-037, 1987;

Horringa, D., Leiderschap en arganisatie in de onderneming, Assen: Van Grocum, 1969 (3e druk);

Hughes, Jonathan, Industrialization and Economic History: Theses and Conjectures, New York: McGraw-Hill, 1970;

Inkster, Ian, "Britain and the Single Factor thesis Once More - a Comment on Kristine Bruland', Journal of European Economic History, 17, No. 1, 1988, pp. 185-86;

Inventaris van het cultuurbezit in België, Architectuur (deel $4 n b$ N-O Stad Gent), Gent: Snoeck-Ducaju \& Zoon NV, 1975;

Iterson, Ad van, 'De vader van de porcelleinkast', Propria Cures, jrg. 90, 1980, nr. 16/17, pp. 20-1;

Iterson, Ad van, 'Cases and contexts', Working Paper RL, 87-007, Rijksuniversiteit Limburg, 1987;

Iterson, Ad van, "Woningbouw als paternalistische praktijk: ambigue motieven en legitimeringen", Working Paper RL, 87-025, Rijksuniversiteit Limburg, 1987;

Iterson, Ad van, bespreking van Gillian Wagner's The Chocolate Conscience, Vrij Nederland Boekenbijlage, 12-3-1988;

Iterson, Ad van, 'Beheersing van arbeid', Working Paper RL, 89-021, Rijksuniversiteit Limburg, 1989;

Iterson, Ad van, 'Eén ei is géén ei. Over de reikwijdte van gevalsstudies', 
ongepubliceerd manuscript, 1990;

Iterson, Ad van \& René Olie, The Dutch Business System: discretion and consenus', in: Whitley, Richard D. et al., The Sacial Foundations of Enterprise, Londen: Sage, 1992;

Janlus, H., Zur Geschichte der Aachener Juden, Aken, 1924;

Jansen, J.C.G.M., 'Maastricht tussen 1813 en 1850' in: Bijdragen en medede-

lingen betreffende de Geschiedenis der Nederlanden, deel 101, 1986. pp.

529-50;

Jappe Alberts, W., Geschiedenis van beide Limburgen, ( 2 delen), Assen: Van Gorcum, 1974;

Jonge, J.A. de, "The role of outer provinces in the process of Dutch economic growth in the nineteenth century', in: Britain and the Netherlands, deel IV, 's-Gravenhage, 1971;

Jonge, J.A. de, De industrialisatie in Nederland tussen 1850 en 1914, Nijmegen: SUN, 1976 (1968);

Joyce, Patrick, Work, Society and Politics: The culture of the factory in late Victorian England, 1980;

Kastelein, T.J., Groei naar een industriële samenleving, Groningen: WoltersNoordhoff, 1977;

Kemp, Tom, Industrialization in nineteenth century Europe, Londen: Longman, 1985 (2e editie);

Kent, Sexton \& Vesper, eds., Encyclopedia of Entrepreneurship, Englewood Cliffs, New Yersey: Prentice Hall, 1982;

Kerr, Clark, John T. Dunlop, Frederick H. Harbison \& Charles A. Myers, Industrialism and Industrial Man, Cambridge: Cambridge University Press, 1961;

Klant, Dr. J.J., Spelregels voor economen, Leiden: Stenfert Kroese, 1979 (2e druk);

Klein, P.W., Traditionele Ondernemers en Economische Groei in Nederland, 1850-1914, Haarlem: de Erven F. Bohn, 1966;

Klep, P.M.M. (et al.)(red.), Wonen in het verleden 17e - 20e eeww. Economie, politiek, volkshuisvesting, cultuur en bibliografie, Amsterdam: Nederlandsch Economisch-Historisch Archief (NEHA-series III), 1987;

Kuin, P., "Progressief en conservatief in ondernemingsland", afscheidsrede Erasmus Universiteit, Rotterdam, 1979;

Kunst, $\mathbb{P}$., Romme, G., Schreuder, H., Spangenberg, J., 'Structure and Control: an Empirical Exploration", Working Paper RL, Rijksuniversiteit Limburg, 1989a;

Kunst, Paul, 'Management control', (manuscript), 1989b;

Kunst, drs P.E.J. et al., Organisatie, Leiden: Spruyt, Van Mantgem \& De Does, 1991 (deel 1);

Kuysten, A.M., Industrie en Huisvesting van hare arbeiders in Sociale Voorzorg, 1923;

Lammers, C.J., Organisaties vergelijkenderwijs, Utrecht/Antwerpen: Het 
Spectrum, 1983;

Lammers, C.J., Romein's wet van de remmende voorsporng in het licht van de organisatiesociologie, Mededelingen der Koninklijke Nederlandse Akademie van Wetenschappen, afd. Letterkunde,nieuwe reeks, deel 47, nr. 4, 1984;

Landes, David. S. (red.), The Rise of Capitalism, New York: MacMillan, 1966:

Landes, David S. The Unbound Pronetheus, Cambridge: Cambridge University Press, 1969 ;

Landes, David, Religion and enterprise: the case of the French textile industry", in: Edward C. Carter II et al., Enterprise and Entreprenews in Nineteenth and Twentieth-Century France, Baltimore: Johns Hopkins University Press, 1976, pp. 41-86;

Lang, Berel (eds.), The concept of style, Ithaca and London, Conell University Press, 1987;

Langton, John, The ecological theory of bureacracy: "The case of Josiah Wedgwood and the British pottery industry' Administrative Science Quarterly, vol. 29, 1984, pp. 330-54;

Larsen, Janne \& Majken Schultz, 'Artifacts in a Bureaucratic Monastery'. paper gepresenteerd op de $3 e$ internationale Conference on Organizational Symbolism and Corporate Culture, Milaan, 1987;

Le Patrimaine monumental de la Belgique, volume 8, Province de Liège, Arondissement de Liège, tome $2(L-V)$, Ministère de la Culture française, Liège: Solédi, 1975;

Le Patrimoine monumental de la Belgique, volume 4, Province de Hainaut, Arondissement de Mons, Ministere de la Culture framçaise, Liège: Solédi, 1975:

Leach, Edmund, Culture and Communication. The Logic by Which Symbols are Conmected, Cambridge: Cambridge University Press, 1976;

Lebrun, Pierre, Marinette Brunier, Jan Dhont en Georges Hansotte, Essai sur la révolution industrielle en Belgique 1770-1847, Bruxelles: Palais des Academies, 1981, (Tome $\mathrm{II}_{s}$ vol. 1);

Lebrun, P., Lindustrie de la laine a Verviers pendant le XVIIe s. et le debut du $X I X e s$. Contribution d létude des origines de la revolution industrielle, Luik: Facultê de Philosophie et letres, 1948;

Lejeune, Jean, Land zonder grens; Aken, Lwik, Maastricht; studie over de geschiedkundige ontwikkeling der drie steden, Brussel: Dessart, 1958;

Leleux, F., Liéoin Bauwens, Industriel Gantois, Parijs: S.E.V.P.E.N., 1969; Levy-Leboyer, Maurice, 'Innovation and Business Strategies', in: Edward C. Carter II et al., Enterprise and Entrepreneurs in Nineteenth-and Twentieth-Century France, Baltimore: Johns Hopkins University Press, 1976, pp. 41-86;

Likert, R., New Pattems of Management, New York: McGraw-Hill, 1961;

Lipset, S.M., M.A. Trow \& J.S. Coleman, Union democracy. The international 
politics of the international typographical union, Glencoe, Illinois: Free Press, 1956;

Litjens, $\mathbb{H}_{*}$, Onmaatschappelijke gezinnem: sociologisch onderzoek naar de on maatschappelijkheid te Maastricht, Assen: Van Gorcum, 1953;

Loasby, Brian J", Management economics and the theory of the firm, Economic Journal, jrg. 77, 1967, pp. 165-176;

Macfarlane, Alan, The Origins of English Individualism, Oxford: Basil Blackwell, 1978;

Macpherson, C. B., The Political Doctrine of Possessive Individualism, Oxford: Clarendon, 1962;

Maddison, Angus, Ontwikkelingsfasen zan het kapitalisme, Utrecht/Antwerpen: Het Spectrum, 1982;

Maenen, Dr. A.J.Fr., Petrus Regout 1801-1878. Een bijdrage tot de sociaaleconomische geschiedenis aan Maastricht, Nijmegen: Centrale Drukkerij, 1959;

Mantoux, Paul, The Industrial Revolution in the eighteenth century. Chicago: University of Chicago Press, 1983 (vert. uit het frans, 1905);

Marin, Gerardo \& José Miguel Salazar, Determinants of Hetero- and Autostereotypes: Distance, Level of Contact, and Socioeconomic Development in Seven Nations', Journal of Cross-Cultural Psychology, vol. 16, nr. 4, dec. 1985, pp. 403-22;

Marshall, Alfred, Industry and Trade, Londen: MacMillan \& Co, 1919;

Marx, Karl, Het Kapitaal. Een kritische beschouwing over de economie, Bussum:

De Haan, 1975 (vert. uit het duits, 1867);

McCall, Jr., Morgan W., 'Leaders and Leadership: Of Substance and Shadow", in: Hackman, J. Richard, Edward E. Lawler III \& Lyman W. Porter, Perspectives on Behavior in Organizations, New York: McGrawHill, 1983 (2e editie), pp. 476-85;

McKendrick, N., 'Josiah Wedgewood and Factory Discipline', in: David S. Landes, The Rise of Capitalism, New York: MacMillan, 1966, pp. 65-81;

McKendrick, N., Josiah Wedgewood and Cost Accounting in the Industrial Revolution' "Journal of Economic History, jrg, 33, 1973, pp. 45-67;

McNeill, William H., Plagues and Peoples, Garden City, New York: Anchor Press/Doubleday, 1976;

Meere, J.J.M. de, Economische ontwikkeling en levensstandaard in Nederland gedurende de eerste helft van de negentiende eeuw, 's-Gravenhage: Nijhoff, 1982;

Mekking, Aart, 'Petrus Regout. Een ondernemer als bouwheer', Wonen-T A/BK, 1975, nr. 1, pp. 8-28;

Mendels, F., 'Protoindustrialization: The First Phase of the Industrialization Process', Journal of Economic History, nr. 1, jrg. 32, 1972;

Merchant, K., Control in Business Organizations, Boston: Pitman, 1984;

Merton, R.K., Science, Technology, and Society in Seventeenth Century England, New York: Harper and Row, 1970; 
Mills, C. Wright, The Sociological Imagination, New York: Oxford University Press, 1959;

Mintzberg, $H_{\text {, }}$, The Structuring of Organizations, Englewood Cliffs, New Jersey: Prentice Hall, 1979;

Mintzberg, Henry, Mintzberg over Management. De Wereld van onze Orgamizaties, Amsterdam: Veen, 1991;

Mokyr, Joel, Industrialization in the Low Countries, 1795-1850, New Haven \& London: Yale University Press, 1976;

Morgan, G., P. Frost \& L. Pondy, 'Organizational Symbolism', in: Pondy, L. et al., Organizational Symbolism, Greenwich, Connecticut: JAI Press, 1983, pp. 3-35;

Morgan, Gareth, Metaphors of Organizations, Beverley Hills: Sage, 1986;

Mumford, Lewis, The city in history. Its origins, its transformations, and its prospects, Harmondsworth: Penguin, 1979 (1961);

National Biografisch Woordenboek, deel 1, 'Lieven Bauwens', Brussel: Paleis der Academieën (uitgave van de Koninklijke Vlaamse Academieën van België), 1964;

Nisbet, R.A., The Sociological Tradition, Londen: Heinemann, 1970 (1966);

Observator, (pseud. van Nafzger, R.), Uit het sociaal verleden van Maastricht', Veritas, 27-8-38;

Orbons, drs. Piet \& drs. Lou Spronck, 'Limburgers worden Nederlanders. Een moeizaam integratieproces", Publications, band 102, 1966, pp. 31 53 ;

Ouchi, Williarm G., 'A conceptual framework for the design of organizational control mechanisms', Management Science, vol. 25, 1979, pp. 833-48;

Owen, Robert, A New View of Societies, Londen: Everyman's Library, 1927 (1813);

Parsons, Talcott, The Social System, Glencoe, Illinois: Free Press, 1951;

Pels, Dick, 'Inleiding', in: Pierre Bourdieu, Opstellen over smaak, habitus en het veldbegrip, Amsterdam: Van Gennep, 1989;

Peponis, John, "The Spatial Culture of Factories', Human Relations, vol. 38, 1985, nr. 4, pp. 357-90;

Perry, Jos, Roomsche kinine tegen roode koorts. Arbeidersbeweging en katholieke kerk in Maastricht 1880-1920, Amsterdam: Van Gennep, 1983;

Peters, Thomas J. \& Richard H. Waterman, In Search of Excellence: Lessons from America's Best-Run Companies, New York: Harper and Row, 1982;

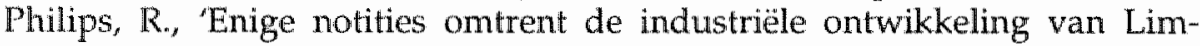
burg in de negentiende eeuw", in: Jaarboek Sociaal Historisch Centrum woor Limburg, Maastricht: SHC, (deel 1), 1955, pp. 12-6;

Pholien, Florent, Le verrerie au Pays de Liege, Luik, 1899-1900;

Pieper, Grundformen sozialer Spielregeln, Frankfurt a/M: Verlag Josef Knecht, 1931;

Poel, J.H.R. van de, Judgement and Control. Individual and Organizational Aspects of Perfomance Evaluation, Groningen: Wolters-Noordhoff, 1986; 
Poel, D.C. van de, Hoofdijnen der econonische en sociale geschiederis: sociologisch beschouwd, Utrecht, De Haan, (deel II) 1953;

Poels, H.A., 'De Noodkistrede', uitgesproken op 12 maart 1917, in: Een zestal redevoeringen. Heerlen: Uitgave Limburgse R.K. Werkliedenbond, Z.j.j;

Pollard, Sidney, The Genesis of Modem Management, Cambridge: Harvard University Press, 1965;

Popenoe, David, Sociology, Englewood Cliffs, New Yersey: Prentice Hall, 1986 (1971);

Presnell, L.S., Country Banking in the Industrial Revolution, Oxford: Oxford UP, 1956;

Pützer, Heinrich, 'Prof. Wilhelm Wickopt', Deutsche Bauzeitung (Berlijn), jrg. 42, 1908, nr. 88 (31 oktober), p. 608;

Quaedvlieg, Gerard, Het muziekleven te Maastricht in de negentiende eeww, Zutphen: De Walburg Pers, 1979;

Redfield, Robert, The Little Community. Viewpoint for the Study of a Human Whole, Chicago: The University of Chicago Press, 1955;

Regout, P., Album dédiè à mes Enfants et mes Amis, Pierre Regout à Maestricht, Parijs: Kugelmann, 1866;

Regout, J.F.E. (red.), 125 N.V. Sphinx-Céramique 100 (Gedenkboek), Maastricht: Boosten \& Stols, 1959;

Regout, Petrus, Pauperisme en Industrie. Proeve ter beantwoording van de vraag: Wat is er te doen tot verbetering van de werking der bedelaarskoloniën?, 's-Gravenhage: A. Belinfante, 1858;

Regout, Petrus, Open brief aan de Gemeenteraad van Maastricht, dd. 2-3 en 24-1863;

Regout, Petrus, Nota van den heer Regout aan de commissie belast met het onderzoek van kinderen werkende in fabrieken, 1864;

Regout, Gustaaf, Causerie de Papa ... à mes fils, dans ma 80 e année à leur usage privé, 1919;

Ricard A., Traité général du commerce an VII, II, Parijs, 1800;

Roelants du Vivier, F., 'Bois-du-Luc, une cité industrielle', La maison d'hier et d'aujourd'hui, nr. 20, dec. 1973;

Roemen, H.C.W., Maastricht. Een geografische - hoofzakelijk econowisch-geografische - beschrijoing en verklaring der agglomeraties in de Gemeente Maastricht, Maastricht-Vroenhoven 1947;

Rose, Mary B., Paternalism, industrial welfare and business strategy: Britain to $1939^{\prime}$, in: Aerts et al., 1990, pp. 115-25;

Royer De Dour, Les habitations ouvrières en Belgique. Brussel/Aken/Parijs, 1890;

Russel, Jos., De Limburgse côterie. Bijdrage tot de geschiedenis van politieke moraliteit in onze dagern. En hartelijk woord aan de Maastrichtenaren, Maastricht, 1866;

Russel, Jos., Carrière de Monsieur Pierre Regout, Maastricht, 1869; 
Schein, Edgar $\mathrm{H}_{2}$, The Role of the Founder in Creating Organizational Culture', Organizational Dynamics, 1983, pp. 13-28;

Schein, Edgar $H_{*}$, Organisational Cullure and Leadership, San Francisco: Jossey-Bass, 1985;

Schulz, Günther, 'Industrial Patriachalism in Germany', in: Aerts et al., 1990, pp 62-70;

Schumpeter, Joseph A., Theory of Economic Development: an inguiry into profits, capital, credit, interest, and the business cycle, Cambridge, Massachusetts: Harvard University Press, 1934 (1912);

Schumpeter, Joseph A., Capitalism, Socialism and Democracy, Londen: Allen \& Unwin, 1981 (1943);

Simon, Herbert A., 'Organizations and Markets', Journal of Economic Perspectives, vol. 5, nr 2, 1991, pp. 25-44;

Smelser, Neil J., Social Change in the Industrial Revolution, London: Routledge \& Kegan Paul, 1972 (4e druk) (1959);

Smets, Marcel, De ontwikkeling van de twinwijkgedachte in België. Een overzicht wan de belgische volkswoningwoningbow in de periode wan 1830 tot 1930 , Brussel: Margada, 1977;

Smit, F., 'Fabrikanten, de smaakmakers van de stedebouw', Wonen-TA/BK 42, (maart 1975), nr. 5, pp. 5-21;

Sohn-Rethel, A., Intellectual and Manual Labour, New York: MacMillan, 1978;

Sombart, W., Der moderne Kapitalismus, München: Duncker \& Humblot, 1916/1921;

Spiertz. dr. M.G., 'Limburg uit de Duitse Bond', Publications. band 102, 1966, pp. 110-18;

Spiethoff, A., 'Pure theory and economic Gestalt theory; ideal types and real types",in: F.C. Lane \& J.C. Riemersma (red.), Enterprise and secular change: readings in economic history, Londen: Allen \& Unwin, 1953;

Stanworth, M.J.K. \& J. Curran, Management Motivation in the Smaller Business, Londen: Gower Press, 1973;

Stearns, Peter N., Lives of Labour: Work in a Maturing Industrial Society, London: Croom Helm, 1975;

Stearns, Peter N., European Society in Upheawal, New York, 1976;

Steegmans, J. De Volkshuisvesting te Maustricht, (brochure; eerder verschenen in de Limburger Koerier, 30 maart, 2, 3 \& 4 april 1929);

Stichting Werkgroep Industriële Archeologie Maastricht, Société Céramique Maastricht. Een industrieel-archeologische verkenning, Maastricht: LeiterNypels, 1989 (Deelrapport 3);

Stinchcombe, A.L., 'Social structure and organizations', in: March, J. G. (red.), Handbook of Organizations, Chicago: Rand McNally, 1965;

Stuijvenberg, J.H. van, 'Economische groei in Nederland in de negentiende eeuw', in: W. Wieringa et al., Bedrijf en Samenleving; economisch-historische studies over Nederland in de negentiende en twintigste eeuw, Alphen 
aran de Rijn: Samson, 1967;

Sumner, William G., Folkways, New York: New American Library, 1960 (1906):

Swaan, Abram de, Zorg en de Staat. Amsterdam: Bert Bakker, 1989;

Thewissen, Ch. 'Het Hollandsche tijdperk te Mastricht', Publications, 1940 ;

Thompson, E.P., Time, Work-discipline, and Industrial Capitalism", Past and Present. A Joumal of Scientific History, jrg. 38, 1967, pp. 56-97;

Thompson, E.P., The making of the English working class, Harmondisworth: Penguin, 1980;

Tönnies, Ferdinand, Community and Society, Harper, 1963 (vert. uit het duits, 1887);

Trier, Eduard \& Willy Weyres, Kunst des 19. Jahmumderts im Reinland, Düsseldorf: Sclrwann, 1980 (Band 2. Architektur: II);

Ubachs, M., Een eeww modern kapitalisme. De Regouts. Leed en strija wam Maastricht's proletariaat, Nijmegen: Link, 1976 (1934);

Ubachs, P.J.H., Tweeduizend jaar Maastricht, Maastricht: Schenk, 1991;

Veblen, Thorstein, The Theory of the Leisure Class, New York: Viking Press, 1967 (1899);

Veblen, Thorstein, The Theory of Business Enterprise, New Brunswick, New Jersey: Transaction Books, 1978 (1904);

Verberme, L.G.I., Geschiedenis van Nederlamd, deel VIII, Amsterdam: Joost van den Vondel", 1938;

Verberne, L.G.J., De Nederlandse arbeidersbeweging in de negentiende eeww, Utrecht/Antwerpen: Het Spectrum, 1959 (1940);

Verhey, J.B.M., De oorzaken der industrièle Revolutiete Mastricht na 1839, (scriptie, Amsterdam, 1952);

Viviani, Mario, 'Partisans, profit and blank walls: crisis and cultural change in the cooperative company as expressed in its artifacts', paper gepresenteerd op de $3 \mathrm{e}$ internationale Conference on Organizational Symbolism and Corporate Culture, Milaan, 1987;

Voorden, W. van, Institutionalisering en arbeidsmarktbeleid, Alphen a/d Rijn: Samson Uitgeverij, 1976;

Vries, Johan de, De Economische Achteruitgang der Republiek, Amsterdam: I. van Campen, 1959;

Vroede, M. de, "Een overgangstijd", in: Algemene Geschiedenis der Nederlanden, deel 10, Haarlem: Fibula-Van Dishoeck, 1981, pp. "1- 20;

Wagner, Gilian, The chocolate conscience, Londen: Chatto \& Windus, 1987; Weber, Max, Wirtschaft und Gesellschaft, Köln-Berlin: Kiepenhever und Witsch, Studienausgabe, 1964 (1922);

Weber, Max, The protestant ethic and the spirit of capitalism, Londen: Allen \& Unwin, 1976, 2e editie (1930);

Weber, Max, 'Bureaucracy', in: Gerth, H.H. \& C. Wright Mills, From Max Weber: Essays in Sociology, New York, 1958; 
Wee, Herman van der, De Industriele Revolutie in België', in: Historische aspecten wan de Economische Groei, Antwerpen/Utrecht: De Nederlandsche Boekhandel, 1972, pp. 168-205;

Weick, Karl, The Social Psychology of Organizing, (2e ed.), Reading, Mass:: Addison-Wesley, 1979;

Westendorp Boerma, J.J., Johames wan den Bosch als sociaal herworner, Amsterdam, 1927;

Weyres, Willy \& Albrecht Mann, Handbuch zur rheinischen Baukunst des 19ten Jahrhunderts 1800-1880, Köln, 1968;

Whitley, Richard, Towards the Comparative Analysis of Business Systems', paper gepresenteerd tijdens de tiende EGOS-conferentie in Wenen, 1991:

Wieringa, W.J., Economische heroriëntering in Nederland in de Negentiende Eeuw, Groningen: J.B. Wolters, 1955;

Willems, J.G.L.M., Ondernemingen, bedrifsleven en maatschappij, Leiden: Stenfert Kroese, 1977;

Williams, Robin M., Jr., American Society: A Sociological Interpretation, New York: Knopfler, 1970 (3e druk);

Williams, Raymond, Keywords. A Vocabulary of Culture and Society, Fontana: Croom Helm, 1976;

Williamson, O.E. Markets and Hierarchies. Analysis and Antitrust Implications, New York: The Free Press, 1975;

Williamson, O., The Economic Institutions of Capitalism, New York: The Free Press, 1985

Witkin, Robert W., The collusive manoevre - a study of organisational style in work relations', paper gepresenteerd op de 3e internationale Conference on Organizational Symbolism and Corporate Culture, Milaan, 1987;

Witteloostuijn, A. van \& A. van Lier, 'Organizational Inertia, Strategic Competition and Permanent Failure', Research Memorandum, Faculteit der Economische Wetenschappen, Rijksuniversiteit Limburg, nr. 91019, 1991;

Yin, Robert K., Case Study Research, Design and Methods, Beverley Hills: Sage, 1984;

Zanden, J.L. van, 'De mythe van de achterlijkheid van de Nederlandse economie in de negentiende eeuw', Spiegel historiael, jrg. 24, 1989, pp. 163-67;

Zonneveld, Peter van, 'Tussen Waterloo en Willem II', NRC-Handelsblad, 14/11/80 (Cultureel Supplement, special over de Nederlandse culturur in de eerste helft van de $19 \mathrm{e}$ eeuw'). 


\section{SUMMARY (SAMENVATTING IN HET ENGELS)}

This dissertation is about problems of recruiting, maintaining, coordinating and disciplining labour in manufacturing industries - that is, labour management problems in a quasi-experimental setting: during the initial decades of the Industrial Revolution in Western Europe, when these problems, in this form and extent, were new, so that entrepreneurs hardly could fall back on well-tried recipes.

After an introduction on theoretical and methodological points of departure, chapter 2 offers a description (not an interpretation or explanation) of the case on which this study is built: the crystal, glass, and pottery factories of Petrus Regout in Maastricht, capital of the most southern province of the Netherlands.

Regout (1801 - 1878) was the first and for a long time the only big industrialist in the Netherlands. His parents ran an earthenware and glass retail business. Petrus entered the business at a very young age. He travelled extensively on business, especially in Wallonia, the French speaking part of the Netherlands where industrialization had begun on the Continent. However, the Belgian Revolution of 1831 put an end to Regout's trading activities. The Dutch authorities imposed a prohibition on imports from the territories in revolt. Especially for Maastricht, this proved to be a disastrous measure. In 1834, an exception on the prohibitions was granted, allowing imports of raw materials. Regout immediately decided to start polishing glass and crystal by himself. This 'make'-decision was the starting point for a series of industrial enterprises, started by Regout. Most of them proved to be very succesful.

But Petrus Regout never ceased to be a merchant. He can be considered a typical representative of 'piracy capitalism' (Thorstein Veblen). When in 1848 , the year of political uprisings in many Western European countries, an international economic crisis broke out and sales stagnated, Regout speculated that the crisis would not last long and kept on producing. He was right. When the tide turned, he could sell all his stock against profitable prices. Regout had definitely made it.

When in 1878 the 'King of the Potters' died, his factories employed 2500 workers and took up 10 hectares. At that time, Dutch industrialization was still in its infancy.

However, as to his opinion on work, workers and organization, Regout was an outright conservative, and not the cynical liberal people held (and hold) him for. With regard to the 'social' aspects of enterpreneurship he took over the strongly hierarchical, if not feudal, value system of the 
civilization in which he grew up. His life-long striving to adopt an aristocratic life-style (and his ardent wish to be recognized as such), fits in this pattern. At the end of his life a certain sentimental megalomania took possesion of him. But all this does not alter the fact that Petrus Regout was a man with considerable 'entrepreneurial talents' (qualification of Joel Mokyr).

In order to situate this entrepeneur in his economic and social context, a description of the Industrial Revolution in England, France, Germany, Belgium and the Netherlands is given in chapter 3. It is argued that Regout fits in the English pattern (alert, not-risk-averse, the enterprise as a means to achieve a certain goal) as well as in the continental pattern (inert, risk-averse, the entreprise as a goal as such). Looking at the early Belgian and the retarded Dutch industrialization, Regout (as well as his employees) must be considered a thoroughbred Belgian (e.g. Walloon) industrial entrepreneur.

In chapter 4 a theoretical model on problems of recruitment, stabilization and control of the labour force in the factory system is set forth. Pioneering entrepeneurs can be placed on two dimensions (recruitment/stabilization, on the one hand, and control, on the other) as to the weight of the difficulties they have in resolving these problems. These difficulties depend among other things on market and institutional restrictions. However loose or tight these constraints may be, there is always a certain "space" to execute a certain personal style (in this case - a style of labour management). This space not only offers opportunities, but also confronts (economic) actors with the necessity to use this space, to develope a style. Hence, the first thesis: "In order to be succesful on markets and in organizations one has to develop a style.'

In this chapter, two ideal-types of early industrial labour management styles are developed: the liberal style (emphasis on market and instrumental relations) and the paternalistic style (emphasis on enhancing authority and loyalty relations). Finally, a section is devoted to aspects of legitimation of these styles.

In chapter 5 the theoretical model is applied to the Regout enterprises. It is argued that evidence points in the direction of Regout employing mainly a paternalistic style, which seems to be congruent with the southward (again, Walloon) socio-economic orientation of his family and the town in which he grew up. As, however, the evidence is not free from a certain ambiguity, in the last three sections of this chapter I expand on three 'mini case studies', to narrow the focus and, in doing so, gain more 'thick knowledge' (Clifford Geertz) on the subject. The first two cases deal with Regout's 'Cité Ouvrière', a large, seven-storeyed tenement, where some 72 worker's families had to live. This company housing intiative cursed as 'het menschenpakhuis' (or: the warehouse for people) - is situated in the context of similar initiatives (by entrepreneurs as well as 
others) in the Low Lands. In the next section the symbolic - and therefore, legitimizing - aspects of this building are studied. Finally, Regout's publications concerning the 'social issue' are dealt with.

In the closing pages, the disputed reputation of the Regout family is discussed in the light of the theoretical and empirical perspective opened up in this dissertation. It is, rather provocatively, stated that Petrus Regout was a father for his workers, but not for his own children. 
Ad van Iterson werd op 29 januari 1952 geboren in Maastricht. In diezelfde stad voltooide hij in 1969 zijn HBS-A opleiding aan het Sint-Maartenscollege. Vervolgens studeerde hij sociologie aan de Katholieke Universiteit Nijmegen (kandidaats) en de Universiteit van Amsterdam (doctoraal). Na zijn studie was hij onder meer werkzaam aan het Sociologisch Instituut van laatstgenoemde universiteit (waar hij onderzoek deed op het gebied van de literatuursociologie), als secretaris wan prof. dr Norbert Elias en als voorlichter bij het Academisch Ziekenhuis Maastricht. Sinds december 1985 is hij werkzaam aan de Faculteit der Economische Wetenschappen, waar hij nu de functie van universitair docent bekleedt in de sectie Organisatie van de vakgroep Bedrijfseconomie. Naast zijn dissertatie-onderzoek verricht hij, samen met René Olie, onderzoek naar het Nederlandse bedrijfssysteem in een historisch perspectief ("The Dutch Business System: Discretion and Consensus", binnenkort te verschijnen in: Whitley, Richard D. et al, The Sacial Foundations of Enterprise, Sage).

Ad van Iterson was redacteur van het Amsterdams studentenweekblad Propria Cures (1979-1982). In de jaren daarna publiceerde hij verhalen, journalistieke en opiniërende artikelen in o.a. NRC Handelsblad, Hollands Maandblad, Haagse Post, Intermagazine, Avenue, Observant en Modulair. Sinds 1985 bespreekt hij regelmatig non-fictieboeken (in het bijzonder sociaalwetenschappelijke literatuur) in de boekenbijlage van Vrij Nederland.

In 1986 publiceerde hij de verhalenbundel Het geheim van de dichter (Veen) en 1990 de roman Een verborgen man (Veen). Vooral in het laatste boek is de invloed van grote bureaucratische organisaties op persoonlijke levens een belangrijk thema. Voorts schreef hij ter gelegenheid van de opening van het Theater aan het Vrijthof een gedenkboek, Het Vrijthof is een schouwtoneel (1992). Sinds 1985 heeft hij een maandelijkse column op Omroep Limburg.

Ad van Iterson is gehuwd en heeft drie dochters en een zoon. 